Enio Moraes J únior

\title{
A Formação Cidadã do J ornalista no Brasil:

\author{
Um estudo de caso \\ da formação do jornalista na USP
}

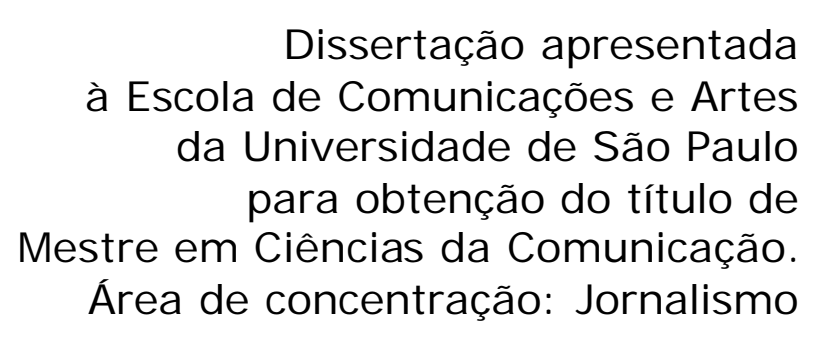

Orientador: Prof. Dr. José Coelho Sobrinho

São Paulo

2005 


\section{Ficha catalográfica:}

MORAES JÚNIOR, Enio. A Formação Cidadã do Jornalista no Brasil: um estudo de caso da formação do jornalista na USP. São Paulo, 2005. 213 f. Dissertação (Mestrado em Ciências da Comunicação). Escola de Comunicações e Artes, Universidade de São Paulo.

\section{Autorizo:}

( ) divulgação de texto completo em base de dados especializados

( ) reprodução total ou parcial, por processos

fotocopiadores, exclusivamente para fins acadêmicos e científicos.

Assinatura:

Data 
Autor: Enio Moraes J únior

A Formação Cidadã do Jornalista no Brasil: um estudo de caso da formação do jornalista na USP

Presidente da Banca:

Prof. Dr.

Banca Examinadora:

Prof. Dr. I nstituição:

Prof. Dr. Instituição:

Aprovada em:

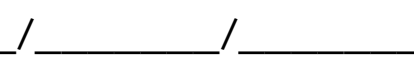




\section{Dedicatória}

Ao meu pai, Enio Moraes, inspiração política da minha cidadania;

À minha mãe, Joene Vieira Moraes, inspiração afetiva da minha cidadania. 


\section{Agradecimentos}

Aos meus pais e aos meus irmãos Enilson, Enny e Renata, pela inspiração para crescer, aprender, amadurecer e ser feliz;

Às minhas inesquecíveis avós Noêmia Marinho e Maria Pastora, pelas preces e pelo zelo;

À minha tia Joêmia Marinho, à minha prima Joseilda Pereira e a toda minha família, pela confiança;

Aos professores José Coelho Sobrinho, Amilton Gláucio, Nancy Ramadan, Elisabete Laurenti e Eugênio Bucci, pelo incentivo;

Aos funcionários Paulo César Bontempi, Tânia Magaly Aníbal, Aparecida de Fátima Souza, Olga Mendonça, Célia C. da Cruz, Carlos Augusto Soares e Ulisses Rodrigues de Paula, pela presteza;

Aos amigos e colegas da ECA Adriana Manfredini, Elvis Wanderley,

Ciça Lessa, Alexandre Barbosa, Liana Vidigal, Cássia Lobão; aos amigos de muito tempo Helena Conceição, César Ronaldo,

Cristiane Queiroz, Lícia Malta, Sérgio Luís e Zeca Oliveira; aos novos amigos Eduardo Almeida, Fabiana Oliva, Loverci Moraes, Alessandra Meleiro, Júlio Moreira, Ana Paula, Marco Antônio, Veronice Carvalho, Carla Rabelo e Roberta Rodrigues, pelo apoio;

A J oão Batista Gomes Macedo, pelo companheirismo;

Em especial a todos os meus alunos, inesgotável fonte de aprendizado. 
Dizem que os bons morrem antes. Eu jamais concordei com isso porque acho que quem é bom permanece para sempre vivo naquilo que plantou e naquilo que ensinou.

Para André Florêncio, cujos ensinamentos vivem entre nós. Obrigado por tudo. 
MORAES JÚNIOR, Enio. A Formação Cidadã do Jornalista no Brasil: um estudo de caso da formação do jornalista na USP. São Paulo, 2005. 213 f. Dissertação (Mestrado em Ciências da Comunicação). Escola de Comunicações e Artes, Universidade de São Paulo.

RESUMO: O jornalista deve ser um atento observador social e articulador de idéias. A sua formação cidadã tem um papel importante no desenvolvimento desta habilidade. Este estudo aborda de que maneira esta formação é contemplada no currículo de graduação, na relação discente - docente, na produção laboratorial e nos trabalhos de conclusão de curso tomando como referência o curso de Comunicação Social - habilitação em Jornalismo (noturno) - da Universidade de São Paulo.

Palavras-chave: Cidadania. Formação. Jornalismo. 
MORAES JÚNIOR, Enio. Brazilian journalist's citizenship education: a case study of journalist education at USP. São Paulo, 2005. $213 \mathrm{f}$. Dissertation (Master's Degree in Science of Communication). Arts and Sciences School, Sao Paulo University.

ABSTRACT: The journalist should be an attentive observer of society and the articulator of ideas. His citizen's education has an important role in developing these skills. This study discusses how this is comtemplated in undergraduate curriculums, in the relationships between teachers and students, in the laboratorial production and works of course conclusion taking as reference the Communications course - the education of journalists - as taught at the University of Sao Paulo.

Key words: Citizenship. Education. J ournalism. 
O desenvolvimento espetacular da informação, quer no que diz respeito às fontes, quer à capacidade de difusão, está gerando uma verdadeira revolução, que afeta não apenas a produção e o trabalho, mas principalmente a educação e a formação".

Moacir Gadotti (2000: 33) 


\section{Sumário}

I ntrodução

01

\section{PARTE I}

\section{Capítulo I}

Da Cidadania $\quad 07$

1.1. Da Cidadania Moderna e da Cidadania Contemporânea 12

1.2. Da Cidadania Brasileira 23

\section{Capítulo I I}

Do J ornalismo como instrumento da Cidadania 32

2.1. Do Jornalismo e da Cidadania no Brasil 40

2.2. A Ética e a Responsabilidade Social do Jornalismo 51

\section{Capítulo II I}

Da Cidadania e da Formação do J ornalista no Brasil $\quad 54$

3.1. Das Quatro etapas do Ensino de Jornalismo no Brasil $\quad 59$

3.2. Da Escola de Comunicações e Artes e do Curso de Jornalismo 67

\section{PARTE II}

\section{Capítulo IV}

Do Currículo do Curso de J ornalismo 72

4.1. Da LDB e das Diretrizes Curriculares 76

4.2. Do Currículo Ecano 78

4.3. Da Apresentação e da Análise dos Dados da Pesquisa 89

\section{Capítulo V}

Dos Discentes e da Produção Laboratorial 95

5.1. Dos Laboratórios e do Jornal do Campus 96

5.2. Da Apresentação e da Análise dos Dados da Pesquisa 98 


\section{Capítulo VI}

Dos Docentes

116

6.1. Da Apresentação e da Análise dos Dados da Pesquisa

\section{Capítulo VI I}

Dos Projetos Experimentais

7.1. Da Apresentação e da Análise dos Dados da Pesquisa

Conclusão

Bibliografia

158

\section{Apêndices}

Apêndice 01:

Relação bibliográfica dos jornais-laboratório - Jornal do Campus referenciados nesta dissertação

174

Apêndice 02:

Relação bibliográfica dos projetos experimentais do curso de Jornalismo noturno 2002 - 2003 referenciados nesta dissertação

176

\section{Anexos}

Anexo 01:

Declaração Universal dos Direitos Humanos

Anexo 02:

Código de Ética dos J ornalistas Brasileiros

Anexo 03:

Primeira página (reduzida) do Jornal do Campus - Edição 281198 Anexo 04:

Primeira página (reduzida) do Jornal do Campus - Edição 282199 
Anexo 05:

Primeira página (reduzida) do Jornal do Campus - Edição 283200 Anexo 06:

Primeira página (reduzida) do Jornal do Campus - Edição 284201 Anexo 07:

Primeira página (reduzida) do Jornal do Campus - 284/Especial 202 Anexo 08:

Primeira página (reduzida) do Jornal do Campus - Edição 285203 Anexo 09:

Primeira página (reduzida) do Jornal do Campus - Edição 286204 Anexo 10:

Carta aos docentes, encaminhada junto com questionário 205 Anexo 11:

Questionário aplicado aos docentes do curso de Jornalismo 210 


\section{Í ndice de quadros}

\section{Grade curricular do Curso}

1. Disciplinas do primeiro semestre 81

2. Disciplinas do segundo semestre 82

3. Disciplinas do terceiro semestre 83

4. Disciplinas do quarto semestre 84

5. Disciplinas do quinto semestre 85

6. Disciplinas do sexto semestre 85

7. Disciplinas do sétimo semestre 86

8. Disciplinas do oitavo semestre 87

9. Disciplina do nono semestre 87

9. Quadro de análise de dados 90

\section{Pesquisa com discentes do Curso}

1. Edição 281, São Paulo, 1ํ a 21 de abril de 2004

2. Edição 282, São Paulo, 22 de abril a 05 de maio de $2004 \quad 103$

3. Edição 283, São Paulo, 06 a 19 de maio de 2004105

4. Edição 284, São Paulo, 21 de maio a 03 de junho de 2004107

5. Caderno Especial (Parte integrante da edição 284) 109

6. Edição 285, São Paulo, 04 a 17 de junho de 2004

7. Edição 286, São Paulo, 25 de junho a 09 de julho de 2004112

\section{Pesquisa com docentes do Curso}

Quadro de apresentação e análise de dados 122

\section{Projetos experimentais}

1. Primeiro semestre de $2002 \quad 133$

2. Segundo semestre de $2002 \quad 134$

3. Primeiro semestre de $2003 \quad 135$

4. Segundo semestre de $2003 \quad 136$

5. Quadros de análise de dados 139 


\section{I ntrodução}

"Vocês precisam ler jornais. Vocês vão entender melhor o mundo e as pessoas". Talvez não fossem essas palavras, mas era esse conteúdo que repetia incansavelmente o meu professor de graduação em Jornalismo na Universidade Federal de Alagoas, em Maceió, Amilton Gláucio, quando eu estava ainda no início do curso nos anos 90.

Menos de quatro anos depois, Amilton era meu orientador de trabalho de conclusão de curso e nos tornamos amigos. Com o curso concluído, eu havia lido bastante e estava saindo da faculdade entendendo muito pouco sobre "o mundo e as pessoas". Conversei com ele sobre minha insatisfação e fui convencido de que "compreender" não significava um caminho linear, mas uma estrada cheia de curvas que precisava ser seguida com uma atenção constante e permanente. Amilton indicou-me alguns autores. Não lembro ao certo quais foram, mas entre eles estava a filósofa alemã Hannah Arendt.

Comecei a me interessar por Política e a me apaixonar por discussões que envolviam cidadania, democracia e direitos humanos. Fui fazer uma especialização em Jornalismo Político e Econômico. De alguma forma, estava cada vez mais entendendo "o mundo e as pessoas", como Amilton havia sugerido.

Pouco tempo depois fui convidado para lecionar no curso de Jornalismo da Universidade Tiradentes, em Aracaju, onde havia cursado a especialização. Foi o momento de discutir e apresentar uma noção de jornalismo inspirada na cidadania. Percebi que esse conceito influenciava não só a minha conduta de vida, mas pautava decisivamente o meu padrão de jornalismo, minha prática em sala de aula e minha relação com os meus alunos. Tornei-me professor da Universidade Federal de Sergipe, assumi a Diretoria Acadêmica do 
sindicado dos professores da instituição, e estava cada vez mais claro que a cidadania era o meu caminho para entender "o mundo e as pessoas".

Decidi torná-la tema do meu mestrado. Em São Paulo, no início deste mestrado, o professor José Coelho Sobrinho, meu orientador, falou em uma das primeiras aulas sobre um autor que eu não conhecia: Carl Rogers. Achei que aí sim, com ajuda do Coelho e do Rogers poderia ser cumprida, de fato, a promessa do Amilton e seria mais bem amarrado meu conhecimento sobre "o mundo e as pessoas". Eu estava certo.

No mestrado, recortei meu universo de "mundo e pessoas" àqueles que há mais de dez anos têm sido meus eixos: a cidadania e a formação de jornalistas. Coelho, os alunos, os professores que entrevistei para esta dissertação e outros docentes com quem conversei, ao lado de autores como Arendt, Pinsky, Chaparro, Rogers e Gadotti, mostraram-me que o que Amilton havia dito era melhor do que eu pensava. Conhecer "o mundo e as pessoas" é um trabalho constante que, assim como a cidadania, requer uma luta permanente com interesses pautados nos direitos humanos e na democracia.

Descobri que quanto mais pratico a cidadania no dia a dia, em sala de aula e no exercício do jornalismo, melhor compreendo e mais me comprometo com o mundo e com as pessoas. Esse é o caminho por que a vida me levou, esse é o caminho por que quero - hoje com mais clareza - ir, e esse é o caminho por que convido o leitor a vir comigo nas próximas páginas.

Este trabalho tem como tema a formação cidadã do jornalista e problematiza os momentos e a maneira como ela aparece e é tratada na atual formação do jornalista na USP. O recorte uspiano (e ecano) deve-se ao fato de o curso de Jornalismo da USP ocupar um espaço pioneiro no ensino da Comunicação no País e à sua notoriedade em 
produção acadêmica, constituindo, há mais de trinta anos, referência nacional e mundial para as pesquisas comunicacionais.

E mais que isso: deve-se também à peculiaridade com que a questão da alteração curricular tem sido tratada tanto por docentes quanto por discentes da instituição em disputadas e inflamadas reuniões com rica diversidade de posições e pensamentos. Assim entendemos caminhar na direção das atuais tendências dos estudos da Comunicação no Brasil, que procuram entender o jornalismo e a formação do seu profissional dentro de um processo sócio-cultural.

A partir do conceito de cidadania, destacando temas correlatos como os direitos humanos, a democracia, a ética profissional e a responsabilidade social do jornalismo, abordamos os seguintes problemas de pesquisa:

- A cidadania é contemplada na atual grade curricular do curso de Jornalismo noturno da Universidade de São Paulo?

- A partir da análise curricular, em que etapas e disciplinas esse tipo de formação acontece?

- Na visão dos professores, de que forma esses conteúdos são passados e cobrados?

- De que forma os alunos percebem trabalhar esse conteúdo teórico nas disciplinas laboratoriais?

- Como a cidadania é contemplada nos projetos experimentais?

A partir desses problemas, formulamos as seguintes hipóteses:

- Na atual grade curricular do curso de Jornalismo noturno da Universidade de São Paulo esta contemplação é precária;

- A formação cidadã ocorre, sobretudo, em etapas e disciplinas curriculares da primeira metade do curso; 
- Os conteúdos cidadãos são passados e cobrados pelos docentes de forma teórica, com pouca vinculação com a prática da atividade jornalística;

- Os alunos trabalham pouco ou percebem com pouca clareza a aplicação dos conteúdos cidadãos nas disciplinas laboratoriais;

- A cidadania é contemplada, direta ou indiretamente, nos projetos experimentais.

Esta pesquisa tem como objetivo geral caracterizar a formação dos discentes do curso de Comunicação Social, habilitação em Jornalismo (noturno) da Escola de Comunicações e Artes da Universidade de São Paulo, no sentido de explicitar disciplinas curriculares, produções laboratoriais e etapas em função da sua formação cidadã.

A presente pesquisa pretende também apontar a formação acadêmica do jornalista, especialmente no que tange ao seu caráter cidadão, como importante para o exercício diário da profissão. Além disso, o trabalho visa a contribuir no sentido de abrir espaços de atuação jornalística em que não sejam consideradas apenas as diretrizes do mercado, mas também o caráter humano e social da atividade, estimulando as escolas de Jornalismo a investirem na formação cidadã de seus alunos.

Este trabalho está dividido em duas partes. Na Parte I discutimos o que significa cidadania e abordamos o conceito na realidade brasileira (Capítulo I), em seguida, elaboramos uma reflexão sobre o jornalismo como instrumento da cidadania (Capítulo II). Por fim, discutimos a cidadania na formação do jornalista brasileiro (Capítulo III).

$\mathrm{Na}$ Parte II procuramos entender a relação entre a cidadania e a formação do jornalista uspiano em quatro momentos: no currículo (Capítulo IV), na percepção do discente, incluindo produção laboratorial 
(Capítulo V), na percepção do docente (Capítulo VI) e nos projetos experimentais (Capítulo VII).

Apensamos ao trabalho a bibliografia das edições do jornallaboratório - Jornal do Campus - produzidas pelos alunos de jornalismo da ECA e dos projetos experimentais que foram analisados ou referenciados neste estudo.

Anexamos a esta dissertação dois documentos que entendemos serem relevantes para o entendimento da cidadania no jornalismo brasileiro e que terminam por influir decisivamente na formação cidadã do profissional da área: a Declaração dos Direitos Humanos, de 1948, e o Código de Ética dos Jornalistas Brasileiros, de 1987. Além disso, anexamos ao trabalho as primeiras páginas das edições do Jornal do Campus analisadas, a carta e o questionário aplicado aos docentes da ECA por ocasião da pesquisa. 
PARTE I 


\section{CAPÍTULO I}

\section{Da Cidadania}

Todos os homens nascem livres e iguais em

dignidade e direitos. São dotados de razão e consciência e devem agir em relação uns aos outros com espírito de fraternidade.

Artigo 1

da Declaração Universal dos Direitos Humanos

Cidadania não é um conceito estanque. Ao contrário, é um conceito histórico, variando no tempo e principalmente no espaço. Embora guarde o amálgama de uma origem comum, a cidadania contemporânea tem aspectos bem específicos determinados pelos Estados-nacionais. T. H. Marshall (1967: 76), que nos anos 60 publicou um estudo até hoje freqüentemente retomado para se discutir cidadania, observa:

A cidadania é um status concedido àqueles que são membros integrais de uma comunidade. Todos aqueles que possuem o status são iguais com respeito aos direitos e obrigações. Não há nenhum princípio universal que determine o que estes direitos e obrigações serão, mas as sociedades nas quais a cidadania é uma instituição em desenvolvimento criam uma imagem de uma cidadania ideal em relação à qual o sucesso pode ser medido e em relação à qual a aspiração pode ser dirigida.

Jaime Pinsky (PINSKY; BASSANEZI, 2003: 09) observa que o conceito de Marshall, apesar de ter mais de trinta anos, ainda permanece atual:

É muito diferente ser cidadão na Alemanha, nos Estados Unidos ou no Brasil (para não falar dos países em que a palavra (cidadania) é 
tabu), não apenas pelas regras que definem quem é ou não, titular da cidadania (por direito territorial ou de sangue), mas também pelos direitos e deveres distintos que caracterizam o cidadão em cada um dos Estados-nacionais contemporâneos.

Mas as bases dos "direitos e obrigações" que originaram o que hoje concebemos como cidadania encontram-se num passado muito distante da civilização. Para Pinsky (PINSKY; BASSANEZI, 2003: 15), a cidadania dá seus primeiros sinais na história da humanidade fora do âmbito capitalista e com forte conotação religiosa (ainda que também política) na Idade Antiga (ano 4000 a.C. ao século I d.C.). Ela aparece junto ao povo hebreu, antecessores dos atuais judeus, por volta do século VIII a.C.. É no estabelecimento do chamado monoteísmo ético ${ }^{1}$, que é inaugurada uma forma de fé em que o olhar divino volta-se não apenas para cada indivíduo, mas para o grupo social.

É nessa fase que profetas como Amós (783 a 743 a.C.) e Isaías (740 a 701 a.C.) exercem forte influência sobre o povo hebreu na condição de pensadores de uma nova concepção de religião. Os rudimentos da cidadania surgem, assim, na defesa de padrões de vida mais justos nos relacionamentos humanos. Ela começa a ser produzida na noção de um deus comprometido menos com conquistas, vitórias bélicas e dominação de povos, e mais envolvido com questões como a solidariedade entre os indivíduos.

Mas é na civilização dos gregos e na dos romanos que a cidadania vai ganhar a decisiva significação que é, até hoje, uma das suas tônicas: a dimensão política. É nessa linha que, segundo Pinsky (PINSKY; BASSANEZI, 2003), Aristóteles (384-322 a.C.) vai definir cidadania como o poder de governar e o direito de ser governado.

Mas no pensamento aristotélico nem todos podem exercer 0 governo. Governar cabe apenas àqueles capazes de uma "virtude esclarecida". Assim, Aristóteles exclui do seu conceito de cidadania os

\footnotetext{
${ }^{1}$ O monoteísmo ético, nas palavras de Pinsky (PINSKY; BASSANEZI, 2003: 16), pressupõe “um deus pouco preocupado em ser objeto da idolatria das pessoas e com o sacrifício de animais imolados em seu holocausto, mas muito comprometido com problemas vinculados à exclusão social, à pobreza, à fome, à solidariedade".
} 
escravos, os artesãos e os comerciantes. Para ele, a ocupação não thes permitia tempo para participar das decisões do governo e, além disso, os trabalhos braçais embruteceriam a alma.

Tanto para Marshall quanto para Pinsky, as cidades-estados são um conceito importante para entender a noção de cidadania no contexto clássico antigo. Elas surgiram e se desenvolveram a partir de mudanças econômicas e sociais entre os séculos IX e VIII a.C., fruto de um quadro de intercâmbio de bens e idéias por toda região do Mediterrâneo. Eram núcleos agrícolas de extensões variáveis, pertencentes a proprietários que formavam associações.

Inaugurando remotamente a política e a democracia, as decisões coletivas tomadas nessas cidades estavam subordinadas a determinados grupos. Extremamente fundamentadas na experiência dos antepassados e com decisões amparadas na experiência dos mais velhos, havia também forte distinção entre jovens e velhos (os mais velhos compunham os Conselhos de Anciãos). Estes últimos gozavam de muito mais direitos que os primeiros.

Além disso, apesar de na civilização romana as mulheres gozarem de mais prestígio do que na grega, em ambas as sociedades, extremamente bélicas, elas ficavam igualmente à margem da vida pública e das decisões políticas.

No entanto, o maior conflito ocorria na hierarquia sodial. Entre os gregos, cidadão era o proprietário de terras, e apenas este. Como deixava claro o pensamento de Aristóteles, ficavam excluídos da cidadania estrangeiros, dominados e escravos.

Entre os romanos, no entanto, a cidadania foi progressivamente avançando no sentido da universalização, funcionando como instrumento de contenção e controle dos povos dominados.

Para Hannah Arendt (1987: 38-39), os limites da cidadania grega e romana podem ser entendidos não como uma forma nefasta de privilégios, mas como uma dimensão atribuída à vida pública. Desta 
última, entendida como uma extensão da vida privada, participavam apenas os que possuíssem poder (propriedades, escravos, lar etc.):

(...) a antiga santidade do lar, mais pronunciada na Grécia clássica que em Roma antiga, jamais foi inteiramente esquecida. $O$ que impediu que a polis violasse as vidas privadas dos seus cidadãos e fez ver como sagrados os limites que cercavam cada propriedade não foi o respeito pela propriedade privada tal como a concebemos, mas o fato de que, sem ser dono de sua casa, o homem não podia participar dos negócios do mundo porque não tinha nele algum lugar que the pertencesse.

Se a civilização grega deixa à humanidade o princípio de uma cidadania como expressão de vida civil (ainda que nunca tenha sido absolutamente includente), o povo romano estimulou não só a participação na vida política, mas trouxe também avanços sociais. É especialmente no fim da República (31 a.C.) que se consolidam as contribuições da cidadania com a afirmação do Direito Romano e da oratória (PINSKY; BASSANEZI, 2003: 62):

O período tardio da República romana (...) testemunhou um grande avanço nas possibilidades de iniciativas jurídicas dos cidadãos. A implantação de cortes com jurados e do voto secreto na assembléia garantiram voz ao cidadão em geral e explica, também, a importância da oratória. Do êxito dos discursos dependiam as decisões nas reuniões populares. Isso permitiu que se adotassem medidas contrárias aos interesses aristocráticos. Várias formas de ação coletiva faziam parte da justiça popular, como o uso da sanção moral coletiva de modo a coagir o acusado de alguma ofensa a se comportar conforme os desejos da população.

No período final da Idade Antiga, a cidadania acompanha de perto a propagação do Cristianismo. Segundo Eduardo Hoonaert (PINSKY; BASSANEZI, 2003: 81-82), a intenção de levar esperança e justiça aos pobres e excluídos faz com que se desenvolva, à revelia do Império Romano, uma corrente que vai difundir, em boa parte da Europa e além dela, a fé cristã.

Nos primeiros séculos da Idade Média (séculos III a XIII d.C.), as sociedades feudais significam uma estagnação não apenas para a cidadania como também para outros aspectos da vida urbana e social. Se 
na Antiguidade a cidadania garantia aos cidadãos, inicialmente apenas proprietários e depois membros do povo, o direito à expressão política, nas sociedades medievais, os servos e os camponeses não tinham arbítrio sobre sua vida nem sobre seu destino.

Merecem menção, no final desse período, quando se dá o crescimento das cidades e a intensificação do comércio - e, conseqüentemente, um maior debate nas universidades - os estudos de Santo Tomás de Aquino (1225-1274).

Preocupado com a questão da natureza e da legitimidade do poder da monarquia e dos seus governantes, Tomás "considera que o homem só encontra realização na cidade, e o plano político é a instância possível em que o governo não-tirânico pode aliar ordem e justiça na busca do bem comum" (ARANHA; MARTINS, 1995: 201).

Ao refletir sobre esse 'bem comum', Tomás vai tocar sutilmente na questão dos direitos humanos, um ponto discutido, a rigor, apenas na I dade Moderna. Giovanni Reale e Dario Antiseri (2003: 228) ilustram bem a questão ao falar sobre o entendimento de Santo Tomás de Aquino a respeito da lei humana (a lei jurídica; 'feita pelo homem'):

A coerção exercida pela lei humana (...) tem a função de tornar possível a convivência pacífica entre os homens, embora para santo Tomás ela tenha também função pedagógica. A lei humana, portanto, pressupõe homens imperfeitos. E como ela não reprime todos os vícios, mas somente os "que prejudicam os outros" e que, como "os homicídios, os furtos etc.", "ameaçam a conservação da sociedade humana", da mesma forma "não se precisa ordenar todos os atos virtuosos, mas somente aqueles que são necessários ao bem comum". 


\title{
1.1 Da Cidadania Moderna e da Cidadania Contemporânea
}

É na Idade Moderna (séculos XIII a XVIII), quando acontece o fortalecimento dos Estados-nação, que a cidadania ganha os contornos com os quais a conhecemos hoje, baseada nos direitos humanos e na democracia. Pinsky observa (PINSKY; BASSANEZI, 2003: 10):

\begin{abstract}
A cidadania instaura-se a partir dos processos de lutas que culminaram na Declaração dos Direitos Humanos, dos Estados Unidos da América do Norte, e na Revolução Francesa. Esses dois eventos romperam o princípio de legitimidade que vigia até então, baseado nos deveres dos súditos, e passaram a estruturá-lo a partir dos direitos do cidadão. Desse momento em diante todos os tipos de luta foram travados para que se ampliasse o conceito e a prática de cidadania e o mundo ocidental o estendesse para mulheres, crianças, minorias nacionais, étnicas, sexuais, etárias. Nesse sentido, pode-se afirmar que, na sua acepção mais ampla, cidadania é expressão concerta do exercício da democracia.
\end{abstract}

O Renascimento, entre os séculos XIV e XVI, é especialmente um momento fértil para o desenvolvimento da cidadania em suas dimensões sociais, políticas e culturais na medida em que recupera as referências da Antiguidade, voltando as atenções para pensadores e filósofos grecoromanos como Sócrates, Platão e Aristóteles.

Além disso, novas concepções de sociedade e regras de relacionamento humano começam a ganhar corpo na nova sociedade. $\mathrm{O}$ homem não é mais objeto de vontades que the são exteriores (ou divinas), mas sujeito da história. A obra A Utopia, de Thomas Morus (1478-1535), representa bem a imagem de um homem menos servil a uma divindade e, ao mesmo tempo, mais preocupado com o bem-estar social.

Na Idade Moderna, a cultura medieval é definitivamente substituída pelos valores da razão. O Renascimento tem uma contribuição inegável nesse processo, mas é com o lluminismo (século XVII) que o 
racionalismo ${ }^{2}$ burguês é definitivamente implantado. Todo o processo vai culminar com as revoluções burguesas que sacodem a Europa e a América a partir do século XVII e que configuram os primeiros Estadosnacionais.

A partir daí a cidadania ganha um terreno fértil para sua expressão e toma, definitivamente, os contornos com os qua is hoje a conhecemos. Como princípio norteador dessa atitude está o desenvolvimento de uma consciência histórica da desigualdade trazida à tona pelo processo revolucionário que tem como palco a Europa e a América, e cujas expressões mais fortes são as revoluções Inglesa, Americana e Francesa. O fim desse processo corresponde ao início do vigor de um novo conceito de cidadania que tem como base o indivíduo e o status de igualdade.

A Revolução Inglesa ${ }^{3}$ (1640-1688), considerada a primeira revolução burguesa da história, tem como conseqüência a formação do primeiro país capitalista do mundo, a Inglaterra. Seu grande mérito é romper com os padrões de um Estado que governa apenas para uma aristocracia e colocá-lo em função da classe burguesa (ainda que esse novo semblante venha a ser reforçado apenas pela Revolução Francesa).

Dessa forma, a burguesia inglesa fortalece seus laços tanto com as outras classes sociais, como o proletariado, como também com outras nações, condição sine-qua-non para a afirmação capitalista. A cidadania é colocada definitivamente num novo patamar das relações sociais e, a partir daí, tem início um processo de valorização do trabalho e do trabalhador.

É nesse contexto que o filósofo inglês Thomas Hobbes (1588-1679) publica, em 1651, Leviatã. No livro, ele aponta o Estado como uma opção do indivíduo, devendo, portanto, servi-lo. Para Hobbes o poder do Estado

\footnotetext{
${ }^{2}$ O racionalismo é uma doutrina filosófica do século XVII que admite a razão como a única forma válida de conhecimento. Nesse sentido, funda as bases do conhecimento científico (COSTA, 1987: 30).

${ }^{3}$ A Revolução Inglesa, na verdade, compreende duas fases. Numa primeira ocorre a Revolução Puritana (1642-1660), quando o confronto entre forças monárquicas absolutistas e o Parlamento inglês provocam uma guerra civil no país, culminando com a decapitação do rei Charles I e a implantação da República Puritana. Mas a experiência dura menos de 20 anos. É a Revolução Gloriosa (1688) que derruba definitivamente o regime absolutista e dá início a uma monarquia constitucional.
} 
é absoluto, ao contrário do que pensa outro filósofo inglês, John Locke (1632-1704), arauto do liberalismo, e para quem esse poder é limitado. É no embate dessas formas de pensar o poder estatal sobre o indivíduo que se abre o espaço necessário para se discutir e legislar claramente, em documentos, os direitos humanos.

Surge a Carta de Direitos, o Bill of Rights, e a cidadania liberal, ainda que excludente (por ter como uma de suas prerrogativas a posse de bens materiais), dá um grande avanço ao apontar que "todos são iguais perante a lei". Para Marco Mondaine (PINSKY; BASSANEZI, 2003: 130) a Revolução Inglesa consegue inaugurar uma Era dos Direitos:

O contatrualismo liberal de Locke foi, sem dúvida, um dos maiores responsáveis pela edificação dessa nova era. Com ele, rompe-se com - "pacto de submissão" hobbesiano em nome de um "pacto de consentimento". No seu "estado de natureza", há uma situação de relativa paz, concórdia e harmonia, no qual os indivíduos dotados de racionalidade possuem um certo número de "direitos naturais": vida, liberdade e bens.

A Revolução Americana ${ }^{4}$ (1776) é bastante influenciada por pilares ideológicos e políticos dos pensadores europeus, especialmente Locke, e vai dar início à cidadania norte-americana. Seus princípios estão expressos tanto na Declaração de Independência como na Constituição dos Estados Unidos, esta com forte inspiração no Bill of Rights inglês. Para Leandro Karnal (PINSKY; BASSANEZI, 2003: 150), a característica central da cidadania norte-americana é a sua relação direta com a liberdade do indivíduo diante do Estado.

A Revolução Francesa ${ }^{5}$ (1789), assim como os dois outros processos anteriores, deslancha valores e formas de pensar que serão estendidas pelos séculos XIX e XX até os dias de hoje. Jean-Jacques

\footnotetext{
${ }^{4}$ A Revolução Americana resulta na independência dos Estados Unidos do domínio da Grã-Bretanha. O estopim da rebelião é a aprovação da Lei do Chá, que dava o monopólio do comércio do produto à Companhia Britânica das Índias Orientais, prejudicando os comerciantes norte-americanos. Em 1775, organizados militarmente, os colonos declaram guerra à metrópole. A Declaração da Independência, cuja redação tem a frente Thomas J efferson, é promulgada em 1776. Em 1783, por meio do Tratado de Versalhes, a Inglaterra reconhece a independência dos Estados Unidos.

${ }^{5}$ A Revolução Francesa tem como ponto de partida a revolta da burguesia, com o apoio popular, contra os privilégios da nobreza e do clero no reinado de Luís XVI. O ponto alto da revolução é a proclamação de uma Assembléia Nacional Constituinte e a Tomada da Bastilha, em 1789, por comerciantes, artesãos e assalariados parisienses.
} 
Rousseau (1712-1778) foi um dos grandes inspiradores dos ideais revolucionários na França. Para ele, a dominação, ou melhor, a representatividade, não se faz pela força, mas por uma opção vinculada a um pacto, a um "contrato social".

Rousseau ([s.d.]: 34) associa a cidadania a um pacto social fundamentado numa democracia direta. Para ele a cidadania é um instrumento de igualdade entre os homens:

(...) em lugar de destruir a igualdade social, o pacto fundamental substitui, ao contrário, uma igualdade moral e legítima naquilo que a natureza poderia trazer de desigualdade física entre os homens e que, podendo ser desiguais na força ou capacidade, tornam-se todos iguais por convenção e direito.

É nesse aspecto que a cidadania russoniana vai guardar uma relação íntima como a democracia moderna que, a rigor, pressupõe um governo que emana do povo e a ele permanece atrelado. Fora disso, não estaremos no âmbito de uma democracia legítima.

Para Nilo Odalia (PINSKY; BASSANEZI, 2003: 160-161), associados aos direitos do cidadão, surge no século XVIII a idéia de felicidade não mais como uma conquista individual, mas como uma meta a ser alcançada pela coletividade:

O homem só pôde pensar em felicidade como um projeto de sociedade, isto é, como uma possibilidade para todos os que nela vivem, quando criou os meios de fazer com que a educação, a produção de alimentos, a fabricação de coisas de que precisava tecidos, roupas, máquinas etc - aumentassem a tal nível que deixasse de ser um privilégio de poucos para ser uma possibilidade de todos. Isso não significou, nem significa hoje, que todos os homens tenham tudo o que queiram e que não exista ainda desigualdade e injustiça. Significa apenas que, a partir do século XVIII, com a chamada Revolução Industrial, o homem criou os instrumentos de que necessitava para produzir em abundância os bens de que dependia para viver mais confortavelmente.

E continua o autor: 
A idéia de felicidade assim concebida representou - como ainda representa - uma grande conquista humana, pois ainda hoje orienta todo o esforço do homem no sentido de uma sociedade mais justa e igualitária.

Na verdade, essa concepção de felicidade vai nortear não só a própria Revolução Francesa como também o pensamento socialista de alguns anos depois, como veremos adiante.

Em todo caso, o grande legado da Revolução Francesa é a conquista de direitos humanos e sua expressão numa Declaração dos Direitos do Homem e do Cidadão. O documento pretende-se universal e aponta os direitos civis dos homens, independente do país em que vivam e da etnia ou povo a que pertençam. Na Declaração permanecem os ideais de igualdade, fraternidade e liberdade repetidos como palavras de ordem do movimento e que constituem um marco e um instrumento de inspiração universal.

É importante destacar que os direitos humanos referendados com as revoluções dos séculos XVII e XVIII são universais e naturais, ao passo em que os direitos de cidadania são um conceito político, de expressão estatal. Maria Victoria de Mesquita Benevides Soares (1998: 41) observa:

(...) direitos de cidadania não são direitos universais, são direitos específicos dos membros de um determinado Estado, de uma determinada ordem jurídico-política. No entanto, em muitos casos, os direitos do cidadão coincidem com os direitos humanos, que são mais amplos e abrangentes.

Por outro lado, para a autora:

Os Direitos Humanos são universais e naturais, o que é considerado um direito humano no Brasil, também deverá sê-lo com o mesmo nível de exigência, de responsabilidade e de garantia em qualquer país do mundo, porque eles não se referem a um membro de uma sociedade política; a um membro de um Estado: eles se referem à pessoa humana em sua universalidade. Por isso são chamados direitos naturais, porque dizem respeito à dignidade da pessoa humana. São naturais também, por que existem antes de qualquer lei, e não precisam estar nela especificados para serem exigidos, reconhecidos, protegidos e promovidos. 
Para Soares (1998), a afirmação dos direitos humanos é a grande conquista deixada pela Idade Moderna, por seus pensadores e por suas revoluções. Esses princípios estiveram presentes e inspiraram a atual Declaração Universal dos Direitos Humanos (anexo 01), promulgada em 1948, e que até hoje serve de referência para a cidadania mundial ${ }^{6}$.

Mas é na Contemporaneidade, entre os séculos XVIII e XIX, com as teorias socialistas, que o pensamento social vai encontrar um novo paradigma para compreender não só a cidadania, mas também os direitos humanos e cidadãos no seio da organização política e econômica.

Os socialistas representaram definitivamente a incorporação da política na vida das classes trabalhadoras e proletárias. Criaram-se partidos e sindicatos e foram pregadas revoluções em nome de um modo de produção menos desigual entre patrões e trabalhadores. Um outro avanço importante foi a crescente abertura para a participação feminina no cenário das decisões políticas, tendo sido a pensadora Mary Wollstonecraft (1759-1797), autora de Reivindicação dos Direitos da Mulher, a desencadeadora das lutas por essas conquistas.

Foi o pensamento de Karl Marx (1818-1883) e Frederich Engels (1820-1895) que melhor expressou as idéias socialistas. Para os autores, somente com a superação do capitalismo seria possível o pleno exercício da cidadania e a sua extensão a todos. O Materialismo Histórico ou Marxismo denunciou a exploração do trabalhador capitalista e defendeu a construção de uma sociedade comunista.

Servindo para fundamentar essa conquista e forjar uma nova concepção de valores humanos, a cidadania marxista coloca claramente

\footnotetext{
${ }^{6}$ A este respeito, Comparato (2005) observa: “A Declaração abre-se com a proclamação dos três princípios axiológicos fundamentais em matéria de direitos humanos: a liberdade, a igualdade e a fraternidade". (...) "A formação histórica dessa tríade sagrada remonta a Revolução Francesa. Mas a sua consagração oficial em textos jurídicos só se fez tardiamente. A Declaração dos Direitos do Homem e do Cidadão de 1789, tal como o Bill of Rights de Virgínia de 1776, só se referem à liberdade e à igualdade. A fraternidade veio a ser mencionada, pela primeira vez - e, ainda assim, não como princípio jurídico, mas como virtude cívica -, na constituição francesa de 1791. Foi somente no texto constitucional da Segunda república francesa, em 1848 , que o tríptico veio a ser oficialmente declarado".
} 
em xeque a concepção da cidadania como um direito natural. Na sua acepção, ela é uma conquista social baseada não só em direitos, mas principalmente em deveres. Nas palavras de Marx (IANNI, 1992: 198):

Só quando o homem individual real readquire em si o cidadão abstrato e se converte, como homem individual, em ser genérico, em seu trabalho individual e em suas relações individuais; só quando o homem reconhece e organiza suas forces propres como forças sociais, e quando, portanto, já não separa de si a força social sob a forma de força política, só então se realiza a emancipação humana.

Alguns teóricos têm avançado na compreensão do conceito de cidadania nos séculos XX e XXI. Para Marshall (1967), a cidadania está dividida em três partes: os direitos civis, os direitos políticos e os direitos sociais. O autor observa que a conquista desses direitos, que pressupõem também deveres e obrigações, dá-se na Europa, de forma seqüencial e nessa ordem, a partir do século XVIII.

Os direitos civis, segundo Marshall (1967), são fundamentados na liberdade individual. Dizem respeito à posse do indivíduo sobre seu corpo; à sua possibilidade de locomoção, de ir e vir; de expressar publicamente suas idéias e de organizar-se. Eles pressupõem, ainda, formas organizadas de existência e relações sociais calcadas numa justiça independente, eficiente e acessível.

Os direitos políticos, uma conquista européia do século XIX, fundamentam-se no autogoverno e se referem à participação do indivíduo na vida, no gerenciamento do presente e do futuro político de sua nação. Eles são, em grande parte, legado da civilização grecoromana. Pressupõem o direito de votar e ser votado. A condição para a sua existência são os direitos civis. Não há como votar e ser votado conscientemente sem um indivíduo reconhecidamente livre e uma organização partidária bem estruturada e atuante.

Finalmente os direitos sociais, segundo Marshall, fundamentam-se na justiça social. Marcadamente conquistados na Europa do século XX, grande parte de sua vigência cabe ao Poder Executivo. Dizem respeito às 
necessidades do ser humano como comida, educação, trabalho e condições gerais de subsistência. Enfim, implicam na participação de todos na riqueza coletiva. Nesse ponto, o autor faz uma observação importante e aponta a educação popular como uma exceção na seqüência dos direitos. Apesar de ser um direito social, ela é um pré-requisito para a conquista dos outros direitos na medida em que permite que as pessoas possam conhecê-los, organizarem-se e lutarem por eles.

Para Marshall, portanto, cidadão é o homem livre que, por meio da educação, é capaz de organizar-se e administrar seu espaço dentro da sociedade, assegurando suas condições básicas de vida. O cidadão é agente e produto da democracia.

Boaventura de Souza Santos (2002: 45), partindo do pensamento de Norberto Bobbio, entende a democracia como um elemento relevante da cidadania e Ihe atribui um caráter claramente político.

Para ele, a democracia "se constitui de um conjunto de regras para a formação de maiorias, entre as quais valeria a pena destacar o peso igual dos votos e a ausência de distinções econômicas, sociais, religiosas e étnicas na constituição do eleitorado". No entanto, o autor observa que o aumento do controle da burocracia capitalista sobre o indivíduo no século XX foi um golpe sobre o cidadão e a democracia.

Com o acirramento das lutas de classes, especialmente a partir dos anos 80, os direitos humanos, a democracia e a cidadania foram reforçados como instrumentos em defesa dos direitos do trabalhador e passaram a merecer uma atenção especial como modeladora das tensões sociais. Numa releitura do Materialismo Histórico, Ellen M. Wood (2003: 184) reinterpreta a cidadania no alvorecer do século XXI. Para ela, na verdade, a concepção atual encobre as desigualdades cada vez mais acirradas na luta de classes.

Na democracia capitalista, a separação entre a condição cívica e a separação de classe opera nas duas direções: a posição sócio econômica não determina o direito à cidadania - e é isso o democrático na democracia capitalista -, mas, como o poder do 
capitalista de apropriar-se do trabalho excedente dos trabalhadores não depende de condição jurídica ou civil privilegiada, a igualdade civil não afeta diretamente nem modifica significativamente a desigualdade de classe - e é isso que limita a democracia no capitalismo. As relações de classe entre capital e trabalho podem sobreviver até mesmo à igualdade jurídica e ao sufrágio universal. Neste sentido, a igualdade política na democracia capitalista não somente coexiste com a desigualdade socioeconômica, mas a deixa fundamentalmente intacta.

Como produto desses paradoxos, em alguns momentos e em algumas sociedades, enfatiza-se o caráter civil, político ou social da cidadania. Assim, em diferentes momentos, ela pode significar a preponderância de um aspecto sobre outro. De acordo com Marshall, estaremos nestes casos diante de uma cidadania incompleta. Mas o autor também observa que a ausência de todos eles pode implicar numa nãocidadania.

Mas a cidadania de fato - entendida como cidadania plena - não implica na exclusão de nenhum dos seus três direitos e muito menos numa concessão de uns para outros. Pelo contrário, ela é práxis pura e permanente. Pinsky (PINSKY; BASSANEZI, 2003: 09) parte dos três direitos propostos por Marshall para conceituar a questão acrescentando preocupações bem peculiares à realidade atual:

\begin{abstract}
Ser cidadão é ter direito à vida, à liberdade, à propriedade, à igualdade perante a lei; é, em resumo, ter direitos civis. É também participar no destino da sociedade, votar, ser votado, ter direitos políticos. Os direitos civis e políticos não asseguram a democracia sem os direitos sociais, aqueles que garantem a participação do indivíduo na riqueza coletiva: o direito à educação, ao trabalho, ao salário justo, à saúde, a uma velhice tranqüila. Exercer cidadania plena é ter direitos civis, políticos e sociais.
\end{abstract}

A partir de um viés marxista, Pedro Demo (PENTEADO, 1985: 108), um dos autores que mais se preocupou com a formação cidadã como parte do processo educacional, entende o conceito exatamente na perspectiva da dinâmica histórica. A cidadania é definida por ele como

(um) processo histórico de conquista popular, através do qual a sociedade adquire, progressivamente, condições de tornar-se sujeito 
histórico consciente e organizado, com capacidade de organizar e conceber projeto próprio. O contrário significa a condição de massa de manobra, de periferia, de marginalização.

Uma visão otimista, sem desprezar o embate construtivo da cidadania, é apontada por Maria de Lourdes M. Covre (2003: 10):

Só existe cidadania se houver a prática da reivindicação, da apropriação de espaços, da punga para fazer valer os direitos do cidadão. Neste sentido, a prática da cidadania pode ser a estratégia, por excelência, para a construção de uma sociedade melhor.

Os estudos de Hannah Arendt têm especial importância para pensar a cidadania contemporânea. O conceito fundamental de Arendt (1987:

15) para compreender a cidadania é a ação. Segundo ela, na vita activa o ser humano executa três atividades fundamentais: o labor, relacionado com as atividades vitais da vida biológica do indivíduo, como comer; o trabalho, associado à condição da intervenção humana sobre a natureza, dando à vida humana um grau de artificialidade e mundanidade e, finalmente, a ação, "correspondente à condição humana da pluralidade, ao fato de que homens, e não o Homem, vivem na terra e habitam o mundo".

A ação de Arendt, portanto, aponta o indivíduo como um ser necessariamente social, dialógico e político (1987: 16):

A ação seria um luxo desnecessário, uma caprichosa interferência com as leis gerais do comportamento, se os homens não passassem de repetições interminavelmente reproduzíveis do mesmo modelo, todas dotadas da mesma natureza e essência, tão previsíveis quanto a natureza e a essência de qualquer outra coisa. A pluralidade é a essência de qualquer condição humana pelo fato de sermos todos os mesmos, isto é, sem que ninguém seja exatamente igual a qualquer pessoa que tenha existido, exista ou venha a existir.

Caminhado por uma linha que vai desde sua concepção como ato político (Aristóteles) até a construção de uma sociedade sem classes (Marx), Arendt aponta a cidadania como uma construção coletiva e um direito, produto de um dever. João Cardoso Palma Filho (1998: 108) explicita bem o pensamento da autora: 
Para Aristóteles, cidadania implicava a possibilidade concreta do exercício da atividade política, ou seja, ser cidadão significava poder governar e ser governado. Arendt enriquece o enfoque aristotélico, ao conceber a cidadania como 'o direito a ter direitos, considerado como primeiro direito humano fundamental, do qual todos os demais derivam-se'. Em outros termos, a cidadania inscreve-se no quadro geral dos direitos fundamentais do ser humano. Embora direito fundamental, a cidadania precisa ser conquistada; não é dada, resulta de um agir conjunto, é uma construção coletiva, opondo-se, portanto, à concessão, ao privilégio. Não sendo concessão, não pode ser revogada ou retirada. O conceito de cidadania em Arendt possui uma abrangência universal, nada tendo a ver com território ou nacionalidade. É uma qualidade do ser humano, mas que com ele não nasce - precisa ser conquistada. Ou seja, ninguém nasce cidadão; torna-se cidadão. A cidadania não é uma qualidade natural nem apenas do indivíduo, ao contrário, é social.

A História nos mostra que a cidadania não se realiza apenas por meio de direitos. Ao contrário, há também deveres a serem cumpridos para conquistá-la. Fugir a essa responsabilidade é renunciar à própria cidadania.

Cidadania é identidade individual no contexto social; é a luta incessante do indivíduo pelo seu direito à vida, à liberdade, à dignidade e, sobretudo, à compreensão do seu direito a ela a partir do compromisso com os deveres que ela própria pressupõe. Em outras palavras, cidadania é identidade social. É mais que a consciência de estar no mundo: é ter também a consciência de participar dele e, por isso, ter compromissos e responsabilidades com ele. Nesse sentido, a cidadania firma-se como um conceito irremediavelmente ligado aos direitos humanos e à democracia. 


\subsection{Da Cidadania Brasileira}

Assim como no exterior, no Brasil a cidadania tem sido componente de estudo de sociólogos, historiadores e educadores. Mas o que tem sido e o que é ser cidadão no Brasil? Até que ponto o brasileiro conhece seus direitos de cidadão e até que ponto conhece seus deveres?

Uma condição historicamente palpável para o desenvolvimento da cidadania é a idéia Estado-nação. As lutas e conquistas decorrentes das revoluções Inglesa, Americana e Francesa reforçam essa idéia. Portanto, para José Murilo de Carvalho (2003), só podemos começar a falar em cidadania brasileira a partir de 1822 quando, a partir da Independência, começa a firmar-se um sentimento de nação.

No entanto, para Carvalho (2003, 17-18), naquele momento esse sentimento ainda era ínfimo, já que a Independência do Brasil resultou muito pouco de um conflito popular e significou bem mais um acordo envolvendo a elite nacional, a Coroa Portuguesa e a Inglaterra:

Ao proclamar a independência de Portugal em 1822, o Brasil herdou uma tradição cívica pouco encorajadora. Em três séculos de colonização (1500-1822), os portugueses tinham construído um enorme país dotado de unidade territorial, lingüística, cultural e religiosa. Mas tinham também deixado uma população analfabeta, uma sociedade escravocrata, uma economia monocultora e latifundiária, um Estado absolutista. À época da independência, não havia cidadãos brasileiros, nem pátria brasileira.

E continua (2003, 23-24):

Não havia república no Brasil, isto é, não havia sociedade política; não havia "repúblicos", isto é, não havia cidadãos. Os direitos civis beneficiavam a poucos, os direitos políticos a pouquíssimos, dos direitos sociais ainda não se falava. Pois a assistência social estava a cargo da I greja e de particulares.

Ainda assim, pelo seu caráter de luta pela democracia e pelos direitos humanos, merecem ser consideradas durante o Brasil Colônia 
(1500-1822) algumas manifestações cívicas, como as revoltas escravas, como a de Palmares. Embora severamente esmagadas pelo governo, pelas elites e pelos militares, elas serviram para marcar focos de insatisfação popular durante a fase colonial.

Além dessas, revoltas políticas como a Inconfidência Mineira (1789), inspirada nos ideais iluministas do século XVIII, a Revolta dos Alfaiates (1798), na Bahia, influenciada pela Revolução Francesa, e a Revolução Pernambucana de 1817, de inspiração iluminista, apontaram insatisfações políticas e um sentimento de povo e de nação. No entanto, ainda que alguns tenham sido mais populares do que outros ${ }^{7}$, esses conflitos constituíram insurreições da elite contra o controle colonial, não chegando a representar uma luta popular. Além disso, nem sempre traziam reivindicações baseadas em um sentimento efetivamente nacional ${ }^{8}$.

Para Carvalho (2003: 83), de 1822 a 1930, o Brasil experimentou uma primeira fase de cidadania, que ele considera uma cidadania em negativo, ou seja, uma cidadania que não foi produto da consciência nem da participação popular e nem era estendida democraticamente a todos os cidadãos:

(...) até 1930 não havia povo organizado politicamente nem sentimento nacional consolidado. A participação na política nacional, inclusive nos grandes acontecimentos, era limitada a pequenos grupos. A maioria do povo tinha com o governo uma relação de distância, de suspeita, quando não de aberto antagonismo. Quando o povo agia politicamente, em geral o fazia como reação ao que considerava arbítrio das autoridades. Era uma cidadania em negativo, se se pode dizer assim. O povo não tinha lugar no sistema político, seja no Império, seja na República. O Brasil ainda era para ele uma realidade abstrata. Aos grandes acontecimentos políticos nacionais, ele assistia, não como bestializado, mas como curioso, desconfiado, temeroso, talvez um tanto divertido.

\footnotetext{
${ }^{7}$ A Revolta dos Alfaiates foi a mais popular, contando com a participação de militares de baixa patente, artesãos e escravos.

${ }^{8}$ A Revolta Pernambucana correspondia mais a um sentimento de parte da elite pernambucana do que, de fato, brasileira. Ela desembocou na Confederação do Equador, uma tentativa de algumas províncias do Nordeste brasileiro - Pernambuco, Ceará, Paraíba, Rio Grande do Norte - de criar um país independente em 1824, logo em seguida ao surgimento do Império, em 1822.
} 
Carvalho entende que o primeiro entrave para uma efetiva cidadania brasileira foi de caráter político e as dificuldades para o exercício do voto foram sua característica mais marcante. Até 1930 as mulheres não tinham direito expressarem-se nas urnas e os homens votantes - o que incluía inicialmente todos os maiores de 25 anos ou 21 , se casados ou economicamente independentes, mas depois apenas os alfabetizados - decidiam o destino do País. Além disso, até o início do século XX o processo eleitoral transcorria em clima de aberta corrupção política, o que incluía compra de votos, ameaças a eleitores e desrespeito ao próprio processo eleitoral.

Para o autor, alguns aspectos dificultaram também a cidadania civil no Brasil até os primeiros anos da República. O primeiro deles diz respeito à maneira como vivia o negro, inicialmente escravizado e, depois da Lei Áurea, submetido a difíceis condições de existência, trabalho e salário. As grandes propriedades e um conseqüente coronelismo era outro grande obstáculo à cidadania.

Até o final do século XIX não se pode esperar muito em relação à cidadania social de um país que pouco havia construído nos aspectos político e civil. Só nas primeiras décadas do século XX apareceram avanços nos direitos sociais dos brasileiros. No novo cenário, a presença do imigrante europeu trouxe uma nova mentalidade sobre os direitos do trabalhador. A maneira como eram tratados no Brasil era acompanhada em seus países e seus direitos foram por isso, em alguma medida, reivindicados e preservados.

Além disso, ideais anarquistas e socialistas, de forte conotação política, encontram terreno para proliferar, especialmente no Sul e Sudeste brasileiros. Seus defensores ajudaram na construção da cidadania nacional, ainda que em alguns casos tenham sido penalizados em suas conquistas civis e políticas. Tânia Regina de Luca (PINSKY; BASSANEZI, 2003: 473) descreve o quadro: 
O período de 1917-1921 registrou, nas cidades do Rio de Janeiro e São Paulo, as maiores mobilizações e greves da Primeira República, encaradas com simpatia por vários setores sociais, que reconheciam as reivindicações como justas e razoáveis. A escassez de produtos provocada pela Primeira Guerra Mundial acarretou aumento significativo no custo de vida, o que penalizava não apenas os operários, mas a população urbana como um todo. A agitação, aliada ao contexto do pós-guerra, marcado pela presença de um Estado proletário na União Soviética, manifestações operárias em vários países da Europa e reconhecimento, em acordos internacionais, da existência da questão social e da necessidade de enfrentá-la, colaboraram para que finalmente se admitisse a interferência do Estado nas relações entre o capital e o trabalho, aspecto consagrado na reforma constitucional de 1926. É bom frisar, porém, que a disposição de legislar sobre o tema foi concomitante à perseguição sistemática ao movimento organizado, facilitada pelo estado de sítio (1922-27) e pela aprovação, em 1921, da lei de repressão ao anarquismo.

Só a partir de meados dos anos 30 é que se pode falar, de fato, numa cidadania brasileira. Para Carvalho (2003), uma das razões para isso é o desenvolvimento de uma identidade nacional ${ }^{9}$. Para o autor, a Primeira Guerra Mundial, que serviu para despertar preocupações com a defesa do País entre civis e militares; a Semana de Arte Moderna 22, buscando discutir e referendar uma cultura brasileira; e as crises econômicas como a do café, em São Paulo, favorecendo a eclosão de greves operárias, contribuíram decisivamente nesse sentido.

Ainda que de forma precária, houve participação popular na chamada Revolução de 30 e nas agitações e nos movimentos políticos que se seguiram. O povo passou de observador dos processos e das lutas sociais para ocupar espaço, ainda que inicialmente tenha sido como coadjuvante.

Entre 1937 e 1945, um grande ganho da cidadania brasileira ocorreu no âmbito dos direitos sociais, especialmente do trabalhador. Situação ambígua, aliás, se levarmos em conta que no mesmo período os direitos civis e políticos foram drasticamente cerceados por um

\footnotetext{
${ }^{9}$ Apesar de algumas experiências anteriores, como a Guerra do Paraguai, que procurou estimular um sentimento nacional no povo brasileiro, levantes dos séculos XVIII e XIX, como a Revolução Farroupilha (no Ro Grande do Sul) e a Insurreição Pernambucana (em Pernambuco) trabalhavam bem mais com um caráter divisionista do que integracionista do ponto de vista nacional.
} 
Estado ditatorial. Em todo caso, a conquista dos direitos sociais inaugura a cidadania brasileira.

Para Covre (2003: 55), o período que vai de 1945 a 1964 representa um dos momentos mais democráticos da vida brasileira ainda que de uma chamada "democracia populista" - e significa um grande passo na conquista de direitos políticos. A autora caracteriza os resultados obtidos nesse período:

\begin{abstract}
O Estado atendeu em parte às reivindicações populares, procurando desmobilizar a organização operária. Lembre-se aqui o efeito das leis trabalhistas 'doadas', da 'liberação' do sindicato. Ou seja, o sindicato tem permissão de existir, mas é atrelado ao Estado pelos chamados pelegos, que fazem para os trabalhadores a política trabalhista entre o sindicato e o Estado.

Mas a ambigüidade dessa proposta democrática levou à existência de certos direitos políticos: voto sistemático para todos os cargos (prefeito, governador, vereador, deputado, senador e presidente), processo de greve mais ou menos assegurado. Pressões políticas das organizações populares e, basicamente, o mínimo respeito dos governantes pela Constituição de 1946 fizeram com que fossem um tanto atendidos direitos sociais - educação, habitação, saúde, segurança no trabalho, aposentadoria etc.
\end{abstract}

O período seguinte, os anos do governo militar, é um quadro particularmente rico para a análise da cidadania brasileira. De 1964 a 1985 os militares assumiram o poder no País e a repressão e o cerceamento aos direitos civis e políticos comprometeram a frágil cidadania nacional.

Foram assinados atos institucionais, como o Al-5, que fecharam o Congresso Nacional e acabaram com a garantia do habeas-corpus. Além disso, ocorreram mortes truculentas em protestos populares, como a do estudante Edson Luís, em março de 1968, no Rio de Janeiro.

Nesse período, a Associação Brasileira de Imprensa ( $A B I$ ), assim como entidades como a Ordem dos Advogados do Brasil (OAB) e a Sociedade Brasileira para o Progresso da Ciência (SBPC), além de artistas e intelectuais, tiveram um papel fundamental na luta em favor da democracia, dos direitos humanos e da cidadania. 
Uma ambigüidade do período, assim como aconteceu com a ditadura varguista, foi a evolução dos direitos sociais. A criação do INPS (Instituto Nacional da Previdência Social) e do FGTS (Fundo de Garantia por Tempo de Serviço) são mostras disso. Mais uma vez essas garantias funcionam muito menos como uma resposta concreta a pressões populares e mais como uma prática assistencialista e populista.

A conquista de direitos civis, por fim, passa a ser uma prerrogativa dos anos 80 com o processo de democratização do País, notadamente a partir de 1985, quando assume o primeiro presidente civil desde 1964.

As liberdades de expressão, de organização sindical e de imprensa são grandes trunfos das novas conquistas. No entanto, talvez o principal deles tenha sido o afloramento de um sentimento nacional até então sem precedentes e, em conseqüência disso, o estabelecimento de uma nova mentalidade e de um novo conceito para a cidadania brasileira até então torpe e pouco participativa.

Rubens Naves (PINSKY; BASSANEZI, 2003: 569) ilustra bem esse quadro contemplando a cidadania a partir dos movimentos sociais e do terceiro setor:

A partir de meados da década de 1980 , os movimentos sociais incluíram parcelas mais amplas da sociedade. Surgiram os movimentos ecológicos, que transcendiam a divisão política entre direita e esquerda e, também, o movimento em defesa dos direitos do consumidor. Ambos resultariam na criação de novas leis, como o Código do Consumidor, e no fortalecimento do Ministério Público como instrumento da sociedade civil para fazer valer suas reivindicações.

De fato, esses avanços estão referendados na Constituição da República Federativa do Brasil de 1988, conhecida como a Constituição Cidadã ${ }^{10}$, que apregoa, em seu artigo primeiro: “A República Federativa do Brasil (...) constitui-se como Estado Democrático e de Direito e tem

\footnotetext{
${ }^{10}$ A Constituição, promulgada em 5 de outubro de 1988, foi chamada “Cidadã" pelo então deputado Ulysses Guimarães, na época presidente da Assembléia Nacional Constituinte, por entender que sua ênfase estava na defesa do cidadão, e não do Estado.
} 
como fundamentos: I - a soberania; II - a cidadania; III - a dignidade da pessoa humana; IV - os valores sociais do trabalhador e da livre iniciativa e V - o pluralismo político".

No entanto, apesar dos avanços da democracia e dos direitos humanos, especialmente das conquistas civis, para Carvalho (2003: 07) a cidadania brasileira ainda tem muito a conquistar:

Havia ingenuidade no entusiasmo. Havia a crença de que a democratização das instituições traria rapidamente a felicidade nacional. Pensava-se que o fato de termos reconquistado o direito de elegermos nossos prefeitos, governadores e presidente da República seria garantia de liberdade, de participação, de segurança de desenvolvimento, de emprego, de justiça social. De liberdade, ele foi. A manifestação do pensamento é livre, a ação política e sindical é livre. De participação também. $O$ direito do voto nunca foi tão difundido. Mas as coisas não caminharam tão bem em outras áreas. Pelo contrário. Já 15 anos passados desde o fim da ditadura, problemas centrais da nossa sociedade, como a violência urbana, o desemprego, o analfabetismo, a má qualidade da educação, a oferta inadequada de serviços de saúde e saneamento, e as grandes desigualdades sociais ou econômicas ou continuam sem solução, ou se agravam, ou, quando melhoram, é em ritmo muito lento. Em conseqüência, os próprios mecanismos e agentes do sistema democrático, como as eleições, os partidos, o Congresso, os políticos, se desgastam e perdem a confiança dos cidadãos.

Tomando como base o trabalho de Marshall (1967), Carvalho (2003) chama atenção para o fato da cidadania brasileira constituir-se numa pirâmide invertida em relação à cronologia apontada pelo autor na esfera européia. Mais que uma cronologia, os estudos de Marshall apontam um caminho natural, já que os direitos civis são o fundamento para a conquista de direitos políticos. Estes, por sua vez, são a base para a construção dos direitos sociais.

Em outras palavras, como também reforça a concepção de cidadania de Arendt (1987), é a partir do momento em que o indivíduo toma consciência da sua existência e do seu compromisso com o espaço social que ocupa e vê respeitado e assegurado o seu papel que ele está apto para o exercício democrático do voto. E é a partir do voto, da eleição de uma representatividade, que ele vai poder esperar que o seu 
legítimo representante (o governo e as demais instituições representativas) venha assegurar-Ihe a dignidade das condições de vida e trabalho.

No Brasil, a partir da ditadura varguista, primeiro foram assegurados os direitos sociais. Em seguida, a partir de 1945, tiveram espaço os direitos políticos (factualmente confirmados a partir de 1985) e finalmente, a partir da redemocratização e da Constituição de 1888, a conquista dos direitos civis.

Carvalho entende que esse processo produziu algumas peculiaridades à concepção de cidadania no Brasil, resultado de num envolvimento limitado da sociedade com a construção de uma nação democrática e comprometida com os direitos humanos. Por isso, para ele, não há como falar hoje de uma cidadania brasileira plena.

Os conflitos entre ricos e pobres, produto de uma das mais desiguais distribuições de renda do planeta, talvez sejam a parte mais visível dessas inversões.

Se por um lado os serviços públicos de assistência social não conseguem atender aos anseios e às demandas populares, por outro, a questão da segurança individual tem sido um grave problema para as classes de maior poder aquisitivo.

Num texto sobre a questão das desigualdades sociais brasileiras, o escritor e jornalista Jurandir Freire (VERÍSSIMO, 2000: 88) aponta que as elites nacionais sofrem de um completo alheamento em relação ao outro e de uma irônica irresponsabilidade em relação a si mesma. Para o autor se, por um lado há uma violência que sobressalta a vida dos ricos, por outro, há também uma violência que estes cometem contra os pobres ao lidar com a miséria e a indigência como naturais. Nesse ponto, o autor observa que está na hora dessa própria elite assumir suas responsabilidades. Se não pelo outro, pelo menos por si mesma: 
Sem uma discussão dos valores ou do quadro institucional que nos constitui enquanto sujeitos sociais, inclusive e especialmente em nossa vida privada, dificilmente conseguiremos retirar as elites da inércia auto e heterodestrutiva. Sem um esforço para concebermos novas formas de relações familiares, novas modalidades de relações sexuais, afetivas e amorosas; novos estilos de convivência e sociabilidade; novas atitudes diante do progresso científico e tecnológico; novas atitudes diante da transmissão do saber e da tradição democrático-humanista que é nossa, dificilmente poderemos produzir o encantamento necessário à paixão transformadora capaz de restituir à figura do próximo sua dignidade moral. O caminho é longo e penoso. Mas navegar é preciso, e sem uma bússola na mão e um sonho na cabeça nada teremos, salvo a rotina do sexo, droga e credit card. 


\title{
CAPÍTULO I I
}

\section{Do J ornalismo como instrumento da Cidadania}

\author{
Todo o homem tem direito à liberdade de opinião e \\ expressão; este direito inclui a liberdade de, \\ sem interferências, ter opiniões e de procurar, \\ receber e transmitir informações \\ e idéias por quaisquer meios, \\ independentemente de fronteiras.
}

Artigo XIX

da Declaração Universal dos Direitos Humanos

Bill Kovach e Tom Rosenstiel (2004) localizam o surgimento do jornalismo no início do século XVII, na Europa. Especialmente na Inglaterra, os indivíduos reuniam-se em espaços públicos, como cafés, para comentar as novidades. Algum tempo depois, na Inglaterra e nos Estados Unidos, as novidades e os comentários começaram a ser reunidos, redigidos e publicados para leitores ávidos por novidades e notícias.

Assim, a notícia aparece na história como uma necessidade ligada ao que Mitchell Stephens chama de instinto de percepção. Segundo Stephens (Kovach; Rosenstiel, 2004: 35) os homens buscam as notícias porque precisam saber o que acontece do outro lado do país e do mundo e estar a par de fatos que vão além da sua própria experiência. O conhecimento desses fatos, por meio do jornalismo, traz segurança para planejar e administrar sua a própria vida.

Para alguns autores o jornalismo tem servido como um dos alicerces para a consolidação dos direitos humanos, da democracia e da cidadania. A esse respeito Kovach e Rosenstiel (2004: 31-32), para 
quem a finalidade mais precípua do jornalismo é com a liberdade e com o autogoverno do cidadão, ao entrevistarem profissionais de jornalismo de diversos continentes, concluíram:

\begin{abstract}
À medida que ouvíamos cidadãos e jornalistas, ouvíamos que essa obrigação para com a cidadania engloba vários elementos. A imprensa ajuda a definir nossas comunidades, nos ajuda a criar uma linguagem e conhecimentos comuns com base na realidade. (...)

A imprensa funciona como um guardião, tira as pessoas da letargia e oferece uma voz aos esquecidos.

(...)

É difícil, olhando retrospectivamente, até mesmo separar o conceito de jornalismo do conceito de criação de uma comunidade e mais tarde da democracia. O jornalismo é tão fundamental para essa finalidade que (...) as sociedades que querem suprimir a liberdade devem primeiro suprimir a imprensa.
\end{abstract}

A cidadania, já afirmamos, não implica na exclusão de nenhum dos direitos apontados por Marshall (1967) - o civil, o político e o social - e também não é uma concessão de uns para outros. Pelo contrário: ela é práxis permanente. Retomando o conceito a que chegamos no capítulo anterior:

\begin{abstract}
Cidadania é a luta incessante do indivíduo pelo seu direito à vida, à liberdade e à dignidade e, sobretudo, à compreensão do seu direito a ela a partir do compromisso com os deveres que ela própria pressupõe. Em outras palavras, cidadania é identidade social. É mais que a consciência de estar no mundo: é ter também a consciência de participar dele e, por isso, ter compromissos e responsabilidades com ele.
\end{abstract}

E qual tem sido o compromisso e a função da imprensa e do jornalismo nas conquistas e na defesa da cidadania? A partir de Kovach e Rosenstiel (2004), podemos entender o jornalismo como uma prática profissional alicerçada na cidadania, empenhada em apurar, veicular e, em alguns casos, aprofundar a informação de atualidade, regida por um conjunto de valores éticos historicamente construídos.

A Pragmática do Jornalismo, ao trabalhar com a intencionalidade do ato comunicativo, constitui um caminho para uma compreensão da 
atuação do jornalista comprometida com a cidadania e com conteúdos relacionados aos direitos humanos e à democracia, ligada à ética e à responsabilidade social da profissão. Como diz Manuel Carlos Chaparro (1994: 13): “Na essência desta proposta está a convicção de que a intenção é a liga que funde Ética, Técnica e Estética, tríade solidária e inseparável das ações jornalísticas".

Chaparro estabelece que é através da Ética fundida à Técnica que o jornalismo chega à Estética do relato verdadeiro. Com base no artigo XIX da Declaração Universal de Direitos Humanos que apresentamos na abertura deste capítulo o autor observa (1994: 82):

Sempre que um editor ou um repórter - por incompetência, arrogância, interesse pessoal, ambição de poder, irresponsabilidade profissional, subalternidade a quem o controla ou qualquer outro motivo - priva o leitor da notícia correta e plena, trai o principal e mais belos dos compromissos que tem com a construção e o aperfeiçoamento de uma sociedade livre: assegurar a 'todo indivíduo' o direito de ser informado. Com relato veraz.

João Somma Neto (2002), seguindo a linha de pensamento de Chaparro, pondera sobre as intenções e os compromissos da imprensa:

Temos diante de nós uma prática jornalística voltada à busca e difusão de informações realmente importantes para a vida social, mas antes de tudo, o jornalismo praticado representa interesses, fala e influencia em nome desses interesses sutilmente presentes nos produtos elaborados e transmitidos a um público ávido, consumidor de notícias, as quais em essência atuam na construção parcial de uma realidade mostrada como verdade imediata.

Nesse mesmo caminho, a pesquisadora Adélia Barroso Fernandes (2002) observa:

O jornalismo, mesmo sem aprofundar-se, obviamente, nas discussões filosóficas, políticas e históricas que envolvem as questões dos direitos humanos, mesmo sendo, muitas vezes, superficial e retrógrado numa ou noutra abordagem, traz à cena pública novos atores sociais, e uma maneira de olhar e reconhecer conflitos que os envolvem, e as tentativas de mudar os padrões vigentes em que se acham. O jornalismo torna-se, assim, um espaço público fundamental para a democracia e para os direitos humanos. 
O jornalista deve ser, assim, um sujeito consciente que, a partir da valorização constante do seu próprio trabalho, construa condições para o florescimento da crítica social a partir de seu púbico. Por outro lado, não é função do jornalismo levantar bandeiras ou defender causas corporativistas, mas respeitar o direito de 'todo indivíduo' de ser informado, 'com relato veraz'.

O jornalismo tem, portanto, um referencial pragmático de intencionalidade. Esse referencial pode ser desenvolvido não apenas no conjunto dos valores da sociedade, mas também pode e deve ser instrumentalizado na formação profissional do jornalista, seja no currículo, nas práticas laboratoriais ou na relação estabelecida na escola entre docentes e discentes.

A função da imprensa é agendar as discussões de relevância social e de interesse público. Cabe a ela informar, mediar, transmitir a informação para que os acontecimentos sejam captados pelo público da notícia, o homem comum. Uma imprensa ética e socialmente responsável é aquela que age em nome do bem comum, respeitando e resguardando os direitos humanos e a democracia. Filiando-se intencionalmente, portanto, à cidadania.

Além de uma intenção, o jornalismo é também produto de uma construção; de uma ação. Retomando o conceito de ação de Arendt (1987) e transportando-o para o contexto jornalístico, entendemos que as notícias - como produto de uma construção por parte do jornalista, da empresa jornalística e / ou da ordem burocrática que rege a profissão - terminam sendo o resultado de uma intenção e de uma ação. Estas, fazendo com que determinados temas sejam ou não conhecidos, discutidos. Agendados, portanto.

Assim, a teoria do agendamento ou agenda-setting, desde que levando em consideração a cidadania e sua relação com os direitos humanos, a democracia, a ética e a responsabilidade social da 
imprensa, representa um caminho coerente para apreendermos um modelo de jornalismo para este estudo.

A origem do conceito de agendamento está nas discussões sobre a opinião pública. Na primeira metade do século $X X$, uma contribuição importante para os estudos nessa área veio do norte-americano Robert E. Park, ao trabalhar a notícia como forma de conhecimento.

Tomando como base os conceitos de 'conhecimento de' (intuitivo) e 'conhecimento acerca de' (científico), Park conclui que este último, pela sua sistematização, é articulável e, portanto, é comunicação. O autor, a partir dessa análise, situa aí a notícia, definida pelo interesse público, diferente de formas de comunicação persuasivas, que são assimiladas de forma intuitiva. Para ele, é a partir da notícia que surge a opinião pública (apud STEINBERG, 1966: 176):

\begin{abstract}
A primeira reação típica do indivíduo a uma notícia será, provavelmente, o desejo de repeti-la a alguém. Isso gera a conversação, desperta novos comentários e talvez uma discussão. Mas o que há nesse fato de singular é que, iniciada a discussão, o acontecimento discutido deixa de ser notícia e, sendo diferentes as interpretações de um acontecimento, as discussões se transferem do plano da notícia para o dos problemas que ela suscita. 0 choque de opiniões e pareceres, que a discussão invariavelmente evoca, termina, via de regra, numa espécie qualquer de consenso ou opinião coletiva - que nós denominamos opinião pública. É na interpretação dos acontecimentos presentes, ou seja, da notícia, que se funda a opinião pública.
\end{abstract}

Essa relação entre notícia e opinião pública, no entanto, já havia sido estudada há alguns anos pelo também norte-americano Walter Lippmann. Jornalista de grande atuação em pesquisas de opinião nos Estados Unidos da primeira metade do século passado, Lippmann elaborou uma das mais respeitadas obras sobre cultura de massa e opinião pública da época, com ressonância até hoje.

A sua contribuição está na desmistificação da crença de que a mídia e, por extensão, o jornalismo, trabalham com a representação fiel dos acontecimentos e do mundo. Para o autor, ao invés de reproduzilos, a mídia e a imprensa terminam por determinar uma outra realidade. 
A notícia seria definida, para ele, pela relevância do acontecimento no contexto social. Para Lippmann "a notícia não é um espelho das condições sociais, mas o relato de um aspecto que se impôs". É seguindo essa linha de pensamento que o autor aproxima também os conceitos de notícia e opinião pública (apud STEINBERG, 1966: 197):

A notícia que não oferece ao leitor a oportunidade de entrar na luta que ela descreve não pode interessar a um grande público. É preciso que o público participe da notícia, como participa do drama, pela identificação pessoal... Assim como toda a gente sustém a respiração quando a heroína está em perigo (...), assim, de maneira mais sutil, entra o leitor na notícia.

Por causa desses estudos, Lippmann é considerado um dos primeiros formuladores (senão, o primeiro) do que hoje conhecemos como agenda-setting. No entanto, a formulação efetiva do conceito surge nos Estados Unidos em finais da década de 60 com Maxwell E. McCombs e Donald L. Shaw. O conceito vai inspirar numerosas pesquisas a partir dos anos 70. Shaw observa (apud WOLF, 1994: 130):

(...) em conseqüência da ação dos jornais, da televisão e dos outros meios de informação, o público sabe ou ignora, presta atenção ou descura, realça ou negligencia elementos específicos dos cenários públicos. As pessoas têm tendência para incluir ou excluir dos seus próprios conhecimentos aquilo que os mass media incluem ou excluem do seu próprio conteúdo. Além disso, o público tende a atribuir àquilo que esse conteúdo inclui uma importância que reflete de perto a ênfase atribuída pelos mass media aos acontecimentos, aos problemas, às pessoas.

O amadurecimento dos estudos leva os a autores a observar que (apud TRAQUINA, 2003: 33-34):

Novas investigações, explorando as conseqüências do agendamento do enquadramento dos mídia, sugerem que os mídia não só nos dizem EM QUE PENSAR, mas também COMO PENSAR NISSO e, conseqüentemente, O QUE PENSAR.

Agendar e trazer um tema para discussão pública, portanto, não corresponde apenas a uma transmissão de fatos que compõem nossa 
realidade, como ponderava a teoria do espelho ${ }^{11}$. Para Traquina (2003), o agendamento é uma construção sujeita não só a erros e deslizes acidentais, mas também a intenções e a formas de manipulação. Analisando o caso brasileiro, Chaparro (1994: 108) observa:

O escamoteio ou a distorção de informações; as pautas motivadas por interesses particulares não revelados; a irresponsabilidade com que se difundem novas informações ao público; a acomodação dos repórteres a um jornalismo de relatos superficiais; os textos confusos e imprecisos; a facilidade com que a imprensa acolhe, sem apurar, denúncias que favorecem ou prejudicam alguém; a freqüente prevalência do marketing sobre as razões jornalísticas; o desprezo pelo direito de resposta; a arrogância com que se protege o erro e se faz a apropriação social do direito à informação (direito do leitor) - são claros sintomas de um desequilíbrio de identidade do jornalismo, enquanto função social.

O final do século $X X$ e o início do século $X X I$ documentam um dos períodos de maior fluxo de comunicação em todo o mundo. Mas esse desenvolvimento quantitativo não parece vir acompanhado de uma evolução qualitativa nas relações humanas e sociais.

Alguns teóricos postulam que a maior disponibilidade midiática, ao invés de implicar num maior conhecimento e entendimento dos fatos, pode significar um aumento no grau de desinformação. Segundo Leão Serva (1999: 131-132):

Entre os instrumentos de construção da notícia se alinham procedimentos, voluntários ou não, que produzem essa percepção alterada. Procedimentos de edição, de submissão, de redução, de saturação e de informação que tornam a representação um signo com pouca fidelidade ao original.

\section{E continua Serva:}

Parte desses procedimentos que provocam distorção são essenciais ao sistema econômico da informação tal como ele se organiza hoje em meios de comunicação. A necessidade de sua manutenção impõe uma constante criação de demanda por informação.

\footnotetext{
${ }^{11}$ A teoria do espelho, surgida em meados do século XIX para explicar as notícias, pressupunha que elas são como são porque a realidade assim as determinava. Assim, desconsiderava a notícia e o jornalismo como uma construção A PARTIR da realidade, como fazem as teorias que a sucedem. Como exemplo podem ser citadas a teoria do gatekeeper, segundo a qual as notícias são produto das intenções do jornalista, e a teoria estruturalista, que considera que as notícias são produto dos interesses da ordem social e de definidores primários.
} 
Assim, o jornalismo concede informação, surpreende o leitor, provoca e aplaca sua curiosidade, para em seguida retirar o fato da ordem do dia, relaxar a curiosidade, provocar esquecimento, atenuar a atenção ao fato narrado.

Mas se o jornalismo e a notícia podem, por um lado, ser aliados incondicionais da ordem dominante e dos valores do mercado, por outro, podem funcionar como importantes inspiradores dos debates cidadãos, como analisam Kovach e Rosenstiel (2004). Esta é também a concepção defendida por Traquina (2003: 171) ao designar o jornalismo cívico como um modelo de imprensa cuja 'centralidade' está exatamente no cidadão. Jay Rosen (apud TRAQUINA, 2003: 180) apresenta com clareza as intenções do jornalismo cívico:

(...) quebrar com velhas rotinas, um desejo de 'estar ligado do novo' com os cidadãos e as suas preocupações, uma ênfase na discussão séria como atividade principal na política democrática, e um foco nos cidadãos como atores do drama público em vez de espectadores.

Neste último caso, cabe ao jornalismo o agendamento de temas ligados aos direitos humanos e à democracia, em consonância com valores éticos e com a responsabilidade social da profissão.

Visto sob o ângulo da cidadania, jornalismo é o agendamento de temas socialmente relevantes em que o trabalho do emissor está pautado intencionalmente na difusão da notícia 'correta e plena' (Chaparro, 1994) capaz de conduzir o receptor a uma ação (Arendt, 1987) em nome da conquista e da preservação dos seus direitos civis, políticos e sociais (Marshall, 1967). 


\subsection{Do J ornalismo e da Cidadania no Brasil}

Em estudo publicado em sua primeira edição no início dos anos 70, Juarez Bahia (1990A) considera que o jornalismo brasileiro tenha se desenvolvido em quatro fases: a fase inicial (do início do século XIX até 1880), a fase de consolidação (de 1880 até a década de 1920), a fase moderna (dos anos 20 até meados dos anos 50) e a fase contemporânea (da segunda metade dos anos 50 a, aproximadamente, $1990^{12}$ ). Ainda que adotando o mapeamento do autor, ousamos incluir aqui uma nova etapa do desenvolvimento do jornalismo brasileiro. Este novo momento, que denominaremos fase das novas tecnologias (a partir dos anos 90), corresponde exatamente ao momento em que novos suportes e tecnologias de comunicação, como a TV a cabo e a internet, associam-se à vida e ao dia a dia da população brasileira.

Em sua fase inicial, que vai do início do século XIX a 1880, a imprensa brasileira é caracterizada por um jornalismo de opinião, às vezes mordaz, e de uma extrema militância política.

Apesar de algumas tentativas de implantação de tipografias no País a partir da segunda metade do século XVIII, elas ficaram oficialmente proibidas e muitas acabaram fechadas e empasteladas. Somente em maio de 1808, com a chegada da Família Real Portuguesa ao Brasil, são instaladas as oficinas e em setembro circula o primeiro jornal brasileiro: a Gazeta do Rio de Janeiro, sendo esse o marco inicial da imprensa nacional.

Nessa fase destacaram-se dois momentos na História da imprensa no Brasil. O primeiro deles foi a publicação do Correio Brasiliense, a cargo de Hipólito da Costa. O jornal, que começou a circular em junho de 1808, durou quase 15 anos e era impresso na Inglaterra, onde

\footnotetext{
${ }^{12} \mathrm{O}$ autor não delimita o final de seus estudos em 1990. A delimitação do período seguinte faz-se necessária como um recurso metodológico deste estudo.
} 
Hipólito vivia exilado. Graças ao Correio, que chegava clandestinamente no Brasil, Hipólito tornou-se patrono da imprensa brasileira.

O segundo marco é a produção, ainda que incipiente, de jornais e pasquins de cunho político e opinativo. As publicações eram identificadas com um líder, geralmente elevado a cargos públicos ou eclesiásticos, e cuja projeção social provavelmente não seria alcançada sem o jornal. Muitos dessas publicações apareciam associadas a questões nacionais - como a Proclamação da Independência e os embates da Constituição de 1824 - e tinham anseios políticos claros, inimigos declarados e muitas vezes estavam vinculados a causas sociais e ideais nacionais.

Em que pese a atuação de grandes jornalistas, como Hipólito da Costa e Cipriano Barata, que editou o Sentinela da Liberdade no início do século e engajou-se em lutas políticas, merece atenção nessa fase a atuação de Frei Joaquim do Amor Divino, o Frei Caneca, não só como jornalista que foi, mas especialmente como precursor de um pensamento jornalístico no Brasil.

Editor do Typhis Pernambucano e atuando com um jornalismo engajado, ferino e abertamente opinativo, Caneca esteve ligado a causas sociais em defesa do País frente aos interesses da Coroa Portuguesa, participando de movimentos como a Insurreição Pernambucana de 1817 e a Confederação do Equador, em 1824.

Os preceitos liberais, típicos das tendências iluministas e enciclopedistas que proliferaram na Europa do século XVIII e inspiraram a Revolução Francesa (e, na América, a Revolução Americana), marcaram o pensamento que sustentou o comportamento e a atuação política e jornalística de Caneca.

A preocupação com a formação da cidadania e com os direitos humanos - um dos principais pilares liberais - era tamanha que a partir da edição 24 do Typhis Pernambucano Caneca publicou, em forma de comunicado, um conjunto de trinta textos sob o título Bases para a 
Formação do Pacto Social redigidas por uma Sociedade de Homens de Letras. O material constitui um compêndio de condutas no qual defende os direitos humanos, a igualdade, a segurança e a propriedade; a resistência à opressão, o fim da escravidão, a soberania nacional e o direito do povo de rever a Constituição.

Essa preocupação, aliás, Caneca já trazia desde o primeiro número do Typhis quando criticava abertamente os atos do imperador (MELLO, 2001: 307):

É um direito natural e inalienável de qualquer cidadão, seja qual for a forma de governo em que se vive, o exame e o juízo dos fatos públicos, sem que sirva de égide a alguém a graduação, a classe, a hierarquia e a autoridade; e este direito é tanto mais sagrado quanto a ação praticada toca os direitos primários de um povo, de uma nação; e s. m. i. se acha tão penetrado desta verdade, que no dia 13 fez baixar o seu segundo decreto, em que declara que a qualificação de perjura, que o primeiro impôs à Assembléia Geral Constituinte e Legislativa, não deveria entender da 'totalidade da representação nacional do generoso povo brasileiro', sim da 'facção dominante do Congresso'.

Caneca foi mais que um teórico. Segundo Marcos Morel (2000: 75), a quem cabe o mérito de entender Caneca como precursor de um pensamento da comunicação brasileira:

Eleger (do latim, eligiere) e ler (legere) são duas ações de agrupar vontades e palavras. A expansão dessas prerrogativas era uma das características dos direitos do cidadão que, como se sabe, não eram universais nem no próspero Brasil da escravidão nem nas monarquias européias liberais ou absolutistas. Frei Caneca não pregava apenas, também assumia ele mesmo, em sua prática pessoal, a ampliação dessa cidadania. Argonauta enfrentando o contexto bravio de um novo Império ainda marcado pelas práticas do Antigo regime.

No final do século XIX começaram, nos institutos históricos nacionais, as pesquisas sobre o jornalismo brasileiro. José Marques de Melo (1985: 58) observa que foram "(...) os resultados das investigações realizadas por Moreira de Azevedo, Max Fleiuss, Vale Cabral, Alfredo de Carvalho, Barão de Studart, Craveiro Costa, Afonso de Freitas e tantos outros que resgataram o desabrochar da nossa 
imprensa e suas transformações". Esse momento coincidiu com o início da fase de consolidação da imprensa nacional, que vai do final do século $\mathrm{XIX}$ até os anos 20 do século $X X$.

Esse foi o momento em que os jornais começaram a se firmar como empresas jornalísticas e o caráter de pasquim opinativo foi gradativamente substituído por uma lógica institucional e comercial. Saiu de cena a tipografia artesanal e a indústria passou a ocupar seu espaço (BAHIA, 1990A: 105):

\begin{abstract}
A segunda fase da imprensa brasileira começa em 1880, setenta e dois anos passados da instalação do pesado material de impressão da Gazeta do Rio de Janeiro. É um tempo de aventura industrial mais investimentos, renovação do parque gráfico, maior consumo de papel - que abre ao jornal a dimensão de empresa.

Depois de 1880, notadamente em fins do século XIX e começo do século $\mathrm{XX}$, a imprensa está preparada para o estágio empresarial como ocorre em países mais avançados. Nesse espaço, os novos jornais trazem com seus títulos que se tornarão importantes, experiências e objetivos próprios das organizações industriais.
\end{abstract}

Nessa fase surgiram grandes jornais brasileiros, como o J ornal do Brasil (1891), no Rio de Janeiro. Muitos deles se associaram a grandes causas nacionais, como a Abolição da Escravatura e a Proclamação da República. Em 1908 foi fundada e ABI - Associação Brasileira de Imprensa - e, no primeiro Congresso da entidade, em 1918, o seu então presidente, João Guedes de Melo, já propunha a criação de uma Escola de Jornalismo tomando como referência os moldes norteamericanos.

A fase moderna da imprensa brasileira tem início nos anos 20 e se estende até meados dos anos 50. Surgiram na época O Globo, no Rio de Janeiro, e a Folha de S. Paulo (então Folha da Manhã), em São Paulo). Apareceram também os Diários e Emissoras Associados, tendo à frente o paraibano Assis Chateaubriand. Suas empresas constituíram, entre os anos 30 e 70, uma cadeia de comunicação até então sem precedentes no Brasil e na América Latina. 
Nessa fase de expansão das empresas de comunicação e de jornalismo desenvolveu-se um know-how jornalístico sob forte influência da indústria norte-americana. A crescente e já sólida urbanização do País, o aumento do poder de compra da população, os maiores índices de educação e as agitações políticas, como a Revolução de 30, constituíram um cenário plausível para o desenvolvimento das cadeias de comunicação, fosse no jornalismo impresso ou no rádio.

Especialmente após a Segunda Guerra Mundial, a publicidade passou a ocupar um lugar de destaque na imprensa, o que fomentou o caráter mercantilista e econômico da atividade. Assim, cresceram também a compra de informações das agências de notícias internacionais e a atuação de agências nacionais de publicidade.

Num primeiro momento (até meados dos anos 40), despontam como pensadores do jornalismo local nomes como Rui Barbosa e Barbosa Lima Sobrinho.

Jornalista atuante no embate político e social do País dos primeiros anos do século XX, Rui Barbosa (1849-1923) é uma importante referência quando a imprensa e o jornalismo brasileiro, suas questões éticas e função social são discutidos.

Em A Imprensa e o Dever da Verdade, de 1920 e um de seus textos clássicos, o autor, movido por um forte nacionalismo, observa que ao invés de um jogo de interesses privados, o jornalismo brasileiro deveria representar um compromisso público com a Nação e com seu povo (2003: 22):

\begin{abstract}
A imprensa é a vista da nação. Por ela é que a Nação acompanha o que lhe passa de perto e ao longe, enxerga o que lhe mal fazem, devassa o que Ihe ocultam e tramam, colhe o que lhe sonegam ou roubam, percebem onde the alvejam, ou nodoam, mede o que the cerceiam, ou destroem, vela pelo que lhe interessa, e se acautela do que a ameaça.
\end{abstract}

Barbosa Lima Sobrinho (1897-2000) constitui também uma referência para a apreensão do jornalismo nacional. Em O Problema da 
Imprensa, de 1923, ele assinala as preocupações e implicações éticas do jornalismo como norte das suas atenções como estudioso e "homem de imprensa". Defensor do ensino do jornalismo, Sobrinho pondera em seu livro (2003: 187-188):

Há defeitos na imprensa incorrigíveis e diante dos quais é preciso cruzar os braços, pelo receio dos danos imensos que qualquer intervenção acarretaria. Esclareça o espírito público, difunda-se a instrução e entregue-se à educação o preparo de caracteres; à medida que esse esforço venha atuando, a imprensa naturalmente se elevará.

(...)

No dia em que o jornalista tiver a noção completa de sua responsabilidade e de sua atuação social, provavelmente se sujeitará a normas escrupulosas de ética.

A partir dos anos 50, a radiodifusão está consolidada no País. Ao rádio, que ocupara lugar de destaque na Era Vargas (1934-1945), vem somar-se a televisão. Com a concorrência, os jornais são obrigados a reestruturar-se e se transformam, definitivamente, em empresas de produção em massa.

No final dos anos 40, aparecem as primeiras faculdades de Jornalismo. Primeiro em São Paulo, com o curso da Escola de Jornalismo Cásper Líbero; em seguida no Rio de Janeiro, com o curso da Universidade do Brasil, atual Universidade Federal do no Rio de Janeiro.

Nos anos 50, com uma proposta editorial e gráfica inovadora, surge o jornal Última Hora, de Samuel Wainer, ex-repórter de Chateaubriand. Mais adiante, em 1965, dá-se um marco para a indústria da comunicação e do jornalismo brasileiro: é inaugurada a Rede Globo de Televisão, do grupo do jornal O Globo ${ }^{13}$.

Entre os anos 50 e meados dos anos 60, o jornalismo doutrinário dos anos anteriores perde definitivamente lugar para um jornalismo cada vez mais preocupado com o mercado (os anunciantes e o público).

\footnotetext{
${ }^{13}$ Até hoje as Organizações Roberto Marinho (Globo), tendo como carro-chefe a TV, constituem uma das maiores experiências em conglomerado de mídia no mundo todo.
} 
Alceu Amoroso Lima, Carlos Lacerda, Luiz Beltrão e Danton Jobim vão refletir sobre a atuação do jornalismo brasileiro nesse cenário.

Ao longo de sua vida Alceu Amoroso Lima (1893-1983) foi administrador, crítico literário, educador, atuou no cenário político nacional e teve grande prestígio na I greja Católica. Versátil, Tristão de Athayde - pseudônimo que usava no início da carreira de jornalista, em 1919 - dedicou parte de sua vida a estudos de temas e conceitos sociais.

Em um dos seus textos, O Jornalismo como Gênero Literário, escrito no final dos anos 50 e refletindo valores e desse período, Amoroso Lima deixa transparecer justamente essa veia, preocupado que está mais em entender a natureza e o alcance político do jornalismo do que propriamente discuti-lo no âmbito da literatura (2003: 76):

E como nem a poesia, nem o romance, nem o teatro, nem a crítica,
nem a biografia, nem qualquer das artes de comunicação deixa de
ser hoje influenciadas pelo espírito jornalístico dominante em nossos
dias, ou sobre eles influi - bem podemos avaliar o peso da
responsabilidade que cai sobre os verdadeiros jornalistas de
vocação, ou apenas de profissão, e sobre o jornalismo em si, como
uma arte, como uma arma e como uma forma de educação do
homem e da Opinião Pública.

Em 1949 o polêmico jornalista e político Carlos Lacerda profere, na $A B I$ do Rio de Janeiro, uma palestra que origina o livro A Missão da Imprensa. O texto é influenciado pelo pensamento ético-jornalístico de Rui Barbosa e Amoroso Lima. Mas, mais do que teorizar sobre o assunto, o livro deixa transparecer a inquietação pessoal do autor com as práticas jornalísticas vigentes (2003: 27):

Da imprensa, já dizia Rui Barbosa, ao qual tantas vezes recorrerei, que era 'a vista da Nação'. E dizia também que pela imprensa a nação respira. Como também pela imprensa ouve e fala a nação, temos que o jornalismo é os olhos, a boca e - ai de nós - algumas vezes até o nariz da nação.

(...) 
Ver sem cessar de ver, e dizer incessantemente o que vê, é o seu modo (do jornalista) de construir. Não se exige do carpinteiro que levante paredes, do pedreiro não se espera que empalhe cadeiras. Pois do jornalista não se exija que construa senão aquilo que lhe é próprio construir: uma opinião pública bem informada, atenta, vigilante, esclarecida.

Professor de jornalismo, Luiz Beltrão (1918-1986) tem sua marca na historiografia da imprensa brasileira como o criador do conceito da Folkcomunicação. No entanto, uma importante reflexão sobre o papel e a natureza jornalística encontra-se em Iniciação à Filosofia do Jornalismo, cuja primeira edição data de 1960.

A noção de ética e de responsabilidade do jornalismo permeia a obra, que reconhece a atividade da imprensa compromissada com o bem comum (2003: 67):

(...) jornalismo é a informação de fatos correntes, devidamente interpretados e transmitidos periodicamente à sociedade, com o objetivo de difundir conhecimentos e orientar a opinião pública, no sentido de promover o bem comum.

Finalmente, em 1966 Danton Jobim (1906-1978) publica Espírito do J ornalismo. Parte da obra dedica-se a discutir a formação e o ensino do jornalismo na época. No entanto, a idéia do compromisso e da responsabilidade social, muitas vezes negligenciada pela imprensa, perpassa a compreensão que o autor tem do 'espírito do jornalismo' (2003: 68):

O povo ainda não perdeu a fé na sua imprensa. No Brasil, quando trabalhadores ou estudantes se consideram ameaçados dos seus interesses ou ameaçados nas suas esperanças, nem sempre se dirigem a seus patrões ou às autoridades universitárias, mas 'vão ao jornal'. Quando alguém tem uma queixa relativa a um serviço público ou sofre uma injustiça, volta suas vistas não para os homens do governo, mas para o jornal, a que o povo humilde empresta a missão de vingador de ultrajes e paladino de nobres causas.

$\mathrm{Na}$ mente popular, o jornal tem um destino heróico a cumprir. Em sua ingênua concepção, jornalismo não é um negócio, mas a empresa de um campeão permanentemente em guarda contra a iniqüidade. 
A marca do início da fase contemporânea da imprensa brasileira, que segundo Bahia (1990A) dá-se a partir de meados dos anos 50, é a consolidação da TV como veículo de comunicação no Brasil. O momento marcante dessa etapa é o desenvolvimento do jornalismo eletrônico, especialmente a partir de 1965, na Rede Globo de Televisão.

Esse momento coincide com o início do regime militar (19641985) e os veículos de informação funcionaram não apenas como retificadores dos valores de uma sociedade cada vez mais urbana como também serviram para desviar a atenção da população para as grandes questões políticas da época.

A censura militar, especialmente até 1979, atuou pesadamente sobre o jornalismo. O Al-5, decretado em 1968, não só limitou a liberdade de imprensa como também confiscou direitos civis dos brasileiros. Cidadãos e jornalistas foram silenciados, perseguidos e, em muitos casos, mortos.

Ao mesmo tempo, na fase contemporânea da imprensa nacional consolidaram-se as faculdades de Comunicação Social e os cursos de Jornalismo e, a partir do final dos anos 70, o diploma de curso superior passou a ser obrigatório para o exercício da profissão ${ }^{14}$. Desenvolveu-se também a produção de intelectuais de centros de pesquisas. Apareceram a INTERCOM - Sociedade Brasileira para Estudos Interdisciplinares da Comunicação -, a ABEPEC - Associação Brasileira de Ensino e Pesquisa da Comunicação, - a ABECOM - Associação Brasileira de Escolas de Comunicação -, e a COMPÓS - Associação Nacional dos Programas de Pós-Graduação.

Enfatizando a historiografia do jornalismo brasileiro, Marques de Melo (1983: 08) observa que, em todo o mundo, apesar de quase dois séculos de estudos, esse tempo não se mostrou bastante para imprimir ao jornalismo uma precisão conceitual. Para ele:

\footnotetext{
${ }^{14}$ Não obstante, a partir de 1986 começam a tramitar em instâncias jurídicas do Governo Federal projetos de suspensão da obrigatoriedade do diploma.
} 
A justificativa não está apenas na circunstância de que são fenômenos sociais e, portanto dinâmicos, mas na essência mesma do jornalismo que se nutre do efêmero, do provisório, do circunstancial, e por isso exigem do cientista maior argúcia na observação e melhor instrumentação metodológica para que não caia nas malhas do transitório.

Nos anos 90 tem início a fase das novas tecnologias aplicadas ao jornalismo brasileiro. Se os primeiros anos do século $\mathrm{XX}$ marcaram o aparecimento e o aprimoramento dos meios de comunicação, sobretudo da mídia eletrônica, o novo século parece apontar para o aumento quantitativo das tecnologias virtuais. Mas esse desenvolvimento quantitativo nem sempre vem acompanhado de uma evolução qualitativa dos compromissos da imprensa com a cidadania.

Nesse sentido, muitos teóricos da atual fase de estudos da comunicação e do jornalismo - e, de resto, de todas as áreas das ciências sociais e humanas - têm revelado preocupações.

Pedro Celso Campos (2001) reflete sobre o papel destinado ao jornalista nesta nova fase:

(...) nos meios acadêmicos debate-se o papel do produtor de notícias dentro do contexto empresarial dos meios de comunicação. Num mundo eletronicamente globalizado, onde textos e imagens digitalizadas viajam vertiginosamente em torno do planeta através dos satélites e das fibras óticas, sendo "decodificadas" na outra ponta através das mais variáveis interfaces que tanto podem ser um minúsculo telefone celular, como uma enorme impressora de jornal comandada à distância, ou ainda um monitor de TV ou de computador, ou um aparelho de rádio, pergunta-se qual o espaço que sobra, afinal, para o jornalista, para o profissional encarregado de produzir, processar e emitir o discurso. Um discurso que já não pode ser meramente informativo porque também precisa ser interpretativo. Um discurso que envolve a necessidade de opinar porque este é um dever do comunicador que deseja prestar serviço ao receptor. Um discurso que não pode descuidar, ainda, da sua finalidade lúdica, enquanto texto "recreativo" para amenizar o stress desse náufrago cercado de informação por todos os lados que é o homem do século XXI.

Em detrimento às preocupações com as técnicas e as tecnologias do jornalismo, a responsabilidade social, a ética da profissão e sua 
relação com a cidadania brasileira têm ocupado lugar de destaque nas pesquisas e nos eventos sobre comunicação e jornalismo do País. Também têm sido, gradativamente, abertos espaços de diálogo entre pensadores do jornalismo brasileiro e intelectuais de comunidades internacionais, a exemplo de países como Canadá, Portugal e Moçambique.

$\mathrm{Na}$ atual fase despontam, especialmente nas escolas do Sul e Sudeste do Brasil, importantes nomes do pensamento jornalístico nacional. Aparecem também outros núcleos acadêmicos, não só no Sudeste, mas também no Sul, no Centro-Oeste e no Nordeste do País.

Estudiosos como Nilson Lage (2003), da Universidade Federal de Santa Catarina, têm enfatizado a responsabilidade social do jornalismo e, atrelada a ela, a necessidade de formação do profissional:

O interesse (pela formação profissional do jornalista) é do povo e, embora essa palavra esteja em desuso na sua anterior nobreza, da pátria. Na sociedade da informação, não importa apenas dispor de canais: é necessário produzir conteúdos claros, éticos e honestos. 0 desenvolvimento de padrões técnicos elevados, a expansão do jornalismo de qualidade a todo território do país, a instalação de sucursais e correspondentes no exterior são questões que envolvem a auto-estima da população das diferentes regiões, a perpetuação da cultura e da soberania nacionais, com as variedades que ela comporta; um conjunto de fatores que nos permitirá, algum dia, ver a nós mesmos e ao mundo com a perspectiva brasileira. Na sociedade globalizada, um jornalismo de má qualidade submergirá no mar de discursos imperiais e de valores homogêneos que se difundem com competência. 


\subsection{Da Ética e da Responsabilidade Social do J ornalismo}

Embora no início do século passado Rui Barbosa já chamasse atenção para os compromissos da imprensa nacional com o povo brasileiro, estudos recentes ainda se preocupam em desnudar e discutir posturas socialmente pouco responsáveis da mídia e do jornalismo no Brasil. Algumas instituições têm elaborado um mapeamento da atuação da imprensa e assim discutido e apontado novas perspectivas para o jornalismo brasileiro.

As atividades de ombudsman e a criação de espaços (como programas de TV e sites) que discutem o jornalismo são uma prova da tentativa de construir-se um novo caminho em que esteja em pauta a responsabilidade social da comunicação.

Ainda assim, não são poucos no Brasil os programas de rádio e televisão, os sites e as publicações impressas de conteúdo jornalístico que se arvoram e se apresentam como arautos da cidadania e defensores do cidadão. Nas redes nacionais, tecidas por mega-cadeias de comunicação, ou mesmo nos mais longínquos programas e publicações locais, a cidadania tornou-se lugar-comum. Abreviando a discussão do tema, esses programas têm negligenciado o próprio conceito, limitando a cidadania a elementos de espetacularização da informação, favorecimentos de toda sorte - políticos, econômicos etc. - e achaques à condição humana.

Um estudo realizado por Eduardo Rocha Marcos (2002: 48) em 1998 sobre o discurso televisivo do SP-TV Primeira Edição, da Rede Globo de Televisão / São Paulo, especialmente sobre o quadro SP Desafio, voltado para a promoção da 'cidadania', é bastante ilustrativo da questão. O autor observa que o discurso não funciona como conscientizador na medida em que é voltado para o espetáculo e solidifica-se na questão lúdica: 
(...) o telejornal trabalha determinadas reportagens com fidelidade ao seu objetivo declarado e, por vezes, supera-se, indo além da sua proposta, por exemplo, quando deixa de ser um intermediador e passa a ter o duplo poder de intermediar / fiscalizar.

No entanto, quando sua preocupação é tornar leve e massificar um discurso complexo, como o discurso da cidadania, seu objetivo se perde na preocupação do show, do espetáculo, da banalização e inconsistência.

Em programas desse tipo, a cidadania aparece mais como um gancho para o espetáculo, o favor e o achaque. Ela não aparece como um instrumento político de conquista de direitos e entendimento de deveres, como o nosso modelo de jornalismo cidadão, com base nos conceitos de Marshall (1967), Arendt (1987) e Chaparro (1994), pressupõe que deva acontecer.

Um exercício profissional ético e socialmente responsável, pautado nos direitos humanos e na democracia, é fundamental para uma realização cidadã da atividade jornalística.

Para o filósofo alemão Immanuel Kant (1724-1804), a ação humana deve ser conduzida por um 'imperativo categórico'. Isto é, a ação ética não se condiciona a interesses pessoais, mas ao bem coletivo. Para Kant, segundo Eugênio Bucci (2000: 22):

(...) uma regra de conduta só pode ser aceita ser for universal, isto é, se tiver validade tanto para o agente como para todos os outros seres racionais. A conseqüência do ato já não importa. O que importa é que o ato se revista das características de um imperativo categórico universal, quer dizer, que o ato se apóie em princípios que tenham a mesma validade para todos.

É, portanto, exatamente essa ética kantiana, que considera os direitos humanos e a democracia, que interessa ao jornalismo. Nas palavras de Bernardo Kucinsky (2004):

E por que a ética kantiana se aplica ao jornalismo? Porque se o jornalista começa a ponderar sobre as conseqüências das verdades que tem a dizer, sobre a conveniência de revelar parte da verdade e omitir outra, começa a assumir um outro papel social - deixa de ser jornalista para ser um censor e um juiz daquilo que o povo deve ou não deve saber. Na ética kantiana, não cabe esse julgamento. 
Ética jornalística implica, pois, em responsabilidade social. No Brasil, o atual Código de Ética dos Jornalistas Brasileiros (anexo 02), em vigor desde 1987, ilustra esses conceitos, que são claramente contemplados nos trechos que transcrevemos a seguir:

Art. 30 - A informação divulgada pelos meios de comunicação pública se pautará pela real ocorrência dos fatos e terá por finalidade o interesse social e coletivo (GRIFO NOSSO).

(...)

Art. 60 - O exercício da profissão de jornalista é uma atividade de natureza social e de finalidade pública (GRIFO NOSSO), subordinado ao presente Código de Ética.

(...)

Art. 70 - O compromisso fundamental do jornalista é com a verdade dos fatos, e seu trabalho se pauta pela precisa apuração dos acontecimentos e sua correta divulgação (GRIFO NOSSO). (...)

Art. 16. O jornalista deve pugnar pelo exercício da soberania nacional, em seus aspectos político, econômico e social, e pela prevalência da vontade da maioria da sociedade, respeitados os direitos das minorias (GRIFO NOSSO). 


\title{
CAPÍ TULO III
}

\section{Da Cidadania \\ e da Formação do J ornalista no Brasil}

\begin{abstract}
A instrução será orientada no sentido do pleno desenvolvimento da personalidade humana e do fortalecimento do respeito pelos direitos do homem e pelas liberdades fundamentais. A instrução promoverá a compreensão, a tolerância e amizade entre todas as nações e grupos raciais ou religiosos, e coadjuvará as atividades das Nações Unidas em prol da manutenção da paz.

Parágrafo II do artigo XXVI da Declaração Universal dos Direitos Humanos
\end{abstract}

"A imprensa educa, ensina, dirige e inspira", dizia Barbosa Lima Sobrinho (2003: 26) na primeira metade do século XX. E esse compromisso do jornalismo com a educação e com a cidadania ele tende a cumprir melhor à medida que os jornalistas são também melhor formados. Aliás, para Marshall (1967), vale lembrar, a educação é um pré-requisito para a liberdade civil. Carvalho (2003: 11) também observa que a educação

(...) é definida como direito social, mas tem sido historicamente um pré-requisito para a expansão dos outros direitos. Nos países em que a cidadania se desenvolveu com mais rapidez, inclusive na Inglaterra, por uma razão ou por outra a educação popular foi introduzida. Foi ela que permitiu às pessoas tomarem conhecimento dos seus direitos e se organizarem para lutar por eles. A ausência de uma população educada tem sido sempre um dos principais obstáculos à construção da cidadania civil e política.

Para discutir a formação do jornalista brasileiro, Jaci C. Maraschin (MARQUES DE MELO; FADUL, 1979) observa, com base em Aristóteles, 
que a "formação" é a abertura do indivíduo para a realização do seu potencial. Por outro lado, do mesmo modo que a esse indivíduo é facultada a possibilidade de abrir-se à "forma" (à formação), essa abertura também está sujeita à ameaça da "deformação".

Tomando como referência uma abordagem marxista, Maraschin considera que hoje a formação profissional está inserida no âmbito do mercado, "um âmbito alienador e alienante". Portanto, essa formação é contraditória na medida em que o profissional "realmente formado, só pode ser aquele que critica essa realidade que se Ihe afigura alienadora" (MARQUES DE MELO; FADUL, 1979: 135-136). E continua:

Daí a importância da profissão na sociedade humana. Nela o homem desenvolve suas possibilidades criadoras e se transforma no que deveria ser. É por isso que, na atual sociedade, o homem só se realiza plenamente na medida em que se transforma em profissional. Forma-se profissionalmente significa, então, abrir-se para a sociedade num processo livre de criatividade e serviço.

O contrário disso, para o autor, é a mera transmissão de informação e implica numa deformação:

Ao submetermo-nos às regras do mercado alienador, pura e simplesmente, abandonando a riqueza e o poder da 'formação', criamos servos da situação vigente. Recortamos sobre o cenário do servilismo profissionais que se encerram em especializações e exercem suas funções de maneira egoísta. Procuram nelas mais a segurança pessoal do que o desenvolvimento equilibrado da vida comunitária. Formar-se, nessa perspectiva, passa a significar informar-se: adquirir os conhecimentos necessários para dominar situações, manipular dados, decifrar códigos, para também dominar pessoas, manipular grupos e impor-se como aquele que sabe.

Mas é exatamente no contexto do mercado que tem início a formação profissional do jornalista norte-americano e que serviu de inspiração ao modelo brasileiro. Segundo Carlos Rizzini (1953: 5), ainda que tenha havido tentativas desde meados do século XIX quando, em 1869, o reitor do Washington College (Lexington), Richard Lee, propôs a criação de cursos superiores na área, foi no início do século XX que surgiram as primeiras escolas de Jornalismo nos Estados Unidos. 
Inicialmente a imprensa apresentou resistência aos novos cursos, mas um artigo publicado em 1904 por Joseph Pulitizer - The College of Journalism - e a crescente necessidade de profissionalização da imprensa por conta de uma demanda de informação jornalística agora como mercadoria, abriram os caminhos necessários para a formação.

Em 1908 apareceu a Escola de Jornalismo de Missouri, na cidade de Columbia, e mais tarde a Escola de Jornalismo de Columbia, em Nova Iorque, em 1912. Mas foi a década de 20 que marcou um período de franca expansão do ensino de Jornalismo na América.

Nesse momento despontaram os estudos com base nas teorias da recepção, que buscaram apreender o fenômeno da comunicação e a maneira como se dava sua influência sobre o público. Esse foi, afinal, um período de acelerado desenvolvimento da cultura e da sociedade de massa. Nos Estados Unidos, Hollywood sedimentava-se, com o cinema, como grande produtora cultural e surgiam as grandes corporações comunicacionais.

A partir daí, nos diversos continentes, ao longo do século $X X$, eclodiram escolas, pesquisas e estudos sistemáticos destinados a lançar luzes sobre o fenômeno da comunicação.

Do início do século $X X$, quando a profissão de jornalista começou a adquirir identidade e status social no Brasil, até o final dos anos 40, o aprendizado do jornalismo era extremamente precário e funciona à revelia da academia. As primeiras escolas de Jornalismo aparecem apenas em meados do século. Primeiro, em 1947, com o curso da Escola de Jornalismo Cásper Líbero, em São Paulo, conveniado com a Faculdade de Filosofia, Ciências e Letras de São Bento, da Pontifícia Universidade Católica de São Paulo. Em seguida, em 1948, com o curso da então Universidade do Brasil (atual Universidade Federal do no Rio de Janeiro), inserido na Faculdade de Filosofia da instituição.

No entanto, algumas experiências já haviam sido realizadas. Em 1937 ocorreu uma experiência pioneira na Universidade do Distrito 
Federal (UDF, desativada em 1939), no Rio de Janeiro. Ali foi implantada, tendo à frente a figura do jornalista Costa Rego (18891954), a primeira cátedra de ensino de Jornalismo do País. A esse respeito, Marques de Melo observa (2003: 295):

(...) registrou-se a criação da primeira Cátedra de Jornalismo do Brasil na Universidade do Distrito Federal, instalada na cidade do Rio de Janeiro. Trata-se de um projeto efêmero, desarticulado precocemente durante a ascensão do ciclo autoritário liderado por Getúlio Vargas, mais conhecido historicamente como Estado Novo. Essa cátedra precursora dos estudos universitários de Jornalismo foi confiada ao jornalista Costa Rego, então prestigiado secretário de redação do jornal carioca Correio da Manhã, um dos principais formadores de opinião pública no país.

Além dessa experiência, a preocupação com a formação do jornalista foi questão central do trabalho de Vitorino Prata Castelo Branco (1904-1994). A obra Curso de Jornalismo (1945: 17), de 1945, foi produto de aulas proferidas pelo autor. O curso, dividido em doze lições, tem uma proposta autodidática e, ainda que enfatizando as técnicas do jornalismo, aponta para a necessidade de o jornalista assimilar as implicações éticas da profissão:

Este curso tem por objeto desenvolver aptidões jornalísticas ente alunos já inclinados aos trabalhos da imprensa, encaminhado os seus desejos para as tarefas já imediatas da profissão, propagando, entre eles, ao mesmo tempo - 'sentimentos cívicos e normas de ética jornalística, para que possam exercer a sua atividade eficaz e dignamente'.

Embora uma das grandes contribuições de Carlos Rizzini apareça na obra O livro, o jornal e a tipografia no Brasil, 1500-1822: um breve estudo geral sobre a informação, publicada em $1946^{15}$, ele também atuou como professor de Jornalismo e publicou, em 1953, o pequeno livro O Ensino do Jornalismo (1953: 56). Nele, defende a formação do jornalista não só do ponto de vista cultural, mas também dá especial ênfase ao "treino profissional":

\footnotetext{
${ }^{15}$ Neste trabalho, é reputado ao autor o mérito de produzir uma obra pioneira na moderna bibliografia de comunicação que serve, até hoje, como referência histórica e analítica para discussões do tema.
} 
Os jornais, mesmo sem colaborar com o Curso, terão de reconhecer a superioridade de um jornalista culto. Certamente, não o recusarão por isso. Mas, sem dúvida, o preterirão se ele não souber passar para o papel a sua cultura. Repetimos: nada adianta saber como se faz o jornal - é preciso saber fazêlo.

O ensino superior de Jornalismo no Brasil acabou de completar cinqüenta anos no final do milênio. De lá para cá muita coisa mudou e evoluiu, sobretudo, as técnicas que envolvem a profissão. Não é difícil, aliás, argumentar a questão frente aos disparates entre a tipografia e a impressão em offset e, mais recentemente, o auxílio prestado pela editoração eletrônica e pelo compute-to-plate ${ }^{16}$ aos processos de reprodução de materiais impressos, sem contar com os recursos do jornalismo on-line.

Se por um lado discutem-se, na sociedade e na mídia, os elementos conceituais e éticos da atividade jornalística, um dos temas mais freqüentes na academia desde o início dos cursos de Jornalismo diz respeito não só à natureza e à responsabilidade da profissão, mas também à formação acadêmica dada ao profissional da imprensa.

Ao final de mais de meio século de formação superior de jornalistas no Brasil discute-se, e com muita razão, a viabilidade, o formato e a função desses cursos.

\footnotetext{
${ }^{16}$ Nos últimos dez anos os jornais conquistaram avanços tecnológicos que facilitaram sua produção. Os sistemas CTP (compute-to-plate) possibilitaram economia de tempo e qualidade final ao produto impresso.
} 


\subsection{Das Quatro etapas do Ensino de Jornalismo no Brasil}

Para melhor discutirmos o ensino da Comunicação Social e do Jornalismo no Brasil, adotaremos um esquema proposto por Marques de Melo em 1972 (RAMADAN, 2000: 34) e atualizado recentemente pela professora Nancy N. Ali Ramadan (2000). Assim, podemos dividir a formação do comunicador em quatro etapas. A primeira, que vai de 1946 a 1960; a segunda, de 1961 a 1969; a terceira, de 1969 até meados dos anos 80 e, finalmente, a quarta e atual fase.

José Salomão Amorim (apud LAGE, 1985: 08) identifica e caracteriza bem as duas primeiras fases no ensino da Comunicação no Brasil. Na primeira, que vai do final dos anos 40 até o início dos 60, predominava nas escolas um enfoque europeu, baseado em disciplinas e conteúdos reflexivo-filosóficos. Para o autor, o estudante de Jornalismo tendia a sair da faculdade com uma formação notadamente humanística, característica das faculdades de Filosofia a que o curso era atrelado.

Neste primeiro momento, em 1959, surgiu o CIESPAL - Centro Internacional de Estudios Superiores de Comunicación para América Latina -, com sede no Equador, com relevantes pesquisas para o ensino e para a prática da comunicação no continente.

$\mathrm{Na}$ fase seguinte, Salomão enfatiza a conotação técnica da formação, inspirada nos moldes norte-americanos. Desenvolve-se a partir de finais dos anos 60, como reflexo do fortalecimento da indústria cultural norte-americana depois da Segunda Guerra Mundial.

No Brasil, com a criação do curso de Jornalismo como uma habilitação de Comunicação Social, a partir de 1969 - estimulado pelo rápido e intenso desenvolvimento das tecnologias de comunicação - o ensino técnico das habilidades profissionais passou a ganhar destaque. Neste momento a formação profissional do jornalista passou a ser reconhecida (1969). 
$\mathrm{Na}$ terceira fase a formação profissional do jornalista tornou-se obrigatória para o exercício da profissão (final da década de 70), correspondendo ao momento de regulamentação profissional.

Em 1972, foi fundada em evento realizado na Universidade de São Paulo, a primeira entidade acadêmica de estudos da comunicação. Trata-se da ABEPEC - Associação Brasileira de Ensino e Pesquisa da Comunicação. Apesar da vida curta (durou até 1985), abriu portas para a formação de outras associações que até hoje têm desenvolvido pesquisas na área.

A quarta fase é apresentada e caracterizada por Ramadan (2000: 36):

Podemos falar de uma quarta fase, já que tempo e espaço ganham novos contornos e o ritmo global impõe atualização similar ao ritmo de criação de novos softwares. Essa quarta fase tem início em 90, quando a universidade começa a incorporar estas novas tecnologias com maior intensidade, sem amadurecer um projeto pedagógico que relacione nas instâncias prática e teórica as mutações que a profissão vem sofrendo, bem como o ensino de jornalismo.

Para a autora,

É nesta quarta fase que podemos observar a quase que total despreocupação dos docentes com o ensino de jornalismo em seu aspecto filosófico. Aparentemente, as 'facilidades' técnicas para a produção de material jornalístico e a velocidade embutidas na nova paisagem tecnológica dariam conta de tudo: não seria necessária uma reflexão no campo da filosofia da Educação, bastaria dominar o aparato técnico.

A partir de 1996, por determinação do Ministério da Educação, os alunos formandos pelos cursos de Jornalismo passaram a integrar a lista de avaliados pelo Exame Nacional de Cursos que, a partir de 2004, ganhou um novo formato.

Ao mesmo tempo, junto às comunidades acadêmicas se desenvolveram instituições autônomas de estudos da comunicação e do jornalismo. Muitas delas, aproveitando a disponibilização de espaço 
oferecido pelas novas tecnologias, ocuparam a internet como um fórum permanente de discussões. A exemplo, o site Observatório da Imprensa, tendo à frente o professor e jornalista Alberto Dines, tem funcionado com um importante espaço para a repercussão e discussões da profissão.

Se, por um lado, a fase atual é um momento em que ao jornalismo somam-se as novas tecnologias de informação, o desejável seria que ela fosse também marcada por uma interação entre essas tecnologias e as ciências sociais e humanas na formação dos profissionais de jornalismo.

Mas não é isso que Ramadan (2000: 210) conclui a partir da sua recente pesquisa:

Os docentes da área de comunicação responsáveis pelo seu ministério, mais especificamente de jornalismo, prescindem de formação que ofereça elementos pedagógicos que dêem conta da prática jornalística em seu novo cenário. Mais que isso, necessitam de formação que possibilite a articulação entre a teoria e a prática jornalísticas na nova paisagem que se apresenta.

Reverter esse quadro exigiria que este docente se colocasse na posição de aluno, de estudante, aberto para a reflexão. Porém, num cenário regido pela lógica global do resultado imediato, da eficiência econômica, os docentes tendem a buscar na técnica, de forma equivocada, referenciais que dificilmente contemplaria. Senão, vejamos: apenas $38 \%$ dos professores consideram a articulação teoria / prática fundamental.

A formação humanística que nos primeiros anos marcou o jornalismo engajado de muitos profissionais foi sendo gradativamente substituída - inclusive nos currículos - pela busca e pelo aperfeiçoamento de técnicas de produção e edição da notícia em vídeo, rádio, veículos impressos e, mais recentemente, na mídia on-line.

Esse panorama acaba servindo muito bem como um fio condutor para compreendermos porque muitos profissionais da comunicação reproduzem não só o formato e as técnicas jornalísticas, mas também conceitos ideológicos e políticos dominantes. 
O tecnicismo característico das últimas etapas parece ter ganhado força nos últimos anos. Num texto que analisa a relação (ou sua falta) entre os intelectuais e a sociedade brasileira, Cristovam Buarque (VERÍSSIMO, 2000: 93) observa:

Em 1985, como o fim da ditadura, os intelectuais conseguiram vencer os obstáculos à liberdade, mas se surpreendem com a letargia com que se deparam. O mundo entrou simultaneamente em crise de valores: o caminho da justiça, a forma da liberdade e o conceito de riqueza passaram a ser questionados. Nos países ditos desenvolvidos, muitos intelectuais criticavam o conceito de liberdade individual e seu poder destruidor; nos países socialistas, cresciam os reparos à forma como a justiça social era imposta, submetendo a liberdade individual. No mundo inteiro a crise ecológica forçava uma luta por um novo conceito de riqueza, capaz de levar em conta o meio ambiente. Viu-se que não bastava lutar por um mundo mais rico e com esta riqueza melhor distribuída: passou a ser necessário reformar o próprio conceito de riqueza. Morreu um paradigma, não nasceu um novo, e os intelectuais não aceitaram viver a aventura de romper os círculos que o aprisionavam. Conformaram-se com o mundo em que bastava o avanço técnico para ampliar a riqueza tradicional, independentemente de sua beleza e de sua justiça.

Com base no pensamento de Maraschin (MARQUES DE MELO; FADUL, 1979), entendemos que formar um indivíduo no âmbito da Comunicação Social é, antes de tudo, formar um ser humano e social que deve, na sua condição humana, ter possibilidade de refletir sobre a sua sociedade. Para isso, ele deve estar bem amparado pelas ciências humanas e sociais e, mais que isto, na análise e no posicionamento crítico da realidade.

É claro, existem muitos bons jornalistas e comunicadores com um senso crítico aguçado e amadurecido. E existem também excelentes profissionais com domínio e conhecimentos técnicos imprescindíveis para a profissão. No entanto o jornalista, na condição de indivíduo que observa e reporta para a sociedade os acontecimentos sociais - a notícia -, deve ter uma boa formação social e política.

Se, por um lado, a leitura crítica da realidade por parte do jornalista é importante, por outro, ele precisa ter o domínio técnico da profissão 
para cumprir a pauta da reportagem, realizar as entrevistas e organizar a informação de forma 'clara e plena', como observa Chaparro (1994).

Também cabe ao jornalista perceber e discutir quando a cobertura que vem sendo dada pela mídia de seu país a determinados assuntos é desrespeitosa com os princípios da cidadania e da ética da comunicação e do jornalismo. Numa análise da realidade em que se desenvolve a prática jornalística, Marcondes Filho (1998: 125) observa que a atividade da imprensa é uma produção de informação diária, contínua e obesa. $O$ ato de informar "torna-se ritualístico e circular" e se perde a própria informação. A imprensa emerge assim, para o autor, como grande canalizador dos anseios sociais, absorvendo importância e prestígio em substituição a instituições que fracassaram, como o Estado.

Muitos teóricos da comunicação e do jornalismo têm revelado preocupações com relação ao tratamento dado pela mídia às questões sociais. A exemplo disso, o XXV Congresso Brasileiros de Ciências da Comunicação, promovido pela Intercom e realizado em Salvador em 2002 com o tema Comunicação para a Cidadania, pautou o compromisso e a responsabilidade social dos meios de comunicação como ponto central do evento.

Mais que isso, entrando no elenco das discussões nacionais, a cidadania deve figurar também na pauta do jornalismo e da formação do jornalista. Uma formação cidadã do jornalista implica numa formação em que valores como os direitos humanos e a democracia sejam permanentemente observados dentro da ética e da responsabilidade social da profissão. Ela constitui, portanto, parte de uma boa formação intelectual que consiga amalgamar esses valores universais com os conteúdos técnicos da profissão.

A esse respeito Chaparro (2005), observando que a formação integral do jornalista dá-se na união do seu aspecto humanístico e técnico, observa: 
(...) o jornalista que a Universidade deverá formar terá de ser um profissional com educadas aptidões de intelectual, capaz de apreender, atribuir significados e dar exposição social confiável (isto é, independente, crítica e honesta) aos conflitos discursivos da atualidade. Mas será intelectualmente inepto se, ao mesmo tempo, não dominar, plena e criativamente, os conceitos, os recursos, as técnicas, as artes e as implicações da linguagem jornalística, ferramentas do seu ofício.

Ao buscar uma definição para o termo intelectual, Antônio Carlos Máximo (2000: 20-21) encontra algumas características comuns em diversos autores que o definem em diferentes momentos históricos. Entre elas, o autor entende que o intelectual é definido pelo "exercício constante da crítica", pela "dedicação ao cultivo das idéias perenes, a vigilância com relação aos valores universalmente válidos da cultura (...), o cultivo das idéias de razão, justiça e democracia" e pela "produção e difusão dos conhecimentos".

É exatamente a essa parte da formação do jornalista - a formação intelectual, que tem base humanística; nas ciências humanas, - a que Maraschin (MARQUES DE MELO; FADUL, 1979) refere-se e que consiste no próprio conceito de formação (em detrimento à 'deformação') apresentado. Ela é, portanto, condição essencial para um exercício ético do jornalismo.

A formação cidadã, que tem raiz no conteúdo humanístico dos cursos de J ornalismo e deve ser conduzida à etapa técnica, corresponde a um desenvolvimento de uma identidade profissional do educando referenciada indissociavelmente num contexto social.

É uma formação em que o indivíduo entende o seu dever e, com a mesma significância, o do outro, de conduzir sua ação (Arendt) em direção à vida, à liberdade, à dignidade e, enfim, aos seus direitos como membro de uma comunidade.

Fazendo questão da redundância, podemos dizer que a formação cidadã é mais que a consciência de estar no mundo: é ter também a consciência de participar dele e, por isso, ter compromissos e responsabilidades com ele e com o outro. 
A formação do jornalista com ênfase nos valores da democracia, dos diretos humanos, da ética e da responsabilidade social da profissão é pré-requisito para um exercício equilibrado e de bom senso da atividade jornalística. Apesar da formação do profissional de jornalismo compreender todo um processo mais amplo de educação ${ }^{17}$, grande parte da responsabilidade cabe à escola, à universidade.

A formação jornalística cidadã é, pois, uma transformação (Maraschin, 1985) tendo por base um conceito de jornalismo sustentado intencionalmente na difusão da notícia 'correta e plena' (Chaparro, 1994) capaz de conduzir o indivíduo que se apropria do material jornalístico a uma ação (Arendt, 1987) baseada no dever de lutar por e preservar seus direitos (Marshall, 1967).

Embora considerando que essa formação ocorra, para efeitos metodológicos, no espaço da 'escola', ela não se dá apenas a partir da proposta e do conteúdo curricular. Numa perspectiva rogeriana, a autenticidade de prática docente pautada no respeito à pessoa e, portanto, na relação que o professor assume com o aluno, tem um papel importante. Segundo Rogers (1973: 265):

A aprendizagem pode ser facilitada, segundo parece, se o professor for "congruente". Isto implica que o professor seja a pessoa que é e que tenha uma consciência plena das atitudes que assume.

O professor é uma pessoa (sic), não a encarnação abstrata de uma exigência curricular ou um canal estéril através do qual o saber passa de geração a geração.

Para o autor, além do compromisso docente, uma relação consciente do discente com o professor, com a sua produção, com a própria escola e com o universo acadêmico, de modo que ele possa investir livremente no seu potencial, também são elementos formadores.

\footnotetext{
${ }^{17}$ Dermeval Saviani (FERRETTI, 1994: 151) considera que enquanto educação refere-se ao constante processo de aprendizado inerente à qualidade humana no dia-a-dia de suas relações sociais, seja na família, na rua ou no trabalho, a escola refere-se a um tipo específico de apreensão do conhecimento; um conhecimento formalizado, organizado. À escola, portanto, caberia uma educação no seu sentido formal; formador.
} 
Arouca (1977) apresenta bem o espírito rogeriano no que diz respeito a essa questão:

(...) os educandos devem ter liberdade para aprender a estabelecer para si mesmos objetivos que estejam dentro de suas possibilidades de realização, concebidos realisticamente, procurando desenvolver seus próprios conceitos. Há em cada pessoa uma consciência que lhe permite não só doar significado aos seus atos, mas também optar livremente por aqueles atos ditados pela consciência.

A vivência, tornando-se cada vez mais aberta, possibilita a cada pessoa ser cada vez mais o arquiteto de si mesmo, para com liberdade escolher os valores de suas convicções mais íntimas.

A autora continua, valorizando uma educação centrada na pessoa; tendo a pessoa humana como centro:

A valorização do homem, tanto objetiva quanto subjetivamente, compreende o uso correto da liberdade para desenvolver suas potencialidades num mundo significativo, onde o progresso de cada um depende de uma educação que permita usar a liberdade criativamente, construindo e desenvolvendo seu próprio processo de contínuo crescimento.

É, portanto, no próprio espaço de formação do jornalista que a cidadania, o sentimento de compromisso com os direitos humanos, a democracia a ética e a responsabilidade social da profissão podem e devem ser reforçados. Como afirma Paulo Freire (1999: 34):

Não há nada que mais contradiga e comprometa a emersão popular do que uma educação que não jogue o educando às experiências do debate e da análise dos problemas e que não Ihe propicie condições de verdadeira participação. 


\subsection{Da Escola de Comunicações e Artes e do Curso de J ornalismo}

Criada a partir de um decreto estadual assinado pelo então governador Armando Salles de Oliveira em janeiro de 1934, a Universidade de São Paulo nasceu com fins políticos convergentes com a Escola de Sociologia e Política. A Escola, surgida em 1933 a partir da iniciativa de alguns líderes da Revolução Constitucionalista de 1932, era "constituída como uma fundação de direito privado, cujos cursos não pretendiam reconhecimento de privilégio ocupacional pelo Estado" (CUNHA: 2000, 167).

De acordo com o Anuário Estatístico ${ }^{18}$ da instituição, a USP ocupa hoje uma área territorial aproximada de $75.300 .000 \mathrm{~m}^{2}$ distribuídos em oito campi no Estado de São Paulo. Sua comunidade é estimada em 95.820 pessoas, sendo 4.953 docentes, 75.962 alunos matriculados (desse total, $44.696(58,8 \%)$ estão na graduação) e 14.905 funcionários técnico-administrativos.

Mais de 30 anos depois da fundação da USP, em 15 de junho de 1966, um decreto assinado pelo então governador Laudo Natel ${ }^{19}$ criou a Escola de Comunicações Culturais, ECC, da Universidade de São Paulo. A partir de 1970 a ECC passou a se chamar Escola de Comunicações e Artes, ECA.

O projeto que criou a ECA como um dos braços da Universidade de São Paulo deu seus primeiros passos um ano antes, em 1965, quando o então reitor Gama e Silva formou uma comissão para estudar a criação de uma Escola de Comunicações na instituição. Dessa comissão participou, entre outros, Júlio Garcia Morejón, que se tornou o primeiro diretor da Escola. Espanhol de nascimento, Morejón havia estudado na

\footnotetext{
${ }^{18}$ USP. Anuário Estatístico 2004.

${ }^{19}$ Natel foi empossado no cargo nove dias antes em substituição a Adhemar Pereira de Barros, cassado pelo Governo Federal, tendo Castelo Branco à frente da Presidência da República.
} 
Faculdade de Filosofia, Ciências e Letras da USP, onde se formou em Filosofia.

As preocupações da comissão eram marcadas por um forte semblante político e por uma necessidade de elaborar e fomentar discussões a respeito das práticas jornalísticas, como estava muito em voga na época. Daí a marca definidora que a criação do Departamento de J ornalismo passou exercer na fundação da escola. Carsten Bruder (2004) observa:

\begin{abstract}
Reformar o curso de jornalismo, encontrar novos caminhos para formar os futuros profissionais era o principal objetivo dessa comissão, que assumiu a sua tarefa no meio de um cenário novo das universidades no mundo inteiro.

A partir da segunda metade dos anos sessenta os movimentos estudantis ganharam força principalmente no Oeste Europeu e nos Estados Unidos. Iniciou-se um debate profundo sobre "valores" e, também, sobre o sistema de educação. Um dos destaques era o ensino superior. Os protestos dos estudantes eram contra a forma do ensino, que foi considerada ultrapassada por eles, e contra o sistema de acesso às principais universidades.
\end{abstract}

O período que vai da segunda metade dos anos 60 até finais dos anos 70 foi um momento de intensa agitação política e estudantil no mundo inteiro, e o Brasil também acompanhou essa tendência. No final dos anos 60, o Departamento de Jornalismo da ECA teve uma ativa participação no processo que discutiu e criou o texto de regulamentação da profissão de jornalista no País.

O professor da ECA José Coelho Sobrinho participou, ainda como estudante da USP, do processo. As atividades, que funcionaram em formato de fórum elaborando moções e textos para fundamentar as discussões, surgiram por iniciativa do professor José Marques de Melo.

De acordo com Coelho (2003), havia duas motivações principais, na ECA, para discutir a regulamentação. Uma delas era de cunho "cartorial", de marcar o espaço de atuação profissional do jornalista e a outra era política e visava a "impedir que a ditadura colocasse nos jornais e nas escolas exatamente quem eles queriam".

Segundo Coelho, a posição política da escola era notadamente de esquerda, com seus vários matizes e nomes conhecidos. O professor 
destaca a atuação dos professores Marques de Melo, Almeida Prado Galvão e Freitas Nobre, que na época já desenvolviam trabalhos em torno da regulamentação profissional do jornalista e cita também a participação de nomes como Suzana Amaral, Etevaldo Siqueira, Walter Sampaio e Wilson da Costa Bueno.

Ao fazer uma análise das contribuições da ECA no texto final da regulamentação da profissão de jornalista em 1969, Coelho observa que houve grande influência das discussões da Escola. Para ele, a regulamentação impediu maiores abusos por parte da ditadura ao impedi-la de formar quadros profissionais na imprensa apenas com nomes indicados por ela.

Para a professora Alice Mitika Koshiyama ([s.d.]), é dos anos 70 até os 80 , especialmente a partir do recrudescimento da ditadura militar no País, que as reflexões sobre a formação do jornalista ecano ganham um caráter mais politizado:

\begin{abstract}
Não por opção de alunos e professores. Mas por imposição das conjunturas históricas: fechamento político, precariedade absoluta de meios para a execução de um trabalho de jornalismo contínuo e periódico, impotência da maioria do corpo docente foram condições que marcaram as atividades de jornalismo na ECA/USP nos anos setenta. A prisão do professor Jair Borin, a descontração dos professores José Marques de Melo, Thomaz Jorge Farkas, José Freitas Nobre do Departamento de Jornalismo e Editoração nos primeiros anos da década, foram apenas sintomas de um processo repressivo político só revertido com a anistia política nos anos 80 .

Constatamos, no entanto, que a organização do movimento estudantil na universidade, em 1975, um dos marcos do processo de abertura política no país, permitiu uma experiência político pedagógica importante para a reflexão sobre ensino do jornalismo.
\end{abstract}

Em 2003, a graduação da ECA contava com 1.848 alunos matriculados ( $4 \%$ do 44.696 estudantes da graduação da USP). No mesmo período, o Departamento de Jornalismo e Editoração contava com um total de 349 alunos matriculados (18,9\% do total da ECA), sendo 264 ( $14,3 \%$ do total da ECA) no curso de Jornalismo (destes, 125 no curso de jornalismo diurno e 139 , do curso noturno $)^{20}$.

\footnotetext{
${ }^{20}$ Esses dados foram obtidos no Anuário Estatístico da Universidade de São Paulo / 2004, até o momento de redação desta dissertação, o último anuário publicado pela instituição.
} 
Além de cursos de pós-graduação Lato e Stricto Sensu, a ECA hoje oferece cursos 11 cursos regulares de graduação distribuídos em 21 habilitações ${ }^{21}$, sendo treze delas voltadas às Artes $e$ oito às Comunicações, distribuídos nos seguintes departamentos ${ }^{22}$ :

1. Departamento de Artes Cênicas (CAC), com uma licenciatura em Educação Artística, habilitação em Artes Cênicas, e bacharelado em Artes Cênicas com habilitações em Cenografia, Direção Teatral, Interpretação Teatral e Teoria do Teatro;

2. Departamento de Artes Plásticas (CAP), com uma licenciatura Educação Artística, habilitação em Artes Plásticas e bacharelados em Escultura, Gravura, Multimídia e Intermídia e Pintura;

3. Departamento de Biblioteconomia e Documentação (CBD), com bacharelado em Biblioteconomia;

4. Departamento de Cinema, Rádio e Televisão (CTR), com bacharelado em Audiovisual;

5. Departamento de Comunicações e Artes (CCA);

6. Departamento de Jornalismo e Editoração (CJE), com bacharelados em J ornalismo e em Editoração;

7. Departamento de Música (CMU), com uma licenciatura em Educação Artística, habilitação em Música e bacharelado em Música com habilitações em Composição, Instrumento, Regência e Canto e Arte Lírica;

8. Vinculado ao CMU funciona também o Departamento de Música de Ribeirão Preto (CMU-RP), com bacharelado em Música;

9. Departamento de Relações Públicas, Propaganda e Turismo (CRP), com bacharelados em Relações Públicas, Publicidade e Propaganda e Turismo.

\footnotetext{
${ }^{21}$ Vinculada à estrutura departamental da ECA funciona também a Escola de Arte Dramática (EAD), com curso técnico profissionalizante na área de Artes.

${ }^{22}$ ECA: USP. Organização departamental. Disponível em: http://www.eca.usp.br/organiza/departam/.
} 
PARTE I I 


\title{
CAPÍTULO IV
}

\section{Do Currículo do Curso de Jornalismo}

\author{
(...) Análise dos fatores que levaram esses veículos \\ a ter em alguns países poder igual, ou até mesmo \\ maior, do que o dos poderes constitucionais. \\ No Brasil, eles ocupam espaços teoricamente \\ reservados à organizações sociais e políticas. Com \\ isso estabelecem importantes relações de poder que \\ necessitam ser analisadas e compreendidas \\ por aqueles que pretendem trabalhar nesses meios \\ ou investigá-los cientificamente.
}

Parte da ementa da disciplina

J ornalismo no Rádio e na TV

As dificuldades de definição e precisão conceitual para currículo são reveladoras dos embates sobre as aspirações e os objetivos da própria Educação e da escola. Ivor F. Goodson (1995: 18) apresenta duas possibilidades que mostram diferentes concepções para o assunto:

1. Currículo como fato:

O 'currículo como fato' precisa ser considerado não como mera ilusão, camada superficial da prática de alunos e professores, mas como uma realidade social, historicamente específica, expressando relações de produção particulares entre pessoas. Semelhante currículo é uma mistificação quando se apresenta como algo que possui vida própria e confunde as relações humanas nas quais, como qualquer conceito de conhecimento, está embutido, fazendo da educação uma coisa que as pessoas não podem compreender nem controlar.

2. Currículo como prática:

Reduz a realidade social de 'curriculum' às intervenções e ações subjetivas de docentes e discentes, impedindo-nos de entender o surgimento e persistência históricos de determinados conceitos, conhecimentos e convenções (como, por exemplo, as matérias 
escolares). Ao sermos impelidos de situarmos historicamente os problemas da educação contemporânea, ficamos também impossibilitados de compreende-los e controlá-los.

A polaridade entre as duas concepções - uma que enxerga o currículo como algo externo ao educando e outra que o percebe como produto da própria dialética educativa ${ }^{23}$ - expõem visões diferentes da Educação.

Para Goodson (1995: 21), no entanto, mais importante do que as definições que possam emanar dos currículos, o que melhor poderia precisá-los são a sua força e o seu funcionamento na sociedade:

O currículo escrito não passa de um testemunho visível, público e sujeito a mudanças, uma lógica que se escolhe para, mediante sua retórica, legitimar uma escolarização. Como tal, o currículo escrito promulga e justifica determinadas intenções básicas de escolarização, à medida que vão sendo operacionalizadas em estruturas e instituições.

Nessa mesma linha, Antônio Flávio B. Moreira (1997) trabalha a questão da concepção curricular sob uma ótica cultural e ideológica. Ele adverte que as condições macro, como o contexto internacional, são importantes para a compreensão dos modelos de currículos adotados no Brasil. No entanto, as teorias da 'transferência educacional' são insuficientes para uma análise segura do quadro.

Para o autor, num nível micro, há pressões e interesses que fazem com que esta influência seja filtrada e muitos de seus aspectos reinterpretados. Moreira (1997: 81) destaca que esse semblante já aparece no início do pensamento curricular brasileiro:

(...) as origens do pensamento curricular podem ser localizadas nos anos vinte e trinta, quando importantes transformações econômicas, sociais, culturais, políticas e ideológicas processaram-se em nosso país. A literatura pedagógica da época refletia as idéias propostas por autores americanos associados ao pragmatismo e às teorias elaboradas por diversos autores europeus. Com base em tais idéias,

\footnotetext{
${ }^{23}$ Para o autor, a dialética educativa refere-se a uma concepção de educação na qual não só o educador decide o que e como ensina. Ao contrário, o projeto é construído na relação entre ele e os educandos.
} 
os pioneiros da Escola Nova ${ }^{24}$ buscaram superar as limitações da antiga tradição jesuítica e da tradição enciclopédica, que teve origem com a influência francesa na educação brasileira, e esforçaram-se por tornar o quase inexistente sistema educacional consistente com o novo contexto.

É exatamente sob esse prisma de influência externa e idiossincrasias regionais que entendemos a implantação e o caminho percorrido pelos currículos dos cursos de Comunicação Social e de Jornalismo - e, de resto, das demais áreas - no Brasil.

Segundo Maria Elisabete Antonioli Laurenti (2002: 01), a trajetória que disciplina os currículos para o curso superior de Jornalismo no âmbito da legislação educacional brasileira compreende três fases.

Uma primeira fase vai de 1946 a 1961. Ela compreende a instituição de um currículo para o curso de Jornalismo e vai até a Lei de Diretrizes e Base da Educação de no. 4.024, de 20 de dezembro de 1961. Esse momento corresponde exatamente ao período de priorização da formação filosófica do jornalista.

O segundo momento estende-se da LDB de 1961 e vai até a promulgação da nova Lei de Diretrizes e Bases da Educação de no . 9.394, de 20 de dezembro 1996. É nessa fase que Jornalismo passa a ser uma habilitação de uma formação mais ampla. Segundo Laurenti (2002: 02):

No decorrer deste período, um paradigma curricular sucedeu no ano de 1969, quando o curso de Jornalismo passou a ser uma habilitação de um novo curso criado pelo Parecer no $631 / 69$ e Resolução no 11, de 6 de agosto, o de Comunicação Social. Além de Jornalismo, outras habilitações foram organizadas: Publicidade e Propaganda, Relações Públicas, Editoração e Polivalente. Essa transformação acarretou várias conseqüências para o antigo curso de Jornalismo ao alterar seu perfil, com a inserção de outras áreas do conhecimento, bem como ao ampliar suas possibilidades profissionais, face às inovações que o mercado apresentava no período.

\footnotetext{
${ }^{24}$ A Escola Nova é uma nova forma de educação introduzida, nos anos 20, no ensino brasileiro. Os saberes e os fazeres escolares passaram a ser adaptados à realidade do educando e a aprendizagem assumiu a soberania do ensino.
} 
A terceira e atual fase começa em 2001 com a instituição das Diretrizes Curriculares para o curso de Comunicação Social. Nessa nova LDB, em seu Capítulo IV (da Educação Superior), Artigo 53 e Parágrafo 2 o , é assegurada às universidades autonomia no gerenciamento de seus currículos. Assim thes cabe "Fixar os currículos dos seus cursos e programas observadas as diretrizes gerais pertinentes".

Retomando o conceito de formação apontado por Maraschin (MARQUES DE MELO; FADUL, 1979), encontramo-nos diante de uma situação peculiar, especialmente num contexto de sociedade de mercado. Neste contexto, a preocupação central da formação profissional têm sido as diretrizes mercadológicas. Gilberto Dupas (2001: 71-72) pondera sobre algumas ambigüidades atuais:

Tecnologias de informação e automação estão hoje presentes em todos os lugares. Compõem as cenas da vida cotidiana, instaladas em nossa intimidade. São filhas do desejo, dele recebendo sua qualidade de ser complexo e não de um simples instrumento. São parceiras ambíguas e desconcertantes, exceto para quem delas tira seus objetivos de lucro e domínio. Operam com autonomia e podem se perverter, tornarem-se nefastas e agredirem o próprio ho mem. A nova sociedade aceita que a técnica se imponha como dotada de um poder próprio, difuso, transnacional, controlado - para o bem e para o mal - pelas grandes empresas mundiais que a construíram e a exploram.

Bucci observa (2002) que

O aluno não é desafiado a ser um cidadão e a proteger a cidadania. Ele é desafiado a ser bem sucedido no mercado e, muitas vezes, não sempre, isto significa estar contra os interesses da cidadania. Esses valores são nocivos para a formação dos grandes jornalistas. Estes são bons não porque perseguiram 0 sucesso, mas porque perseguiram a grandeza do fazer que eles representam.

É neste sentido que uma formação acadêmica sólida e condizente não só com as exigências de mercado, mas, sobretudo, pautada no contexto social precisa ser discutida e implementada pelas escolas e faculdades de Comunicação Social brasileiras. 


\subsection{Da LDB e das Diretrizes Curriculares}

As principais referências que atualmente norteiam a Educação no Brasil estão expressas na Constituição Federal de 1988 e na Lei de Diretrizes e Bases da Educação (LDB) de 1996. Cunha (1991) observa que além dessas referências, as constituições estaduais, promulgadas em 1989, dedicam uma seção especial à educação.

Somado a isso, Cury (Lopes, 2000: 570) chama atenção para o fato de que

Além das constituições nacionais e infranacionais, há ainda um campo pouco trazido à tona. Trata-se das declarações e pactos internacionais assinados pelo Brasil com relação a direitos e garantias de direitos. É o reconhecimento mais alto de um direito, pois, o país que assina o reconhece em sua dimensão internacional. É o caso, por exemplo, do Pacto Internacional dos Direitos Econômicos, Sociais, e Culturais (1996, ONU) ou mesmo a Declaração dos Direitos Humanos da ONU, de 1948. Em muitos casos, a declaração é sobre o direito à educação. Tal é a recente Declaração celebrada em Jomteim (Tailândia) e que gerou o Plano Decenal de Educação para Todos.

Nesse sentido, sobremaneira no que diz respeito ao ensino superior, Afrânio Mendes Catani e João Ferreira de Oliveira (2000: 97) chamam atenção para as interferências e as propostas dos organismos internacionais, especialmente do Banco Mundial, para os países subdesenvolvidos:

O atual perfil da educação superior, as temáticas, as críticas, as tendências e as políticas e estratégias mais significativas, na América Latina, revelam o alto grau de subordinação dos países em relação às orientações dos organismos multilaterais, particularmente do Banco Mundial. As teses centrais do Banco estão amplamente incorporadas, especialmente no que concerne à proposta de maior diversificação e diferenciação dos sistemas, das instituições e das fontes de financiamento, bem com da redefinição das funções do Estado e maior adaptabilidade e receptividade quanto às exigências econômicas, em geral, e do mercado de trabalho, especificamente. 
Para Cury, em todo caso, as Cartas Federais de 1934 e 1988 apresentam grandes avanços na legislação brasileira no que diz respeito à democratização do ensino. Se em 1934 a educação gratuita de primeiro grau passou a ser obrigação do Estado, a Constituição de 1988 considera o ensino um direito público subjetivo ${ }^{25}$ e a sua gratuidade passa a ser constitucionalmente obrigatória nos três diferentes níveis, tanto fundamental quanto médio e superior (nestes dois últimos níveis, quando oferecidos pelos poderes públicos).

Ao mesmo tempo o autor observa que em linhas gerais a LDB de 1996 (conforme já sinalizava a Constituição) passa a atribuir aos municípios, aos estados e à União o compromisso com o ensino fundamental, médio e superior, respectivamente.

Além da legislação, um dos instrumentos de ação do Governo Federal para tentar resguardar a qualidade do ensino superior têm sido os padrões de qualidade. Instrumentos como a nova Lei de Diretrizes e Bases da Educação Superior, as Diretrizes Curriculares de Graduação e o Exame Nacional de Cursos, Provão - que a partir de maio de 2004, no governo de Luís Inácio Lula da Silva, passa a ser chamado Exame Nacional de Desempenho dos Estudantes, Enade - têm gerado polêmica entre docentes, estudantes, setores sindicais e membros do governo.

Se por um lado algumas entidades de professores e estudantes apontam os padrões como ineficazes na fiscalização do ensino, o governo e algumas entidades os defendem como critérios válidos.

\footnotetext{
${ }^{25}$ Nas palavras do autor: “(...) isso significa que o indivíduo que não tiver acesso ao ensino obrigatório doravante possui mecanismos jurídicos postos em sua mão para fazer valer esse direito. Direito público subjetivo é aquele pelo qual o titular de uma prerrogativa pode fazer cumprir um dever cuja efetivação apóia-se em um dispositivo legal que visa à satisfação de um bem indispensável à cidadania" (LOPES, 2000: 575).
} 


\title{
4.2. Do Currículo Ecano
}

A Escola de Comunicações e Artes funcionou, nos seus primeiros anos, com sete cursos profissionalizantes. Além do curso de Jornalismo, havia os cursos de Rádio e TV, Cinema, Relações Públicas, Artes Dramáticas, Biblioteconomia e Documentação.

Assim como ocorria com os demais cursos, o currículo de Jornalismo tinha ênfase na prática profissional e isso refletia, de uma certa maneira, as demandas de mercado em conseqüência de uma crescente industrialização do trabalho da imprensa. Um depoimento do então primeiro diretor da ECA, Júlio Garcia Morejón, nos anos 60, ilustra bem esse quadro (BRUDER: 2004):

\begin{abstract}
Até o presente a maioria das experiências no nosso campo tem sido mais teóricas do que práticas. Talvez a pobreza de recursos tenha nos obrigado a isso. Mas, de agora em diante, à vista do desenvolvimento dos meios de comunicação e, como conseqüência, das responsabilidades que nos cercam, impõe-se, cada vez mais com maior força, um ensino prático da comunicação. Por tal motivo tivemos, ou estamos tendo, o cuidado de dotar a nossa Escola dos veículos próprios para a experimentação.
\end{abstract}

Ao elaborar o primeiro currículo da ECA, Morejón havia inspirado-se em modelos de universidades européias, especialmente espanholas, e nesse sentido o currículo foi considerado um 'protótipo europeu'. Essa ênfase na prática profissional inscreve a ECA, portanto, no que José Salomão Amorim (LAGE, 1985: 08) classificou como segundo momento da formação do jornalismo brasileiro: a formação técnica sobre a formação humanística.

O primeiro currículo ecano encaixa-se também no que Laurenti (2002: 207) identifica como a segunda fase ${ }^{26}$ curricular do ensino superior de Jornalismo no Brasil, quando é instituído o Currículo Mínimo.

\footnotetext{
${ }^{26}$ Segundo Laurenti (2002: 207-208), a primeira fase tem início em 1946 quando são instituídos currículos de "imposição máxima", em que os currículos deveriam ser implantados na íntegra. Na fase seguinte, que tem início em 1962 com a promulgação da Lei de Diretrizes e Bases da Educação Nacional de 1961 é criado
} 
Com uma maior liberdade curricular, além da ênfase profissionalizante o primeiro currículo de Jornalismo ecano considerava também importante a formação histórica, lingüística, estética, filosófica, científica e conhecimentos de ordem política, social, econômica e psicológica.

Criado em fevereiro de 1968, o Departamento de Jornalismo da então Escola de Comunicações Culturais começou a funcionar no mês seguinte e o professor José Marques de Melo, a convite do professor Morejón, foi designado o primeiro coordenador do departamento. Bruder (2004) situa bem o trabalho de Marques de Melo na época:

‘Logo que ele (Morejón) me convida para assumir a direção do departamento e implantar o curso de jornalismo ele me deu inteira liberdade de reformular. Tanto que a minha primeira tarefa foi alterar o currículo do curso', lembra Marques de Melo. Ele considera esta primeira fase na direção do departamento de jornalismo como "abrasileiramento" do curso. Melo destaca, além da reformulação do currículo, um intenso diálogo com as empresas jornalísticas e cita 0 Estado de São Paulo, o J ornal do Brasil e a Editora Abril, entre outras. O resultado deste diálogo refletia diretamente na reformulação do curso de jornalismo.

Em agosto de 1969 foi aprovado um novo currículo para o curso de Jornalismo, marcado por uma divisão mais equilibrada entre a formação humanística e a formação profissional, uma maior flexibilidade para a organização curricular e apontando para a necessidade de implantação de órgãos laboratoriais.

Também a partir daí passou a vigorar o decreto-lei no․ 972 de 12 de outubro de 1969, que exigia diploma de curso superior de Jornalismo registrado no Ministério da Educação e Cultura para o exercício da profissão.

o Currículo Mínimo, que permite alguma liberdade de adaptação curricular às escolas superiores e o currículo "deveria ser complementado por disciplinas escolhidas pela instituição". Por fim, a terceira fase tem início em 1999 e "há liberdade na composição de conteúdos curriculares, pois não existe uma estrutura determinada para o curso, mas sim, parâmetros para a constituição de um currículo, sob a denominação de Diretrizes Curriculares". 
A partir da reabertura política no final dos anos 70, especialmente alguns anos depois, os currículos de Jornalismo passaram a uma nova fase sob influência das novas tecnologias de comunicação.

A partir de uma análise do quadro nacional, Ramadan (2003: 36) chama atenção neste momento da formação do jornalista - que a autora localiza a partir dos anos 90 - para a incorporação das novas tecnologias à formação e ao currículo "sem um amadurecimento pedagógico que relacione nas instâncias prática e teórica as mutações que a profissão vem sofrendo, bem como o ensino de jornalismo".

Elaborado a partir do Currículo Mínimo da Resolução o․ 2 de 1983 e mesclando formação humanística e o aprendizado de habilidades técnicas voltadas para as tecnologias da comunicação e do jornalismo, o atual currículo do curso de Jornalismo noturno ${ }^{27}$ da ECA, em vigor desde 1993, apresenta as seguintes disciplinas obrigatórias organizadas em nove semestres:

\footnotetext{
${ }^{27}$ Nesta pesquisa estudamos o curso de Jornalismo noturno da ECA em detrimento do diurno. Precisamos fazer uma opção já a partir desse momento considerando que os currículos apresentam algumas diferenças.
} 


\section{Primeiro semestre}

\begin{tabular}{|c|c|}
\hline Disciplina & Ementa (Conteúdo) \\
\hline $\begin{array}{l}\text { Lógicas e } \\
\text { Práticas } \\
\text { discursivas } \\
\text { jornalísticas } \\
\text { (CJ E-497) }\end{array}$ & $\begin{array}{l}\text { Lógica: sentidos possíveis, sentidos históricos. A lógica: linguagem e } \\
\text { logos. A lógica da ciência: linguagem científica e jargão. A lógica das } \\
\text { descrições: nomes próprios e símbolos incompletos. A lógica das } \\
\text { proposições: significação e referência. A lógica dos relatos comuns e } \\
\text { a lei da transitividade: a recorrência, a indução e o valor de verdade. } \\
\text { Lógica: o fundamento da crença racional e o fundamento da prova ou } \\
\text { demonstração (dedução). Axiomas lógicos e axiomas extralógicos: os } \\
\text { sistemas dedutivos. Lógica e gramática. Lógica e retórica: } \\
\text { procedimentos de argumentação. A lógica do significante. Tempo } \\
\text { lógico e tempo gramatical. }\end{array}$ \\
\hline $\begin{array}{l}\text { Legislação e } \\
\text { Deontologia } \\
\text { do } \\
\text { Jornalismo } \\
\text { (CJ E-502) }\end{array}$ & $\begin{array}{l}\text { Origem e natureza do Direito como ciência social. Direito e } \\
\text { Legislação. Sistemas jurídicos. Moral e sociedade: a natureza da } \\
\text { norma jurídica. Elementos de teoria geral do Estado. O Direito e os } \\
\text { vários Direitos. Direito Público e Direito Privado. Direito Civil Direito } \\
\text { Penal, do Trabalho etc. O jusnaturalismo e o positivismo. A doutrina } \\
\text { dos direitos de personalidade. Delitos, contravenções, crimes. } \\
\text { Responsabilidade, reparação por dano moral, multas, detenção. A } \\
\text { Constituição Brasileira. O Estado Democrático de Direito. Os direitos } \\
\text { humanos. A proteção dos direitos humanos na ordem brasileira. Leis } \\
\text { especiais. O direito à informação e o direito de comunicar. }\end{array}$ \\
\hline $\begin{array}{l}\text { Fundamentos } \\
\text { Teóricos } \\
\text { da História } \\
\text { (CJE-510) }\end{array}$ & $\begin{array}{l}\text { O historiador e os fatos. História, sociedade e indivíduo. História, } \\
\text { ciência e moral. A causa da História. História e Progresso. A escrita } \\
\text { da História. Temas de pesquisa em História. História e vida cotidiana. }\end{array}$ \\
\hline $\begin{array}{l}\text { Pensamento } \\
\text { Filosófico } \\
\text { (CJ E-518) }\end{array}$ & $\begin{array}{l}\text { Os pré-socráticos e os sofistas: conhecimento e linguagem. A } \\
\text { estrutura e a percepção do mundo segundo Platão e Aristóteles. o } \\
\text { Islã e a Cristandade medieval: a validade do conhecimento. O } \\
\text { recurso do método no racionalismo cartesiano. Matéria, mente e } \\
\text { percepção no empirismo anglo-saxão. A crítica da razão e do juízo } \\
\text { em Kant. O idealismo hegeliano e suas variações materialistas. } \\
\text { Nietzsche: moral e conhecimento. A ontologia existencialista: } \\
\text { conhecimento e liberdade. Intencionalidade e memória. }\end{array}$ \\
\hline $\begin{array}{l}\text { Ciências da } \\
\text { Linguagem: } \\
\text { Fundamentos } \\
\text { das Práticas } \\
\text { Midiáticas I } \\
\text { (CJ E-585) }\end{array}$ & $\begin{array}{l}\text { Ciências Humanas: transformações no domínio das ciências. A } \\
\text { linguagem e a função de comunicação. A linguagem, a língua, a fala, } \\
\text { o discurso. A língua, instituição social: leis do trabalho simbólico. O } \\
\text { signo: concepção saussuriana e concepção peirceana. As práticas da } \\
\text { linguagem: verbal, visual, gestual e escrita. A ordem dos } \\
\text { significados: os objetos do mundo. A anterioridade do significante: o } \\
\text { sujeito. As práticas significantes: o discurso jornalístico. Discurso, } \\
\text { laço social: enunciado e enunciação. Discurso jornalístico: o estatuto } \\
\text { da mediação. Discurso jornalístico: o sujeito e os objetos. As mídias: } \\
\text { a tecnologia e as redes midiáticas. }\end{array}$ \\
\hline $\begin{array}{l}\text { Jornalismo } \\
\text { no Rádio } \\
\text { e na TV } \\
\text { (CJE-600) }\end{array}$ & $\begin{array}{l}\text { O desenvolvimento do rádio e da televisão ao longo do século e as } \\
\text { razões que os tornaram os mais poderosos instrumentos de difusão } \\
\text { de informação em todo o mundo. Análise dos fatores que levaram } \\
\text { esses veículos a ter em alguns países poder igual, ou até mesmo } \\
\text { maior, do que o dos poderes constitucionais. No Brasil, eles ocupam } \\
\text { espaços teoricamente reservados às organizações sociais e políticas, } \\
\text { com isso estabelecem importantes relações de poder que necessitam } \\
\text { ser analisadas e compreendidas por aqueles que pretendem trabalhar } \\
\text { nesses meios ou investigá-los cientificamente. }\end{array}$ \\
\hline
\end{tabular}




\section{Segundo semestre}

\begin{tabular}{|c|c|}
\hline Disciplina & Ementa (Conteúdo) \\
\hline $\begin{array}{l}\text { História } \\
\text { das } \\
\text { Doutrinas } \\
\text { Políticas } \\
\text { (CJ E-517) }\end{array}$ & $\begin{array}{l}\text { Conhecimento, participação e opinião na democracia ateniense. } \\
\text { Maquiavel e o nascimento do pensamento político moderno. As } \\
\text { concepções contratualistas do Direito Natural e a imprensa. Rousseau } \\
\text { e a reconfiguração da opinião pública. Cidadão, governo e sociedade } \\
\text { nas doutrinas liberais. A organização da sociedade segundo o } \\
\text { socialismo pré- marxista. O marxismo: História, alienação e } \\
\text { revolução. O anarquismo e a revolta do cidadão. A social- democracia, } \\
\text { a "nova esquerda" e os direitos do cidadão. Mundialização e } \\
\text { particularismos no final do século XX. }\end{array}$ \\
\hline $\begin{array}{l}\text { Técnicas } \\
\text { Gráficas } \\
\text { em } \\
\text { Jornalismo } \\
\text { (CJ E-522) }\end{array}$ & $\begin{array}{l}\text { Tipologia: estudo dos tipos em famílias e introdução à legibilidade e } \\
\text { visibilidade dos caracteres gráficos. Sistemas de medidas gráficas: } \\
\text { breve histórico e estudo dos principais sistemas. Sistemas gráficos: } \\
\text { características gerais da estereografia, planografia, calcografia e } \\
\text { serigrafia. Sistemas de composição - estudo comparativo dos } \\
\text { processos gráficos de composição. Sistemas de impressão - } \\
\text { características das principais técnicas de impressão e acabamento. } \\
\text { Teoria e prática das cores - seleção e reticulagem. Funções da } \\
\text { diagramação. A infra-estrutura do planejamento gráfico. Cálculo de } \\
\text { textos, títulos e fotografias. Elementos fixos de um periódico.O } \\
\text { aproveitamento do espaço gráfico; centros de referência e linhas de } \\
\text { leitura. As técnicas de cálculo de diagramação. Princípios de } \\
\text { editoração eletrônica - uso dos principais programas. }\end{array}$ \\
\hline $\begin{array}{l}\text { Sociologia } \\
\text { Da } \\
\text { Era Virtual } \\
\text { (CJ E-559) }\end{array}$ & $\begin{array}{l}\text { A ordem lógica: o Caos. Auto- referência e auto- organização. Moderno } \\
\text { e pós- moderno: imagens do desaparecido. A sociedade da era } \\
\text { tecnológica. As classes virtuais. A economia virtual. Corpos } \\
\text { recombinantes. Leitura, saber, informação. Literatura e ficção } \\
\text { cibernética. As utopias do século XIX. Questões ético- morais. }\end{array}$ \\
\hline $\begin{array}{l}\text { Ciências } \\
\text { da } \\
\text { Linguagem: } \\
\text { Fundamentos } \\
\text { das Práticas } \\
\text { Midáticas II } \\
\text { (C) E-586) }\end{array}$ & $\begin{array}{l}\text { A narrativa e as formas de conhecimento: a informação. Narrativas } \\
\text { tradicionais: a crença. O acontecimento: acontecido e desaparecido. } \\
\text { A estrutura discursiva: o real, o simbólico e o imaginário. O } \\
\text { ordenamento narrativo e a ordem imaginária. O real e a realidade: a } \\
\text { construção discursiva. A ordem do simbólico: a enunciação } \\
\text { discursiva. Os quatro discursos contemporâneos e as categorias } \\
\text { fundantes. Discursos imagéticos e discursos verbais: a realidade } \\
\text { televisiva. A questão do poder e o discurso jornalístico: as formas de } \\
\text { legitimação. O discurso jornalístico e a dupla determinação. O } \\
\text { jornalismo e a função testemunhal. }\end{array}$ \\
\hline $\begin{array}{l}\text { Laboratório } \\
\text { de } \\
\text { I niciação ao } \\
\text { J ornalismo } \\
\text { (CJ E-587) }\end{array}$ & $\begin{array}{l}\text { A importância do registro das histórias de vida de pessoas simples } \\
\text { para a composição da história do presente. Notícia: estrutura e } \\
\text { desenvolvimento. Pauta e técnicas de investigação jornalística. A } \\
\text { entrevista como técnica de captação de conteúdos e como estratégia } \\
\text { de diálogo. O jornalismo no universo dos valores: responsabilidade } \\
\text { social e a questão ética. Percepção do olhar e relevância das coisas: } \\
\text { a banalização da violência e do cotidiano. A narrativa da } \\
\text { contemporaneidade. Reportagem: estrutura e desenvolvimento. }\end{array}$ \\
\hline $\begin{array}{l}\text { Ética } \\
\text { (CJ E-615) }\end{array}$ & $\begin{array}{l}\text { Ética: inscrição na linguagem. Distinção: ethos (eqo) e doxa (doxa). } \\
\text { Ética: a instituição discursiva e a validação. Ética: a verdade (alheia). } \\
\text { Ética e o espírito das leis. Ética e profissões: os códigos. Ética da } \\
\text { finalidade. Ética dos efeitos. Ética da responsabilidade: o dever. } \\
\text { Jornalismo: a ética da vigilância. Jornalismo: a ética do engajamento. } \\
\text { Ética: intervenção da tecnociência e da biogenética. Estudos de caso. }\end{array}$ \\
\hline
\end{tabular}




\section{Terceiro semestre}

\begin{tabular}{|c|c|}
\hline Disciplina & Ementa (Conteúdo) \\
\hline $\begin{array}{l}\text { História } \\
\text { do } \\
\text { J ornalismo / } \\
\text { Geral } \\
\text { (CJ E-469) }\end{array}$ & $\begin{array}{l}\text { Jornalismo enquanto produção para o mercado e enquanto militância } \\
\text { política. As condições históricas do surgimento e da formação de um } \\
\text { público leitor do século XVI ao XVIII. Os jornalistas na Revolução } \\
\text { Francesa; as conquistas da burguesia e as sementes da utopia. Os } \\
\text { jornalistas e a defesa dos trabalhadores na Europa do século XIX. Os } \\
\text { jornalistas dos periódicos de massas e a expansão capitalista dos } \\
\text { Estados Unidos nos séculos XIX e XX. Os jornalistas e a defesa da } \\
\text { justiça: o caso Dreyfus. Os jornalistas em luta contra o mundo } \\
\text { capitalista e a Revolução Soviética de 1917. A presença dos } \\
\text { jornalistas nos grandes confrontos militares, políticos e ideológicos } \\
\text { dos anos } 50 \text { aos anos } 80 \text {. Trabalho e a permanência dos controles à } \\
\text { informação. }\end{array}$ \\
\hline $\begin{array}{l}\text { Fundamentos } \\
\text { da Economia } \\
\text { (CJE-506) }\end{array}$ & $\begin{array}{l}\text { Conceitos econômicos fundamentais. Paradoxos da economia. A } \\
\text { atividade econômica nacional. O produto nacional. Moedas e relações } \\
\text { econômicas internacionais. Balanço de pagamentos. Teorias da } \\
\text { dependência e do subdesenvolvimento }\end{array}$ \\
\hline $\begin{array}{l}\text { Teoria } \\
\text { da } \\
\text { Comunicação } \\
\text { (CJ E-508) }\end{array}$ & $\begin{array}{l}\text { Modos de Comunicar: A lingüística estrutural. Os formalistas da } \\
\text { linguagem. A pragmática da comunicação. Agenciamentos coletivos. } \\
\text { Linguagens, tecnologias, mentes: O corpo comunica. Língua e } \\
\text { patologias. Inteligências bastante artificiais. Modos de pensar - Caos, } \\
\text { autopoiesis, catástrofe e auto- organização. Lógicas, ambigüidades e } \\
\text { paradoxos. Modos de saber: Teóricos críticos. A angústia das massas } \\
\text { Teoria matemática da comunicação. Do positivismo ao behaviorismo. } \\
\text { Comunicação e extensão do homem. Estruturalismos. As novas } \\
\text { tendências. }\end{array}$ \\
\hline $\begin{array}{l}\text { Conceitos } \\
\text { e Gêneros do } \\
\text { J ornalismo } \\
\text { (CJ E-563) }\end{array}$ & $\begin{array}{l}\text { Jornalismo e suas relações com a atualidade. Jornalismo como } \\
\text { ambiente de conflitos. Jornalismo como linguagem interdiscursiva. } \\
\text { Estratégias da ação jornalística. Entendimento pragmático da ação } \\
\text { jornalística. Gêneros: revisão crítica de conceitos e bibliografia. } \\
\text { Gêneros: revisão crítica do paradigma anglo- saxônico. Gêneros, } \\
\text { formas do discurso. Espécies do relato J ornalístico (Sistema } \\
\text { Narrativo). Espécies do Comentário J ornalístico (Sistema } \\
\text { Argumentativo). Conclusões. }\end{array}$ \\
\hline
\end{tabular}




\section{Quarto semestre}

\begin{tabular}{|c|c|}
\hline Disciplina & Ementa (Conteúdo) \\
\hline $\begin{array}{l}\text { Geren- } \\
\text { ciamento } \\
\text { de empresas } \\
\text { jornalísticas } \\
\text { (CJ E-432) }\end{array}$ & $\begin{array}{l}\text { Conceito de "produto informativo": características e componentes. } \\
\text { Complexidade e funções paralelas. Ciclo de vida. Os planos das } \\
\text { empresas jornalísticas brasileiras: uma combinação entre atividades } \\
\text { gerenciais e editoriais. Estratégias de negócios, planos de negócios; } \\
\text { Estratégia digital. Competitividade e cadeia de valor. Estrutura } \\
\text { organizacional, estrutura nas redações, redação on line e redação } \\
\text { tradicional. A variável tecnologia nas empresas informativas: } \\
\text { inovações, ferramentas de apoio à edição/reportagem. As } \\
\text { competências de uma redação. Programas de qualidade nas } \\
\text { redações. Área comercial de jornais. Habilidades/capacitações do } \\
\text { jornalista: comparação entre a prática de mercado e a realidade } \\
\text { acadêmica. }\end{array}$ \\
\hline $\begin{array}{l}\text { História } \\
\text { do } \\
\text { Jornalismo / } \\
\text { Brasil } \\
\text { (CJ E-442) }\end{array}$ & $\begin{array}{l}\text { J ornalismo e desenvolvimento capitalista no Brasil. História do } \\
\text { Jornalismo no Brasil: periodização, temas e personagens. Os } \\
\text { jornalistas e a censura à informação. Os jornalistas do século XIX: da } \\
\text { Independência à República. Os jornalistas dos anos } 30 \text { e } 40: \text { política, } \\
\text { censura e liberdade. Os jornalistas da República Velha e a defesa dos } \\
\text { interesses das elites e dos trabalhadores. Os jornalistas dos anos } 50 \\
\text { aos anos } 60: \text { a constituição de um mercado de trabalho e a ação } \\
\text { política e social. Os jornalistas e o movimento de } 64: \text { as opções } \\
\text { ideológicas da categoria. Os jornalistas de } 68 \text { aos anos } 80: \text { as } \\
\text { censuras e as resistências ao arbítrio. A formação do jornalista no } \\
\text { Brasil: das redações e associações às escolas e aos sindicatos. }\end{array}$ \\
\hline $\begin{array}{l}\text { Elementos de } \\
\text { Foto- } \\
\text { jornalismo } \\
\text { (CJ E-589) }\end{array}$ & $\begin{array}{l}\text { História ocidental. História da fotografia. A câmara escura. A câmara } \\
\text { fotográfica. Técnica e saída fotográfica em cor. Elementos de } \\
\text { fotojornalismo. Direito autoral do fotógrafo. História do } \\
\text { fotojornalismo. A fotografia de rua. Elementos de linguagem } \\
\text { fotográfica. Concepção e realização de foto-reportagem. Análise e } \\
\text { edição de imagens. }\end{array}$ \\
\hline $\begin{array}{l}\text { Laboratório } \\
\text { de } \\
\text { Jornalismo } \\
\text { I mpresso I } \\
\text { (CJE-590) }\end{array}$ & $\begin{array}{l}\text { Edição semanal de um boletim noticioso. Pauta: importância, } \\
\text { vantagens e desvantagens, o pauteiro. Apuração de dados: técnicas } \\
\text { de coleta de dados, especialmente entrevista; a importância das } \\
\text { fontes, o setorismo. Estrutura da notícia: Conceito e características } \\
\text { da notícia; formas de redação; pirâmide invertida, pirâmide normal, } \\
\text { pirâmide mista; o lead, seus diversos tipos e sua redação; dicas } \\
\text { básicas de estruturação do texto; redação de texto informativo } \\
\text { comum ou mais fontes; análise do texto. Título: tipos de títulos, } \\
\text { macetes que facilitam sua elaboraçãa; a estrutura do título; } \\
\text { palavras- chave; a importância do título; títulos padronizados. Edição: } \\
\text { a função do editor; ruídos e interferências na edição; a intenção na } \\
\text { edição; a hierarquização das matérias em uma página de jornal. } \\
\text { Outros gêneros de texto jornalístico: interpretação e opinião. Manual } \\
\text { de redação: sua importância dentro da política editorial do jornal. }\end{array}$ \\
\hline
\end{tabular}




\section{Quinto semestre}

\begin{tabular}{|l|l|}
\hline Disciplina & Ementa (Conteúdo) \\
\hline Laboratório & Edição quinzenal do J ornal do Campus: Elaboração de pautas. Prática \\
de & de gêneros jornalísticos. Edição de J ornal. Controle de edição e \\
Jornalismo & distribuição. Discussão de política editorial e controle de qualidade. \\
I mpresso II & Diagramação: O projeto gráfico: personalidade e racionalidade. As \\
(CJE-602) & malhas do espaço gráfico. As técnicas de pré- diagramação. \\
& Comunicação e programação visual no jornal. A execução \\
& informatizada do diagrama. Edição J ornalística. Conceitos \\
& jornalísticos de edição. Edição para comunicação de massa. O \\
& instrumental da edição. Fechamento editorial do jornal diário. \\
& Avaliação do trabalho de edição. \\
\hline
\end{tabular}

\section{Sexto semestre}

\begin{tabular}{|c|c|}
\hline Disciplina & Ementa (Conteúdo) \\
\hline $\begin{array}{l}\text { Laboratório } \\
\text { de } \\
\text { Jornalismo } \\
\text { I mpresso I I I } \\
\text { (CJ E-524) }\end{array}$ & $\begin{array}{l}\text { Aulas teóricas e práticas envolvendo reflexões sobre o fazer } \\
\text { jornalístico, pautas, redação e edição de Jornal. Prática jornalística: } \\
\text { Reflexões sobre prática nas redações, reportagens e pautas. } \\
\text { Entrevistas. Noticiário Geral fait divers. Artigos assinados. Pesquisas } \\
\text { com a finalidade de produzir matérias para o J ornal Laboratório. } \\
\text { Edições Fotografia Jornalística. Diagramação. Arte final. Avaliações } \\
\text { do fazer: Análise da edição. Avaliação do desempenho nas tarefas. } \\
\text { Propostas. Crítica interna e externa. }\end{array}$ \\
\hline $\begin{array}{l}\text { Tele- } \\
\text { jornalismo } \\
\text { (CJ E-526) }\end{array}$ & $\begin{array}{l}\text { Os alunos já dominam as duas principais etapas da produção de } \\
\text { notícias: a reportagem e a edição. Estão, portanto, em condições de } \\
\text { passarem à montagem de telejornais. A matéria passa a ser vista, } \\
\text { em seu peso específico, dentro do contexto geral de todas as notícias } \\
\text { que compõem a edição daquele dia. É o momento de se aprofundar } \\
\text { na discussão do espelho e na preparação do estúdio para a gravação: } \\
\text { discute-se o uso do teleprompter, da mesa de corte, das câmeras de } \\
\text { estúdio, a importância do cenário e da iluminação correta, as } \\
\text { questões estéticas, de linguagem e de dicção envolvidas na } \\
\text { participação do apresentador e gravam se telejornais; quanto mais } \\
\text { melhor. Esse semestre tem um valor bastante específico: é prático no } \\
\text { sentido de que as atividades só se realizam se os alunos se } \\
\text { envolverem diretamente em todas as etapas da produção, mas deve- } \\
\text { se retomar discussões de natureza teórica que estão por trás desse } \\
\text { processo. De posse dos conceitos e informações já obtidos nesse } \\
\text { estágio, os alunos estarão melhor aparelhados para retomar a análise } \\
\text { do telejornalismo praticado no país - daí a necessidade e o momento } \\
\text { oportuno - de se fazer análises comparativas dos principais } \\
\text { telejornais tanto do ponto de vista do conteúdo, quanto da forma. }\end{array}$ \\
\hline $\begin{array}{l}\text { Radio- } \\
\text { jornalismo } \\
\text { (CJ E-603) }\end{array}$ & $\begin{array}{l}\text { Evolução do jornalismo no rádio: conceitos e avaliação crítica. O } \\
\text { conteúdo programático no rádio e o jornalismo. As manifestações } \\
\text { jornalísticas no rádio. A linguagem oral e a linguagem radiofônica. A } \\
\text { notícia em rádio: da fonte à transmissão. Regras de redação da } \\
\text { notícia. A reportagem: captação e realização. Apresentação de } \\
\text { programas jornalísticos. Expressão da opinião em rádio: entrevistas e } \\
\text { debates. Prática. }\end{array}$ \\
\hline
\end{tabular}


Sétimo semestre

\begin{tabular}{|c|c|}
\hline Disciplina & Ementa (Conteúdo) \\
\hline $\begin{array}{l}\text { Projetos } \\
\text { Em } \\
\text { Televisão } \\
\text { (CJ E-533) }\end{array}$ & $\begin{array}{l}\text { Os alunos terão a possibilidade de desenvolver projetos específicos } \\
\text { que estejam de acordo com preferências pessoais. A liberdade de } \\
\text { criação é ampla: os alunos podem, por exemplo, montar um projeto } \\
\text { de um novo tipo de programa esportivo. Outro grupo pode se dedicar } \\
\text { à formatação de um projeto jornalístico voltado para a área cultural. } \\
\text { Um terceiro grupo pode se interessar em montar um programa de } \\
\text { debates políticos e assim por diante.Espera-se que nessa etapa os } \\
\text { alunos possam se envolver em projetos fora da ECA. O melhor } \\
\text { exemplo seria a participação junto às equipes do Rádio e Tevê que } \\
\text { estão produzindo material para o Canal Universitário. }\end{array}$ \\
\hline $\begin{array}{l}\text { Projetos } \\
\text { Em } \\
\text { Rádio } \\
\text { (CJ E-532) }\end{array}$ & $\begin{array}{l}\text { Programas jornalísticos: da pauta à realização. Estratégias de } \\
\text { produção. Reportagem. Transmissão "ao vivo". A entrevista. Edição } \\
\text { de matérias jornalísticas. Formatos jornalísticos. Programas } \\
\text { especiais. Apresentação de programas. Interação ouvinte/emissora. }\end{array}$ \\
\hline $\begin{array}{l}\text { Jornalismo } \\
\text { on line - } \\
\text { Paradigmas } \\
\text { e conteúdos } \\
\text { (CJ E-599) }\end{array}$ & $\begin{array}{l}\text { As diferenças e as aproximações entre o "mundo on line" e o "mundo } \\
\text { real". Fluxos de processamento da notícia (linear versus contínuo). } \\
\text { Hipermídia: conceitos e técnicas. A tridimensionalidade da } \\
\text { informação on line (captação, edição, arquivamento). Estrutura de } \\
\text { redação on line: novas funções-convivência com as redações } \\
\text { tradicionais. Uso de ferramentas digitais: e- mail, foto e vídeo digitais, } \\
\text { base de dados remota, bookmarks, infografia, animação. } \\
\text { Procedimentos editoriais no jornalismo on line. Normas legais e ética } \\
\text { no jornalismo on line. Algumas teorias sobre "empacotamento" da } \\
\text { informação. O papel do consumidor enquanto produtor e editor de } \\
\text { conteúdos. }\end{array}$ \\
\hline
\end{tabular}




\section{Oitavo semestre}

\begin{tabular}{|c|c|}
\hline Disciplina & Ementa (Conteúdo) \\
\hline $\begin{array}{l}\text { Espe- } \\
\text { cialização } \\
\text { em } \\
\text { J ornalismo: } \\
\text { Livro- } \\
\text { reportagem } \\
\text { (CJ E-597) }\end{array}$ & $\begin{array}{l}\text { O livro-reportagem no contexto da produção jornalística } \\
\text { contemporânea: sua especificidade, função e relevância. Breve } \\
\text { histórico: sua trajetória na Europa anglo-saxã, nos Estados Unidos, } \\
\text { no Brasil e em exemplos pontuais de outros países latino- } \\
\text { americanos. A interface com a tradição do jornalismo literário. O } \\
\text { espírito renovador do new journalism norte-americano. Legado } \\
\text { histórico brasileiro: as experiências dinamizadoras da revista } \\
\text { Realidade e do J ornal da Tarde. Espaço de incentivo: a contribuição } \\
\text { da ECA através da série "São Paulo de Perfil". A arte de amplificar o } \\
\text { presente: do jornalismo convencional ao jornalismo aberto ao } \\
\text { pensamento complexo. Instrumentos de sensibilização do narrador: a } \\
\text { Escrita Total, a visualização criativa e a observação participante. } \\
\text { Instrumentos de apoio operacional: a pesquisa de antecedentes, o } \\
\text { planejamento sistêmico de pautas e os mapas mentais. Instrumentos } \\
\text { sofisticados: as histórias de vida e a jornada do herói. Desafios } \\
\text { futuros: a transdisciplinaridade na narrativa jornalística. Desafios } \\
\text { futuros: o jornalismo e a co-criação da realidade. Projeto de } \\
\text { Trabalho: Leituras artísticas e leitura cultural no jornalismo. Leituras } \\
\text { reflexivas: bibliografia especializada. }\end{array}$ \\
\hline $\begin{array}{l}\text { Laboratório } \\
\text { em } \\
\text { Jornalismo } \\
\text { I mpresso - } \\
\text { Revista } \\
\text { (CJE-601) }\end{array}$ & $\begin{array}{l}\text { Reflexões teóricas sobre as especificidades sócio-político-culturais do } \\
\text { meio "revista". Ensino, debate e prática de conceitos e técnicas de } \\
\text { pauta, investigação jornalística, texto jornalístico (narração e } \\
\text { argumentação) e design. Pesquisa e experimentação de linguagens } \\
\text { de vanguarda para a comunicação jornalística impressa. }\end{array}$ \\
\hline $\begin{array}{l}\text { Docu- } \\
\text { mentários } \\
\text { em Vídeo } \\
\text { (CJE-604) }\end{array}$ & $\begin{array}{l}\text { O que é o documentário. Breve história do documentário no cinema, } \\
\text { na TV e no Vídeo. O Vídeo nas empresas. I magem e ideologia: o } \\
\text { "olhar do diretor". Os modos de representação no documentário. } \\
\text { Elementos de linguagem do documentário. Os diferentes tipos de } \\
\text { documentários. Metodologia para elaboração de roteiro para } \\
\text { documentário e vídeo institucional. Gravação e edição de programas. } \\
\text { As novas tecnologias digitais e o futuro do documentário e do vídeo } \\
\text { institucional. }\end{array}$ \\
\hline
\end{tabular}

Nono semestre

\begin{tabular}{|l|l|}
\hline Disciplina & Ementa (Conteúdo) \\
\hline Projeto & Pesquisas e/ou elaboração de projetos nas seguintes áreas de \\
Experimental & pesquisa: Processos Jornalísticos. Jornalismo I mpresso. Jornalismo \\
em & Eletrônico. Jornalismo Comparado. J ornalismo e Linguagem. \\
Jornalismo & Jornalismo e Cidadania. Jornalismo, Mercado e Tecnologia. \\
(CJE-411) & Jornalismo e Epistemologia. \\
\hline
\end{tabular}

\footnotetext{
${ }^{28}$ Os projetos experimentais, também conhecidos como trabalhos de conclusão de curso (TCCs), produzidos pelos alunos do curso de J ornalismo noturno da ECA nos anos 2002 e 2003 constituem uma parte específica da pesquisa. Ver capítulo VII.
} 
Somadas a essas, aparecem as seguintes disciplinas optativas:

Semestres ímpares: CJ E0499 História da Ciência, CJ E0523 Jornalismo Comparado, CJE0556 Leitura e Produção de Textos, CJE0605 Crítica de Teatro na Imprensa e Dialogismo, CJE0606 Design Gráfico, CJE0613 Estudo de Caso - Imprensa Semanal, FLG0606 Geografia Humana, Geral e do Brasil, CJE0395 Cultura e Literatura Brasileira I, CJE0519 Jornalismo Brasileiro, CJE0551 J ornalismo Científico, CJE0561 Edição de Texto em Revistas, CJE0575 Jornalismo e Saúde: A Experiência Brasileira, CJE0594 Logos e Tekhnè: Determinantes da Tecnologia Sobre as Práticas Midiáticas, CJE0616 Jornalismo das Grandes Reportagens, CJE0249 História da Editoração, CJE0330 Legislação e Ética da Indústria Editorial, CJE0382 Comunicação Visual e Técnicas de Documentação na Indústria Editorial, CJE0482 Política Internacional e J ornalismo e CJE0576 Jornalismo em Agrobusiness e Meio Ambiente no Brasil.

Semestres pares: CJE0541 Jornalismo, Saúde e Cidadania, CJE0564 Edição de Imagem em Revistas, CJE0580 História da Cultura e da Escrita, CJE0384 Edição de Livros Populares, CJE0595 Discursos Jornalísticos e Estigmas Sociais, CJE0598 Introdução às Tecnologias de Informação On Line, CJ E0617 Introdução à Pesquisa Científica, CJ E0618 Estudo de Caso - o Radiojornalismo, CJE0247 Fundamentos da Editoração, CJE0381 Indústria Editorial e Planejamento em Comunicação, CJE0384 Edição de Livros Populares, CJE0396 Cultura e Literatura Brasileira II, CJ E0539 Editoração em História em Quadrinhos, CJE0579 Laboratório de Jornalismo Digital: Publicações na Internet, CJE0582 História da Comunicação e da Opinião Pública, CJE0434 Jornalismo Sindical, CJE0489 J ornalismo Econômico, CJE0550 Pesquisa em Jornalismo, CJE0583 História e Estética da Fotografia, CJE0610 Cultura e Literatura Brasileira III e CJE0614 Estudo de Caso - Imprensa Diária. 


\subsection{Da Apresentação e da Análise dos Dados da Pesquisa}

A primeira fase da presente pesquisa corresponde a uma análise do atual currículo do curso de Jornalismo noturno da ECA (em vigor desde 1993, com algumas modificações como inclusão e exclusão de disciplinas).

Neste ponto, nos colocamos diante da seguinte questão: se o currículo tem sido o alicerce da formação acadêmica do jornalista e, por outro lado, ao considerarmos a cidadania o elemento que melhor define a prática da atividade jornalística, em que momentos ela aparece na formação desse profissional no atual currículo do curso de Jornalismo noturno da ECA?

A partir desse ponto, partimos para a análise das disciplinas obrigatórias que apresentam, em algumas de suas ementas, conteúdos pertinentes ao conceito que propomos para a cidadania. Nesse sentido, destacamos conteúdos relacionados aos direitos humanos, à democracia, à ética profissional e à responsabilidade social do jornalismo.

Constatamos que as disciplinas obrigatórias que apresentam em suas ementas esses conteúdos concentram-se do primeiro ao quarto semestre. Esta triagem apontou que do total das 31 (trinta e uma) disciplinas obrigatórias, 11 (onze) apresentam conteúdos afins com o que nos propomos a estudar.

No quadro abaixo, em seguida ao nome e à ementa de cada disciplina, registramos mais claramente as nossas observações: 


\begin{tabular}{|c|c|c|}
\hline Disciplina & Ementa (Conteúdo) & $\begin{array}{l}\text { Relação com a } \\
\text { cidadania }\end{array}$ \\
\hline $\begin{array}{l}\text { Legislação e } \\
\text { Deontologia } \\
\text { do } \\
\text { J ornalismo } \\
\text { (CJ E-502) }\end{array}$ & $\begin{array}{l}\text { Origem e natureza do Direito como ciência } \\
\text { social. Direito e Legislação. Sistemas } \\
\text { jurídicos. Moral e sociedade: a natureza da } \\
\text { norma jurídica. Elementos de teoria geral } \\
\text { do Estado. O Direito e os vários Direitos. } \\
\text { Direito Público e Direito Privado. Direito } \\
\text { Civil, Direito Penal, do Trabalho etc. O } \\
\text { jusnaturalismo e o positivismo. A doutrina } \\
\text { dos direitos de personalidade. Delitos, } \\
\text { contravenções, crimes. Responsabilidade, } \\
\text { reparação por dano moral, multas, } \\
\text { detenção. A Constituição Brasileira. O } \\
\text { Estado Democrático de Direito. Os direitos } \\
\text { humanos. A proteção dos direitos } \\
\text { humanos na ordem brasileira. Leis } \\
\text { especiais. O direito à informação e o } \\
\text { direito de comunicar. }\end{array}$ & $\begin{array}{l}\text { Forte apelo aos valores } \\
\text { da cidadania ao discutir } \\
\text { questões relacionadas ao } \\
\text { Direito, à Moral e ao } \\
\text { Estado. Agregue-se a } \\
\text { isso temas relacionados } \\
\text { à Constituição Brasileira. }\end{array}$ \\
\hline $\begin{array}{l}\text { Fundamentos } \\
\text { Teóricos da } \\
\text { História } \\
\text { (CJE-510) }\end{array}$ & $\begin{array}{l}\text { O historiador e os fatos. História, } \\
\text { sociedade e indivíduo. História, ciência e } \\
\text { moral. A causa da História. História e } \\
\text { Progresso. A escrita da História. Temas de } \\
\text { pesquisa em História. História e vida } \\
\text { cotidiana. }\end{array}$ & $\begin{array}{l}\text { Entender a dinâmica da } \\
\text { história é fundamental } \\
\text { para uma formação } \\
\text { cidadã que não pode } \\
\text { perder de vista as } \\
\text { idiossincrasias do sujeito } \\
\text { histórico e seu papel na } \\
\text { consolidação de valores } \\
\text { e modelo de mundo. }\end{array}$ \\
\hline $\begin{array}{l}\text { Pensamento } \\
\text { Filosófico } \\
\text { (CJE-518) }\end{array}$ & $\begin{array}{l}\text { Os pré-socráticos e os sofistas: } \\
\text { conhecimento e linguagem. A estrutura e a } \\
\text { percepção do mundo segundo Platão e } \\
\text { Aristóteles. O I slã e a Cristandade } \\
\text { medieval: a validade do conhecimento. O } \\
\text { recurso do método no racionalismo } \\
\text { cartesiano. Matéria, mente e percepção no } \\
\text { empirismo anglo-saxão. A crítica da razão } \\
\text { e do juízo em Kant. O idealismo hegeliano } \\
\text { e suas variações materialistas. Nietzsche: } \\
\text { moral e conhecimento. A ontologia } \\
\text { existencialista: conhecimento e liberdade. } \\
\text { Intencionalidade e memória. }\end{array}$ & $\begin{array}{l}\text { Na medida em que } \\
\text { representa uma tentativa } \\
\text { de discussão coerente do } \\
\text { mundo, a Filosofia é uma } \\
\text { das bases para qualquer } \\
\text { postura crítica que se } \\
\text { pretenda ter em relação } \\
\text { a concepções de valores } \\
\text { e sociedade, inclusive } \\
\text { das visões que apontam } \\
\text { a cidadania como um } \\
\text { elemento de relevo. }\end{array}$ \\
\hline
\end{tabular}




\begin{tabular}{|c|c|c|}
\hline $\begin{array}{l}\text { Jornalismo } \\
\text { no Rádio e } \\
\text { na TV } \\
\text { (CJ E-600) }\end{array}$ & $\begin{array}{l}\text { O desenvolvimento do rádio e da televisão } \\
\text { ao longo do século e as razões que os } \\
\text { tornaram os mais poderosos instrumentos } \\
\text { de difusão de informação em todo o } \\
\text { mundo. Análise dos fatores que levaram } \\
\text { esses veículos a ter em alguns países } \\
\text { poder igual, ou até mesmo maior, do que } \\
\text { o dos poderes constitucionais. No Brasil, } \\
\text { eles ocupam espaços teoricamente } \\
\text { reservados às organizações sociais e } \\
\text { políticas, com isso estabelecem } \\
\text { importantes relações de poder que } \\
\text { necessitam ser analisadas e } \\
\text { compreendidas por aqueles que } \\
\text { pretendem trabalhar nesses meios ou } \\
\text { investigá- los cientificamente. }\end{array}$ & $\begin{array}{l}\text { Discutir o alcance do } \\
\text { rádio e da TV no mundo, } \\
\text { especialmente no Brasil, } \\
\text { é importante para } \\
\text { compreender o papel da } \\
\text { comunicação como } \\
\text { elemento fomentador, ou } \\
\text { não, da cidadania, mas, } \\
\text { em todo caso, } \\
\text { socializador. }\end{array}$ \\
\hline $\begin{array}{l}\text { História das } \\
\text { Doutrinas } \\
\text { Políticas } \\
\text { (CJ E-517) }\end{array}$ & $\begin{array}{l}\text { Conhecimento, participação e opinião na } \\
\text { democracia ateniense. Maquiavel e o } \\
\text { nascimento do pensamento político } \\
\text { moderno. As concepções contratualistas } \\
\text { do Direito Natural e a imprensa. Rousseau } \\
\text { e a reconfiguração da opinião pública. } \\
\text { Cidadão, governo e sociedade nas } \\
\text { doutrinas liberais. A organização da } \\
\text { sociedade segundo o socialismo pré- } \\
\text { marxista. O marxismo: História, alienação } \\
\text { e revolução. O anarquismo e a revolta do } \\
\text { cidadão. A social- democracia, a "nova } \\
\text { esquerda" e os direitos do cidadão. } \\
\text { Mundialização e particularismos no final do } \\
\text { século XX. }\end{array}$ & $\begin{array}{l}\text { A cidadania e os direitos } \\
\text { humanos são a tônica de } \\
\text { qualquer discussão que } \\
\text { se faça em torno de } \\
\text { doutrinas políticas. O } \\
\text { cidadão é tema } \\
\text { recorrente em autores } \\
\text { como Rousseau e Marx, } \\
\text { que servem de base para } \\
\text { as reflexões sobre a } \\
\text { cidadania } \\
\text { contemporânea em } \\
\text { autores como Arendt e } \\
\text { Pinsky. }\end{array}$ \\
\hline $\begin{array}{l}\text { Sociologia da } \\
\text { Era Virtual } \\
\text { (CJE-559) }\end{array}$ & $\begin{array}{l}\text { A ordem lógica: o Caos. Auto-referência e } \\
\text { auto- organização. Moderno e pós- } \\
\text { moderno: imagens do desaparecido. A } \\
\text { sociedade da era tecnológica. As classes } \\
\text { virtuais. A economia virtual. Corpos } \\
\text { recombinantes. Leitura, saber, informação. } \\
\text { Literatura e ficção cibernética. As utopias } \\
\text { do século XIX. Questões ético- morais. }\end{array}$ & $\begin{array}{l}\text { A discussão dos } \\
\text { conceitos e dos } \\
\text { princípios que regem as } \\
\text { novas tecnologias é de } \\
\text { grande valor na } \\
\text { formação do jornalista } \\
\text { que se prepara para } \\
\text { atuar numa sociedade } \\
\text { cada vez mais } \\
\text { contraditória e } \\
\text { excludente, inclusive no } \\
\text { que diz respeito aos } \\
\text { espaços virtuais. }\end{array}$ \\
\hline
\end{tabular}




\begin{tabular}{|c|c|c|}
\hline $\begin{array}{l}\text { Laboratório } \\
\text { de I niciação } \\
\text { ao } \\
\text { J ornalismo } \\
\text { (CJ E-587) }\end{array}$ & $\begin{array}{l}\text { A importância do registro das histórias de } \\
\text { vida de pessoas simples para a } \\
\text { composição da história do presente. } \\
\text { Notícia: estrutura e desenvolvimento. } \\
\text { Pauta e técnicas de investigação } \\
\text { jornalística. A entrevista como técnica de } \\
\text { captação de conteúdos e como estratégia } \\
\text { de diálogo. O jornalismo no universo dos } \\
\text { valores: responsabilidade social e a } \\
\text { questão ética. Percepção do olhar e } \\
\text { relevância das coisas: a banalização da } \\
\text { violência e do cotidiano. A narrativa da } \\
\text { contemporaneidade. Reportagem - } \\
\text { estrutura e desenvolvimento. }\end{array}$ & $\begin{array}{l}\text { O jornalismo aparece } \\
\text { aqui não só como uma } \\
\text { técnica, mas também } \\
\text { como uma prática } \\
\text { condicionada por um } \\
\text { forte teor ético e moral. } \\
\text { A disciplina oferece uma } \\
\text { perspectiva em que a } \\
\text { Ética e a técnica andam } \\
\text { juntas. }\end{array}$ \\
\hline $\begin{array}{l}\text { Ética } \\
\text { (CJ E-615) }\end{array}$ & $\begin{array}{l}\text { Ética: inscrição na linguagem. Distinção: } \\
\text { ethos (eqo) e doxa (doxa). Ética: a } \\
\text { instituição discursiva e a validação. Ética: } \\
\text { a verdade (alheia). Ética e o espírito das } \\
\text { leis. Ética e profissões: os códigos. Ética } \\
\text { da finalidade. Ética dos efeitos. Ética da } \\
\text { responsabilidade: o dever. Jornalismo: a } \\
\text { ética da vigilância. Jornalismo: a ética do } \\
\text { engajamento. Ética: intervenção da } \\
\text { tecnociência e da biogenética. Estudos de } \\
\text { caso. }\end{array}$ & $\begin{array}{l}\text { As discussões éticas } \\
\text { alcançam um ponto } \\
\text { máximo nesta etapa do } \\
\text { curso. Compreender as } \\
\text { diferentes facetas e } \\
\text { alcance da prática } \\
\text { profissional do jornalista } \\
\text { é fundamento para uma } \\
\text { prática cidadã. }\end{array}$ \\
\hline $\begin{array}{l}\text { História do } \\
\text { Jornalismo / } \\
\text { Geral } \\
\text { (CJ E-469) }\end{array}$ & $\begin{array}{l}\text { Jornalismo enquanto produção para o } \\
\text { mercado e enquanto militância política. As } \\
\text { condições históricas do surgimento e da } \\
\text { formação de um público leitor do século } \\
\text { XVI ao XVIII. Os jornalistas na Revolução } \\
\text { Francesa; as conquistas da burguesia e as } \\
\text { sementes da utopia. Os jornalistas e a } \\
\text { defesa dos trabalhadores na Europa do } \\
\text { século XIX. Os jornalistas dos periódicos } \\
\text { de massas e a expansão capitalista dos } \\
\text { Estados Unidos nos séculos XIX e XX. Os } \\
\text { jornalistas e a defesa da justiça: o caso } \\
\text { Dreyfus. Os jornalistas em luta contra o } \\
\text { mundo capitalista e a Revolução Soviética } \\
\text { de } 1917 \text {. A presença dos jornalistas nos } \\
\text { grandes confrontos militares, políticos e } \\
\text { ideológicos dos anos } 50 \text { aos anos } 80 \text {. } \\
\text { Trabalho e a permanência dos controles à } \\
\text { informação. }\end{array}$ & $\begin{array}{l}\text { O jornalismo é tomado } \\
\text { do ponto de vista da } \\
\text { história mundial. O que } \\
\text { implica num } \\
\text { entendimento da } \\
\text { atividade como um viés } \\
\text { que acompanha, frutifica } \\
\text { e é fruto, ao mesmo } \\
\text { tempo, dos } \\
\text { acontecimentos. Assim, } \\
\text { é inevitável que o aluno } \\
\text { perceba suas implicações } \\
\text { com o "ethos" das lutas } \\
\text { pelos direitos humanos, } \\
\text { pela democracia e pela } \\
\text { cidadania. }\end{array}$ \\
\hline
\end{tabular}




\begin{tabular}{|c|c|c|}
\hline $\begin{array}{l}\text { Fundamentos } \\
\text { da Economia } \\
\text { (CJE-506) }\end{array}$ & $\begin{array}{l}\text { Conceitos econômicos fundamentais. } \\
\text { Paradoxos da economia. A atividade } \\
\text { econômica nacional. O produto nacional. } \\
\text { Moedas e relações econômicas } \\
\text { internacionais. Balanço de pagamentos. } \\
\text { Teorias da dependência e do } \\
\text { subdesenvolvimento }\end{array}$ & $\begin{array}{l}\text { As teorias econômicas } \\
\text { definem o mundo pelos } \\
\text { seus modos de } \\
\text { produção. Ao entender } \\
\text { os mecanismos e } \\
\text { paradoxos desses } \\
\text { modos, o aluno é } \\
\text { claramente confrontado } \\
\text { com as desigualdades } \\
\text { sociais entre populações } \\
\text { e nações. Esta dialética } \\
\text { social, por sua vez, é } \\
\text { marca fundamental de } \\
\text { uma cidadania inscrita } \\
\text { numa luta por direitos } \\
\text { baseados em deveres, } \\
\text { como assim a } \\
\text { consideramos. }\end{array}$ \\
\hline $\begin{array}{l}\text { História do } \\
\text { Jornalismo / } \\
\text { Brasil } \\
\text { (CJ E-442) }\end{array}$ & $\begin{array}{l}\text { J ornalismo e desenvolvimento capitalista } \\
\text { no Brasil. História do J ornalismo no Brasil: } \\
\text { periodização, temas e personagens. Os } \\
\text { jornalistas e a censura à informação. Os } \\
\text { jornalistas do século XIX: da } \\
\text { Independência à República. Os jornalistas } \\
\text { dos anos } 30 \text { e } 40: \text { política, censura e } \\
\text { liberdade. Os jornalistas da República } \\
\text { Velha e a defesa dos interesses das elites } \\
\text { e dos trabalhadores. Os jornalistas dos } \\
\text { anos } 50 \text { aos anos } 60: \text { a constituição de um } \\
\text { mercado de trabalho e a ação política e } \\
\text { social. Os jornalistas e o movimento de } \\
64: \text { as opções ideológicas da categoria. Os } \\
\text { jornalistas de } 68 \text { aos anos } 80: \text { as censuras } \\
\text { e as resistências ao arbítrio. A formação } \\
\text { do jornalista no Brasil: das redações e } \\
\text { associações às escolas e aos sindicatos. }\end{array}$ & $\begin{array}{l}\text { O jornalismo é discutido } \\
\text { tendo como pano de } \\
\text { fundo a história do } \\
\text { Brasil; um exercício } \\
\text { fundamental para se } \\
\text { entender as relações } \\
\text { entre poder e imprensa } \\
\text { no País. E mais: os } \\
\text { vieses que marcam o } \\
\text { relacionamento dos } \\
\text { meios de comunicação, o } \\
\text { Estado, o povo brasileiro } \\
\text { e o modelo nacional de } \\
\text { cidadania. }\end{array}$ \\
\hline
\end{tabular}


Os resultados desta primeira fase da pesquisa nos levam a pensar na seguinte direção em relação à habilitação em Jornalismo noturno da ECA / USP:

1. A grade curricular do curso contempla expressamente a formação cidadã do jornalista especialmente nos quatro primeiros semestres;

2. As disciplinas obrigatórias ${ }^{29}$ que expressamente contemplam a cidadania são:

$\checkmark$ No primeiro semestre: Legislação e Deontologia do Jornalismo, Fundamentos Teóricos da História, Pensamento Filosófico e J ornalismo no Rádio e na TV;

$\checkmark$ No segundo semestre: História das Doutrinas Políticas, Ética, Laboratório de I niciação ao Jornalismo e Sociologia da Era Virtual;

$\checkmark$ No terceiro semestre: História do Jornalismo I (Geral) e Fundamentos da Economia;

$\checkmark$ No quarto semestre: História do J ornalismo II (Brasil).

${ }^{29}$ As disciplinas tomadas neste estudo são apenas as de caráter obrigatório. 


\title{
CAPÍ TULO V
}

\section{Dos Discentes e da Produção Laboratorial}

\begin{abstract}
A vida universitária é cercada de muita expectativa por parte dos alunos ingressantes. Os calouros idealizam a formação que irão receber, mesmo conhecendo pouco do cotidiano acadêmico, confiando na 'grife USP' e nos seus mitos. Sonhos de um mundo de conhecimento, com professores preparados e dispostos a transmitir seus ensinamentos, além da existência de uma infra-estrutura suficiente para garantir a qualidade de ensino e de vida dos universitários. Somente a vivência diária no campus traz aos novos estudantes a noção da realidade e, muitas vezes, acaba colocando em questão as impressões que tinham anteriormente.
\end{abstract}

Thomaz Favero, discente da ECA

Expectativas, grife USP, mangas arregaçadas e a certeza de que uma boa formação depende sobretudo do discente, da sua procura. Assim o estudante de jornalismo Thomaz Favero (2004) abre o texto Novos alunos pesam prós e contras da universidade, publicado na edição 281 do Jornal do Campus, de abril de 2004.

O autor consegue captar e expressar muito bem o espírito do estudante uspiano diante das certezas e das incertezas que permearão a sua vida acadêmica e que em tudo condizem com as certezas e incertezas dos alunos de jornalismo ecanos. Nesse espírito, Favero conclui seu artigo:

Mesmo diante do contraste entre as virtudes e os defeitos da universidade, as expectativas dos ingressantes por uma boa carreira acadêmica podem ser alcançadas. O aproveitamento das oportunidades e estrutura oferecidas no campus e o enfrentamento de suas deficiências são alguns dos caminhos. As primeiras impressões devem servir de base para criar algumas novas atitudes com relação ao resto da vida universitária, que está apenas começando. 


\subsection{Dos Laboratórios e do J ornal do Campus}

Programas de rádio, de tv, vídeos-documentários, veículos impressos e digitais, exposições fotográficas. Todo esse material constitui o resultado das produções laboratoriais realizadas como conteúdo das etapas profissionalizantes do curso de J ornalismo da ECA.

Numa área de 323 m2, a ECA abriga um laboratório de redação (LABRI - Sala Vladmir Herzog), um laboratório de rádio-jornalismo (com uma ilha), um laboratório de TV (com estúdio, duas ilhas de edição e um switcher) e um laboratório de fotografia ${ }^{30}$.

$\mathrm{Na}$ área de jornalismo impresso, a revista Babel, o Jornal São Remo e o Jornal do Campus (e seu suplemento Claro!) - constitui, oficialmente, a tríade dos veículos laboratoriais impressos do curso de Jornalismo.

Prestes a completar 24 anos, o J ornal do Campus, estudado nesta dissertação, é elaborado por alunos da disciplina Laboratório em Jornalismo Impresso II sob orientação de um ou de um grupo de professores liderados por um docente. O JC adota, segundo o professor da disciplina José Coelho Sobrinho (2003), três princípios básicos: a defesa da democracia, da universidade pública e do patrimônio da USP.

Com uma periodicidade quinzenal e uma tiragem aproximada de 10.200 jornais, parte dos exemplares do JC é enviada a departamentos e centros acadêmicos e outra parte é distribuída pelos próprios alunos de Jornalismo nos campi da universidade.

Os custos da impressão do jornal são cobertos em parte pelo próprio Departamento de Jornalismo e uma outra parte pela Editora Globo, que a cada edição tem uma peça de meia página publicada.

\footnotetext{
${ }^{30}$ ECA: USP. Cadastro Predial da Escola de Comunicações e Artes. Folha 01. Coordenadoria do Espaço Físico da USP. São Paulo, outubro de 2004.
} 
Atualmente o JC é impresso em papel jornal e policromia offset, tem formato fechado $32 \times 56 \mathrm{~cm}$ e apresenta oito páginas ${ }^{31}$. 0 jornal usa em seus textos e títulos tipologia primordialmente serifada da família romana, com destaque para as fontes Times e Garamond. Nos créditos e legendas predomina a família lapidária, com destaque para a fonte Arial.

As fotos, a maioria feita pelos próprios alunos, têm um caráter informativo, complementando a informação da matéria. As charges, que geralmente ocupam a página de Debates, são feitas por membros da comunidade uspiana, como colaboração. Entre os recursos visuais, merece destaque o uso de infográficos com o objetivo de detalhar as informações constantes nas matérias. O sistema de paginação predominante é o vertical com três, cinco ou seis colunas.

Além dos laboratórios, um ponto de apoio importante para docentes e discentes ecanos é a biblioteca da escola. Além de material eletrônico sonoro e audiovisual, a Biblioteca da ECA disponibiliza mais de 10.489 títulos entre livros, periódicos, trabalhos de conclusão de curso, dissertações e teses ${ }^{32}$.

\footnotetext{
${ }^{31}$ Algumas edições trazem encartado o caderno Claro!, do qual falaremos mais adiante.

32 ECA: USP. Serviço de Biblioteca e Documentação. Disponível em: http://www.rebeca.eca.usp.br/.
} 


\subsection{Da Apresentação e Análise dos Dados da Pesquisa}

Nesta segunda fase da pesquisa dois estudos foram realizados paralelamente. Com autorização do docente e dos discentes, acompanhamos durante o primeiro semestre de 2004 o processo de produção de seis edições do Jornal do Campus - 281 a 286 (apêndice 01) - na disciplina Laboratório de J ornalismo I mpresso II.

Num primeiro momento, ao passo em que acompanhamos a produção das edições, verificamos o aparecimento ou não do que entendemos por conteúdo cidadão na produção laboratorial dos alunos. Num segundo momento, a partir dessa análise, realizamos entrevistas com alguns dos discentes envolvidos no processo.

Nos dois momentos desta segunda etapa da pesquisa destacamos conteúdos relacionados aos direitos humanos, à democracia, à ética profissional e à responsabilidade social do jornalismo.

Consideramos como amostra a produção laboratorial e os alunos do quinto semestre por entendermos que esses poderiam melhor refletir e discutir a aplicação de um conteúdo voltado à cidadania recebido curricularmente de forma mais intensa nos quatro primeiros semestres, conforme havíamos constatado na etapa anterior deste trabalho.

\section{Editorias}

O JC tem como público-alvo a população da USP, considerando seus corpos discente, docente e técnico-administrativo. Assim, editorialmente o veículo aborda primordialmente questões relacionadas à comunidade acadêmica uspiana, agregando às matérias, na maioria das vezes, um forte tom político-social. Nas seis edições analisadas, o jornal apresentava cinco editorias:

1. Debate: em uma página, a editoria discute, em artigo assinado por um aluno da turma, temas polêmicos para a comunidade. Além 
disso, apresenta um fórum com o posicionamento de membros da comunidade sobre o assunto, uma charge, uma pequena seção de cartas e outra de notas, e uma 'Memória do Campus' como fotos que retratam o passado da Universidade. Não há, no jornal, espaço para editorial. Segundo o professor Coelho, esta é uma deliberação do Conselho Departamental e fundamenta-se no fato de não haver jornalistas fixos no JC.

2. Esporte: editoria de uma página que retrata a vida esportiva da comunidade uspiana. Em três ou quatro matérias a editoria destaca torneios e eventos que ocorrem no campus ou dos quais membros da comunidade, geralmente alunos, participam.

3. Entrevista: uma página dedicada a entrevistas com personalidades da USP, retratando temas de ordem política.

4. Cultura: a última página do jornal é dedicada à cultura. Traz três ou quatro matérias tratando de exposições, mostras, eventos e artistas da comunidade acadêmica e uma agenda cultural.

5. Universidade: editoria central do JC, ocupa três páginas - 03, 04 e 05 - de cada edição e apresenta o desenvolvimento da manchete na página 03. Abriga seis ou sete matérias, a coluna de ombudsman; uma coluna intitulada Identidade, sempre apresentando uma personalidade professor ou técnico - que faz parte da história da USP e, finalmente, a coluna In Loco, que traz matérias mais leves com curiosidades sobre o que acontece no espaço físico do campus.

\section{Amostra das entrevistas}

Com a idéia de vincular o aluno entrevistado à sua produção laboratorial, a amostra - por edição ${ }^{33}$ - foi formada pelos alunos que se revezavam na secretaria de redação (geralmente um aluno), por aqueles cuja matéria era manchete (um ou dois alunos), por aqueles

\footnotetext{
${ }^{33}$ Foi combinado previamente, pela turma, que as equipes se revezariam a cada duas edições. Assim, temos a mesma equipe (incluindo secretário de redação) para as edições 281 e 282; 283 e 284 e, finalmente, 285 e 286 .
} 
cuja matéria ocupava maior espaço na edição (geralmente dois alunos, nesta categoria permaneceram sempre as entrevistas) e por aqueles cuja matéria mais possibilitava discussões sobre cidadania (geralmente um aluno).

A análise da produção laboratorial do Jornal do Campus como fundamento para as entrevistas com os alunos ateve-se, a rigor, aos textos das reportagens. No entanto, algumas questões extratextuais, como os aspectos didáticos ${ }^{34}$ adotados pelo professor e a conduta dos alunos envolvidos não puderam deixar de ser considerados e constam nas conclusões deste item da pesquisa.

Das seis edições analisadas, três - 281, 283 e 285 - tiveram um total de oito páginas e as edições pares - 282, 284 e 286 - tiveram, além desse total, mais um caderno tablóide, que funciona como um encarte, o caderno Claro!, produzido por uma outra turma do curso de Jornalismo sob orientação da professora Nancy N. Ali Ramadan ${ }^{35}$.

De uma forma geral os alunos entrevistados apresentam uma boa idéia da responsabilidade do jornalismo, tanto no que diz respeito aos prazos quanto à clareza e qualidade da informação.

Nos quadros a seguir, cada um relacionado a uma edição específica do JC, após apresentarmos a categoria analisada, o discente entrevistado e a sua opinião sobre o tema pesquisado, registramos nossas reflexões.

\footnotetext{
${ }^{34}$ Segundo Ramadan (2003), a didática corresponde "aos instrumentos dos quais nos utilizamos em aula para o processo de aprendizagem (...) tendo em vista o discente - e a si mesmo - como pessoa completa, agente da construção do conhecimento". A respeito do conceito, Coelho (2002) observa que a didática “deixou de ser uma técnica para transformar-se numa estratégia (...). Deixou de lado a sua função normativa e se transformou no campo da prática das relações de apreensão da construção do saber, isto é, ela se transformou adquirindo a função de integrar os diferentes elementos facilitadores da edificação do saber".

${ }_{35}$ Por opção metodológica, achamos por bem não avaliar esse segundo material por ser produzido por uma outra turma.
} 
Edição 281 (anexo 03), São Paulo, 1o a 21 de abril de 2004

\begin{tabular}{|c|c|c|c|c|c|}
\hline \multicolumn{3}{|c|}{ Categoria analisada } & $\begin{array}{l}\text { Discente } \\
\text { entrevistado }\end{array}$ & Opinião do discente entrevistado & $\begin{array}{l}\text { Relação com a } \\
\text { cidadania }\end{array}$ \\
\hline \multirow{2}{*}{$\begin{array}{l}\mathbf{M} \\
\mathbf{A} \\
\mathbf{N} \\
\mathbf{C} \\
\mathbf{H} \\
\mathbf{E} \\
\mathbf{T} \\
\mathrm{E}\end{array}$} & \begin{tabular}{|l|} 
Editoria \\
\end{tabular} & Universidade & \multirow{2}{*}{$\begin{array}{l}\text { Julia Tavares, } \\
22 \text { anos }\end{array}$} & \multirow{2}{*}{$\begin{array}{l}\text { A princípio, quando a gente começou a pensar na pauta (sobre } \\
\text { os novos cursos a serem oferecidos pela USP Zona Leste, como } \\
\text { Gerontologia e Gestão Ambiental) eu já parti para campo com } \\
\text { um pé atrás e já estava preocupada. Acho que isso foi uma } \\
\text { coisa que aprendi ao longo do curso de Jornalismo, de ouvir os } \\
\text { diferentes lados. No final eu acho que consegui fazer uma } \\
\text { matéria equilibrada. Uma entrevista que me ajudou muito e } \\
\text { que foi muito importante foi com o professor Aziz Al Azmed. } \\
\text { (...) } \\
\text { Claro que na faculdade a gente tem muitas discussões (sobre } \\
\text { "ouvir dos dois lados"), até mesmo na hora de discutir as } \\
\text { pautas. Mas essa concepção de ética você traz da infância, da } \\
\text { sua formação desde sempre. Vem da sua formação cultural, do } \\
\text { ambiente onde você nasceu... Eu não acho que tudo vem do } \\
\text { curso de Jornalismo. }\end{array}$} & \multirow{2}{*}{$\begin{array}{l}\text { A aluna toca num } \\
\text { princípio básico da } \\
\text { ética e da } \\
\text { responsabilidade } \\
\text { social do jornalismo: } \\
\text { a checagem. Ao } \\
\text { refletir sobre a } \\
\text { atenção que deve ser } \\
\text { dada aos diferentes } \\
\text { lados de uma mesma } \\
\text { matéria como } \\
\text { aprendizado formal do } \\
\text { jornalismo, a aluna } \\
\text { referenda a cidadania } \\
\text { como pré-requisito da } \\
\text { sua prática } \\
\text { profissional. }\end{array}$} \\
\hline & $\begin{array}{l}\text { Título da } \\
\text { chamada }\end{array}$ & $\begin{array}{l}\text { Cursos da ZL } \\
\text { causam } \\
\text { polêmica }\end{array}$ & & & \\
\hline
\end{tabular}




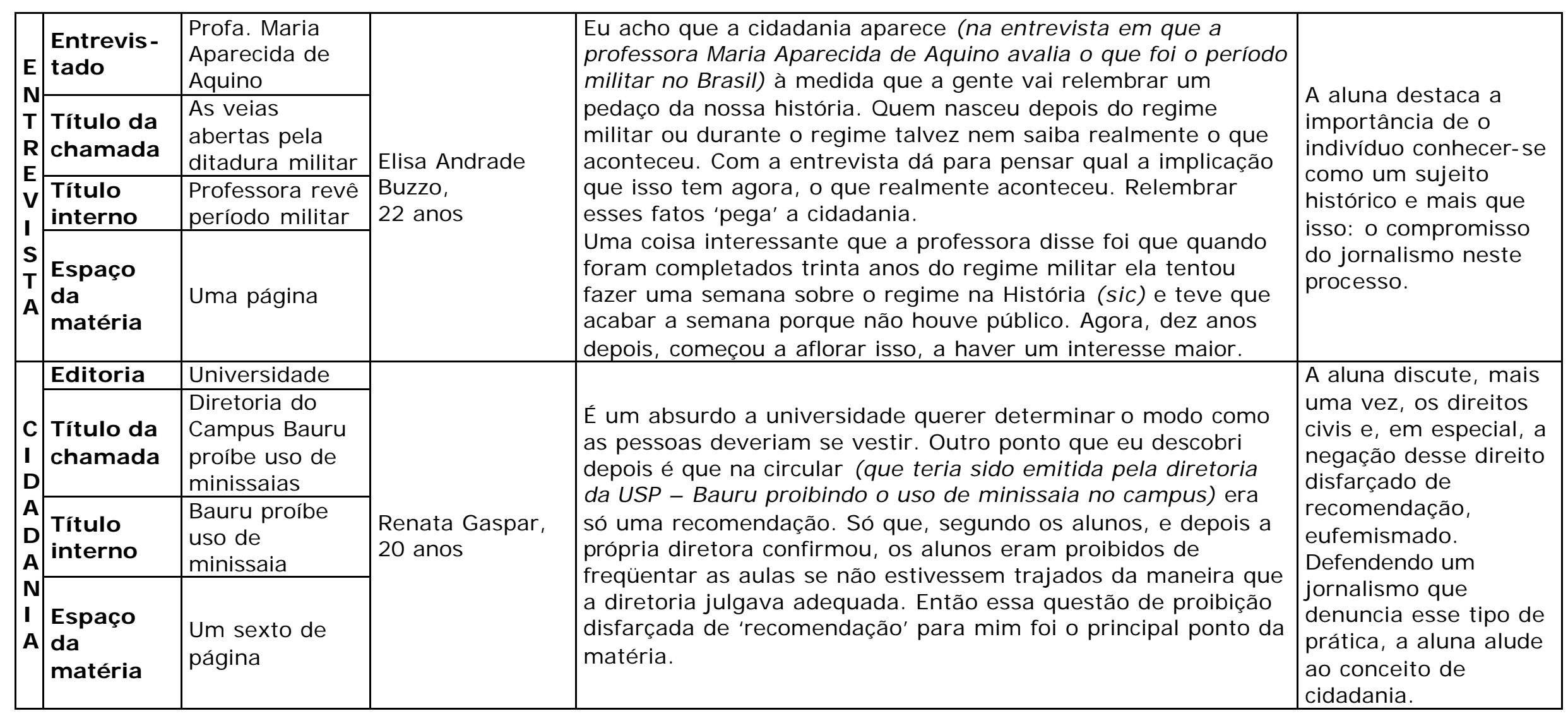


Edição 282 (anexo 04), São Paulo, 22 de abril a 05 de maio de 2004

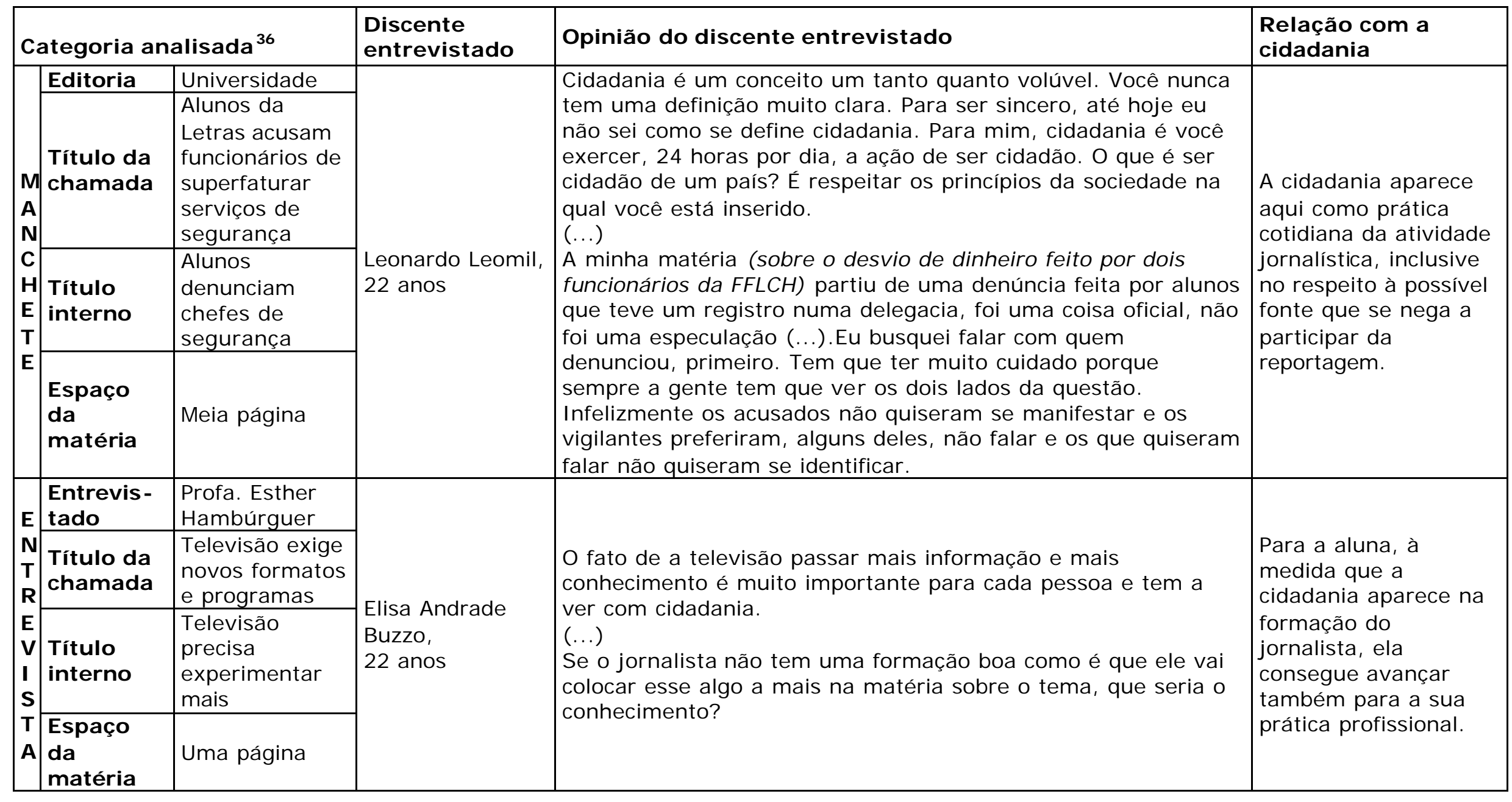

${ }^{36} \mathrm{O}(\mathrm{A})$ secretário (a) de redação foi entrevistado a cada duas edições, período em que os alunos se revesavam no cargo. 


\begin{tabular}{|c|c|c|c|c|c|}
\hline & Editoria & Universidade & \multirow{3}{*}{$\begin{array}{l}\text { Renata Gaspar, } \\
20 \text { anos }\end{array}$} & \multirow{3}{*}{$\begin{array}{l}\text { Na verdade acredito que manter a isenção seja extremamente } \\
\text { difícil, e talvez impossível, porque os seus pressupostos e } \\
\text { visões de mundo estão inseridos, mesmo que indiretamente, } \\
\text { na hora de selecionar as fontes, escolher quais palavras } \\
\text { utilizar, o que editar etc. Porém, você deve sempre tentar ouvir } \\
\text { pessoas que representem os vários aspectos envolvidos na } \\
\text { questão e tentar dar a essas correntes o mesmo espaço para o } \\
\text { debate. Na matéria (sobre a substituição do Provão pelo } \\
\text { Enade), consegui falar com uma pessoa do Inep, que } \\
\text { representava a posição do governo, a professora Eunice } \\
\text { Durhan, que se dedica ao assunto e a questões relacionadas ao } \\
\text { estudo, e com os alunos, representados pelo DCE. } \\
\text { Por incrível que pareça, falar com os alunos foi a parte mais } \\
\text { difícil, porque os centros acadêmicos diziam que ainda não } \\
\text { tinham posição formada e o DCE dizia que a pessoa que } \\
\text { poderia falar sobre isso não estava. Depois de duas semanas } \\
\text { de insistência consegui falar com um membro do DCE, mas, } \\
\text { devido à correria, não foi tão produtivo. }\end{array}$} & \multirow{3}{*}{$\begin{array}{l}\text { O respeito às fontes e } \\
\text { ao trabalho de } \\
\text { entrevista aparecem } \\
\text { como elementos } \\
\text { claros de uma prática } \\
\text { jornalística } \\
\text { responsável } \\
\text { comprometida com os } \\
\text { direitos e com os } \\
\text { deveres do cidadão. }\end{array}$} \\
\hline & $\begin{array}{l}\text { Título e } \\
\text { chamada } \\
\text { de capa }\end{array}$ & $\begin{array}{l}\text { Governo } \\
\text { Federal institui } \\
\text { novo sistema } \\
\text { de avaliação do } \\
\text { ensino superior }\end{array}$ & & & \\
\hline & \begin{tabular}{|l} 
Título \\
interno
\end{tabular} & $\begin{array}{l}\text { Lula aprova } \\
\text { substituição do } \\
\text { provão }\end{array}$ & & & \\
\hline
\end{tabular}


Edição 283 (anexo 05), São Paulo, 06 a 19 de maio de 2004

\begin{tabular}{|c|c|c|c|c|c|}
\hline \multicolumn{3}{|c|}{ Categoria analisada } & $\begin{array}{l}\text { Discente } \\
\text { entrevistado }\end{array}$ & Opinião do discente entrevistado & $\begin{array}{l}\text { Relação com a } \\
\text { cidadania }\end{array}$ \\
\hline \multicolumn{3}{|c|}{ Secretário de redação } & $\begin{array}{l}\text { Yara Camargo, } \\
19 \text { anos }\end{array}$ & $\begin{array}{l}\text { A gente sempre tentou se pautar para fazer o jornal o mais } \\
\text { quente possível. Porque é um jornal quinzenal e é difícil } \\
\text { conseguir fazê- lo sempre quente. Fomos até muito elogiados } \\
\text { por causa disso. } \\
\text { (...) } \\
\text { A gente se propôs a ter um ritmo de trabalho um pouco } \\
\text { diferente, que seria um jornal quinzenal para poder trazer } \\
\text { notícias mais atuais e que tivessem bastante interesse para a } \\
\text { comunidade da USP em geral: alunos, funcionários e quem } \\
\text { mais fosse ler. }\end{array}$ & $\begin{array}{l}\text { Aqui a cidadania } \\
\text { aparece como } \\
\text { respeito à atualidade } \\
\text { da informação e ao } \\
\text { leitor. }\end{array}$ \\
\hline \multirow{4}{*}{$\begin{array}{l}\text { M } \\
\text { A } \\
\mathbf{N} \\
\mathbf{C} \\
\mathbf{H} \\
\mathbf{E} \\
\mathbf{T} \\
\mathbf{E}\end{array}$} & Editoria & Universidade & \multirow{4}{*}{$\begin{array}{l}\text { Paulo Fehlauer, } \\
22 \text { anos }\end{array}$} & \multirow{4}{*}{$\begin{array}{l}\text { Uma matéria se torna panfletária à medida que você defende } \\
\text { apenas um interesse; o interesse de quem você representa. } \\
\text { Então, se você, mesmo tendo esse ponto de vista, buscar as } \\
\text { outras visões, ela vai ficar menos panfletária, menos parcial e } \\
\text { mostra uma preocupação em não tornar o texto um mero } \\
\text { panfleto. } \\
\text { (...) } \\
\text { O lide (da matéria sobre a suspensão reunião do Conselho } \\
\text { Universitário aberto à comunidade e que discutia as fundações } \\
\text { na USP) talvez tenha sido um pouco exagerado, porque era } \\
\text { uma idéia que eu tinha antes de fazer a matéria, não prevendo } \\
\text { o que aconteceu (a suspensão), mas um pouco relacionado } \\
\text { com a charge que a gente fez, que era chamar aquela reunião } \\
\text { de circo porque ela foi montada. Essa era a opinião de muitos } \\
\text { estudantes que depois se manifestaram. Ainda tem aquele caso } \\
\text { da Reitoria: não adianta procurá- los porque eles não } \\
\text { respondem, esse é um outro problema. Mas eu procurei as } \\
\text { pessoas, gente do DCE, professores e conversei com alunos. }\end{array}$} & \multirow{4}{*}{$\begin{array}{l}\text { A discussão dos } \\
\text { interesses pessoais } \\
\text { sobre os sociais - o } \\
\text { imperativo categórico } \\
\text { de Kant - põe na } \\
\text { ordem do dia a } \\
\text { valorização da } \\
\text { cidadania. A isso } \\
\text { adicionado, numa } \\
\text { perspectiva rogeriana, } \\
\text { o aprendizado que } \\
\text { abre brechas para a } \\
\text { autocrítica e o } \\
\text { reconhecimento de } \\
\text { limites por parte do } \\
\text { aluno. }\end{array}$} \\
\hline & $\begin{array}{l}\text { Título da } \\
\text { chamada }\end{array}$ & \begin{tabular}{|l} 
Protestos e \\
confusão \\
marcam \\
reunião aberta \\
do Conselho \\
sobre \\
fundações
\end{tabular} & & & \\
\hline & $\begin{array}{l}\text { Título } \\
\text { interno }\end{array}$ & $\begin{array}{l}\text { Reitor } \\
\text { suspende Co } \\
\text { aberto mais } \\
\text { cedo }\end{array}$ & & & \\
\hline & $\begin{array}{l}\text { Espaço } \\
\text { da } \\
\text { matéria }\end{array}$ & $\begin{array}{l}\text { Dois terços de } \\
\text { página }\end{array}$ & & & \\
\hline
\end{tabular}




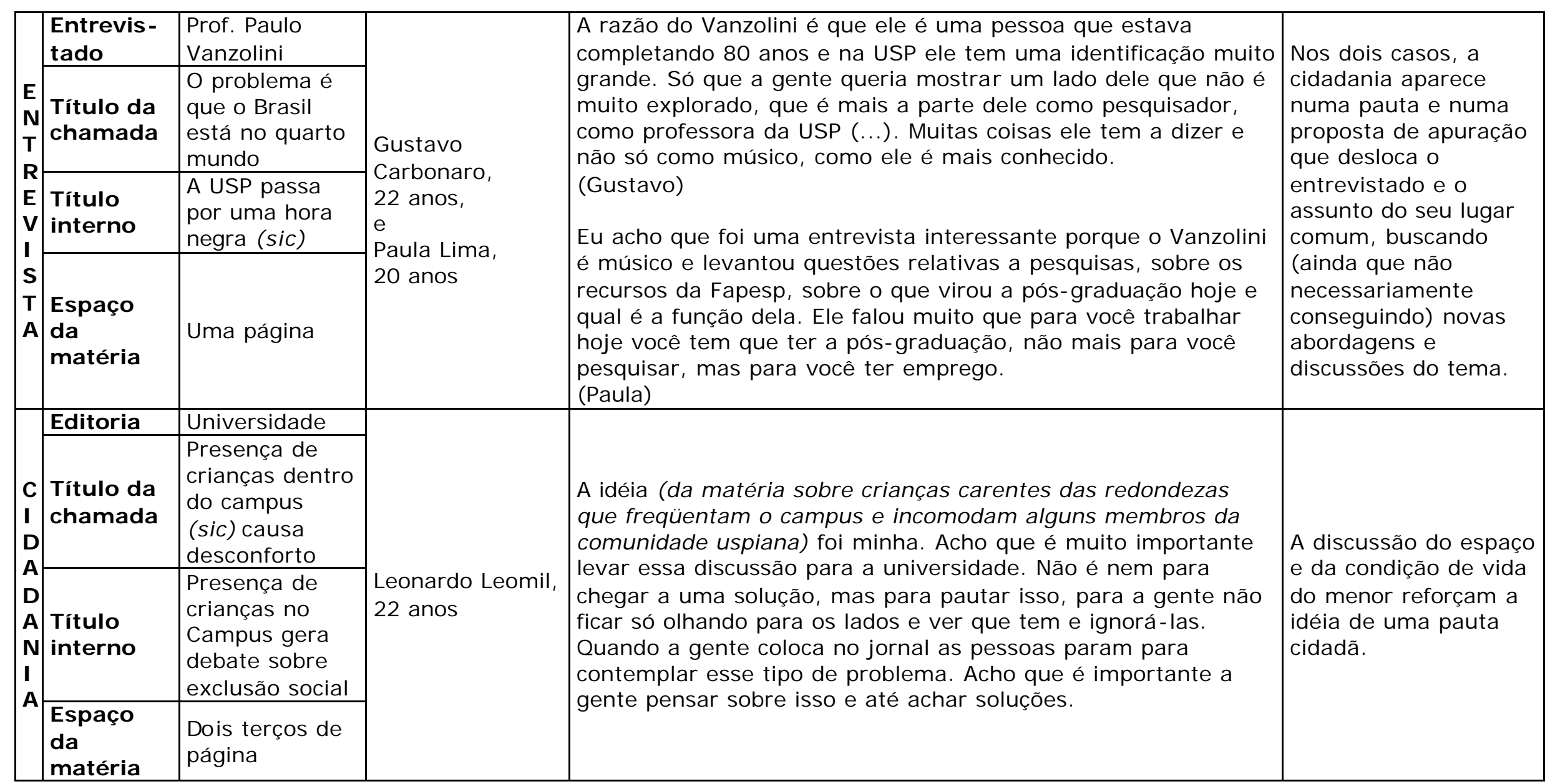


Edição 284 (anexo 06), São Paulo, 21 de maio a 03 de junho de 2004

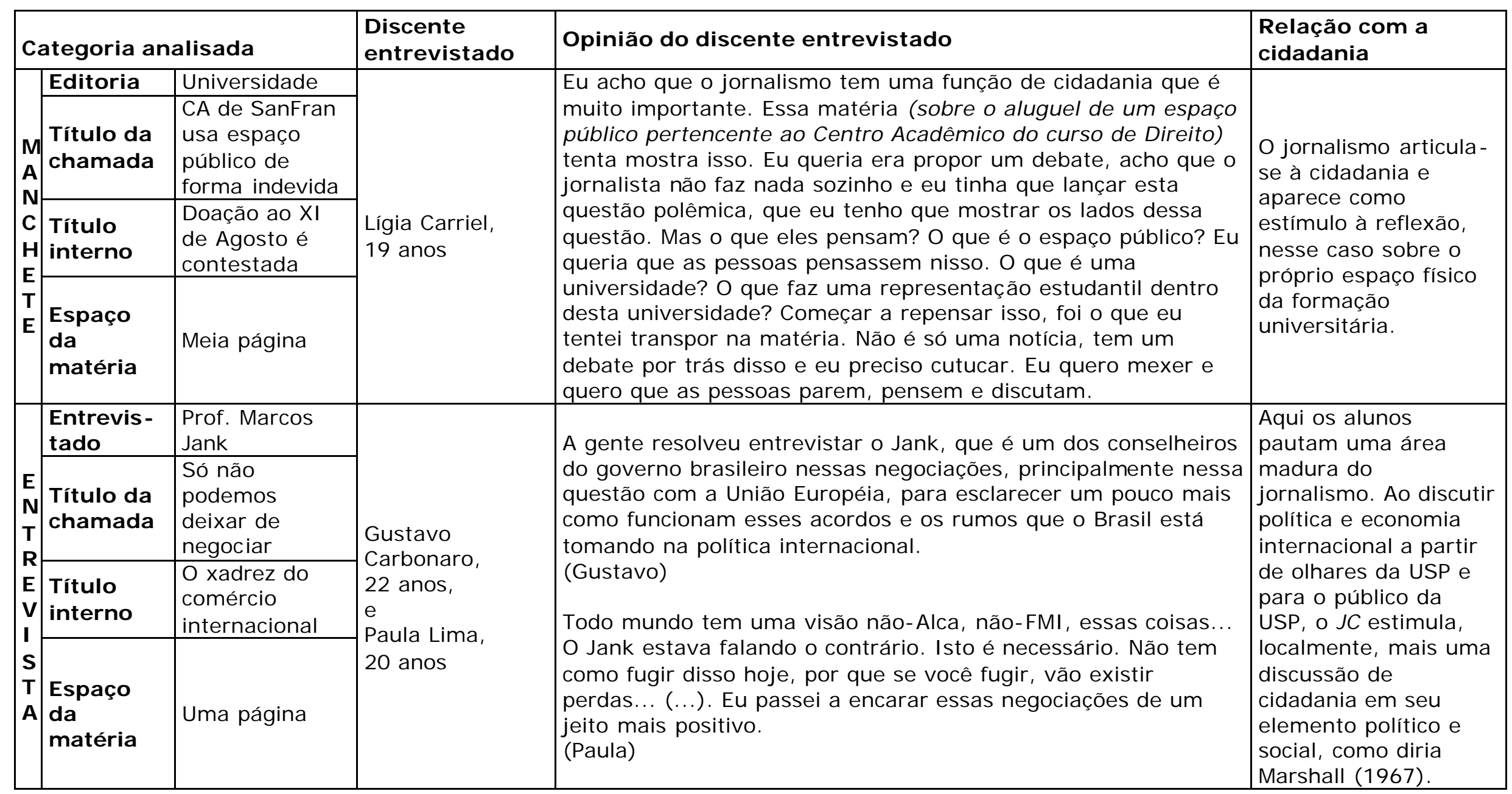




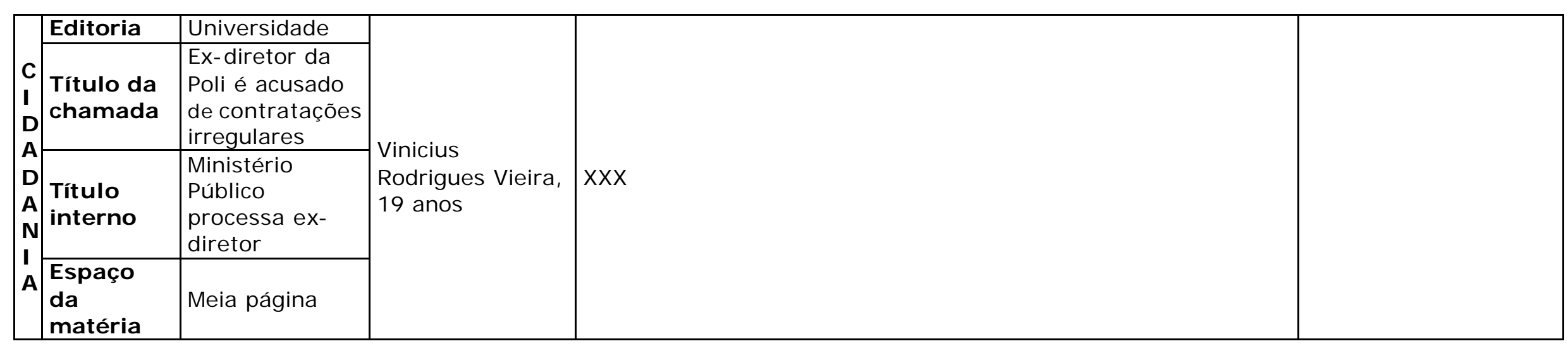

\section{Caderno Especial Manifestação de 20 de maio [Parte integrante da edição 284 (anexo 07 )]}

A edição 284 traz um caderno especial sobre a paralisação dos docentes e funcionários da USP, Unicamp e Unesp ocorrida em 20 de maio de 2004. Por tratar-se de um suplemento, o material não apresenta as editorias das edições convencionais, o que implicou também numa análise mais sucinta. 


\begin{tabular}{|c|c|c|c|}
\hline $\begin{array}{l}\text { Secretário } \\
\text { de redação }\end{array}$ & $\begin{array}{l}\text { Yara } \\
\text { Camargo, } \\
19 \text { anos }\end{array}$ & $\begin{array}{l}\text { A idéia principal era dar uma cobertura de greve, mas não queríamos } \\
\text { pender só para o lado do Sintusp, porque isso é muito lugar comum. A } \\
\text { gente queria mostrar o clima que estava rolando porque desde } 2000 \text { a } \\
\text { gente não tem uma greve forte. E esta está com um clima que vai ser } \\
\text { uma greve forte e tem muita gente dentro das unidades da USP que nem } \\
\text { sabe disso. } \\
\text { (...) } \\
\text { Quando tem greve, o que acontece? ECA, FFLECH, essas faculdades das } \\
\text { Ciências Humanas são as primeiras a parar. Elas sempre param, até } \\
\text { porque tem o Sintusp aqui do lado, uma questão até mesmo geográfica. } \\
\text { Mas na Odonto, na Farmácia, que ficam lá do outro lado do Campus, o } \\
\text { Sintusp já não tem tanta força. A gente queria também levar essas } \\
\text { informações para esses lugares que estão longe, como a Medicina, o São } \\
\text { Francisco, por exemplo, que são fora do campus. A idéia principal era } \\
\text { fazer com que as pessoas se ligassem que está rolando um movimento } \\
\text { forte. }\end{array}$ & $\begin{array}{l}\text { Independentemente da força da } \\
\text { greve, merece destaque a } \\
\text { pujança do jornalismo nessa } \\
\text { cobertura. O ímpeto, associado a a } \\
\text { valores como a responsabilidade } \\
\text { de informar e uma clara e } \\
\text { assumida postura em defesa da } \\
\text { instituição pública, fazem com a } \\
\text { que a cobertura transpire } \\
\text { cidadania. }\end{array}$ \\
\hline
\end{tabular}


Edição 285 (anexo 08), São Paulo, 04 a 17 de junho de 2004

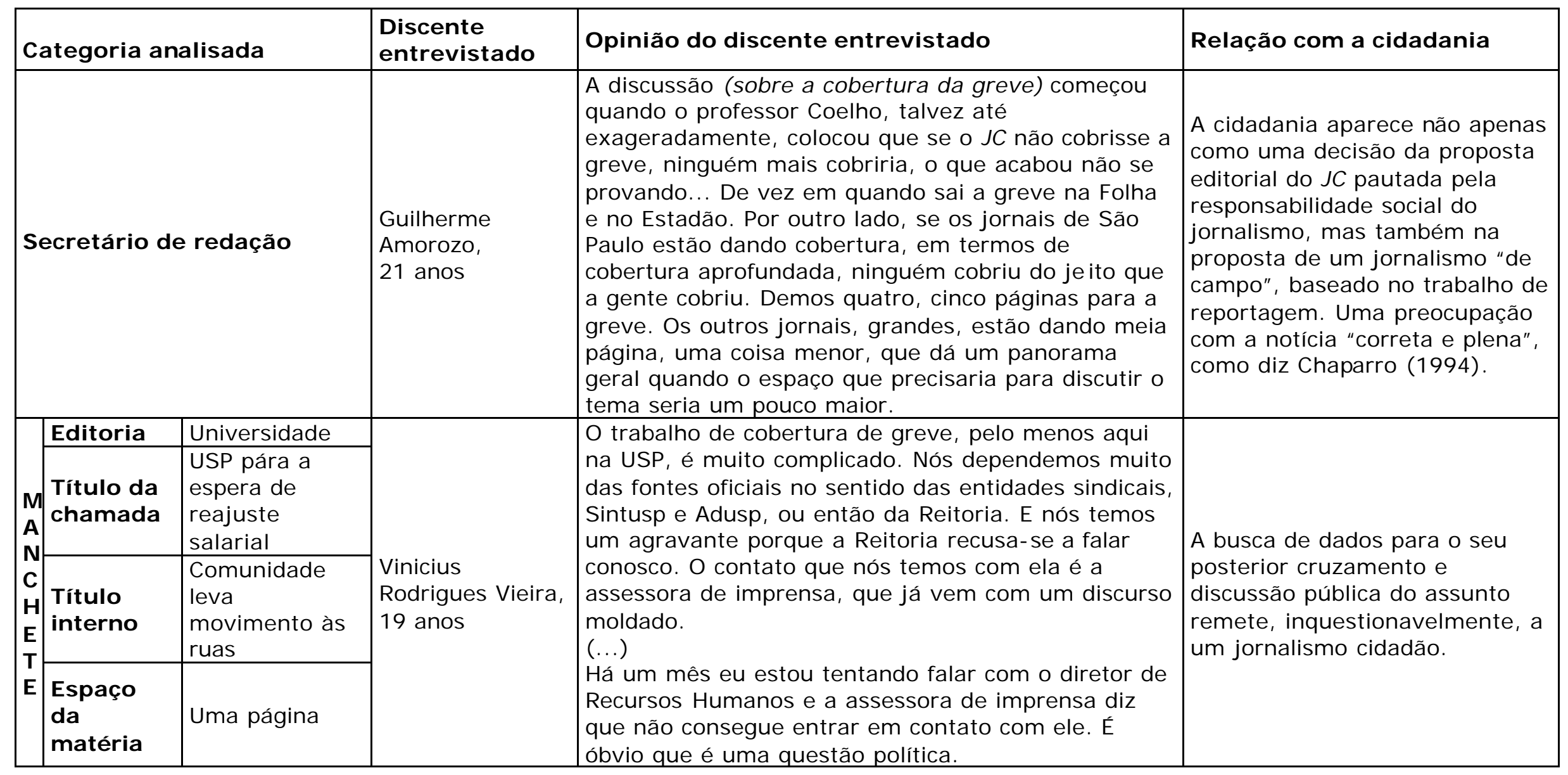




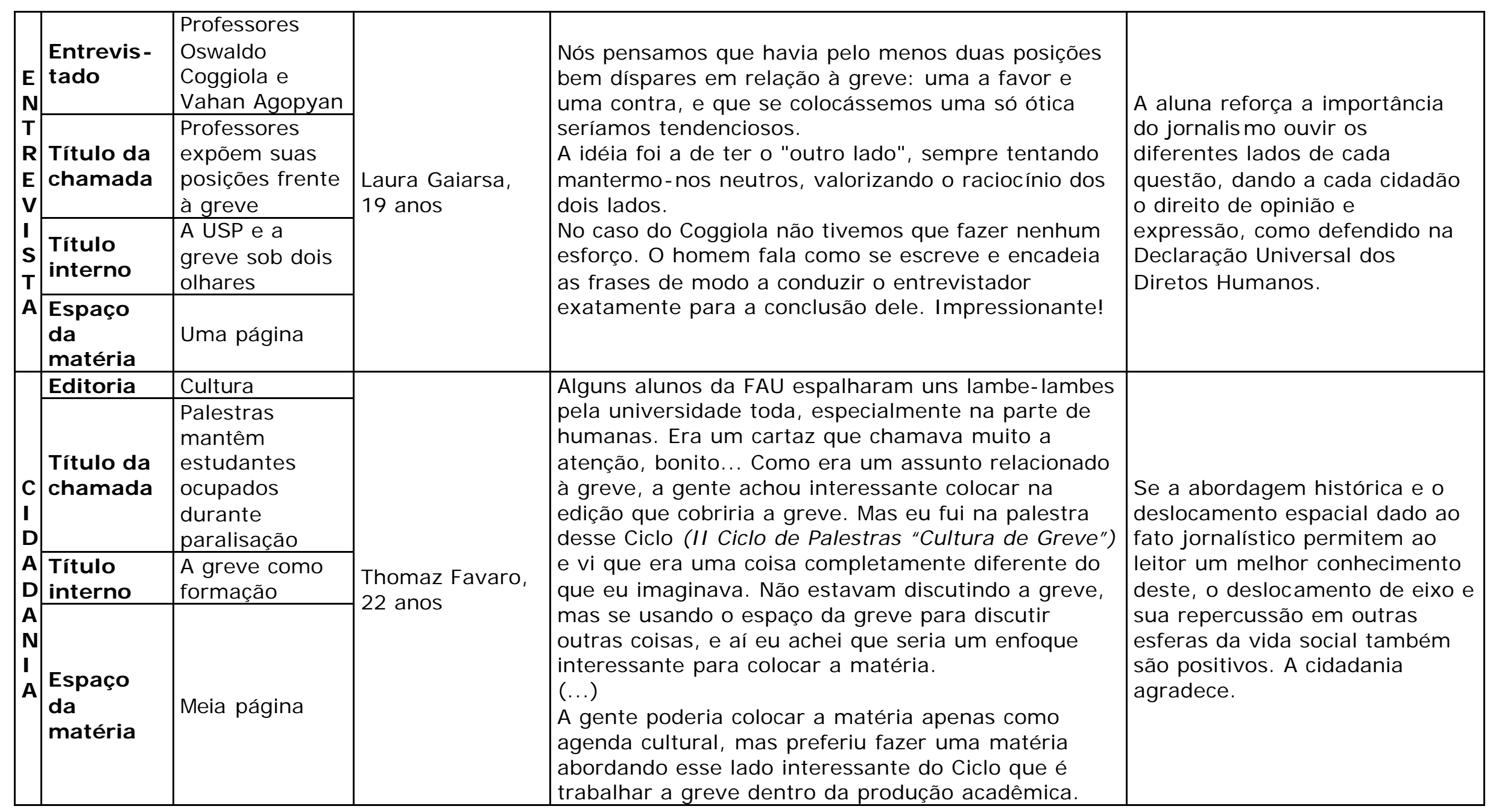


Edição 286 (anexo 09), São Paulo, 25 de junho a 09 de julho de 2004

\begin{tabular}{|c|c|c|c|c|c|}
\hline \multicolumn{3}{|c|}{ Categoria analisada } & $\begin{array}{l}\text { Discente } \\
\text { entrevistado }\end{array}$ & Opinião do discente entrevistado & Relação com a cidadania \\
\hline & Editoria & Universidade & \multirow{4}{*}{$\begin{array}{l}\text { Vinicius } \\
\text { Rodrigues Vieira, } \\
19 \text { anos }\end{array}$} & \multirow{4}{*}{$\begin{array}{l}\text { O Carlos Fino participou da cobertura da Guerra do } \\
\text { Iraque e veio dar uma palestra aqui no CJ E. Ele } \\
\text { disse que quando a União Européia se formou, em } \\
\text { Bruxelas, chefes de Estado se reuniram e os } \\
\text { jornalistas ficaram fora de reunião que culminou no } \\
\text { acordo final para a constituição da UE. Os jornalistas } \\
\text { só registraram aquilo que os chefes de Estado } \\
\text { disseram, ou seja, aquilo que eles combinaram entre } \\
\text { eles. Então o jornalismo perde, perde em } \\
\text { profundidade, perde à medida que você não pode } \\
\text { acompanhar os processos decisórios. Você apenas } \\
\text { acompanha os resultados, o produto e o produto, } \\
\text { sem dúvida, pode estar camuflado, tal como o } \\
\text { Carlos Fino deu a entender. }\end{array}$} & \multirow{4}{*}{$\begin{array}{l}\text { O aluno ressalta a importância } \\
\text { do trabalho de cobertura. Com } \\
\text { base em Carlos Fino } 37 \text {, ele } \\
\text { reconhece que ao jornalismo } \\
\text { não cabe esperar os dados, } \\
\text { mas acompanhar sua } \\
\text { compilação. Ponto para um } \\
\text { jornalismo que transcorre em } \\
\text { ambientes democráticos e que } \\
\text { é pautado pela ética e pela } \\
\text { responsabilidade social da } \\
\text { profissão. }\end{array}$} \\
\hline & $\begin{array}{l}\text { Título da } \\
\text { chamada }\end{array}$ & $\begin{array}{l}\text { Negociadores } \\
\text { mantêm } \\
\text { impasse e } \\
\text { greve segue } \\
\text { com adesão } \\
\text { parcial de } \\
\text { alunos }\end{array}$ & & & \\
\hline & $\begin{array}{l}\text { Título } \\
\text { interno }\end{array}$ & $\begin{array}{l}\text { Cruesp pede } \\
\text { contraproposta } \\
\text { ao Fórum }\end{array}$ & & & \\
\hline & $\begin{array}{l}\text { Espaço } \\
\text { da } \\
\text { matéria }\end{array}$ & Uma página & & & \\
\hline \multirow{4}{*}{$\begin{array}{l}\mathbf{E} \\
\mathbf{N} \\
\mathbf{T} \\
\mathbf{R} \\
\mathbf{E} \\
\mathbf{V} \\
\mathbf{I} \\
\mathbf{S} \\
\mathbf{T} \\
\mathbf{A}\end{array}$} & $\begin{array}{l}\text { Entrevis- } \\
\text { tado }\end{array}$ & $\begin{array}{l}\text { Prof. Lucio } \\
\text { Gomes } \\
\text { Machado }\end{array}$ & \multirow{4}{*}{$\begin{array}{l}\text { Laura Gaiarsa, } \\
19 \text { anos }\end{array}$} & \multirow{4}{*}{$\begin{array}{l}\text { O paulistano é bem desligado de sua cidade. Acho } \\
\text { que o que vale aqui é a propriedade de cada um, e } \\
\text { cada um tentando manter os outros bem longe dela. } \\
\text { Não há uma relação de afeto com a cidade, mas de } \\
\text { utilitarismo e imediatismo. Acho que o jornalismo } \\
\text { tem responsabilidade nisso, pois deveria fazer mais } \\
\text { foco nas questões de cidadania, chamar a atenção } \\
\text { para medidas e ações que valorizem o espaço e a } \\
\text { coisa pública. E denunciar os abusos contra a } \\
\text { cidadania, sempre que possível. }\end{array}$} & \multirow{4}{*}{$\begin{array}{l}\text { A aluna põe por terra um dos } \\
\text { mitos da cidadania e deixa } \\
\text { claro que a ela não implica só } \\
\text { em direitos, mas também em } \\
\text { deveres. Assim, a matéria } \\
\text { contempla o dever do cidadão } \\
\text { responsabilizar-se pela cidade } \\
\text { onde vive. }\end{array}$} \\
\hline & $\begin{array}{l}\text { Título da } \\
\text { chamada }\end{array}$ & $\begin{array}{l}\text { Problemas de } \\
\text { São Paulo } \\
\text { pedem } \\
\text { compromisso } \\
\text { geral }\end{array}$ & & & \\
\hline & $\begin{array}{l}\text { Título } \\
\text { interno }\end{array}$ & $\begin{array}{l}\text { A } \\
\text { reestruturação } \\
\text { de São Paulo }\end{array}$ & & & \\
\hline & $\begin{array}{l}\text { Espaço } \\
\text { da } \\
\text { matéria }\end{array}$ & Uma página & & & \\
\hline
\end{tabular}

${ }^{37}$ J ornalista português com experiências em coberturas de guerra e política internacional. 


\begin{tabular}{|c|c|c|c|c|c|}
\hline & Editoria & ultura & & \multirow{4}{*}{$\begin{array}{l}\text { Seria interessante, na minha opinião, se a matéria } \\
\text { fosse para discutir o tema, como foi o movimento } \\
\text { que a gente trouxe na edição passada: cultura de } \\
\text { greve. Então vamos aproveitar e trazer as pessoas } \\
\text { para a universidade, porque greve não é férias. } \\
\text { Vamos discutir o assunto que está rolando na } \\
\text { universidade. O problema dessa matéria é que os } \\
\text { órgãos não têm a ver com greve mesmo. } \\
\text { (...) } \\
\text { Muitos desses museus não são ligados à } \\
\text { universidade. O Espaço das Artes, o Museu do Crime } \\
\text { estão na Cidade Universitária, mas não são da USP. } \\
\text { Não faria sentido eles pararem. O intuito mesmo era } \\
\text { trazer as pessoas para o campus. }\end{array}$} & \multirow{4}{*}{$\begin{array}{l}\text { O jornal produziu uma matéria } \\
\text { que pouco fez referência ao } \\
\text { acontecimento de maior } \\
\text { repercussão na universidade: a } \\
\text { greve. No entanto, ocupou o } \\
\text { espaço da editoria de cultura } \\
\text { para apresentar o que poderia } \\
\text { render, numa edição posterior, } \\
\text { uma boa matéria sobre as } \\
\text { instituições que não param } \\
\text { porque, apesar de estarem na } \\
\text { USP, não são da USP. }\end{array}$} \\
\hline & $\begin{array}{l}\text { Títu lo da } \\
\text { chamada }\end{array}$ & \begin{tabular}{|l|} 
Eventos \\
culturais \\
seguem ativos \\
durante \\
paralisação
\end{tabular} & & & \\
\hline & $\begin{array}{l}\text { Título } \\
\text { interno }\end{array}$ & $\begin{array}{l}\text { A USP que não } \\
\text { pára com a } \\
\text { greve }\end{array}$ & & & \\
\hline & $\begin{array}{l}\text { Espaço } \\
\text { da } \\
\text { matéria }\end{array}$ & Uma página & & & \\
\hline
\end{tabular}


Os resultados das entrevistas com os discentes levando também em consideração a produção laboratorial do Jornal do Campus, nos levam ao seguinte resultado em relação à habilitação em Jornalismo noturno da ECA / USP:

1. Os conceitos de cidadania aparecem na relação do discente com o mundo e a experiência acadêmica.

Na edição 281 do JC (2004: 03), num texto de apresentação da ombudsman elaborado pelos alunos, os discentes evidenciam a preocupação com 0 trabalho do "ouvidor" que se coloca em defesa do leitor como um aspecto de forte apelo cidadão:

O Ombudsman representa, no jornal, a visão do leitor que, com uma visão externa à do jornalista, pode enriquecer a produção do jornal fazendo críticas construtivas e sugestões de melhoria.(...) Acompanhar esta coluna trará um hábito de leitura crítica em relação tanto a este jornal como às outras mídias, o que é uma prática fundamental para um cidadão que pretende se informar através desses meios, preparando-se melhor para entender a sociedade.

2. Os conceitos de cidadania aparecem na intenção de produção de uma informação que pretende ser clara, profunda e bem apurada.

A aluna Lígia Carriel, ao analisar seu trabalho na edição 284 do J C, ilustra bem a questão:

Eu acho que o jornalismo tem uma função de cidadania que é muito importante. Essa matéria tenta mostra isso. Eu queria era propor um debate, acho que o jornalista não faz nada sozinho e eu tinha que lançar esta questão polêmica, que eu tenho que mostrar lados dessa questão. Mas o que eles pensam? O que é o espaço público? Eu queria que as pessoas pensassem nisso. O que é uma universidade? O que faz uma representação estudantil dentro dessa uma universidade? Começar a repensar isso, foi o que eu tentei transpor na matéria. Não é só uma notícia, tem um debate por trás disso e eu preciso cutucar. Eu quero mexer e quero que as pessoas parem, pensem e discutam. 
3. Os conceitos de cidadania têm aparecido na didática e na relação que o docente estabelece com o discente, baseado no estímulo à autonomia individual, ao espírito de grupo e na delegação de responsabilidades e conseqüências.

As observações do professor Coelho ${ }^{38}$ sobre o texto de autoria do aluno André Benevides publicado na seção In Loco do J 282 com o título No muro, a arte da manifestação representa bem esse espírito:

Não fiz comentários no seu texto porque acredito que o sentido do In Loco é esse que você desenvolve. Entretanto, permito-me fazer alguns comentários à margem do seu texto para que você, os repórteres e editores do $\mathrm{J} C$ reflitam a respeito:

1. Se eu não estiver enganado na minha avaliação, parece que você entende como natural que as pichações sejam feitas nos muros DEMOCRÁTI COS (GRIFO NOSSO) da universidade. As pichações, creio, são um ataque ao PATRIMÔNIO PÚBLICO (GRIFO NOSSO) e isso fere uma das bandeira do JC que é a defesa do patrimônio da USP (físico e intelectual). Portanto, temos que pensar o que é mais importante: o uso das paredes para manifestações ou a defesa do patrimônio da universidade.

2. Outra contestação que pode ser feita é quanto ao CARÁTER DEMOCRÁTICO (GRIFO NOSSO) das pichações contra gays, judeus, palestinos ou negros. Evidentemente não diríamos que tais mensagens são democráticas. E isso aconteceria porque o caráter democrático das pichações estariam sobrepujando o caráter democrático do espaço. Veja você que uma pichação existente no teatro, que insinua que o jornalismo é uma manifestação nazista, não mereceu sua atenção. Foi por falta de conhecimento ou foi porque, na sua avaliação, essa mensagem não tem conteúdo para ilustrar a sua matéria?

3. Finalmente, em vista da ausência de uma intenção mais nítida da sua matéria, creio que você não esteve à vontade para fazêla ou, pelo menos, para defender um ponto de vista, já que ela (intenção) não está TÃo CLARA QUANTO SE ESPERA DE UMA MATÉRIA JORNALÍ STI CA (GRI FO NOSSO).

\footnotetext{
${ }^{38}$ Estas observações, muitas vezes iniciadas ou retomadas em sala de aula, constam de e-mails trocados entre o professor e a turma durante o processo de edição dos jornais.
} 


\section{CAPÍTULO VI}

\section{Dos Docentes}

\section{(...) o jornalista, como mediador social jamais pode esquecer a noção de cidadania para si, para o receptor para todos os atores envolvidos no processo da notícia.}

Patrícia Patrício, professora da ECA, em resposta a um dos itens do questionário de pesquisa

O cenário de fortes agitações políticas dos anos 60 e 70 que lhe serviu de berço, vai permear quase sempre a atuação dos professores da casa Escola de Comunicações e Artes da USP. A ECA teve vários de seus docentes cassados pelo regime militar a partir de 1969, como foi o caso do jornalista e professor Vladmir Herzog, o Vlado, morto em outubro de 1975, alguns meses depois de ter sido contratado como docente da escola.

Para ilustrar o quadro de pressões sofridas pelos professores da época, nos valemos de uma nota do professor Marques de Melo sobre o início de sua docência na escola e a retomada de suas atividades ${ }^{39}$ :

A maior dificuldade encontrada foi a conciliação impossível do ambiente autoritário peculiar no Brasil pós-68 e as condições indispensáveis de liberdade para a criação e a pesquisa de novas formas de expressão jornalística. Por não transigir com os mecanismos de repressão e de censura instituídos pelo regime militar, sofria a violência da engrenagem punitiva instaurada na USP, sendo afastado da cátedra e da pesquisa em 1974.

A anistia política de 1979 e a solidariedade de colegas que não perderam a dignidade naqueles anos sombrios restituíram-me a função docente e permitiram a retomada de um projeto acadêmico interrompido. Com o mesmo entusiasmo de antes, aceitei a convocação da comunidade do meu departamento para reconstituir as

\footnotetext{
${ }^{39}$ USP: ECA. Balanço de uma Gestão ECA - USP 1989-1992.
} 
estruturas didáticas precocemente envelhecidas e restaurar um ambiente intelectual propício ao desenvolvimento científico.

Não é só no seu início que a história da docência de Jornalismo na ECA imbrica-se com as questões nacionais. Até hoje o pensamento jornalístico ecano mistura-se com a história e as lutas do Brasil e do jornalismo brasileiro. A influência dos pensadores uspianos na conduta profissional de muitos jornalistas egressos da escola e, de resto, nas práticas jornalísticas do País, são eloqüentes.

No editorial da segunda edição da Revista do Pensamento Jornalístico Brasileiro, ao referir-se à primeira geração de pensadores uspianos (1967-1971), a professora Ruth Vianna (2003) observa:

(...) Flávio Galvão, José Freitas Nobre; Francisco Morel; Gaudêncio Torquato; Thomas Farkas; Juarez Bahia; Antonio Costella; Gileno Marcelino; Hélcio Deslandes; Alfredo Weissflog e Cremilda Medina vieram dar um colorido diferente para o Curso recém-criado, não só pelo dinamismo, criatividade, mas também pelo profissionalismo destes professores que sempre estiveram à frente de seu tempo, marcando profundamente este período cheio de contradições políticas, culturais em que a Nação brasileira se viu mergulhada com o início da ditadura no País, mas que nem por isso deixou de ser um momento mágico e rico em estudos, pesquisas e contribuições que são as bases dos estudos de jornalismo que vivemos até hoje, sem deixar de ser modernos (...).

Embora venha passando por modificações, a pós-graduação stricto sensu em Ciências da Comunicação / Área de Concentração Jornalismo, conseguiu marcar entre as suas linhas de pesquisa duas que merecem especial menção por suas preocupações com os estudos acadêmicos da formação e do compromisso cidadão do jornalista: Jornalismo Comparado e J ornalismo e Cidadania.

Sob responsabilidade do professor José Coelho Sobrinho, livredocente pela USP (2001) com a tese Do que somos capazes?: Relato de uma experiência pedagógica, o Núcleo de Jornalismo Comparado tem por objetivo:

(...) reunir docentes que desenvolvem estudos e pesquisas tendo o método comparativo como procedimento principal para o 
entendimento do fenômeno jornalístico. Está estruturado para atender aos alunos de pós-graduação em nível de doutorado e mestrado, bem como orientar alunos de graduação em iniciação científica e tutorado acadêmico. Faz a interface entre o terceiro grau e estudos acadêmicos avançados unindo esforços de pesquisadores de todos os níveis ${ }^{40}$.

Já o Núcleo de Jornalismo e Cidadania tem como responsável a professora Alice Mitika Koshiyama. Livre-docente pela USP (1993) com a tese Histórias do Jornalismo: das práticas jornalísticas às práticas pedagógicas, o núcleo objetiva:

(...) desenvolver atividades de ensino, pesquisa e práticas voltadas para a construção da cidadania, partindo do campo comum a todos: o estudo da comunicação e do jornalismo. As divergências de perspectivas teóricas e metodológicas estão explicitadas na organização e desenvolvimento dos projetos de pesquisa dos docentes. As diferenças constituem um dos fatores positivos para a compreensão da questão da cidadania e da comunicação hoje, permitindo uma integração entre o trabalho acadêmico e as atividades de extensão à comunidade. Espera-se que o conjunto de atividades do Núcleo permita equacionar as relações entre jornalismo e cidadania, enquanto fenômenos historicamente vinculados aos processos de organização da sociedade ${ }^{41}$.

\footnotetext{
${ }^{40}$ ECA: USP. Núcleos de Pesquisa. Disponível em: http://www.eca.usp.br/pesquisa/nuclpesq/nucleo.htm\#cie.

${ }^{41}$ ECA: USP. Núcleos de Pesquisa. Disponível em: http://www.eca.usp.br/pesquisa/nuclpesq/nucleo.htm\#cje.
} 


\subsection{Da Apresentação e da Análise dos Dados da Pesquisa}

Utilizando a técnica da entrevista partimos para a terceira fase do trabalho: a pesquisa com os docentes. Entre os professores, entrevistamos aqueles cujas disciplinas incluem conteúdo relacionado ao tema deste trabalho e também os docentes das áreas laboratoriais de jornalismo impresso ${ }^{42}$.

O objetivo nesta fase da pesquisa foi entender como a cidadania e seus temas correlatos: os direitos humanos, a democracia, a ética profissional e a responsabilidade social do jornalismo são trabalhados sob o ponto de vista dos professores em suas disciplinas, no conjunto do currículo do curso de Jornalismo noturno e nos projetos experimentais. Este critério foi mencionado para os docentes em carta (anexo 10) que fizemos acompanhar os questionários da pesquisa (anexo 11).

Pela amostra as entrevistas deveriam ser realizadas com docentes das disciplinas:

$\checkmark$ Legislação e Deontologia do J ornalismo;

$\checkmark$ Fundamentos Teóricos da História;

$\checkmark$ Pensamento Filosófico;

$\checkmark$ J ornalismo no Rádio e na TV;

$\checkmark$ História das Doutrinas Políticas;

$\checkmark$ Ética;

$\checkmark$ Laboratório de Iniciação ao J ornalismo;

$\checkmark$ Sociologia da Era Virtual;

$\checkmark$ História do Jornalismo I (Geral);

$\checkmark$ Fundamentos da Economia;

$\checkmark$ História do Jornalismo II (Brasil).

\footnotetext{
${ }^{42} \mathrm{~A}$ opção pelas disciplinas laboratoriais que trabalham com o jornalismo impresso se deve ao fato de que, a exemplo do que ocorre na maior parte dos cursos de Jornalismo do País, a formação técnica da ECA enfatiza esta área.
} 
Além destes, também seriam entrevistados os docentes das seguintes disciplinas laboratoriais:

$\checkmark$ Laboratório em Jornalismo I mpresso I;

$\checkmark$ Laboratório em Jornalismo Impresso II;

$\checkmark$ Laboratório em Jornalismo Impresso III;

$\checkmark$ Laboratório em Jornalismo Impresso - Revista ${ }^{\mathbf{4 3}}$.

A intenção inicial foi aplicar 13 (treze) questionários aos professores responsáveis pelas 15 (quinze) disciplinas da amostra no primeiro semestre de 2004. No entanto, apenas 9 (nove) professores de 9 (nove) disciplinas puderam responder / respondem ao material. Portanto, esta análise considera apenas estes últimos.

Dos 9 (nove) professores, 1 (um) é mestre, 5 (cinco) são doutores e 3 (três) têm pós-doutorado. Desse total, 4 (quatro) lecionam no ensino superior num período entre cinco e dez anos, 2 (dois) entre dez e vinte, 2 (dois) há mais de vinte anos e 1 (um) há menos de cinco anos.

A pesquisa constatou também que 4 (quatro) deles lecionam na ECA há um período que vai de um a cinco anos, 3 (três) entre cinco e dez e dois (2) há mais de vinte anos; 3 (três) deles ensinam também em outra graduação e afirmam que suas disciplinas lecionadas nos outros cursos, relação com a cidadania. A pesquisa mostra também que 7 (sete) lecionam na pós-graduação da ECA e, mais uma vez, afirmam que suas disciplinas têm relação com a cidadania.

Dos 9 (nove) docentes, apenas 1 (um) não tem experiência no mercado de trabalho profissional de comunicação. Entre os 8 (oito) restantes, 2 (dois) têm experiência entre cinco e dez anos, 3 (três) entre dez e vinte e 3 (três) aturaram / atuam há mais de vinte anos no mercado. Em todos os casos, os professores afirmam que a experiência fora de sala de aula agrega valores de cidadania ao trabalho docente.

\footnotetext{
${ }^{43} \mathrm{O}$ quadro com as ementas destas disciplinas se encontra no capítulo IV.
} 
Em relação ao perfil dos docentes, constatamos que dos 9 (nove) professores, 7 (sete) participaram de projetos em que a cidadania tinha um valor relevante durante a sua graduação e na última pós-graduação. Do grupo, 8 (oito) participam de projetos de extensão universitária, e em 7 (sete) desses casos a cidadania tem um valor relevante.

Para 3 (três) dos 9 (nove) professores pesquisados, a cidadania ocupa um valor 8 (oito), numa escala de 0 (zero) a 10 (dez) na disciplina que lecionam na ECA. Dois (2) deles atribuem um valor 9 (nove) e outros 2 (dois), atribuem 10 (dez). Do grupo, 1 (um) deles atribui valor 6 (seis) e 1 (um) outro docente, atribui valor 4 (quatro).

Oito (8) desses professores destacam que o conteúdo cidadão é trabalhado em sala de aula em atividades de caráter teórico e prático. Desses, 5 (cinco) acreditam que a cidadania é estimulada também na relação que procuram estabelecer com os estudantes. Além disso, 4 (quatro) entendem que ela é estimulada na relação que permitem / estimulam que o discente estabeleça com a disciplina, 5 (cinco) percebem-na na relação que permitem / estimulam que o discente estabeleça com a sua formação e 6 (seis) apontam-na na relação que permitem / estimulam que o discente estabeleça com a sua produção.

O quadro a seguir apresenta um breve perfil de cada docente, a sua avaliação sobre a presença da cidadania na disciplina da amostra, no conjunto das disciplinas que leciona no curso de Jornalismo da ECA, no currículo e nos projetos experimentais. 


\begin{tabular}{|c|c|c|c|}
\hline \multirow[b]{2}{*}{ Docente e disciplina ${ }^{44}$} & \multicolumn{3}{|c|}{ Avaliação do docente da relação entre a cidadania e: } \\
\hline & $\begin{array}{l}\text { Disciplina da amostragem e demais } \\
\text { disciplinas lecionadas no curso }\end{array}$ & Atual currículo & \begin{tabular}{|l|} 
Projetos \\
experimentais
\end{tabular} \\
\hline $\begin{array}{l}\text { Patrícia Patrício (substituta): } \\
\text { Graduada em J ornalismo, mestre, } \\
\text { doutoranda em Ciências da } \\
\text { Comunicação pela ECA. Leciona há } \\
\text { menos de cinco anos no ensino } \\
\text { superior e tem de dez a cinco anos de } \\
\text { experiência profissional no mercado de } \\
\text { trabalho. Tanto na graduação em } \\
\text { Jornalismo quanto na pós e em } \\
\text { trabalhos atuais de extensão trabalha } \\
\text { com temas relacionados à cidadania. } \\
\text { Disciplina: Legislação e Deontologia do } \\
\text { Jornalismo }\end{array}$ & $\begin{array}{l}\text { Numa escala de } 0 \text { (zero) a } 10 \text { (dez), a docente } \\
\text { atribui um valor } 10 \text { (dez) à contemplação da } \\
\text { cidadania na disciplina Legislação e Deontologia } \\
\text { do J ornalismo. "A deontologia, ou o conjunto } \\
\text { das normas que visam a preservar a ética } \\
\text { profissional, está profundamente ligada aos } \\
\text { conteúdos temáticos da cidadania. Segundo } \\
\text { Cláudio Abramo, a ética do jornalista é igual à } \\
\text { ética do marceneiro, do cidadão. Francisco } \\
\text { Karam, em sua tese de doutorado defendida na } \\
\text { ECA-USP, defende uma especificidade ética do } \\
\text { jornalismo". }\end{array}$ & $\begin{array}{l}\text { Nesse ponto, a docente atribui } \\
\text { nota } 7 \text { (sete) e faz sua } \\
\text { avaliação tomando como } \\
\text { referência o currículo da ECA } \\
\text { durante a sua graduação } \\
\text { (1991-1994). }\end{array}$ & $\begin{array}{l}\text { A docente afirmou } \\
\text { que não tem } \\
\text { condições para } \\
\text { avaliar esta questão. }\end{array}$ \\
\hline $\begin{array}{l}\text { Rosana de Lima Soares: Doutora, } \\
\text { graduada em Jornalismo e em } \\
\text { Filosofia. Leciona há menos de cinco } \\
\text { anos no ensino superior e tem entre } \\
\text { cinco e dez anos de experiência } \\
\text { profissional no mercado de trabalho. } \\
\text { Tanto na graduação em jornalismo } \\
\text { quanto na pós e em trabalhos atuais } \\
\text { de extensão trabalha com temas } \\
\text { relacionados à cidadania. } \\
\text { Disciplina: Pensamento Filosófico }\end{array}$ & $\begin{array}{l}\text { Na escala proposta, a docente atribui um valor } \\
9 \text { (nove) à contemplação da cidadania na } \\
\text { disciplina Pensamento Filosófico. "Ao tratar, } \\
\text { fundamentalmente, do humano no mundo que o } \\
\text { cerca, a filosofia revela e questiona modos de } \\
\text { vida, pontos de vista e perspectivas. Exige, } \\
\text { portanto, questionamento e reflexão constante } \\
\text { em relação à cidadania em sentido amplo". } \\
\text { No conjunto das disciplinas lecionadas na ECA a } \\
\text { docente também atribui um valor } 9 \text { (nove): } \\
\text { “Além da disciplina Pensamento Filosófico } \\
\text { ministro disciplinas optativas que relacionam } \\
\text { diretamente as produções das mídias e a } \\
\text { cidadania por tematizarem problemas sociais, } \\
\text { questões éticas e políticas. }\end{array}$ & $\begin{array}{l}\text { Nota } 9 \text { (nove) para o currículo } \\
\text { do curso: "O curso da ECA } \\
\text { não possui viés tecnicista, } \\
\text { priorizando uma formação } \\
\text { humanística (não apenas nas } \\
\text { disciplinas teóricas mas } \\
\text { também nas práticas } \\
\text { laboratoriais). Ao discutir } \\
\text { conteúdos de filosofia, } \\
\text { história, ética, política, } \\
\text { estimula a reflexão e o } \\
\text { posicionamento em relação à } \\
\text { sociedade como um todo e ao } \\
\text { papel do jornalismo". }\end{array}$ & $\begin{array}{l}\text { Nota } 9 \text { (nove) para a } \\
\text { cidadania nos TCCs: } \\
\text { "Por seu perfil crítico, } \\
\text { os alunos realizam } \\
\text { trabalhos que } \\
\text { tematizam o } \\
\text { jornalismo e as } \\
\text { mídias nos seus } \\
\text { aspectos técnicos, } \\
\text { narrativos, estéticos, } \\
\text { tecnológicos e, ao } \\
\text { fazê- lo, destacam a } \\
\text { função do jornalismo } \\
\text { e sua } \\
\text { responsabilidade". }\end{array}$ \\
\hline
\end{tabular}

${ }^{44}$ Aqui não consideramos a disciplina Projetos Experimentais em J ornalismo por não haver uma configuração de aula convencional. A disciplina funciona com professores-orientadores escolhidos pelos alunos de acordo com o tema do trabalho. 


\begin{tabular}{|c|c|c|c|}
\hline $\begin{array}{l}\text { Dennis de Oliveira: Doutor, graduado } \\
\text { em J ornalismo. Tem de dez a vinte } \\
\text { anos de experiência no ensino superior } \\
\text { e mais de vinte de experiência } \\
\text { profissional no mercado de trabalho. } \\
\text { Tanto na graduação em Jornalismo } \\
\text { quanto na pós e em trabalhos atuais } \\
\text { de extensão trabalha com a cidadania } \\
\text { ou temas correlatos. } \\
\text { Disciplina: Laboratório de } \\
\text { Iniciação ao Jornalismo }\end{array}$ & $\begin{array}{l}\text { Na escala proposta o docente atribui um valor } 9 \\
\text { (nove) à contemplação da cidadania na } \\
\text { disciplina Laboratório de Iniciação ao } \\
\text { Jornalismo: "Trabalho com uma comunidade e } \\
\text { tem características de um projeto de extensão". } \\
\text { Sem comentários, o docente atribui um valor } 7 \\
\text { (sete) ao conjunto das disciplinas que leciona } \\
\text { na graduação ecana. }\end{array}$ & $\begin{array}{l}\text { O docente atribui a este ponto } \\
\text { nota } 4 \text { (quatro): "O curso tem } \\
\text { um viés muito voltado para a } \\
\text { grande mídia". }\end{array}$ & $\begin{array}{l}\text { Por ainda não haver } \\
\text { participado } \\
\text { ativamente dos } \\
\text { projetos } \\
\text { experimentais da } \\
\text { ECA, o docente } \\
\text { afirma não ter } \\
\text { condições de avaliar } \\
\text { a questão. }\end{array}$ \\
\hline $\begin{array}{l}\text { Mayra Rodrigues Gomes: Pós- } \\
\text { doutora, tem de cinco a dez anos no } \\
\text { ensino superior na ECA. Não possui } \\
\text { experiência profissional no mercado de } \\
\text { trabalho. Na graduação e na pós- } \\
\text { graduação trabalhou com temas } \\
\text { relacionados à cidadania. Hoje, nos } \\
\text { trabalhos de extensão, a cidadania não } \\
\text { aparece como um elemento relevante. } \\
\text { Disciplina: Ética }\end{array}$ & $\begin{array}{l}\text { Nos valores indicados na escala a docente } \\
\text { atribui um valor } 8 \text { (oito) à contemplação da } \\
\text { cidadania na disciplina Ética. "As questões } \\
\text { éticas se cruzam necessariamente com os } \\
\text { valores do nosso tempo, com os ideais e } \\
\text { direitos humanos etc". } \\
\text { Ao conjunto das demais disciplinas lecionadas a } \\
\text { docente atribui valor } 8 \text { (oito). "Embora o foco } \\
\text { das minhas disciplinas não seja a questão da } \\
\text { cidadania, todas elas a têm como pano de } \\
\text { fundo". }\end{array}$ & $\begin{array}{l}\text { A docente afirma não ter } \\
\text { condições de avaliar este } \\
\text { item: "Não estou a par do } \\
\text { estatuto da cidadania para as } \\
\text { outras disciplinas que } \\
\text { compõem o curso". }\end{array}$ & $\begin{array}{l}\text { Em relação à } \\
\text { presença da } \\
\text { cidadania nos TCCs, } \\
\text { atribui valor } 10 \\
\text { (dez): "As questões } \\
\text { do desenvolvimento } \\
\text { de programas } \\
\text { sociais, investidos em } \\
\text { ações afirmativas } \\
\text { etc. têm sido objeto } \\
\text { de reflexão". } \\
\end{array}$ \\
\hline $\begin{array}{l}\text { Eun Yung Park: Doutora graduada } \\
\text { em Jornalismo e em Administração, } \\
\text { tem de cinco a dez anos no ensino } \\
\text { superior. Tem de dez a vinte anos de } \\
\text { experiência no mercado de trabalho. } \\
\text { Tanto nas graduações quanto na pós e } \\
\text { em trabalhos de extensão trabalha } \\
\text { com temas relacionados à cidadania. } \\
\text { Disciplina: Fundamentos da Economia }\end{array}$ & $\begin{array}{l}\text { Em relação à disciplina da amostra, a docente } \\
\text { atribui nota } 8 \text { (oito): “A disciplina que leciono é } \\
\text { 'Fundamentos de Economia'. Nas aulas, tento } \\
\text { passar os conceitos de maneira que os alunos } \\
\text { compreendam que o conhecimento sobre } \\
\text { economia ajudará a eles próprios e a sociedade } \\
\text { em geral a praticar a cidadania e a tornar a } \\
\text { democracia mais possível”. } \\
\text { Em relação ao conjunto das demais disciplinas, } \\
\text { a docente reforça a nota } 8 \text { (oito) e remete à } \\
\text { justificativa anterior. }\end{array}$ & $\begin{array}{l}\text { Para a docente, é difícil } \\
\text { atribuir um valor a esta } \\
\text { questão: “O conceito de } \\
\text { cidadania é muito amplo e é } \\
\text { difícil falar em que grau de } \\
\text { importância ele é colocado no } \\
\text { atual currículo. Acredito que } \\
\text { todos os docentes têm a } \\
\text { preocupação em formar } \\
\text { cidadãos preocupados com } \\
\text { uma sociedade mais justa". }\end{array}$ & $\begin{array}{l}\text { “È difícil avaliar, uma } \\
\text { vez que não conheço } \\
\text { os trabalhos", } \\
\text { observa a docente. }\end{array}$ \\
\hline
\end{tabular}


José Luís Proença: Doutor, graduado em Jornalismo, está há mais de vinte anos no ensino superior da ECA. Tem também experiência de mais de vinte anos no mercado de trabalho de comunicação. Tanto na graduação quanto na pós e nos trabalhos de extensão que vem realizando a cidadania aparece como um tema recorrente.

Disciplina: Laboratório em Jornalismo Impresso I

J osé Coelho Sobrinho: Pós- doutor, graduado em Jornalismo pela ECA, está há mais de vinte anos no ensino superior da ECA. Tem também experiência de mais de vinte anos no mercado de trabalho de comunicação. Nem na graduação nem na pós esteve envolvido com o estudo da cidadania.

Hoje, nos trabalhos que vem realizando em nível de extensão a cidadania aparece como um tema relevante.

Disciplina: Laboratório em Jornalismo Impresso II
Para o professor, o valor da disciplina

Laboratório em Jornalismo Impresso I na escala proposta é seis (6). No entanto, ele ressalva:

“Considerando apenas a idéia de cidadania. O restante das preocupações fica restrito ao processo de formação acadêmica, mais especificamente para a crítica do material produzido pelo grupo de discentes".

No restante das disciplinas sob sua

responsabilidade, o docente atribui valor 8 ( oito). "Todo o processo de estilo, edição e distribuição das informações são analisados sob o prisma da prática e exercício da cidadania, sempre considerando que o jornalista é o responsável pela abertura das diversas vozes no espaço público".

Numa escala de 0 (zero) a 10 (dez), o docente atribui um valor 4 (quatro) à contemplação da cidadania na disciplina Laboratório em J ornalismo Impresso II. "Falta clareza nos objetivos das disciplinas cujos conteúdos têm ou deveriam ter ênfase no desenvolvimento desse conceito".

Também no conjunto das disciplinas que leciona na ECA, o docente repete a atribuição 4

(quatro). "Nem todos os tópicos do programa possibilitam a discussão do conceito".
No atual currículo do curso de Jornalismo, o professor atribui à cidadania valor 7 (sete): “Em razão do processo de aprendizagem, tanto dos processo acadêmicos como da formação profissional".

"Pelos motivos já expostos", o professor, atribui o valor 4 (quatro) à cidadania no currículo do jornalista ecano.
Neste ponto, valor 8 (oito): "É difícil entender uma monografia tipo TCC que não aborde temas afins à cidadania".

Nos TCCs, o professor atribui valor 7 (sete) à presença da cidadania: "Observase que os alunos de TCCs dão importância ao conceito". 
Nancy N. Ramadan: Doutora,

graduada em Jornalismo, tem de cinco a dez ano no ensino superior da ECA.

Tem entre dez e vinte anos de experiência no mercado de trabalho. Tanto na graduação quanto na pós esteve envolvida com a cidadania ou temas correlatos.

Disciplina: Laboratório em J ornalismo Impresso III

Cláudio Tognolli: Pós-doutor, graduado em J ornalismo, tem de dez a vinte anos de ensino superior. Tem também experiência de mais de vinte anos no mercado de trabalho de comunicação. Na graduação e na pós esteve envolvido com o estudo da cidadania. Nos trabalhos que vem realizando em nível de extensão a cidadania aparece como um tema relevante.

Disciplina: Laboratório em J ornalismo Impresso - Revista
Neste item a docente atribui valor 8 (oito) à contemplação da cidadania em Laboratório em J ornalismo Impresso III. "Não dá para pensar ensino de jornalismo sem cidadania. É de importância fundamental na formação de futuros jornalistas".

No conjunto de suas disciplinas, a professora entende que a cidadania tem um valor 8 (oito) reforçando os motivos citados anteriormente.

da cidadania na disciplina Laboratório em J ornalismo Impresso - Revista. "Minha atuação como jornalista sempre foi na área da cidadania e dos direitos humanos".

Reforçando os motivos acima, o docente estende o valor 10 (dez) à cidadania no conjunto das disciplinas que leciona.
Ao currículo, a professora atribui valor 10 (dez) em relação à cidadania. "Penso que o currículo contempla a cidadania, não sei se na prática, em sala, o currículo se aplica. Penando só no currículo, é dez".

0 docente estende $\mathrm{o}$ valor 10 (dez) à cidadania no currículo ecano.
Para a docente, os

TCCs apresentam um valor 9 (nove) em relação à cidadania. "Nos trabalhos que orientei e nas bancas de que participei o tema está sempre presente, de uma forma direta ou não. São raros os

trabalhos que deixam o tema totalmente esquecido".

\section{Reforçando os} motivos anteriores, 0 docente atribui 0 valor 10 (dez) à presença da cidadania nos TCCs. 
Paralelamente a esta parte da pesquisa, dois momentos singulares que nos auxiliaram na compreensão do papel do docente na formação cidadã do jornalista ecano foram a coluna de ombudsman do Jornal do Campus e a relação estabelecida pelo docente José Coelho Sobrinho com os alunos da disciplina Laboratório em Jornalismo Impresso II durante a produção do jornal, este último, conforme comentamos no capítulo anterior.

Nas edições 282 a 286, a professora do Núcleo de Jornalismo e Linguagem do Departamento de Jornalismo e Editoração da ECA, Rosana de Lima Soares, participou como ombudsman do JC.

Nos textos publicados pela professora nas cinco edições, a cidadania aparece como um tema recorrente. O jornalismo e a lógica dos conflitos (edição 282), ainda que discuta as relações conflituosas entre chamadas, títulos de capa, títulos internos e matérias, a professora chama atenção para uma discussão maior entre os conflitos de interesses na própria gênese da atividade jornalística:

É preciso deixar claro que não se trata de estabelecer uma crítica à
presença desses conflitos, como se o jornal não devesse espelhar as
contradições presentes no campus da USP. Mas não se pode
transformá-los em pseudoconflitos, nos quais haveria dois lados em
disputa - afinal, é a comunidade universitária como um todo que o
Jornal do Campus contempla, na defesa de seus interesses e na
reflexão sobre seus problemas e soluções.

Discutindo o caráter argumentativo dos textos publicados, Persuadir, convencer, demonstrar (edição 283) volta à temática da cidadania ao alertar para a responsabilidade social da informação jornalística:

Nos discursos jornalísticos, portanto, opinião e informação precisam andar juntas, ainda que em alguns momentos haja predominância de uma sobre outra. A argumentação deve almejar o equilíbrio e não apenas a eficácia da transmissão de pontos de vista ou dados. Quanto maior este equilíbrio, maiores as interseções estabelecidas entre o texto e o seu leitor. 
Estigmas, estereótipos, preconceitos: bifurcações (edição 284) procura despertar atenção para as minorias e o modo como elas são tratadas pelos jornais, que hora buscam uma atitude pautada no 'politicamente correto' e hora não conseguem escapar de um comportamento nada comprometido com a cidadania. Em alguns momentos o J C não consegue escapar desse lamentável entrave:

Ainda que colocado entre aspas, pergunto-me se ao destacar que 'A USP passa por uma hora negra ${ }^{45}$ não estaríamos, mais uma vez, explicitando as separações que colocam o jornalismo, muitas vezes, como mero reprodutor de estigmas sociais.

Jornalismo e referencialidade: números demais? (edição 285) discute uma questão bastante presente no jornalismo contemporâneo: a utilização de números, tabelas, referências numéricas e como instrumento auxiliar do discurso jornalístico. Segundo a professora, isso se deve à tentativa do jornal em criar, para o leitor, um efeito de realidade, plasmado por um ideal de cientificidade. No caso do JC, em alguns momentos, segundo a ombudsman, os números chegam a comprometer a exatidão da informação. É o que a professora observa claramente em títulos e trechos da cobertura da greve por reajuste de professores e funcionários publicados na edição anterior: “'Cruesp mantém a proposta de $0 \%$ '; reitores 'mantiveram sua posição de $0 \%$ de reajuste salarial'; reunião terminou 'sem que fosse oferecido um reajuste maior que $0 \%$ '". Segundo a professora:

Ao contrário da matemática, em seu jogo de ambigüidades a língua nos ensina uma lição: o que vimos até o momento nas negociações é a proposta de não haver aumento. O que nos leva a pensar que o jornalismo, muitas vezes, na ambição de se tornar mais e mais científico, torna-se mais e mais impreciso, afastando-se contraditoriamente - daquilo que almeja alcançar.

Em seu último texto, a ombudsman traz um outro tema recorrente nas discussões da linguagem jornalística: a fotografia. Em

\footnotetext{
${ }^{45} \mathrm{O}$ título citado refere-se à edição 283, abre a entrevista com o professor Paulo Vanzolini e é a transcrição de uma citação do próprio entrevistado.
} 
Redundâncias, ressonâncias (edição 286), apontando a fotografia como uma versão da realidade, a ombudsman questiona a qualidade do material publicado no JC, especialmente na edição 285. A autora propõe a substituição de um efeito de redundância em que fotos, junto com títulos e textos, formam um conjunto harmônico, pela busca de um efeito de ressonância. Neste último caso, a fotografia poderia estimular diferentes olhares e leituras polissêmicas. Nesse momento é tocado um ponto importante para a imprensa: a questão da imparcialidade jornalística. A polissemia e a dialética do processo de construção permanente da cidadania agradecem.

Enfim, considerando a atuação da ombudsman e do professor que esteve à frente do JC, os resultados da pesquisa com os docentes nos levam ao seguinte resultado em relação à habilitação em Jornalismo noturno da ECA / USP:

1. Os valores atribuídos pelos docentes - 10,0, 10,0, 9,0, $9,0,8,0,8,0,8,0,6,0$ e 4,0 - , resultando na média 9,0 (nove), apontam que, em média, os professores, entendem que a cidadania é contemplada em suas disciplinas.

A média mais alta [8,8 (oito e oito décimos)], vale ressaltar, é assinalada pelos professores dos primeiros semestres cujas disciplinas, como havíamos observado no capítulo IV, contemplam a cidadania mais claramente em suas ementas. Os professores das disciplinas laboratoriais apresentam média mais baixa [ 7,0 ( sete)];

2. A variação dos valores atribuídos pelos docentes em relação à contemplação da cidadania no conjunto do currículo 10,0, 10,0, 9,0, 7,0, 7,0, 4,0 e 4,0 [resultando na média 7,2 (sete e dois décimos)] - aponta que há discordância, entre os professores, em relação a este aspecto. 
Mas aqui não há, praticamente, uma diferenciação em relação aos professores das disciplinas dos primeiros semestres [com média 6,0 (seis)] e os das laboratoriais [média 7,7 (sete e sete décimos) ];

3. Os valores atribuídos pelos docentes à cidadania nos projetos experimentais $(10,0 \quad 10,0 \quad 9,0$ 9,0 8,0 e 7,0) dão ao quesito um valor 8,8 (oito e oito décimos), o que aponta que, para os docentes, a cidadania é efetivamente contemplada nos TCCs.

Neste item aparece uma pequena diferenciação em relação aos professores das disciplinas dos primeiros semestres [com média 9,5 (nove e meio)] e os das laboratoria is [média 8,5 (oito e meio)];

4. Os conceitos de cidadania aparecem na relação do docente com a sua compreensão do papel social do jornalismo e das demais práticas informativas;

5. Os conceitos de cidadania aparecem na intenção do ensino e da produção de uma informação crítica, pautada em valores morais e numa boa apuração. A professora Rosana de Lima Soares, ao avaliar o atual currículo ecano de Jornalismo ilustra bem a questão:

O curso da ECA não possui viés tecnicista, priorizando uma
formação humanista (não apenas nas disciplinas teóricas, mas
também nas práticas laboratoriais). Ao discutir conteúdos de
filosofia, história, ética, política, estimula a reflexão e o
posicionamento em relação à sociedade como um todo e ao papel do
jornalismo. 
6. Os conceitos de cidadania aparecem no modelo de relação que o professor busca estabelecer com o trabalho e com uma visão democrática de mundo;

7. Os conceitos de cidadania aparecem, como conseqüência dos itens acima, na relação do professor com o aluno na proposição de uma educação pautada na democracia e nos direitos humanos.

Ao chamar atenção para o texto que estava sendo elaborado pela aluna Paula Lima e que circulou no JC 282 com o título Redes em fio dão novos rumos às tecnologias de comunicação, o professor Coelho observou:

Você continua com uma linguagem técnica. A notícia, na verdade, está nos benefícios que os alunos e professores terão com o uso dessa nova tecnologia. Por exemplo: os alunos poderão acessar aulas por essa nova tecnologia; a burocracia será agilizada; os assentamentos escolares serão possíveis de consultar com mais facilidade; o sistema correrá menos riscos de cair etc. A tecnologia, em outras palavras, é o menos importante. O que deve ter mais importância para o leitor são os resultados de implementação dessa tecnologia. 


\title{
CAPÍTULO VII
}

\section{Dos Projetos Experimentais}

\begin{abstract}
“(..) a imagem das classes populares nos jornais se forma a partir de uma visão externa, baseada nos estigmas que lhes são atribuídos por aqueles que têm acesso produzir as informações. Partindo destes princípios, este trabalho se propõe a analisar os estigmas sociais das classes populares nos jornais paulistas Folha de S. Paulo e O Estado de S. Paulo, com o objetivo de pensar o papel do jornalismo na construção de uma sociedade democrática."
\end{abstract}

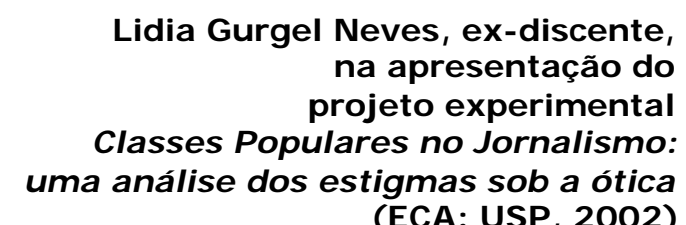

(ECA: USP, 2002)

No nono e último período do curso de Jornalismo, os alunos da ECA têm por obrigação a realização de um projeto experimental como condição para a obtenção do grau de bacharel na habilitação. A efetivação desse projeto, conhecido também como trabalho de conclusão de curso (TCC), dá-se na disciplina Projeto Experimental em Jornalismo (CJE-411), ofertada semestralmente com uma carga horária de 40 horas.

A disciplina, que trabalha com projetos ou pesquisas nas áreas de jornalismo, tem como objetivo "dar ao aluno oportunidade para realizar trabalho de conclusão de curso, teórico ou prático, ligado ao seu campo de interesse de especialização, sob a orientação de professores, dentro de uma das áreas de pesquisa do Departamento”46.

\footnotetext{
${ }^{46}$ Ementa da disciplina.
} 
Nesta quarta e última fase da pesquisa levantamos o aparecimento da cidadania ou temas correlatos - democracia, direitos humanos, responsabilidade social e ética profissional do jornalismo - como assunto direta ou indiretamente abordado nos trabalhos de conclusão inclusive como forma de entender os resultados finais de uma formação que, conforme havíamos constatado no primeiro momento da pesquisa, concentra curricularmente esse conteúdo nos quatro primeiros semestres.

Ao todo, a Biblioteca da ECA disponibiliza para consulta um total 741 (setecentos e quarenta e um) trabalhos de conclusão de curso do Departamento de Jornalismo e Editoração ${ }^{47}$.

Como amostra para os nossos estudos selecionamos os trabalhos de conclusão de curso de Jornalismo noturno dos dois anos consecutivos constantes na biblioteca. Trabalhamos, assim, com os anos 2002 e 2003 porque até o fechamento desta fase da pesquisa (abril de 2005) poucos trabalhos referentes a 2004 haviam sido depositados. Além disso, nos ativemos ao curso noturno para seguir a mesma opção adotada em relação ao currículo, aos discentes e à produção laboratorial.

Desse período estavam cadastrados 55 (cinqüenta e cinco) trabalhos de Jornalismo noturno (apêndice 02):

\footnotetext{
${ }^{47}$ Estes dados foram informados pela bibliotecária da Biblioteca da ECA Olga Mendonça em abril de 2005.
} 


\section{Primeiro semestre de 2002 - Jornalismo Noturno}

\begin{tabular}{|c|c|c|}
\hline Discente & Título $^{48}$ & Palavras-chave \\
\hline $\begin{array}{l}\text { Adriana } \\
\text { Fernandes } \\
\text { Farias }\end{array}$ & $\begin{array}{l}\text { Reforma psiquiátrica no Brasil: } \\
\text { um caminho a percorrer }\end{array}$ & $\begin{array}{l}\text { Psiquiatria; doenças mentais; } \\
\text { hospitais psiquiátricos; Instituto } \\
\text { Cândido Ferreira. }\end{array}$ \\
\hline $\begin{array}{l}\text { Alethea } \\
\text { Rodrigues } \\
\text { Semenov }\end{array}$ & $\begin{array}{l}\text { Turismo ambiental no Pantanal } \\
\text { Norte: pelos caminhos da } \\
\text { Tanspantaneira }\end{array}$ & $\begin{array}{l}\text { Turismo ecológico; Mato Grosso; } \\
\text { turismo e meio ambiente. }\end{array}$ \\
\hline $\begin{array}{l}\text { Ana Carolina } \\
\text { Rocha Vaz }\end{array}$ & \begin{tabular}{|l|} 
Revistas de celebridades: \\
passaporte para o sonho
\end{tabular} & $\begin{array}{l}\text { Revistas brasileiras; análise de } \\
\text { conteúdo. }\end{array}$ \\
\hline $\begin{array}{l}\text { Ana Carolina } \\
\text { Saito }\end{array}$ & $\begin{array}{l}\text { Ensaio sobre a opinião pública } \\
\text { política: Kant segundo Hannah } \\
\text { Arendt }\end{array}$ & $\begin{array}{l}\text { Opinião pública; política; filosofia; } \\
\text { KANT, I mmanuel, 1724-1804; } \\
\text { ARENDT; Hannah, 1906-1975. }\end{array}$ \\
\hline $\begin{array}{l}\text { André S. de } \\
\text { Toledo Piza }\end{array}$ & Digitalização no cinema & Cinema; técnica digital. \\
\hline $\begin{array}{l}\text { Andréa L. } \\
\text { Leite }\end{array}$ & $\begin{array}{l}\text { O encantamento da serpente: } \\
\text { sensualidade na dança do ventre }\end{array}$ & Dança do ventre. \\
\hline $\begin{array}{l}\text { Arnaldo } \\
\text { Grizzo Filho }\end{array}$ & Sobre o Atlântico & $\begin{array}{l}\text { Aviação; Brasil; BARROS, João Ribeiro } \\
\text { de, 1900-1947. }\end{array}$ \\
\hline $\begin{array}{l}\text { Cassiano } \\
\text { Ricardo } \\
\text { Gobbet }\end{array}$ & $\begin{array}{l}\text { Por que a gente é assim: } \\
\text { Um passeio pela cultura que } \\
\text { tempera o futebol }\end{array}$ & Futebol; Brasil. \\
\hline $\begin{array}{l}\text { Cely da Silva } \\
\text { Carmo }\end{array}$ & $\begin{array}{l}\text { Edição no } 0 \text { (zero) da série } \\
\text { "Grandes Mestres da Ciência } \\
\text { Brasileira": André Dreyfus } \\
\text { (genética animal e humana) }\end{array}$ & $\begin{array}{l}\text { Ciência - Brasil; Revistas científicas - } \\
\text { Brasil. DREYFUS, André, 1897-1952. }\end{array}$ \\
\hline $\begin{array}{l}\text { Daniele P. } \\
\text { Ricieri }\end{array}$ & $\begin{array}{l}\text { A crítica teatral e sua inserção } \\
\text { na indústria cultural }\end{array}$ & Crítica teatral; Brasil; Século XX. \\
\hline $\begin{array}{l}\text { Joana M. } \\
\text { Matushita }\end{array}$ & $\begin{array}{l}\text { Passagens: a história de Ney } \\
\text { Bourroul }\end{array}$ & $\begin{array}{l}\text { Deficientes me ntais; Síndrome de } \\
\text { Down; BOURROUL, Ney. }\end{array}$ \\
\hline $\begin{array}{l}\text { Marina M. } \\
\text { Gonçalves } \\
\text { Vieira }\end{array}$ & A vida no arame & Circo; Brasil. \\
\hline $\begin{array}{l}\text { Rafael F. } \\
\text { Garcia }\end{array}$ & $\begin{array}{l}\text { A universidade no caminho da } \\
\text { exclusão social }\end{array}$ & Universidades; Educação; Brasil. \\
\hline
\end{tabular}

\footnotetext{
${ }^{48}$ Os títulos, palavras-chave e resumos foram transcritos com base na forma como foram disponibilizados pelos alunos em seus trabalhos ou como constavam nos cadastros digitais da biblioteca da ECA. Em alguns momentos, por questões metodológicas ou de espaço, fizemos uma ou outra alteração.
} 


\section{Segundo semestre de 2002 - J ornalismo Noturno}

\begin{tabular}{|c|c|c|}
\hline Discente & Título & Palavras-chave \\
\hline $\begin{array}{l}\text { Aduil Roberto } \\
\text { Silva J únior }\end{array}$ & $\begin{array}{l}\text { Revolução Constitucionalista de } \\
\text { 32: a Guerra de São Paulo }\end{array}$ & $\begin{array}{l}\text { Getúlio Vargas; História de São Paulo; } \\
\text { Revoluções; Revolução } \\
\text { Constitucionalista de } 32 .\end{array}$ \\
\hline $\begin{array}{l}\text { Ângela R. } \\
\text { Nunes }\end{array}$ & $\begin{array}{l}\text { São Paulo Verso e Reverso: } \\
\text { o Fascínio do Centro Histórico }\end{array}$ & $\begin{array}{l}\text { Centro de São Paulo; revitalização do } \\
\text { Centro; fotografia. }\end{array}$ \\
\hline $\begin{array}{l}\text { Carolina } \\
\text { Fantaccini } \\
\text { Brito }\end{array}$ & $\begin{array}{l}\text { Literatura Feminina: Retratos do } \\
\text { Imaginário }\end{array}$ & $\begin{array}{l}\text { Imaginário; feminino; literatura; } \\
\text { ficção; contextualização de época; } \\
\text { contraste. }\end{array}$ \\
\hline $\begin{array}{l}\text { Daniel } \\
\text { Loneeff }\end{array}$ & $\begin{array}{l}\text { Ensaio Reportagem: } \\
\text { A Revolução Silenciosa }\end{array}$ & $\begin{array}{l}\text { Administração e tecnologia; } \\
\text { Tecnologia da informação; Gestão da } \\
\text { informação; Administração de } \\
\text { empresas. }\end{array}$ \\
\hline $\begin{array}{l}\text { Larissa } \\
\text { Purvinis } \\
\text { Musolino }\end{array}$ & $\begin{array}{l}\text { Fuzilado na Barão de Limeira: } \\
\text { depoimentos de jornalistas que } \\
\text { testemunharam vida e morte do } \\
\text { Notícias Populares }\end{array}$ & $\begin{array}{l}\text { Imprensa; imprensa popular; } \\
\text { jornalismo popular; sensacionalismo; } \\
\text { Notícias } \\
\text { Populares; grupo Folha; História oral. }\end{array}$ \\
\hline $\begin{array}{l}\text { Laura M. } \\
\text { Giannecchi- } \\
\text { ni }\end{array}$ & Revista Dois Pontos & $\begin{array}{l}\text { Dois pontos; energia elétrica; } \\
\text { problemas sociais; revista. }\end{array}$ \\
\hline $\begin{array}{l}\text { Lidia Gurgel } \\
\text { Neves }\end{array}$ & $\begin{array}{l}\text { Classes Populares no } \\
\text { Jornalismo: Uma análise dos } \\
\text { estigmas sob a ótica }\end{array}$ & $\begin{array}{l}\text { Estigma; esfera pública; classes } \\
\text { populares; povo; jornalismo; mídia. }\end{array}$ \\
\hline $\begin{array}{l}\text { Márcio } \\
\text { Kameoka }\end{array}$ & $\begin{array}{l}\text { Fome no Brasil: Caminhos } \\
\text { trilhados e a distância por } \\
\text { percorrer }\end{array}$ & $\begin{array}{l}\text { Reportagem; fome; desnutrição; } \\
\text { políticas públicas; políticas sociais; } \\
\text { história. }\end{array}$ \\
\hline $\begin{array}{l}\text { Márcio } \\
\text { Tucunduva } \\
\text { de Faria }\end{array}$ & $\begin{array}{l}\text { Adolescência Positiva: } \\
\text { Documentário sobre } \\
\text { adolescentes HIV - positivos de } \\
\text { transmissão vertical. }\end{array}$ & $\begin{array}{l}\text { AIDS; HIV; Casa Vida; Padre Júlio } \\
\text { Lancelotti; transmissão vertical; } \\
\text { Hospital Emílio Ribas; adolescente; } \\
\text { adolescência; SIDA; Instituto de } \\
\text { Infectologia. }\end{array}$ \\
\hline $\begin{array}{l}\text { Nádia Barba } \\
\text { Chiqueta }\end{array}$ & Mulheres e Grades & $\begin{array}{l}\text { Mulheres delinqüentes; Brasil; } \\
\text { presidiários; prisões para mulheres. }\end{array}$ \\
\hline $\begin{array}{l}\text { Renato S. } \\
\text { Targa }\end{array}$ & $\begin{array}{l}\text { Gerencie seu estresse ou fique } \\
\text { doente }\end{array}$ & Estresse; Saúde. \\
\hline $\begin{array}{l}\text { Tomaz } \\
\text { Rodrigo } \\
\text { Alves }\end{array}$ & $\begin{array}{l}\text { Artilheiro É Quem Decide: } \\
\text { os goleadores mais importantes } \\
\text { das eliminatórias e da Copa do } \\
\text { Mundo } 2002\end{array}$ & $\begin{array}{l}\text { Copa do Mundo 2002; Eliminatórias } \\
\text { 2002; Artilheiros; Perfis; Futebol. }\end{array}$ \\
\hline
\end{tabular}




\section{Primeiro semestre de 2003 - J ornalismo Noturno}

\begin{tabular}{|c|c|c|}
\hline Discente & $\begin{array}{c}\text { Título } \\
\end{array}$ & \begin{tabular}{|c|} 
Palavras-chave \\
\end{tabular} \\
\hline $\begin{array}{l}\text { Ana Paula } \\
\text { Ziglio de } \\
\text { Andrade }\end{array}$ & $\begin{array}{l}\text { Somos Franceses: como vivem } \\
\text { os ciganos na França do século } \\
\text { XXI }\end{array}$ & $\begin{array}{l}\text { Ciganos; pessoas de viagem; } \\
\text { nômades; França. }\end{array}$ \\
\hline $\begin{array}{l}\text { Fabiana } \\
\text { Vezzali }\end{array}$ & $\begin{array}{l}\text { Do mesmo lado do balcão: as } \\
\text { relações entre jornalistas e } \\
\text { assessores de imprensa }\end{array}$ & $\begin{array}{l}\text { J ornalismo; assessoria de imprensa; } \\
\text { reportagem. }\end{array}$ \\
\hline $\begin{array}{l}\text { Gustavo } \\
\text { Schor }\end{array}$ & $\begin{array}{l}\text { A tenacidade de genes e sonhos: } \\
\text { os } 50 \text { anos do Hospital do } \\
\text { Câncer }\end{array}$ & $\begin{array}{l}\text { Reportagem; livro; câncer-hospital; } \\
\text { Associação Paulista de Combate; } \\
\text { Ludwig - Instituto de Pesquisa sobre } \\
\text { o Câncer; Genoma - Projeto. }\end{array}$ \\
\hline $\begin{array}{l}\text { Júlia Bruno } \\
\text { Moióli }\end{array}$ & Borges, o repórter imaginário & $\begin{array}{l}\text { Jornalismo; formas de reportar } \\
\text { diferenciadas; discurso midiático; } \\
\text { mídia e poética; literatura; literatura } \\
\text { latino- americana, cultura latino- } \\
\text { americana; Argentina das décadas de } \\
20 \text { e 30; imaginário social. }\end{array}$ \\
\hline $\begin{array}{l}\text { Laura de C. } \\
\text { Naime }\end{array}$ & São Paulo sobre trilhos & $\begin{array}{l}\text { Ferrovia; São Paulo (Estado); } \\
\text { imigração; café; povoamento. }\end{array}$ \\
\hline $\begin{array}{l}\text { Leonardo de } \\
\text { Medeiros }\end{array}$ & $\begin{array}{l}\text { Conexão ciência: um projeto } \\
\text { televisivo para divulgação da } \\
\text { produção científica nacional }\end{array}$ & $\begin{array}{l}\text { J ornalismo Científico; ciência; } \\
\text { televisão. }\end{array}$ \\
\hline $\begin{array}{l}\text { Mariana } \\
\text { Bittencourt } \\
\text { Weber }\end{array}$ & $\begin{array}{l}\text { Alerta vermelho: o cotidiano do } \\
\text { resgate na cidade de São Paulo }\end{array}$ & $\begin{array}{l}\text { J ornalismo; reportagem; resgate; } \\
\text { bombeiros. }\end{array}$ \\
\hline $\begin{array}{l}\text { Marina } \\
\text { Martins } \\
\text { Gonzales }\end{array}$ & $\begin{array}{l}\text { As donas de casa: } \\
\text { três mulheres na luta por } \\
\text { moradia em São Paulo }\end{array}$ & $\begin{array}{l}\text { Movimento popular de moradia; } \\
\text { habitação; mutirão; autogestão; sem- } \\
\text { teto; São Paulo. }\end{array}$ \\
\hline $\begin{array}{l}\text { Ruth Pinheiro } \\
\text { Costas }\end{array}$ & $\begin{array}{l}\text { A Guerra na TV: } \\
\text { Uma análise da cobertura da } \\
\text { guerra no Iraque em } 2003\end{array}$ & $\begin{array}{l}\text { Jornalismo internacional; censura; } \\
\text { cobertura de guerra; televisão; } \\
\text { I raque. }\end{array}$ \\
\hline $\begin{array}{l}\text { Saulo Duarte } \\
\text { Passos Filho }\end{array}$ & $\begin{array}{l}\text { Gerenciamento de crises: seus } \\
\text { modelos, casos e o papel da } \\
\text { assessoria de comunicação }\end{array}$ & $\begin{array}{l}\text { Crise; gerenciamento; imagem; } \\
\text { corporação; assessoria de } \\
\text { comunicação. }\end{array}$ \\
\hline
\end{tabular}




\section{Segundo semestre de 2003 - J ornalismo Noturno}

\begin{tabular}{|c|c|c|}
\hline Discente & Título & Palavras-chave \\
\hline $\begin{array}{l}\text { Ana Lúcia } \\
\text { Berndt }\end{array}$ & $\begin{array}{l}\text { A visão da mídia sobre a } \\
\text { medicina complementar }\end{array}$ & $\begin{array}{l}\text { Revistas; editoração; projeto gráfico; } \\
\text { revistas brasileiras. }\end{array}$ \\
\hline $\begin{array}{l}\text { Anselmo M. } \\
\text { Massad }\end{array}$ & $\begin{array}{l}\text { Fontes de Informação: as vozes } \\
\text { ouvidas nas revistas semanais }\end{array}$ & $\begin{array}{l}\text { ornalismo; Brasil; revistas } \\
\text { brasileiras; fontes de informação. }\end{array}$ \\
\hline $\begin{array}{l}\text { Carolina de } \\
\text { Araújo } \\
\text { Monteiro }\end{array}$ & Enfermeiro do Inferno & $\begin{array}{l}\text { J ornalismo literário; Brasil; livros- } \\
\text { reportagem; repórteres e } \\
\text { reportagens. }\end{array}$ \\
\hline $\begin{array}{l}\text { Christopher } \\
\text { David S. } \\
\text { Langner }\end{array}$ & $\begin{array}{l}\text { Forbes Brasil: a falência do } \\
\text { jornalismo }\end{array}$ & $\begin{array}{l}\text { Jornalismo de negócios; Brasil; } \\
\text { revistas brasileiras; análise de } \\
\text { conteúdo; Forbes Brasil (revista). }\end{array}$ \\
\hline $\begin{array}{l}\text { Eliza Ribeiro } \\
\text { Capai }\end{array}$ & Vertigem & $\begin{array}{l}\text { Teatro; Brasil; grupos teatrais; } \\
\text { documentário; Cia Teatro da } \\
\text { Vertigem. }\end{array}$ \\
\hline $\begin{array}{l}\text { Erika } \\
\text { Yamamoto }\end{array}$ & $\begin{array}{l}\text { Retrato Fotográfico: de objeto } \\
\text { particular a imagem coletiva }\end{array}$ & $\begin{array}{l}\text { História da fotografia; fotojornalismo; } \\
\text { retrato (fotografia). }\end{array}$ \\
\hline $\begin{array}{l}\text { Fábio Luis } \\
\text { Pedroso }\end{array}$ & Prisão: uma tecnologia defasada & Prisões; punição; Direito penal. \\
\hline $\begin{array}{l}\text { Felipe Carion } \\
\text { Braz }\end{array}$ & $\begin{array}{l}\text { A construção do estereótipo do } \\
\text { sucesso profissional em revistas } \\
\text { de negócio especializadas }\end{array}$ & $\begin{array}{l}\text { Jornalismo de negócio; Brasil; } \\
\text { revistas brasileiras; análise de } \\
\text { conteúdo; sucesso profissional; Você } \\
\text { S.A. }\end{array}$ \\
\hline $\begin{array}{l}\text { Fernando F. } \\
\text { de A. Mello }\end{array}$ & A Era Teixeira & J ornalismo esportivo; Brasil; Futebol. \\
\hline $\begin{array}{l}\text { Gustavo } \\
\text { Barreto } \\
\text { Prudente }\end{array}$ & $\begin{array}{l}\text { Sopa de Pizza - Histórias de } \\
\text { gente diferente }\end{array}$ & $\begin{array}{l}\text { J ornalismo literário; Brasil; livros- } \\
\text { reportagem; repórteres e } \\
\text { reportagens; fissura labiopalatina. }\end{array}$ \\
\hline $\begin{array}{l}\text { Jacques } \\
\text { Gomes Filho }\end{array}$ & $\begin{array}{l}\text { You Are Welcome!: a influência } \\
\text { da brasilidade no trabalho de } \\
\text { correspondência jornalística } \\
\text { internacional }\end{array}$ & $\begin{array}{l}\text { J ornalismo - Brasil; notícias } \\
\text { internacionais; identidade cultural; } \\
\text { jornalistas brasileiros. }\end{array}$ \\
\hline $\begin{array}{l}\text { Julienne } \\
\text { Gananian }\end{array}$ & $\begin{array}{l}\text { Introdução à história da } \\
\text { fotografia de imprensa no Brasil } \\
(1920-1945)\end{array}$ & $\begin{array}{l}\text { Fotografia; história da fotografia; } \\
\text { fotografia no Brasil; jornalismo; } \\
\text { fotojornalismo. }\end{array}$ \\
\hline $\begin{array}{l}\text { Luciana } \\
\text { Vasques } \\
\text { Farnesi }\end{array}$ & $\begin{array}{l}\text { O Brasil e a Reforma do } \\
\text { Conselho de Segurança das } \\
\text { Nações Unidas }\end{array}$ & $\begin{array}{l}\text { Política externa; Brasil; jornalismo } \\
\text { internacional; relações internacionais; } \\
\text { Conselho de Segurança das Nações } \\
\text { Unidas. }\end{array}$ \\
\hline $\begin{array}{l}\text { Luiz Roberto } \\
\text { de Souza } \\
\text { Júnior }\end{array}$ & $\begin{array}{l}\text { Hemingway Hadley em Paris: os } \\
\text { caminhos para se tornar um } \\
\text { escritor nos anos } 20\end{array}$ & $\begin{array}{l}\text { Literatura; Estados Unidos; século } \\
\text { vinte; escritores norte- americanos; } \\
\text { HEMINGWAY, Ernest Miller, 1898- } \\
1961 .\end{array}$ \\
\hline $\begin{array}{l}\text { Marcy } \\
\text { Picanço de } \\
\text { Figueiredo }\end{array}$ & $\begin{array}{l}\text { Lições de Comunicação: } \\
\text { moradores do Capão Redondo } \\
\text { analisam e experimentam o } \\
\text { jornalismo }\end{array}$ & $\begin{array}{l}\text { Jornalismo; aspectos sociais; } \\
\text { jornalismo comunitário; Capão } \\
\text { Redondo (SP); São Paulo (SP); } \\
\text { bairros. }\end{array}$ \\
\hline
\end{tabular}




\begin{tabular}{|l|l|l|}
\hline $\begin{array}{l}\text { Mariana } \\
\text { Iwakura }\end{array}$ & $\begin{array}{l}\text { Horizonte: a terceira idade e o } \\
\text { lazer como sua principal } \\
\text { atividade }\end{array}$ & Terceira idade; lazer; gerontologia. \\
\hline $\begin{array}{l}\text { Rafaela } \\
\text { Gagnebin } \\
\text { Müller }\end{array}$ & $\begin{array}{l}\text { Giratempo: cultura caipira e } \\
\text { novos significados para a } \\
\text { tradição }\end{array}$ & $\begin{array}{l}\text { Cultura popular; São Paulo; música } \\
\text { caipira; jornalismo cultural. }\end{array}$ \\
\hline $\begin{array}{l}\text { Tatiana } \\
\text { Uemura }\end{array}$ & $\begin{array}{l}\text { Terceiro Setor: uma proposta de } \\
\text { um suplemento para o jornal } \\
\text { Folha de S.Paulo }\end{array}$ & $\begin{array}{l}\text { Jornalismo; aspectos sociais; jornais } \\
\text { brasileiros; São Paulo; terceiro setor; } \\
\text { Folha de S Paulo (jornal). }\end{array}$ \\
\hline $\begin{array}{l}\text { Thaís Yuri } \\
\text { Tanaka de } \\
\text { Almeida }\end{array}$ & A vida sobre rodas & $\begin{array}{l}\text { TCC; documentário; vídeo; } \\
\text { deficiência; deficiente; deficiente } \\
\text { físico; cadeira de rodas; São Paulo. }\end{array}$ \\
\hline $\begin{array}{l}\text { Thiago Mio } \\
\text { Salla }\end{array}$ & $\begin{array}{l}\text { Crônica: jornalismo em } \\
\text { Graciliano Ramos }\end{array}$ & $\begin{array}{l}\text { Jornalismo e literatura; Brasil; } \\
\text { jornalismo; crônicas; RAMOS, } \\
\text { Graciliano Ramos, 1892- 1954. }\end{array}$ \\
\hline
\end{tabular}




\subsection{Da Apresentação e da Análise dos Dados da Pesquisa}

Buscamos a presença da cidadania e temas correlatos nos 55 (cinqüenta e cinco) projetos experimentais da amostra a partir dos títulos e resumos ${ }^{49}$, nessa ordem. Em todos os trabalhos foram lidos, além desses dois itens, a sua introdução.

Para efeitos demonstrativos, elaboramos o quadro a seguir em que apresentamos nominalmente o discente, o título do trabalho e seu resumo. Em seguida, elaboramos nossas considerações sobre a relação do referido projeto experimental com a cidadania. Nos TCCs em que encontramos a presença mais enfática da cidadania, avançamos na leitura do seu conteúdo como condição para elaborarmos nossas considerações.

Neste item, adotamos como palavras-chave para as observações sobre a presença da cidadania nos trabalhos os conceitos de democracia e de direitos humanos em detrimento dos conceitos da ética e da responsabilidade social do jornalismo por entendermos que aqueles já pressupõem estes últimos.

\footnotetext{
${ }^{49}$ Alguns trabalhos não apresentavam resumos. Nesses casos, valemo-nos da sua introdução.
} 


\section{Primeiro semestre de 2002 - Jornalismo Noturno}

\begin{tabular}{|c|c|c|c|}
\hline Discente & Título $^{50}$ & Resumo $^{51}$ & Relação com a cidadania \\
\hline $\begin{array}{l}\text { Adriana } \\
\text { Fernandes } \\
\text { Farias }\end{array}$ & $\begin{array}{l}\text { Reforma } \\
\text { psiquiátrica } \\
\text { no Brasil: } \\
\text { um caminho } \\
\text { a percorrer }\end{array}$ & $\begin{array}{l}\text { “Resta muito a percorrer nesse caminho de reformas. Mas se o Brasil } \\
\text { percorrê-lo com determinação (leia-se: vontade política), minimizará a } \\
\text { exclusão social de que sofrem os portadores de distúrbio mental e } \\
\text { conseguirá, enfim, dar uma verdadeira chance à recuperação” (pg. 5). }\end{array}$ & $\begin{array}{l}\text { DIREITOS HUMANOS: a cidadania civil } \\
\text { e social é abordada sob a ótica da } \\
\text { saúde mental, discutindo a } \\
\text { responsabilidade social e } \\
\text { governamental com o problema. }\end{array}$ \\
\hline $\begin{array}{l}\text { Ana Carolina } \\
\text { Saito }\end{array}$ & $\begin{array}{l}\text { Ensaio sobre } \\
\text { a opinião } \\
\text { pública } \\
\text { política: Kant } \\
\text { segundo } \\
\text { Hannah } \\
\text { Arendt }\end{array}$ & $\begin{array}{l}\text { O objetivo deste trabalho é resgatar a perspectiva kantiana sobre a } \\
\text { opinião pública, considerando o conflito verdade e política. Mentir e } \\
\text { manter segredo, práticas muitas vezes justificada pela política, são } \\
\text { condenadas por Kant do ponto de vista moral. Para o filósofo, dizer a } \\
\text { verdade é um dever ético e jurídico independente de qualquer condição. } \\
\text { (...). Estas interpretações podem ( ser) retomadas a partir da } \\
\text { interpretação de Hannah Arendt. Para a autora, o mundo da política é } \\
\text { onde prevalecem o jogo de interesses, a coerção e a dominação. Neste } \\
\text { sentido, a verdade não escaparia da ação demolidora da política. }\end{array}$ & $\begin{array}{l}\text { DEMOCRACIA: ao unir Kant e Arendt } \\
\text { para discutir a questão da opinião } \\
\text { pública, esse ensaio revigora uma das } \\
\text { principais questões da política, da } \\
\text { democracia e da cidadania } \\
\text { contemporâneas. }\end{array}$ \\
\hline $\begin{array}{l}\text { Marina } \\
\text { Motomura } \\
\text { Gonçalves } \\
\text { Vieira }\end{array}$ & $\begin{array}{l}\text { A vida no } \\
\text { arame }\end{array}$ & $\begin{array}{l}\text { “Ainda são poucos os estudiosos de circo nas principais universidades } \\
\text { brasileiras (a USP, maior universidade do país, não registra nenhum), } \\
\text { mas há incipientes discussões para pensar - e não deixar morrer - o circo } \\
\text { brasileiro. Um evento importante, nesse sentido, foi realizado em } \\
\text { setembro do ano passado em Belo Horizonte. Foi o I Festival Mundial de } \\
\text { Circo no Brasil, que reuniu desde intelectuais a artistas. Uma nova edição } \\
\text { deve acontecer ainda esse ano” (pg. 13). }\end{array}$ & $\begin{array}{l}\text { DIREITOS HUMANOS: o trabalho } \\
\text { resgata um assunto pouco abordado } \\
\text { nas temáticas acadêmicas: o circo e, de } \\
\text { modo indireto, discute questões como } \\
\text { trabalho e direitos sociais. }\end{array}$ \\
\hline $\begin{array}{l}\text { Rafael Fontana } \\
\text { Garcia }\end{array}$ & $\begin{array}{l}\text { A } \\
\text { universidade } \\
\text { no caminho } \\
\text { da exclusão } \\
\text { social }\end{array}$ & $\begin{array}{l}\text { “Esta reportagem tem por objetivo mostrar os pólos do nó social que } \\
\text { sustenta o processo da elitização da universidade pública e mostrar que } \\
\text { isso pode afetar a desigualdade social de um modo geral” (s / no. pág.). }\end{array}$ & $\begin{array}{l}\text { DEMOCRACIA: o texto aponta que o } \\
\text { difícil acesso de algumas camadas à } \\
\text { universidade pública antes de } \\
\text { representar uma desigualdade em si } \\
\text { mesma, é um sintoma de uma crise } \\
\text { social mais generalizada no País. }\end{array}$ \\
\hline
\end{tabular}

${ }^{50}$ Os títulos e resumos estão apresentados respeitando a forma como foram disponibilizados pelos alunos em seus trabalhos ou como constavam nos cadastros digitais da biblioteca da ECA. Em alguns momentos fizemos uma ou outra alteração, como edição dos resumos.

${ }^{51}$ Alguns trabalhos desta amostragem não apresentavam resumo. Por isso, transcrevemos, em alguns casos, trechos da introdução. 


\section{Segundo semestre de 2002 - Jornalismo Noturno}

\begin{tabular}{|c|c|c|c|}
\hline Discente & Título & Resumo & Relação com a cidadania \\
\hline $\begin{array}{l}\text { Lidia Gurgel } \\
\text { Neves }\end{array}$ & $\begin{array}{l}\text { Classes } \\
\text { Populares no } \\
\text { Jornalismo: } \\
\text { Uma análise } \\
\text { dos estigmas } \\
\text { sob a ótica }\end{array}$ & $\begin{array}{l}\text { Os meios de comunicação cumprem hoje o papel de dar visibilidade aos } \\
\text { temas considerados mais importantes na sociedade, dando informações } \\
\text { para que os cidadãos possam formar suas opiniões e participar da esfera } \\
\text { pública democrática. Numa sociedade em que apenas a elite tem acesso } \\
\text { à decisão sobre os assuntos pautados nos jornais e à produção de seus } \\
\text { conteúdos, a imagem das classes populares nos jornais se forma a partir } \\
\text { de uma visão externa, baseada nos estigmas que Ihes são atribuídos por } \\
\text { aqueles que têm acesso produzir as informações. Partindo destes } \\
\text { princípios, este trabalho se propõe a analisar os estigmas sociais das } \\
\text { classes populares nos jornais paulistas Folha de S. Paulo e O Estado de S. } \\
\text { Paulo, com o objetivo de pensar o papel do jornalismo na construção de } \\
\text { uma sociedade democrática. }\end{array}$ & $\begin{array}{l}\text { DEMOCRACIA: a questão da visibilidade } \\
\text { e da imagem das classes populares na } \\
\text { mídia são trazidos à ordem do dia como } \\
\text { uma forma de discutir a cidadania no } \\
\text { que diz respeito aos direitos civis e } \\
\text { sociais do cidadão brasileiro. }\end{array}$ \\
\hline $\begin{array}{l}\text { Márcio } \\
\text { Kameoka }\end{array}$ & $\begin{array}{l}\text { Fome no } \\
\text { Brasil: } \\
\text { Caminhos } \\
\text { trilhados e a } \\
\text { distância por } \\
\text { percorrer }\end{array}$ & $\begin{array}{l}\text { A fome é assunto de debates no Brasil há mais de } 60 \text { anos, desde Josué } \\
\text { de Castro, mas faz parte da realidade do País desde o Descobrimento. } \\
\text { Este pequeno livro versa sobre as idas e vindas da discussão e do } \\
\text { combate à fome, retratando a última década e as expectativas com } \\
\text { relação ao Governo Lula, recém empossado. O significado do termo } \\
\text { Segurança Alimentar e Nutricional e as discussões que o constituíram no } \\
\text { Brasil. Também é discutido o direito humano à Alimentação, instância do } \\
\text { Direito Internacional ainda necessitando de definição. }\end{array}$ & $\begin{array}{l}\text { DEMOCRACIA: inspirado em } \\
\text { regulamentações nacionais e } \\
\text { internacionais, o trabalho discute a } \\
\text { alimentação como um direito humano, } \\
\text { levando ao público informações sobre a } \\
\text { responsabilidade do governo brasileiro } \\
\text { com a questão. }\end{array}$ \\
\hline $\begin{array}{l}\text { Márcio } \\
\text { Tucunduva de } \\
\text { Faria }\end{array}$ & $\begin{array}{l}\text { Adolescência } \\
\text { Positiva: } \\
\text { Documen- } \\
\text { tário sobre } \\
\text { adolescentes } \\
\text { HIV - } \\
\text { positivos de } \\
\text { transmissão } \\
\text { vertical }\end{array}$ & $\begin{array}{l}\text { O objetivo do documentário Adolescência Positiva é mostrar a situação } \\
\text { dos adolescentes portadores do vírus HIV infectados verticalmente e de } \\
\text { que maneira essas pessoas se relacionam com profissionais no instituto } \\
\text { de infectologia mais importante do País, o Hospital Emílio Ribas, em São } \\
\text { Paulo. Mais do que isso, visa explicitar as relações pessoais desses jovens } \\
\text { em seu ambiente familiar, nas Casas de Apoio e entre indivíduos da } \\
\text { mesma faixa etária, portadores ou não do vírus causador da AIDS. }\end{array}$ & $\begin{array}{l}\text { DIREITOS HUMANOS: partindo da } \\
\text { necessidade de revisão das regras } \\
\text { sociais de convivência a partir do } \\
\text { advento da aids e da descoberta do } \\
\text { HIV, o trabalho retoma a discussão da } \\
\text { cidadania brasileira em especial no que } \\
\text { diz respeito ao jovem. }\end{array}$ \\
\hline
\end{tabular}




\begin{tabular}{|l|l|l|l|}
\hline $\begin{array}{l}\text { Nádia Barba } \\
\text { Chiqueta }\end{array}$ & $\begin{array}{l}\text { Mulheres e } \\
\text { Grades }\end{array}$ & $\begin{array}{l}\text { O documentário Mulheres e Grades aborda a problemática referente ao } \\
\text { aumento da criminalidade entre as mulheres nas últimas décadas. A } \\
\text { partir de cinco histórias de mulheres que cumprem pena na Penitenciária } \\
\text { Feminina do Butantan em São Paulo, o documentário traça um panorama } \\
\text { da vida e rotina das mulheres presas. }\end{array}$ & $\begin{array}{l}\text { DIREITOS HUMANOS: a cidadania } \\
\text { feminina e o respeito à mulher } \\
\text { encarcerada são colocadas em pauta no } \\
\text { trabalho. }\end{array}$ \\
\hline $\begin{array}{l}\text { Laura M. } \\
\text { Gianecchini }\end{array}$ & $\begin{array}{l}\text { Revista "Dois } \\
\text { Pontos" }\end{array}$ & $\begin{array}{l}\text { A Revista Dois Pontos, apresenta as desigualdades sociais brasileiras a } \\
\text { partir de um único tema: O número zero associa energia elétrica a } \\
\text { problemas sociais. }\end{array}$ & $\begin{array}{l}\text { DEMOCRACIA: o trabalho, inspirado no } \\
\text { clássico paradigma jornalístico dos } \\
\text { diferentes lados de cada questão, } \\
\text { discute as questões sociais a partir do } \\
\text { direito cidadão a uma infra- estrutura } \\
\text { básica como a energia elétrica. }\end{array}$ \\
\hline
\end{tabular}




\section{Primeiro semestre de 2003 - Jornalismo Noturno}

\begin{tabular}{|c|c|c|c|}
\hline $\begin{array}{l}\text { Discente / } \\
\text { Docente } \\
\text { orientador }\end{array}$ & Título & Resumo & Relação com a cidadania \\
\hline $\begin{array}{l}\text { Ana Paula } \\
\text { Ziglio de } \\
\text { Andrade }\end{array}$ & $\begin{array}{l}\text { Somos } \\
\text { Franceses: } \\
\text { como vivem } \\
\text { os ciganos } \\
\text { na França do } \\
\text { século XXI }\end{array}$ & $\begin{array}{l}\text { Livro-reportagem sobre como vivem hoje os ciganos franceses e como } \\
\text { são vistos pelas políticas governamentais e organizações civis. Através de } \\
\text { histórias pessoais de ciganos sedentários e viajantes do sudeste da } \\
\text { França, o livro mostra como conseguem manter suas tradições e seu } \\
\text { peculiar modo de vida em meio a uma sociedade que historicamente } \\
\text { nunca aceitou sua cultura. Também conta a história dos profissionais } \\
\text { gadjés (não-ciganos) que conseguem fazer parte do universo cigano e } \\
\text { trabalham como intermediários entre os interesses ciganos, dos órgãos } \\
\text { oficiais e da população francesa gadjé. Esse livro é um trabalho } \\
\text { experimental que emprega a narrativa característica do jornalismo } \\
\text { literário para mostrar a difícil convivência ainda hoje entre os valores } \\
\text { franceses de "Liberdade, Igualdade e Fraternidade" e a ânsia de liberdade } \\
\text { do povo cigano. }\end{array}$ & $\begin{array}{l}\text { DIREITOS HUMANOS: mais que } \\
\text { resgatar a vida dos ciganos, o livro } \\
\text { mostra os entraves e caminhos para a } \\
\text { preservação da cultura - e da } \\
\text { identidade - de um povo, resgatando } \\
\text { os deveres e direitos da cidadania civil. }\end{array}$ \\
\hline $\begin{array}{l}\text { Fabiana } \\
\text { Vezzali }\end{array}$ & $\begin{array}{l}\text { Do mesmo } \\
\text { lado do } \\
\text { balcão: } \\
\text { as relações } \\
\text { entre } \\
\text { jornalistas e } \\
\text { assessores } \\
\text { de imprensa }\end{array}$ & $\begin{array}{l}\text { Este trabalho pretende discutir a relação entre jornalistas e assessores de } \\
\text { imprensa na prática da reportagem. Quer também observar como se dá a } \\
\text { negociação entre jornalistas e assessores sob a perspectiva de uma } \\
\text { relação dependente e conflituosa, com códigos de conduta baseados em } \\
\text { critérios e laços pessoais e na informalidade. Essa relação será discutida } \\
\text { sob o ponto de vista de repórteres e de assessores, refutando a } \\
\text { tendência de condenar a priori as assessorias de imprensa como meras } \\
\text { interessadas em negócios mercadológicos e praticantes de um } \\
\text { antijornalismo. Para isso, serão analisados aspectos do jornalismo atual, } \\
\text { as condições de trabalho dos jornalistas e as diferentes concepções sobre } \\
\text { o trabalho em assessoria de imprensa. }\end{array}$ & $\begin{array}{l}\text { DEMOCRACIA: nesse trabalho de auto- } \\
\text { referência, o jornalismo se debruça } \\
\text { sobre ele mesmo para refletir sobre seu } \\
\text { "fazer", sobre os princípios éticos da } \\
\text { profissão e sobre a conduta moral de } \\
\text { seus profissionais. }\end{array}$ \\
\hline Gustavo Schor & $\begin{array}{l}\text { A tenacidade } \\
\text { de genes e } \\
\text { sonhos }\end{array}$ & $\begin{array}{l}\text { O livro-reportagem A Tenacidade de Genes e Sonhos: Os } 50 \text { Anos do } \\
\text { Hospital do Câncer é uma narrativa sobre a dignidade e humanização de } \\
\text { gerações de médicos, cientistas, pacientes e voluntários, que criara m } \\
\text { uma malha solidária para combater uma doença tida, há meio século, } \\
\text { como incurável (...). }\end{array}$ & $\begin{array}{l}\text { DEMOCRACIA: aqui a cidadania é } \\
\text { apresentada como um dever, seja do } \\
\text { Estado, seja de iniciativas particulares. }\end{array}$ \\
\hline
\end{tabular}




\begin{tabular}{|c|c|c|c|}
\hline $\begin{array}{l}\text { Leonardo de } \\
\text { Medeiros }\end{array}$ & $\begin{array}{l}\text { Conexão } \\
\text { ciência: um } \\
\text { projeto } \\
\text { televisivo } \\
\text { para a } \\
\text { divulgação } \\
\text { da produção } \\
\text { científica } \\
\text { nacional }\end{array}$ & $\begin{array}{l}\text { Este trabalho tem como proposta desenvolver um projeto de programa } \\
\text { jornalístico para a televisão cujo foco é a ciência produzida no Brasil. Para } \\
\text { dar embasamento ao projeto, elaborou-se um estudo sobre o jornalismo } \\
\text { científico, sobre os conceitos científicos e sobre os números da produção } \\
\text { acadêmica no Brasil. Além disso, foi desenvolvida uma pesquisa sobre os } \\
\text { programas especializados em C\&T exibidos nos canais VHF de São Paulo. }\end{array}$ & $\begin{array}{l}\text { DEMOCRACIA: a proposta pauta o } \\
\text { direito à informação, em especial à } \\
\text { informação científica. }\end{array}$ \\
\hline $\begin{array}{l}\text { Mariana } \\
\text { Bittencourt } \\
\text { Weber }\end{array}$ & $\begin{array}{l}\text { Alerta } \\
\text { vermelho: } \\
\text { o cotidiano } \\
\text { do resgate } \\
\text { na cidade de } \\
\text { São Paulo } \\
\end{array}$ & $\begin{array}{l}\text { Este trabalho pretende retratar o cotidiano do Projeto Resgate na cidade } \\
\text { de São Paulo a partir de depoimentos dos profissionais que atuam no } \\
\text { serviço. O foco escolhido, portanto, são as situações enfrentadas por } \\
\text { bombeiros, médicos e enfermeiros no dia-a-dia das atividades de } \\
\text { salvamento (...). }\end{array}$ & $\begin{array}{l}\text { DEMOCRACIA: o trabalhador e o seu } \\
\text { trabalho são enfocados como partes } \\
\text { indissociáveis da cidadania civil e social. }\end{array}$ \\
\hline $\begin{array}{l}\text { Marina Martins } \\
\text { Gonzales }\end{array}$ & $\begin{array}{l}\text { As donas de } \\
\text { casa: três } \\
\text { mulheres na } \\
\text { luta por } \\
\text { moradia em } \\
\text { São Paulo }\end{array}$ & $\begin{array}{l}\text { O déficit habitacional na região metropolitana de São Paulo é calculado } \\
\text { em quase } 600 \text { mil unidades. (...) Somente na capital, mais de um milhão } \\
\text { de pessoas vivem em cerca de duas mil favelas. Nas regiões centrais e } \\
\text { nas periferias, mulheres em sua maioria, organizam- se e lutam pela } \\
\text { solução desse problema. Esta reportagem busca captar o processo de } \\
\text { luta pela casa própria e a articulação dos movimentos populares de } \\
\text { moradia na cidade a partir da história de três mulheres que militam } \\
\text { nesses movimentos. O objetivo é apresentar a organização e as } \\
\text { propostas dessas entidades, a influência que exercem nas políticas } \\
\text { públicas de habitação e o que acontece depois que se consegue a casa. }\end{array}$ & $\begin{array}{l}\text { DIREITOS HUMANOS: mulheres e } \\
\text { moradia são o foco do trabalho que } \\
\text { discute a cidadania principalmente no } \\
\text { âmbito dos direitos civis e sociais na } \\
\text { cidade de São Paulo. }\end{array}$ \\
\hline
\end{tabular}




\section{Segundo semestre de 2003 - Jornalismo Noturno}

\begin{tabular}{|c|c|c|c|}
\hline Discente & Título & Resumo & Relação com a cidadania \\
\hline $\begin{array}{l}\text { Fábio Luis } \\
\text { Pedroso }\end{array}$ & $\begin{array}{l}\text { Prisão: Uma } \\
\text { tecnologia } \\
\text { defasada }\end{array}$ & $\begin{array}{l}\text { O trabalho é um ensaio com viés jornalístico e acadêmico (ensaio- } \\
\text { reportagem) que pretende abordar a razão de ser da prisão. Para tal } \\
\text { propósito tomou- se a obra de Michael Foucault, "Vigiar e Punir", como } \\
\text { referência teórica. Por isso, a prisão foi vista em seus aspectos } \\
\text { repressivo, ressocializador e político (...) }\end{array}$ & $\begin{array}{l}\text { DIREITOS HUMANOS: a partir de } \\
\text { Foucault o autor questiona a viabilidade } \\
\text { e utilidade das prisões brasileiras como } \\
\text { um instrumento efetivo de correção } \\
\text { social e, por que não dizer, pró- } \\
\text { cidadania. }\end{array}$ \\
\hline $\begin{array}{l}\text { Gustavo } \\
\text { Barreto } \\
\text { Prudente }\end{array}$ & $\begin{array}{l}\text { Sopa de } \\
\text { Pizza - } \\
\text { Histórias de } \\
\text { gente } \\
\text { diferente }\end{array}$ & $\begin{array}{l}\text { Sopa de Pizza: histórias de gente diferente é um livro reportagem sobre } \\
\text { fissura lábio-palatal, uma anomalia congênita. Reúne cinco narrativas } \\
\text { sobre pessoas envolvidas com o problema, intercaladas com pequenos } \\
\text { textos sobre profissionais do HRAC (Hospital de Reabilitação de } \\
\text { Anomalias Craniofaciais), um hospital de referência mundial no } \\
\text { tratamento da deficiência. Cada narrativa se vale de uma linguagem } \\
\text { diferente, e todas as histórias dos entrevistados misturam- se com } \\
\text { experiências do próprio autor, também portador da anomalia. }\end{array}$ & $\begin{array}{l}\text { DIREITOS HUMANOS: com bastante } \\
\text { leveza, o autor conta a história de } \\
\text { pessoas com fissura lábio-palatal e } \\
\text { toca, mais uma vez, na questão da } \\
\text { cidadania civil das minorias. }\end{array}$ \\
\hline $\begin{array}{l}\text { Marcy Picanço } \\
\text { de Figueiredo }\end{array}$ & \begin{tabular}{|l|} 
Lições de \\
Comunicação \\
: Moradores \\
do Capão \\
Redondo \\
analisam e \\
experimenta \\
mo \\
jornalismo
\end{tabular} & $\begin{array}{l}\text { Este trabalho apresenta uma reportagem sobre a participação de alguns } \\
\text { moradores do distrito Capão Redondo, na zona sul de São Paulo em, pelo } \\
\text { menos, um dos seguintes projetos sociais que abordam o tema da } \\
\text { comunicação: Programa de Comunicação Comunitária, Agência de } \\
\text { Notícias Capão On- line e Cenafoco (a discussão sobre tratamento das } \\
\text { classes populares no telejornalismo ocorrida neste projeto). A } \\
\text { reportagem mostra as reflexões sobre a imprensa e as mudanças na } \\
\text { atuação comunitária que os participantes tiveram depois de conhecerem, } \\
\text { nos projetos, técnicas básicas de jornalismo; produzirem material } \\
\text { jornalístico e também, receberem informações sobre a estrutura da } \\
\text { comunicação como, por exemplo, o dado de que a TV é concessão } \\
\text { pública. }\end{array}$ & $\begin{array}{l}\text { DIREITOS HUMANOS: a autora parte de } \\
\text { uma comunidade carente de São Paulo } \\
\text { para dirigir seu foco para a questão da } \\
\text { democratização da comunicação. Nesse } \\
\text { sentido, é reavivada a questão da } \\
\text { informação como elemento fomentador } \\
\text { da participação social e da cidadania. }\end{array}$ \\
\hline
\end{tabular}




\begin{tabular}{|c|c|c|c|}
\hline $\begin{array}{l}\text { Mariana } \\
\text { I wakura }\end{array}$ & $\begin{array}{l}\text { Horizonte: A } \\
\text { terceira } \\
\text { idade e o } \\
\text { lazer como } \\
\text { sua principal } \\
\text { atividade }\end{array}$ & $\begin{array}{l}\text { Esse trabalho tem como objetivo investigar as motivações da terceira } \\
\text { idade em relação ao lazer. Esta ocupação tornou-se a principal atividade } \\
\text { exercida pelos idosos que, não mais no exercício de uma atividade } \\
\text { remunerada, vêem se com tempo livre para aprender a dançar, tocar um } \\
\text { instrumento, freqüentar uma universidade e realizar velhos sonhos. A } \\
\text { vontade também de estar junto de outras pessoas com interesses } \\
\text { semelhantes e que pertencem à mesma faixa etária fazem desses } \\
\text { espaços de lazer lugares para se exercer o contato social. Mas é preciso } \\
\text { atentar para que essas atividades não se tornem somente passatempos } \\
\text { antes que a morte chegue. }\end{array}$ & $\begin{array}{l}\text { DIREITOS HUMANOS: o foco do } \\
\text { trabalho é a qualidade de vida e de } \\
\text { lazer dos idosos. Em pauta, os direitos } \\
\text { civis e sociais da terceira idade. }\end{array}$ \\
\hline $\begin{array}{l}\text { Rafaela } \\
\text { Gagnebin } \\
\text { Müller }\end{array}$ & $\begin{array}{l}\text { Giratempo: } \\
\text { Cultura } \\
\text { caipira e } \\
\text { novos } \\
\text { significados } \\
\text { para a } \\
\text { tradição }\end{array}$ & $\begin{array}{l}\text { Giratempo é uma reportagem que trata de festas, manifestações } \\
\text { musicais e danças da cultura caipira no estado de São Paulo. Narra e } \\
\text { descreve a Folia e a Festa do Divino de } 2003 \text { em duas cidades - São Luís } \\
\text { do Paraitinga e Mogi das Cruzes - e algumas apresentações de grupos de } \\
\text { cultura caipira em eventos da capital paulistana. Depois, são feitas } \\
\text { considerações teóricas sobre o significado e as funções dessa cultura, } \\
\text { inclusive como "reserva de tradição", além de uma breve discussão sobre } \\
\text { políticas culturais, turismo e eventos destinados a promover a cultura } \\
\text { caipira. }\end{array}$ & $\begin{array}{l}\text { DIREITOS HUMANOS: no trabalho são } \\
\text { resgatados elementos e manifestações } \\
\text { da cultura caipira, cujas peculiaridades } \\
\text { sobrevivem à cultura de massa. }\end{array}$ \\
\hline $\begin{array}{l}\text { Tatiana } \\
\text { Uemura }\end{array}$ & $\begin{array}{l}\text { Terceiro } \\
\text { Setor }\end{array}$ & $\begin{array}{l}\text { Este trabalho tem como objetivo apresentar uma proposta de um } \\
\text { suplemento mensal para o jornal Folha de S. Paulo para a discussão do } \\
\text { tema terceiro setor. }\end{array}$ & $\begin{array}{l}\text { DEMOCRACIA: a preocupação com } \\
\text { questões como a democratização da } \\
\text { comunicação no terceiro setor é o ponto } \\
\text { de partida para a proposta do } \\
\text { suplemento. }\end{array}$ \\
\hline $\begin{array}{l}\text { Thaís Yuri } \\
\text { Tanaka de } \\
\text { Almeida }\end{array}$ & $\begin{array}{l}\text { A vida sobre } \\
\text { rodas }\end{array}$ & $\begin{array}{l}\text { Michel, André e Mara. Três pessoas diferentes, uma cidade - São Paulo - } \\
\text { e uma mesma condição - vivem sobre uma cadeira de rodas. Michel } \\
\text { Fernandes é jornalista, tem } 28 \text { anos e possui uma deficiência física } \\
\text { progressiva que faz com que perca a coordenação de seus movimentos. } \\
\text { André Luiz Costa Taveira tem } 36 \text { anos, trabalha nos semáforos fazendo } \\
\text { exibições de basquete e possui seqüelas nas duas pernas causadas por } \\
\text { uma paralisia infantil. Mara Gabrilli tem } 35 \text { anos, é publicitária, psicóloga } \\
\text { e fundadora da organização não- governamental Projeto Primeiro Passo, } \\
\text { que atende deficientes físicos. Ela ficou tetraplégica após quebrar o } \\
\text { pescoço em um acidente de carro em } 1994 \text {. }\end{array}$ & $\begin{array}{l}\text { DIREITOS HUMANOS: três pessoas, } \\
\text { três caminhos, três lutas diferentes } \\
\text { pelos direitos civis e sociais do portador } \\
\text { de deficiência em São Paulo. }\end{array}$ \\
\hline
\end{tabular}


A última etapa da pesquisa, que toma como referência os projetos experimentais realizados pelos discentes do curso de Jornalismo noturno da ECA / USP nos anos 2002 e 2003, nos leva aos seguintes resultados:

1. A cidadania e temas correlatos aparecem claramente em 22 (vinte e dois) - 40\% - dos 55 (cinqüenta e cinco) trabalhos de conclusão do curso de J ornalismo do período noturno;

2. Os conceitos de cidadania, que aparecem nos 22 projetos, 12 (doze) - 54,5\% - trabalham com os direitos humanos de minorias, como deficientes, pessoas com HIV e mulheres e 10 (dez) - 45,5\% - apresentam questões associadas à democracia, como a ocupação de espaços físicos e democratização da comunicação.

Em Prisão: uma tecnologia defasada, ao trabalhar com presos e discutir as penitenciárias brasileiras, Fábio Luís Pedroso (2003: 56) ilustra a constatação:

No Brasil, os acontecimentos políticos, econômicos e sociais caminham na mesma direção. O que explica o recrudescimento do discurso de políticos e de autoridades públicas contra bandidos, argumentando retoricamente que 'lugar de bandido é na cadeia'; ou dando números e mais números para provar que o Estado não tem mais capacidade financeira par investir em novos presídios, ou para alegar que o gasto com presos atingiu um limite absurdo, sem que se vejam resultados satisfatórios, quando se sabe que esses resultados não são alcançados porque os presídios não têm infraestrutura adequada para ressocializar os internos; ou quando falam descaradamente que o orçamento para saúde, educação e lazer é reduzido. O que explica também o alarmismo da mídia em geral, expondo que o crime organizado está suplantando a capacidade do Estado em reagir ao crime, o que só contribui para intensificar a violência do Estado contra a população pobre, vítimamor deste estado de coisas. 
3. TODOS os TCCs que apresentam o conceito de cidadania ou temas correlatos partem do princípio ou apontam que o problema apresentado no projeto experimental pode ser resolvido na comunidade ao ser melhor trabalhado por uma mídia, seja ela institucional ou alternativa.

No projeto Lições de Comunicação: Moradores do Capão Redondo analisam e experimentam o J ornalismo, a autora Maria Otília Bocchini (2003: 43) deixa claro este pensamento ao falar da experiência de uma agência noticiosa na periferia de São Paulo:

O trabalho da Agência trouxe diversas mudanças para a vida dos participantes. Dentre elas, destaca-se a atuação comunitária: "Minha relação com o bairro mudou muito depois da Agência. Antes, eu era integrante da associação de moradores e monitora do Sampa.org, depois virei repórter. Virei a pessoa que a comunidade procurava para falar da enchente, para reclamar que foi mal atendida na administração regional. Eles tinham, de alguma forma, um canal aberto para tudo que estava acontecendo: quais os problemas, as festas legais, etc", comenta Cleide Ferreira, de 28 anos, que trabalha há sete na Associação de Moradores do Jardim Rosana. 


\section{Conclusão}

Todo o homem tem deveres para com a comunidade, na qual o livre e pleno desenvolvimento de sua personalidade é possível.

Artigo $X X I X$

da Declaração Universal dos Direitos Humanos

A análise dos dados da pesquisa permite-nos entender que a formação cidadã do jornalista da Escola de Comunicações e Artes da Universidade de São Paulo, não obstante apenas nos quatro primeiros semestres do curso tenha um caráter explicitamente curricular, ultrapassa esses limites.

A cidadania e os seus aspectos correlatos considerados neste trabalho - os direitos humanos, a democracia, a ética profissional e a responsabilidade social do jornalismo - não só respingam na formação que ocorre nos semestres seguintes, mas aparece ao longo de todo o curso na relação dos discentes com os docentes e na relação destes últimos com a vida acadêmica.

Parte da ementa da disciplina Laboratório de Iniciação ao Jornalismo, ofertada no segundo semestre do curso e que funciona como pré-requisito para os quatro laboratórios impressos seguintes ${ }^{52}$, deixa clara a intenção curricular:

(...) O jornalismo no universo dos valores: responsabilidade social e a questão ética. Percepção do olhar e relevância das coisas: a banalização da violência e do cotidiano.

\footnotetext{
52 As disciplinas laboratoriais seguintes são: Laboratório em Jornalismo I mpresso I (quarto semestre), Laboratório em Jornalismo Impresso II (quinto semestre), Laboratório em Jornalismo Impresso III (sexto semestre) e Laboratório em J ornalismo Impresso IV - Revista (oitavo semestre).
} 
Assim, a formação cidadã curricular iniciada nos quatro primeiros semestres do curso de Jornalismo noturno da ECA atinge a formação deste jornalista nos três outros momentos pesquisados neste trabalho: na produção laboratorial dos discentes, na sua relação com os docentes e nos projetos experimentais.

A relativa liberdade experimentada pelo estudante em relação à sua produção, ao gerenciamento da sua vida acadêmica (o que inclui também a própria flexibilidade curricular entre as disciplinas optativas) e o contato com idéias e debates políticos são uma vantagem inestimável para a formação cidadã do jornalista.

Esse mecanismo interfere positivamente na responsabilidade do aluno com a sua própria formação e, conseqüentemente, com o seu compromisso com o público já a partir da produção laboratorial, como constatou a pesquisa durante a produção do Jornal do Campus.

Apesar da crítica, o discente Vinícius Guilherme R. Vieira ${ }^{53}$ deixa clara a importância desta liberdade e responsabilidade:

Eu estou cursando uma disciplina na FFLECH, Política Comparada. Nós analisamos cidadania, evolução de direitos e políticas sociais em diversos países com foco, obviamente, no Brasil. Devido a esse meu interesse particular, estou tendo essa formação, mas no curso em geral essa formação é deficiente na medida em que deveria haver uma matéria específica para debater cidadania.

(...)

Por exemplo, se fala numa empresa cidadã, mas cidadania não está relacionada a empresas, porque uma empresa não pode garantir direitos a um cidadão. Ela faz aquilo digamos, por caridade, estaria mais numa concepção liberal do que na concepção de direitos que é assegurado pelo Estado, pelo fato de a pessoa ser cidadã. A mídia usa muito esse termo, creio eu, não tanto por uma questão de manipulação, mas por má formação do jornalista. Eu particularmente defendo que o jornalista deveria ter uma formação sólida em ciências humanas. Porque não basta comunicar.

(...)

O jornalista tem que compreender a realidade e os elementos dessa compreensão são dados, creio eu, permanentemente, pelas ciências humanas. Por isso que nós deveríamos ter uma ênfase maior para

\footnotetext{
${ }^{53}$ Depoimento integrante do conjunto das entrevistas com discentes de jornalismo realizadas por este autor.
} 
não incorremos nesses conceitos e fazermos uma ponte com a comunicação: ou seja, aplicarmos esses conceitos num jornal...

O trabalho de entrevistas com discentes também constata que para eles uma efetiva formação cidadã do jornalista tendo em vista uma atuação profissional comprometida com os seus valores fica especialmente comprometida num modelo de comunicação em que cada vez mais o mercado se sobrepõe ao compromisso social dos comunicadores. A discente Taís Bahov ${ }^{54}$ avalia a questão no dia a dia da profissão:

Quando você aceita trabalhar num veículo institucional você tem que seguir regras. Querendo ou não é uma empresa, e a necessidade de trabalhar acaba se sobrepondo. Eu não acredito que essas pessoas não tenham sido formadas ou que elas não se preocupem com a condição do cidadão ou com a mídia cidadã. Acredito que elas podem até se preocupar e levar projetos paralelos nos seus serviços, por quê não? Mas ali dentro é um ambiente em que prevalece a organização, a empresa.

O caso estudado aponta que não são os valores de mercado, mas os valores e os direitos humanos que estão na base da formação do jornalista ecano. Corroborando com os resultados desta pesquisa, Bucci (MORAES Jr, 2003: 16) observa que o mercado não pode ditar o que deve ser ensinado na faculdade. Ao contrário, cabe à academia dizer que tipo de mercado e de sociedade ela quer:

(...) a universidade não tem que formar contra o mercado, a favor do mercado nem segundo os interesses do mercado. A universidade tem que formar seres pensantes capazes de aprender constantemente, seres capazes de formular visão critica, individual em relação às coisas que o cercam e ao próprio mercado.

Além disso, a etapa da pesquisa junto aos docentes mostra que a consciência do professor em relação ao compromisso ético e à responsabilidade da imprensa com valores como a democracia e os

\footnotetext{
${ }^{54}$ Depoimento integrante do conjunto das entrevistas com discentes de jornalismo realizadas por este autor.
} 
direitos humanos são relevantes para a articulação da prática extracurricular da cidadania.

Embora a atual grade curricular do curso de Jornalismo da ECA contemple a cidadania nos primeiros semestres, ela é continuamente valorizada e trazida pelos professores como prática e ponto de discussão no conjunto das atividades do curso. O professor José Luís Proença opina sobre a sua experiência ${ }^{55}$ :

Todo o processo de estilo, edição e distribuição das informações são analisados sob o prisma da prática e do exercício da cidadania, sempre considerando que o jornalista é o responsável pela abertura das diversas vozes no espaço público.

Ao assimilar as relações da cidadania com o jornalismo no conteúdo curricular, no relacionamento com os professores, nas experiências laboratoriais e no próprio espaço acadêmico, a pesquisa demonstra que uma parte considerável dos alunos (40\%) leva esta experiência, direta ou indiretamente, para os trabalhos de conclusão de curso. A este respeito a professora Nancy N. Ali Ramadan ${ }^{56}$ observa em relação à sua experiência:

Nos trabalhos que orientei e nas bancas de que participei o tema está sempre presente, de uma forma direta ou não. São raros os trabalhos que deixam o tema totalmente esquecido.

Não obstante a formação curricular do jornalista seja extremamente importante para a apreensão do conceito de cidadania por fundamentá-lo teoricamente, este trabalho aponta que são cidadãos e espaços cidadãos que formam, de fato, cidadãos. Um currículo, um professor e uma prática laboratorial que não abrem o aluno para o diálogo com as diferenças e a realização das suas potencialidades dificilmente conseguem formar um jornalista comprometido com os

\footnotetext{
${ }^{55}$ Depoimento integrante das respostas a questionários com docentes de jornalismo realizadas por este autor. ${ }^{56}$ Idem.
} 
direitos humanos, como a democracia, com ética e com a responsabilidade social da profissão.

Pensando comparativamente em qual dos momentos da formação dos discentes do curso de Jornalismo (noturno) da ECA / USP a cidadania aparece com maior destaque, concluímos que o momento em que ela fica bastante clara é no currículo. Mas ao ultrapassar as fronteiras curriculares, numa perspectiva rogeriana (ROGERS: 1973), encontra no conjunto das experiências vividas e adquiridas na escola um caminho para maturá-la.

Este ponto, aliás, está em consonância com a concepção de Marshall (1967), para quem a educação é um pré-requisito para a cidadania civil, que deve funcionar como base para a construção da cidadania plena.

Os resultados do estudo sobre a formação cidadã do jornalista na ECA podem ser bastante eloqüentes em relação a outras escolas brasileiras, mas devem ser consideradas também as peculiaridades regionais. Entendemos ser importante o avanço deste tipo de estudo em outras unidades educacionais do País e de outros continentes, inclusive como forma de atribuir à cidadania a pujança que ela merece no currículo e nas demais instâncias de formação do profissional de jornalismo.

João Paulo Souza (2002: 33) constata que

O Modelo Ocidental de Jornalismo preconiza que a imprensa deve ser independente do estado e dos poderes, tendo o direito a reportar, comentar, interpretar e criticar as atividades dos agentes de poder, inclusive dos agentes institucionais, sem repressão ou ameaça de repressão. Teoricamente, os jornalistas seriam apenas limitados pela lei (tida como justa), pela ética e pela deontologia.

Até que ponto as escolas têm respeitado, de fato, este modelo de jornalismo comprometido com a cidadania? Entendemos que o compromisso do jornalismo com o interesse público e com a cidadania deveria ser não só melhor fundamentado como também, e 
principalmente, explicitado no projeto pedagógico ${ }^{57}$ de cada curso oferecido e, conseqüentemente, melhor explicitado no perfil de profissional proposto à sociedade e ao mercado.

Discutir a presença da cidadania na formação do jornalista hoje significa estimular uma reflexão de valores universais e, mais que isto, discutir o futuro das relações sociais numa nova forma de organização humana.

Para Gadotti (2000), as reflexões sobre educação neste novo milênio devem ter em vista uma cidadania não apenas nacional, baseada no conceito de Estado-nação, mas preocupada com uma comunidade planetária em que os indivíduos não mais podem ser vistos como parte de 'blocos', mas como pessoas que necessitam estabelecer laços de colaboração em nome da sobrevivência ecológica do próprio planeta.

Refletir sobre a formação que deve ser proposta ao estudante de Jornalismo é pensar, junto com ele, que tipo de mundo se quer para os próximos anos e se se quer, de fato, o jornalismo como um elemento integrador desta comunidade, comprometido com um modelo de informação 'correto, pleno e veraz'.

Transdisciplinaridade. Esta palavra talvez seja a que melhor resuma uma concepção de formação para os novos jornalistas. Uma primeira pista aparece tomando como referência Gadotti, quando o autor observa que na comunidade planetária o ensino passa a ser concebido não numa visão interdisciplinar, mas transdisciplinar. Gadotti (2000: 37), a partir de Piaget, delimita bem a questão:

(...) a interdisciplinaridade seria uma "forma de pensar" para chegar à transdisciplinaridade, isto é, uma etapa não apenas de interação entre as disciplinas, mas de "superação das fronteiras entre as ciências", sem opor uma à outra.

\footnotetext{
${ }^{57}$ Para Ramadan (2000: 112) “um projeto pedagógico deve ser entendido como um conjunto de pressupostos filosóficos e éticos que definem o papel do docente e suas escolhas, a atividade profissional que se tem em vista, o objetivo do curso - o perfil do profissional que se pretende oferecer à sociedade mediante a participação ativa de seus setores nesta discussão, a articulação de conteúdos e disciplinas em torno de instâncias teóricas e práticas, abrindo a possibilidade para os demais campos de conhecimento contribuírem".
} 
A convivência democrática com a diferença, com pontos de vista díspares (seja de autores, professores, colegas), complementares e inquietantes e, ao mesmo tempo, o exercício diário de lidar responsavelmente para si e para o outro (seja a fonte de informação, seja o público) com a diversidade talvez sejam grandes elementos propiciadores de uma formação cidadã. E isso só pode ser conseguido se a cidadania for discutida e praticada na escola.

Assim entendemos ser importante às novas e futuras escolas de Jornalismo, como parte do seu projeto pedagógico, o estímulo ao diálogo, à troca e a uma visão holística do aluno. Uma formação comprometida com a cidadania não só está centrada "na pessoa" do estudante, como observa Rogers (1973), mas também responsabiliza politicamente o educando. Nas palavras de Paulo Freire (1987: 67):

O que nos parece indiscutível é que, se pretendemos a libertação dos homens não podemos começar por aliená-los ou mantê-los alienados. A libertação autêntica, que é a humanização em processo, não é uma coisa que se deposita nos homens. Não é uma palavra a mais, oca, mitificante. É práxis, que implica a ação e a reflexão dos homens sobre o mundo para transformá-lo.

Os princípios da cidadania contemporânea encontram-se na Declaração Universal dos Direitos Humanos, cujos artigos, alguns deles, fizemos questão de assinalar na abertura dos capítulos da Parte I desta dissertação.

Embora a sua origem no sentido contemporâneo seja documental, falar em cidadania hoje é mais que falar em leis ou declarações. É falar em homens e em como esses homens se educam e vivenciam a ação (Arendt, 1987) que caracteriza sua condição humana.

Os princípios cidadãos estão, portanto e principalmente, no exercício, na construção e na reafirmação que os homens fazem deles. Parte dessa práxis consta na abertura dos capítulos da Parte II , mas um longo caminho ainda existe a ser trilhado. 
Se a cidadania contemporânea foi construída como um instrumento para fundamentar um mundo de desigualdades, como observa Wood (2003), é possível que numa comunidade planetária ela possa tornar-se um elemento de legitimação da igualdade. É possível também que neste contexto o jornalismo venha a ter uma função preponderante. Nesse sentido, a formação do jornalista precisa ser repensada e aprimorada visando a uma formação humanística crítica do seu profissional aliada ao conhecimento e ao manuseio das habilidades técnicas da profissão, unindo a 'Ética, a Técnica e a Estética' da notícia 'correta e plena' preocupada como o 'relato veraz', como observa Chaparro (1994).

O autor (2005) propõe a adoção de estratégias que integrem essas duas etapas de formação do jornalista em crescentes níveis de interação e complexidade, em espaços laboratoriais multidisciplinares. Esta formação dar-se-ia em três momentos:

Momento da I NI CI AÇÃO - Em nível de iniciação, e com carga horária preponderante, os alunos ingressantes deveriam ter acesso a conteúdos básicos de formação humanística, entre os quais, indispensáveis, História da Cultura e da Cidadania, História do Jornalismo, Ética e Deontologia, Economia, Ciência Política, Filosofia da Linguagem, Metodologia, Antropologia e Geografia (Política e Humana). Ao mesmo tempo, também em formato de iniciação nas técnicas jornalísticas, e com carga horária menor, mas crescente, os alunos devem dispor de espaços de aprendizado experimental, em projetos vivos, para práticas de jornalismo real, sem simulações.

Momento do APROFUNDAMENTO - Seria a fase mais alongada do curso, em que, no plano das idéias e da formação teórica, o caráter mais extensivo da iniciação daria lugar à possibilidade de escolhas para o estudo aprofundado (por meio de disciplinas optativas, por exemplo) em jornalismo e em no máximo duas áreas complementares de conhecimento, da preferência do aluno. Simultaneamente, a experimentação técnica cresceria em complexidade e carga horária, pedagogicamente inserida em espaços laboratoriais multidisciplinares, propícios às interações entre teoria e prática, espaços que, nesta fase, funcionariam como eixos do curso.

Momento da MATURAÇÃO - Seria o momento do atendimento pedagógico individualizado, preenchido com atividades orientadas de leituras, pesquisa e experimentação, para a produção do trabalho final de avaliação. Em um percurso de seis meses a um ano de estudo direcionado, em torno de um projeto ou de uma monografia, o aluno 
se defronta com seus limites e suas potencialidades, para demonstrar, de forma consolidada, os conhecimentos adquiridos e as aptidões desenvolvidas ao longo do curso.

Enfim, talvez o início do caminho para a superação das crises contemporâneas seja exatamente pensar e repensar a formação que é dada aos futuros profissionais nas escolas de ensino superior, a própria Educação e os valores sobre os quais ela se fundamenta.

A Educação é uma saída para as crises? Nílson Machado (1996: 305 / 306) responde a esta questão:

Sem dúvida, consideramos que sim. Naturalmente em tal asserção, considera-se a educação no sentido amplo, que inclui a educação escolar e a tem como elemento decisivo mas que nela não se esgota: a Educação que inclui a família, a comunidade, os meios de comunicação de massa, elementos imprescindíveis para a plena formação do cidadão.

(...) crises representam sempre transformações ou ausência de valores, transformações ou ausência de projetos que articulem as ações e contribuam para a construção de seus significados. A Educação é, por natureza, o lugar da construção de uma arquitetura de valores, de um projeto que harmonize motivações e interesses individuais e coletivos. A Educação é, portanto, o caminho para a saída de todas as crises.

A partir da constatação que apresentamos nas primeiras páginas desta dissertação sobre a interferência do atual processo de desenvolvimento da informação na educação e no trabalho, reafirmamos o pensamento de Gadotti (2000: 201):

Estamos assistindo ao nascimento do cidadão planetário. Ainda não conseguimos imaginar todas as conseqüências desse evento singular. No momento sentimos, percebemos, nos emocionamos com este fato, mas não conseguimos adequar nossas mentes e nossas formas de vida a esse evento espetacular na história de humanidade.

Trabalhar com cidadania em sua mão-dupla de direitos e deveres corresponde a um esforço permanente. Por que não dizer que aprender, ensinar e exercer cidadania são quase um compromisso de amor com o outro, com um outro-universal; com um outro-planetário? Neste aspecto não só a cidadania, mas quem sabe sua relação transdisciplinar 
com o amor ou com a poesia, ainda tenham muito a ensinar aos homens e às mulheres da ciência e também aos professores e aos estudantes de jornalismo.

Se a formação de um indivíduo e a cidadania estão em permanentemente em construção, esta pesquisa não poderia ser encerrada nesta dissertação. Por enquanto, ficaram apenas estas 'algumas' certezas. Deixemos que Fernando Pessoa nos fale neste final de expediente (GADOTTI, 2000: 169):

De tudo ficaram três coisas: a certeza de que estava sempre começando, a certeza de que era preciso continuar e a certeza de que seria interrompido antes de terminar.

Fazer da interrupção um caminho novo, fazer da queda um passo de dança, do medo uma escada, do sonho uma ponte, da procura, um encontro.

Ainda há muito se descobrir sobre "o mundo e as pessoas", por isso esta prazerosa aventura continua. 


\section{Bibliografia}

\section{Livros}

1. ARANHA, Mạ. Lúcia de A.; Martins, Mạ. Helena P. Filosofando: introdução à Filosofia. São Paulo: Moderna, 1995.

2. ARENDT, Hanna. A condição humana. Tradução de Roberto Raposo. Rio de Janeiro: Forense, 1987.

3. BAHIA, Juarez. Jornal, história e técnica: história da imprensa brasileira. São Paulo: Ática, 1990A.

4. - Jornal, História e Técnica: as técnicas do jornalismo. São Paulo: Ática, 1990B.

5. BARBOSA LIMA SOBRINHO, Alexandre José. O problema da imprensa. 4ạ ed. Coleção Clássicos do Jornalismo. São Paulo: Edusp, 2003.

6. BARBOSA, Rui. A imprensa e o dever da verdade. 4aa ed. Coleção Clássicos do J ornalismo. São Paulo: Edusp, 2003.

7. BELTRÃO, Luiz. Iniciação à Filosofia do jornalismo. 2ạ ed. Coleção Clássicos do J ornalismo. São Paulo: Edusp, 2003.

8. _-_-_. Metodos em la enseñanza de la técnica del periodismo. Quito: Ciespal, 1964. 
9. BODEI, Remo. Livro da Memória e da Esperança. Bauru: Edusc, 2004.

10. BLOOM, Benjamin S. Taxionomia de objetivos educacionais: domínio afetivo. Porto Alegre: Globo, 1973.

11. _-_--_ Taxionomia de objetivos educacionais: domínio cognitivo. Porto Alegre: Globo, 1973.

12. BUCCl, Eugênio. Sobre ética e imprensa. São Paulo: Cia. Das Letras, 2000.

13. CARVALHO, José Murilo de. Cidadania no Brasil: o longo caminho. Rio de Janeiro: Civilização Brasileira, 2003.

14. CASTELO BRANCO, Vitorino Prata. Curso de Jornalismo. São Paulo: Tipografia Cultura, 1945.

15. CATTANI, Afrânio Mendes; OLIVEIRA, João Ferreira de. A universidade pública no Brasil: identidade e projeto institucional em questão. In: TRINDADE, Hélio (org). Universidade em Ruínas: na república dos professores. Petrópolis: Vozes, 1999, p. 179-189.

16. CHAPARRO, Manuel Carlos. A pragmática do Jornalismo: buscas práticas para uma teoria da ação jornalística. São Paulo: Summus, 1994.

17. COSTA, Maria Cristina Castilho. Sociologia: introdução à Ciência da sociedade. São Paulo: Moderna, 1987. 
18. COVRE, Maria de Lourdes M. O que é cidadania. Coleção Primeiros Passos. São Paulo: Brasiliense, 2003.

19. CUNHA, Luiz Antônio. Educação, estado e democracia no Brasil. São Paulo: Cortez, 1991.

20. DUPAS, Gilberto. Ética e poder na sociedade da informação. 2ª ed. São Paulo: Unesp, 2001.

21. ERBOLATO, Mário. Técnicas de codificação em jornalismo. 5ạ ed. São Paulo: Ática, 1991.

22. FAUSTO, Boris. História do Brasil. 5a ed. São Paulo: USP, 1997.

23. FERRETTI, Celso João e outros. Novas tecnologias, trabalho e educação: um debate interdisciplinar. Petrópolis: Vozes, 1994.

24. FREIRE, Paulo. Pedagogia do oprimido. 17ạ ed. Rio de Janeiro: Paz e Terra, 1987.

25. - Educação como prática da liberdade. $23^{a}$ ed. Rio de Janeiro: Paz e Terra, 1999.

26. GADOTTI, Moacir. Pedagogia da terra. Série Brasil Cidadão. São Paulo: Pierópolis, 2000.

27. . Escola cidadã. 2a ed. São Paulo: Cortez, 1992.

28. GOODSON, Ivor F. Currículo: teoria e história. 2ª . ed. Petrópolis: Vozes, 1995. 
29. HOLFELDT, Antonio e BARBOSA, Marialva. Jornalismo no século XXI: a cidadania. Porto Alegre: Mercado Aberto, 2002.

30. IANNI. Octavio (org.). Marx. São Paulo: Ática, 1992.

31. JOBIM, Danton. O espírito do Jornalismo. 2ạ ed. Coleção Clássicos do J ornalismo. São Paulo: Edusp, 2003.

32. KOVACH, Bill; ROSENSTIEL. Elementos do jornalismo: o que os jornalistas devem saber e o público exigir. 2a ed. São Paulo: Geração Editorial, 2004.

33. KUNCZIK, Michael. Conceitos de J ornalismo norte e sul: manual de comunicação. 2a . ed. São Paulo: Edusp, 2002.

34. LACERDA, Carlos. A missão da imprensa. 2a ed. Coleção Clássicos do J ornalismo. São Paulo: Edusp, 2003.

35. LIMA, Alceu Amoroso. O Jornalismo como gênero literário. 2a ed. Coleção Clássicos do J ornalismo. São Paulo: Edusp, 2003.

36. LOPES, Eliane M. S. (org.). 500 anos de educação no Brasil. Belo Horizonte: Autêntica, 2000.

37. MACHADO, Nilson J. Epistemologia e didática: as concepções de conhecimento e inteligência e a prática docente. 2a ed. São Paulo: Cortez, 1996.

38. MARCONDES FILHO, Ciro. Jornalismo fin-de-siécle. São Paulo: Scritta, 1998. 
39. A saga dos cães perdidos. São Paulo: Hacker, 2000.

40. MARQUES DE MELO, José. Comunicação: teoria e política. São Paulo, Summus, 1985.

41. . Gêneros opinativos no jornalismo brasileiro.São Paulo: ECA / USP, 1983.

42. História do pensamento comunicacional: cenários e personagens. São Paulo: Paulus, 2003

43. MARQUES DE MELO, José; FADUL, Anamaria; SILVA, Carlos Eduardo Lins da. (orgs). I deologia e poder no ensino de comunicação. São Paulo: Cortez \& Moraes / Intercom, 1979.

44. MARSHALL, Thomas Humphrey. Cidadania, classe social e status. Rio de Janeiro: Zahar, 1967.

45. MAXIMO, Antônio Carlos. O intelectual e a educação das massas. Campinas: Autores Associados, 2000.

46. MELLO, Evaldo Cabral de (org.). Frei Joaquim do Amor Divino Caneca. São Paulo: Editora 34, 2001.

47. MOREL, Marcos. Frei Caneca entre Marília e a pátria. Rio de Janeiro: FGV, 2000.

48. MOREIRA, Antônio Flávio B; SILVA, Tomaz Tadeu da. (orgs.). Currículo, cultura e sociedade. 2ª . ed. São Paulo: Cortez, 1995. 
49. MOREIRA, Antônio Flávio B. Currículos e programas no Brasil. 3ạa ed. Papirus: Campinas, 1997.

50. PENTEAdO, Heloísa D. Pedagogia da comunicação: teoria e prática. São Paulo: Cortez, 1998.

51. PINSKY, Jaime; BASSANEZI, Carla (orgs.). História da cidadania. São Paulo: Contexto, 2002.

52. REALE, Giovanni; ANTISERI, Dario. História da Filosofia: patrística e escolástica. Vol. 02. São Paulo: paulus, 2003.

53. RIZZINI, Carlos. O ensino do Jornalismo. MEC: Rio de Janeiro, 1953.

54. ROGERS, Carl R.; ROSENBERG, Rachel L. Liberdade para aprender. São Paulo: Edusp 1977.

55. ROGERS, Carl R. A pessoa como centro. 2ª . ed. São Paulo: Martins Fontes, 1987.

56. . Tornar-se pessoa. Lisboa: Moraes Editores (Martins Fontes), 1973.

57. ROUSSEAU, Jean-Jacques. Do Contrato Social. Tradução de Márcio Pugliesi e Norberto de Paula Lima. São Paulo: Hemus, [s.d.].

58. SANTOS, Boaventura de Sousa (org.). Democratizar a democracia: os caminhos da democracia participativa. Coleção Reinventar a emancipação social: para novos manifestos. Vol. 01. Rio de Janeiro: Civilização Brasileira, 2002. 
59. SERVA, Leão. Jornalismo e Desinformação. 2a ed. São Paulo: Senac, 2001.

60. SOARES, Maria Victoria de Mesquita Benevides. Cidadania e Direitos Humanos. IN: Cadernos de Pesquisa. № 104. São Paulo: Fundação Carlos Chagas, 1998. p. 39-46.

61. SODRÉ, Nelson Werneck. História da imprensa no Brasil. 3ạ ed. São Paulo: Martins Fontes, 1983.

62. STEINBERG, Charles (org.). Meios de comunicação de massa. São Paulo: Cultrix, 1966.

63. TOMMASI, Lívia de e outros (org.). O Banco Mundial e as políticas educacionais. 3ạ ed. São Paulo: Cortez, 2000.

64. TRAQUINA, Nelson. O Estudo do Jornalismo no Século XX. São Leopoldo: Unisinos, 2003.

65. VERÍSSIMO, Luís Fernando e outros. O desafio ético. Rio de Janeiro: Garamond, 2000.

66. WOOD, Ellen Meiksins. Democracia contra capitalismo: a renovação do materialismo histórico. Tradução de Paulo Cezar Castenheira. São Paulo: Boitempo, 2003.

67. WOLF, Mauro. Teorias da Comunicação. Lisboa: Editorial Presença, 1994. 


\section{Referências normativas}

68. NORONHA, Dayse Pires (org.). Manual para apresentação de dissertações e teses. São Paulo, 2003. Escola de Comunicações e Artes, Universidade de São Paulo

69. SEVERINO, Antônio Joaquim. Metodologia do trabalho científico. 21a ed. São Paulo: Cortez, 2000.

\section{Teses}

70. LAURENTI, Maria Elisabete Antonelli. Liberdade curricular nos cursos de Jornalismo: a responsabilidade e o desafio da formação profissional. São Paulo, 2002. Tese (Doutorado) - Escola de Comunicações e Artes, Universidade de São Paulo.

71. RAMADAN, Nancy N. Ali. J ornalismo na era digital: construindo uma filosofia de ensino. São Paulo, 2000. Tese (Doutorado) - Escola de Comunicações e Artes, Universidade de São Paulo.

\section{Dissertações}

72. AROUCA, Lucila S. Fundamentos fenomenológico - existenciais da comunicação professor - aluno na teoria da educação de Carl R. Rogers. São Paulo, 1977. Dissertação (Mestrado) - Faculdade de Educação, Universidade de São Paulo.

73. HASWANI, Mariângela F. Quem agenda quem: estudo das relações entre assessorias de imprensa do setor público e veículos jornalísticos na cidade de São Paulo. São Paulo, 2004. Dissertação (Mestrado) Escola de Comunicações e Artes, Universidade de São Paulo. 


\section{Monografias}

74. COSTA, Rílmane Rose Simões de A.; MORAES Jr., Enio. A comunicação não-verbal através dos movimentos corporais. Maceió, 1993. Trabalho de Conclusão de Curso - Universidade Federal de Alagoas, Maceió.

\section{Periódicos}

75. AGUIAR, Sônia. Repensando o ensino da comunicação. Cadernos IACS, Vol. 05. Niterói: Instituto de Arte e Comunicação Social / UFF, 1999, p. 03-66.

76. CATTANI, Afrânio Mendes; OLIVEIRA, João Ferreira de. A reestruturação da educação superior no debate internacional: a padronização das políticas de diversificação. Caderno Universidade e Sociedade. Vol. 10. № 21. Brasília: ANDES, janeiro / abril de 2000. p. 92-101.

77. LOPES, Dirceu Fernandes. Para uma pedagogia do jornallaboratório. Cadernos Posgrad. Unisantos: Santos, 2001.

78. MARCOS, Eduardo Rocha. O discurso da cidadania no telejornal SPTV. Revista Thésis. Ano III, № 06. São Paulo: Faculdade de Comunicação Cásper Líbero, 1o semestre de 2002. p. 46-48.

79. MORAES J r., Enio. Formação Profissional e Perfil do Jornalista no Mercado de Trabalho: artigo. IN: Revista Nexos, Ano VII, № 10 (ISSN 1415-3610). São Paulo: Editora Anhembi Morumbi, 2003. p. 07-21. 
80. PALMA FILHO, J oão Cardoso. Cidadania e educação. IN: Cadernos de Pesquisa. № 104. São Paulo: Fundação Carlos Chagas, 1998. p. 101-121.

81. PEUCER, Tobias. Os relatos jornalísticos. IN: Revista Comunicação e Sociedade. № 33. São Bernardo do Campo: Umesp, 2000. p. 199214.

\section{J ornais}

82. FAVERO, Thomaz. Novos alunos pensam prós e contras da universidade. Jornal do Campus. ECA: USP. Ano 22, edição 281. São Paulo: 1 o a 21 de abril de 2004. p. 02.

83. GREENALGH, Laura. Então, instaure-se a moralidade. (Entrevista com José Murilo de Carvalho). O Estado de S. Paulo. São Paulo: 22 de maio de 2005. p. J4-J5.

84. MORAES J r., Enio. Obrigatoriedade de Formação não fere Liberdade de Expressão. Jornal da Cidade, Ano XXX, no 9.202. Aracaju: 05 de novembro de 2001.

85. Ombudsman: apresentação. Jornal do Campus. ECA: USP. Ano 22, edição 281. São Paulo: 1o a 21 de abril de 2004. p. 03.

86. Jornal do Campus. ECA: USP. Ano 24, edição 303. São Paulo: segunda quinzena de outubro de 2005.

87. SOARES, Rosana de Lima. O jornalismo e a lógica dos conflitos. Jornal do Campus. ECA: USP. Ano 22, edição 282. São Paulo: 22 de abril a 05 de maio de 2004. p. 02. 
88. - Persuadir, convencer, demonstrar. Jornal do Campus. ECA: USP. Ano 22, edição 283. São Paulo: 06 a 19 de maio de 2004. p. 03.

89. . Estigmas, estereótipos, preconceitos: bifurcações. Jornal do Campus. ECA: USP. Ano 22, edição 284. São Paulo: 21 de maio a 03 de junho de 2004. p. 02.

90. . Jornalismo e referencialidade: números demais?. Jornal do campus. ECA: USP. Ano 22, edição 285. São Paulo: 04 a 17 de junho de 2004. p. 02.

91. . Redundâncias, ressonâncias. Jornal do Campus. ECA: USP. Ano 22, edição 286. São Paulo: 25 de junho a 09 de julho de 2004.

\section{Revistas}

92. LAGE, Nilson. A briga pelo novo currículo. In: Revista da Comunicação. Ano I, №. 02. Rio de Janeiro: Agora Comunicação, 1985.

93. ACCARDO, Allan. A liberdade de fazer como se deve. Revista Caros Amigos, São Paulo: Editora Casa Amarela. Ano IV, № 39, junho de 2002, p. 43-44.

\section{Material apostilado}

94. COELHO SOBRINHO, José. A crise dos paradigmas educacionais: pedagogia e didática. Material apostilado: Pedagogia e didática aplicadas ao ensino do jornalismo. Programa de pós-graduação da 
Escola de Comunicações e Artes. Universidade de São Paulo. São Paulo: 2002.

95. . Objetivo, justificativa e objeto. Material apostilado: Metodologia científica aplicada ao jornalismo. Programa de pósgraduação da Escola de Comunicações e Artes. Universidade de São Paulo. São Paulo: 2002.

96. MARQUES DE MELO, José; VIANNA, Ruth. Raízes Forâneas do Pensamento Jornalístico Brasileiro. Material apostilado: Pensamento jornalístico brasileiro. Programa de pós-graduação da Escola de Comunicações e Artes. Universidade de São Paulo. São Paulo: 2003.

97. RAMADAN, Nancy N. Ali. Da educação, ensino, pedagogia, didática. Material apostilado: Jornalismo: perspectivas para a prática e para o ensino. Programa de pós-graduação da Escola de Comunicações e Artes. Universidade de São Paulo. São Paulo: 2003.

\section{Sites consultados / Textos retirados da internet}

98. BRASIL. Plano Nacional de Graduação. Brasília: MEC. Disponível em: <http://www.mec.gov.br/png>. Acesso em: 21 de outubro de 2002.

99. BRUDER, Carsten. Forças e esforços: a criação do Departamento de jornalismo na ECA-USP. Disponível em: http://www.eca.usp.br/prof/josemarques/arquivos/ensaios2_f.htm. Acesso em 20 de setembro de 2004.

100. CAMPOS, Pedro Celso. Jornalismo Digital: novos paradigmas da produção, recepção e difusão do discurso. 2001. Disponível em: 
http://observatorio.ultimosegundo.ig.com. br/artigos/da311020014p.ht m. Acesso em 26 de maio de 2003.

101. ChAPARRO, Manuel Carlos. A difícil tarefa de fazer jornalistas. Comunique-se, 05 de outubro de 2005. Disponível em: <http://www.comuniquese.com.br>. Acesso em: 11 de outubro de 2005.

102. Sociedade, razão de ser do Jornalismo. Comunique-se, 25 de junho de 2003. Disponível em: <http://www. comuniquese.com.br>. Acesso em: 30 de junho de 2003.

103. Código de Ética dos Jornalistas Brasileiros. In: Federação Nacional dos Jornalistas do Brasil. Brasília: FENAJ. Disponível em: <http://www.fenaj.org.br/leis.php?id=21>. Acesso em: 24 de outubro de 2005.

104. COMPARATO, Fábio Konder. O Sentido Histórico da Declaração Universal. IN: DHnet: Rede Brasil de Direitos Humanos. <http://www.dhnet.org.br/direitos/deconu/textos/konder.htm>. Acesso em 25 de outubro de 2005.

105. Declaração Universal dos Direitos Humanos. In: Rede Brasil de Direitos Humanos (Dhnet). <http://www.dhnet. org. br/direitos/deconu/textos/integra. htm\#30>. Acesso em 25 de outubro de 2005.

106. ECA: USP. Núcleos de Pesquisa. Disponível em: http://www.eca.usp. br/pesquisa/nuclpesq/nucleo.htm\#cje. Acessado em 20 de maio de 2005. 
107. ECA: USP. Organização departamental. Disponível em: http://www.eca.usp.br/organiza/departam/. Acesso em 20 de maio de 2005.

108. ECA: USP. Serviço de Biblioteca e Documentação. Disponível em: http://www.rebeca.eca.usp.br/. Acesso em 27 de abril de 2005.

109. KOSHIYAMA, Alice Mitika. A prática política para ser jornalista ECA / USP 1975 - 1976. ECA, [s.d.]. Disponível em: www.eca.usp.br/prof/josemarques/arquivos/23k03.PDF.pdf Acesso em: 23 de junho de 2005.

110. KUCINSKY, Bernardo. Uma nova ética para uma nova modernidade. Observatório da Imprensa, 24 de abril de 2004. Disponível em: $<\mathrm{http}: / / \mathrm{www}$. observatoriodaimprensa.com. br/artigo/da010520021.htm>. Acesso em: 03 de maio de 2004.

111. MORAES Jr., Enio; MOREIRA, Júlio Antônio. Frei Caneca, um argonauta no jornalismo Brasileiro. São Paulo: Rede Alfredo de Carvalho, 2004.2 Disponível em: <http://www2.metodista.br/unesco/hp_unesco_redealcar36completo.ht $m$ >. Acesso em: 28 de março de 2004.

112. USP (Universidade de São Paulo). Anuário Estatístico 2004. 2005 Disponível em: http://www2.usp. br/portugues/conteudo. php?dir=/ausp/infogeral/USPe mnumeros.htm. Acesso em: 10 de julho de 2005. 
113. USP (Universidade de São Paulo). Sistema Rebeca. 2005. Disponível em http://www.rebeca.eca.usp.br/. Acesso em: 20 de maio de 2005.

114. VIANNA, Ruth. Editorial. Mural do Pensamento Jornalístico Brasileiro. Ano I, № 02 . Disponível em: http://www.eca.usp.br/pjbr/arquivos/editorial2.htm. Acesso em: 18 de janeiro de 2005.

\section{Fontes eletrônicas / Entrevistas}

115. BARTLEY, Kim; O'BRIAM, Donnacha. A Revolução Não Será Televisionada. Irlanda / Venezuela, 2002. 70 min. 01 DVD.

116. BIANCHI, Sérgio (dir). Cronicamente Inviável. Brasil, 2000. 102 min. 01 DVD.

117. BUCCI, Eugênio. Eugênio Bucci: entrevista [nov. 2002]. Entrevistador: Enio Moraes Júnior. São Paulo: ECA / USP, 2002. 1 fita cassetes (60 min), 3 1/4 pps, estéreo. Entrevista concedida à revista Nexos.

118. COELHO SOBRINHO, José. José Coelho Sobrinho: entrevista [mai. 2003]. Entrevistador: Enio Moraes Júnior. São Paulo: ECA / USP, 2003. 1 fita cassetes ( $60 \mathrm{~min}$ ), 3 1/4 pps, estéreo. Entrevista concedida ao site Mural do Pensamento Jornalístico Brasileiro.

119. FERNANDES, Adélia Barroso. Jornalismo, cidadania e direitos humanos: uma relação reflexiva no espaço público. Salvador: XXV Intercom, 2002. 1 CD-ROM. 
120. GRAVAS, Costa (dir). O Quarto Poder. EUA, 1997. 115 min. 01 DVD.

121. MANN, Michael (dir). O Informante. EUA, 1999. 157 min. 01 DVD.

122. SOMMA NETO, João. Jornalismo, informação e cidadania Contemporânea. Salvador: XXV Intercom, 2002. 1 CD-ROM.

\section{Legislação}

123. BRASIL. Constituição da República Federativa do Brasil. [s. ed.] São Paulo: Ática, 1990.

\section{Relatórios e cadastros}

124. ECA: USP. Balaço de uma gestão ECA - USP: 1989 - 1992. São Paulo: ECA / USP, 1992.

125. ECA: USP. Cadastro Predial da Escola de Comunicações e Artes. Folha 01. Coordenadoria do Espaço Físico da USP. São Paulo, abril de 2005. 


\section{Apêndice 01}

Relação bibliográfica dos jornais-laboratório

- Jornal do Campus -

referenciados nesta dissertação 
1. Jornal do Campus. ECA: USP. Ano 22, edição 281. São Paulo: 1ำ a 21 de abril de 2004.

2. Jornal do Campus. ECA: USP. Ano 22, edição 282. São Paulo: 22 de abril a 05 de maio de 2004.

3. Jornal do Campus. ECA: USP. Ano 22, edição 283. São Paulo: 06 a 19 de maio de 2004.

4. Jornal do Campus. ECA: USP. Ano 22, edição 284. São Paulo: 21 de maio a 03 de junho de 2004.

5. Jornal do Campus. ECA: USP. Ano 22, edição 284 - Especial. São Paulo: 21 de maio a 03 de junho de 2004.

6. Jornal do Campus. ECA: USP. Ano 22, edição 285. São Paulo: 04 a 17 de junho de 2004.

7. Jornal do Campus. ECA: USP. Ano 22, edição 286. São Paulo: 25 de junho a 09 de julho de 2004. 


\author{
Apêndice 02 \\ Relação bibliográfica dos TCCs \\ do curso de Jornalismo noturno da ECA 2002-2003 \\ referenciados nesta dissertação
}




\section{Trabalhos de Conclusão de Curso $-2002^{58}$}

1. ALVES, Tomaz Rodrigo. Artilheiro é quem decide: os goleadores mais importantes das eliminatórias e da Copa do Mundo 2002. São Paulo, 2002. 46 p. Trabalho de Conclusão de Curso. Escola de Comunicações e Artes, Universidade de São Paulo. São Paulo.

2. BRITO, Carolina Fantaccini. Literatura feminina: retratos do imaginário. São Paulo, 2002. 48 p. Trabalho de Conclusão de Curso. Escola de Comunicações e Artes, Universidade de São Paulo. São Paulo.

3. CARMO, Cely da Silva. Grandes mestres da ciência brasileira: André Dreyfus (1897-1952). São Paulo, 2002. 24 p. Trabalho de Conclusão de Curso. Escola de Comunicações e Artes, Universidade de São Paulo. São Paulo.

4. CHIQUETA, Nádia Borba Mulheres e grades. São Paulo, 2002. 1 v. Trabalho de Conclusão de Curso. Escola de Comunicações e Artes, Universidade de São Paulo. São Paulo.

5. FARIA, Márcio Tucunduva de. Adolescência positiva: documentário sobre adolescentes HIV positivos de transmissão vertical. São Paulo, 2002. 21 p. Trabalho de Conclusão de Curso. Escola de Comunicações e Artes, Universidade de São Paulo. São Paulo.

6. FARIAS, Adriana Fernandes. Reforma Psiquiátrica no Brasil: um caminho a percorrer. São Paulo, 2002. 73 p. Trabalho de Conclusão de Curso. Escola de Comunicações e Artes, Universidade de São Paulo. São Paulo.

\footnotetext{
${ }^{58}$ A relação de trabalhos de conclusão de curso apresentada refere-se àqueles que haviam sido depositados na biblioteca até o fechamento desta fase da pesquisa: abril de 2005.
} 
7. GARCIA, Rafael Fontana. A universidade no caminho da exclusão social. São Paulo, 2002. 24 p. Trabalho de Conclusão de Curso. Escola de Comunicações e Artes, Universidade de São Paulo. São Paulo.

8. GIANNECCHINI, Laura Mariana. Revista Dois Pontos. São Paulo, 2002. 50 p. Trabalho de Conclusão de Curso. Escola de Comunicações e Artes, Universidade de São Paulo. São Paulo.

9. GRIZZO FILHO, Arnaldo. Sobre o Atlântico: reportagem-ensaio sobre o reide aéreo, através do Oceano Atlântico, realizado pelo aviador jauense João Ribeiro de Barros em 1927. São Paulo, 2002. 43 p. Trabalho de Conclusão de Curso. Escola de Comunicações e Artes, Universidade de São Paulo. São Paulo.

10. GOBBET, Cassiano Ricardo. Por que a gente é assim: um passeio pela cultura que tempera o futebol brasileiro. São Paulo, 2002. 71 p. Trabalho de Conclusão de Curso. Escola de Comunicações e Artes, Universidade de São Paulo. São Paulo.

11. KAMEOKA, Marcio. Fome no Brasil: caminhos trilhados e a distância por percorrer. São Paulo, 2002. 82 p. Trabalho de Conclusão de Curso. Escola de Comunicações e Artes, Universidade de São Paulo. São Paulo.

12. LEITE, Andrea Limberto. O encantamento da serpente: sensualidade na dança do ventre. São Paulo, 2002. 55 p. Trabalho de Conclusão de Curso. Escola de Comunicações e Artes, Universidade de São Paulo. São Paulo. 
13. LONEEFF, Daniel. Ensaio reportagem: a revolução silenciosa: o impacto da tecnologia da informação sobre a base tecnoprodutiva e a gestão empresarial. São Paulo, 2002. 121 p. Trabalho de Conclusão de Curso. Escola de Comunicações e Artes, Universidade de São Paulo. São Paulo.

14. MATUSHITA, Joana Mitsuyo. Passagens: a história de Ney Bourroul. São Paulo, 2002. 74 p. Trabalho de Conclusão de Curso. Escola de Comunicações e Artes, Universidade de São Paulo. São Paulo.

15. MUSOLINO, Larissa Purvinis. Fuzilando na Barão de Limeira : depoimentos de jornalistas que testemunharam vida e morte do Notícias Populares. São Paulo, 2002. 116 p. Trabalho de Conclusão de Curso. Escola de Comunicações e Artes, Universidade de São Paulo. São Paulo.

16. NEVES, Lidia Gurgel. Classes populares no jornalismo: uma análise dos estigmas sob a ótica da esfera pública. São Paulo, 2002. 83 p. Trabalho de Conclusão de Curso. Escola de Comunicações e Artes, Universidade de São Paulo. São Paulo.

17. NUNES, Angela Ribeiro. São Paulo verso e reverso: o fascínio do centro histórico. São Paulo, 2002. 54 p. Trabalho de Conclusão de Curso. Escola de Comunicações e Artes, Universidade de São Paulo. São Paulo.

18. PIZA, André Sigrist de Toledo. Digitalização no cinema. São Paulo, 2002. 56 p. Trabalho de Conclusão de Curso. Escola de Comunicações e Artes, Universidade de São Paulo. São Paulo. 
19. RICIERI, Daniele Prandini. A crítica teatral e sua inserção na indústria cultural. São Paulo, 2002. 48 p. Trabalho de Conclusão de Curso. Escola de Comunicações e Artes, Universidade de São Paulo. São Paulo.

20. SAITO, Ana Carolina. Ensaio sobre a opinião pública política : Kant segundo Hannah Arendt. São Paulo, 2002. 84 p. Trabalho de Conclusão de Curso. Escola de Comunicações e Artes, Universidade de São Paulo. São Paulo.

21. SEMENOV, Alethea Rodrigues. Turismo ambiental no Pantanal norte: pelos caminhos da transpantaneira. São Paulo, 2002. 24 p. Trabalho de Conclusão de Curso. Escola de Comunicações e Artes, Universidade de São Paulo. São Paulo.

22. SILVA JR, Aduil Roberto da. Revolução Constitucionalista de 32: a guerra de São Paulo. São Paulo, 2002. 8 p. Trabalho de Conclusão de Curso. Escola de Comunicações e Artes, Universidade de São Paulo. São Paulo.

23. TARGA, Renato Simões. Gerencie seu estresse ou fique doente. São Paulo, 2002. 16 p. Trabalho de Conclusão de Curso. Escola de Comunicações e Artes, Universidade de São Paulo. São Paulo.

24. VAZ, Ana Carolina Rocha. Jornalismo de celebridades: passaporte para um mundo de sonho. São Paulo, 2002. 64 p. Trabalho de Conclusão de Curso. Escola de Comunicações e Artes, Universidade de São Paulo. São Paulo.

25. VIEIRA, Marina Motomura Gonçalves. A vida no arame. São Paulo, 2002. 74 p. Trabalho de Conclusão de Curso. Escola de Comunicações e Artes, Universidade de São Paulo. São Paulo. 


\section{Trabalhos de Conclusão de Curso - 2003}

26. ALMEIDA, Thaís Yuri Tanaka de. A vida sobre rodas. São Paulo, 2003. 16 p. Trabalho de Conclusão de Curso. Escola de Comunicações e Artes, Universidade de São Paulo. São Paulo.

27. ANDRADE, Ana Paula Ziglio de. Somos franceses: como vivem os ciganos na França do século XXI. São Paulo, 2003. 196 p. Trabalho de Conclusão de Curso. Escola de Comunicações e Artes, Universidade de São Paulo. São Paulo.

28. BERNDT, Ana Lúcia. A visão da mídia sobre a medicina complementar. São Paulo, 2003. Trabalho de Conclusão de Curso. Escola de Comunicações e Artes, Universidade de São Paulo. São Paulo.

29. BRAZ, Felipe Carion. A construção do estereótipo do sucesso profissional em revistas de negócio especializadas. São Paulo, 2003. Trabalho de Conclusão de Curso. Escola de Comunicações e Artes, Universidade de São Paulo. São Paulo.

30. CAPAl, Eliza Ribeiro. Vertigem. São Paulo, 2003. 1 v. il. Trabalho de Conclusão de Curso. Escola de Comunicações e Artes, Universidade de São Paulo. São Paulo.

31. COSTAS, Ruth Pinheiro. A guerra na TV: uma análise da cobertura da Guerra no Iraque em 2003. São Paulo, 2003. 63 p. Trabalho de Conclusão de Curso. Escola de Comunicações e Artes, Universidade de São Paulo. São Paulo.

32. FARNESI, Luciana Vasques. O Brasil e a reforma do Conselho de Segurança da Nações Unidas. São Paulo, 2003. 92 p. Trabalho de 
Conclusão de Curso. Escola de Comunicações e Artes, Universidade de São Paulo. São Paulo.

33. FIGUEIREDO, Marcy Picanço. Querido diário: um estudo sobre a edição de diários íntimos no Brasil. São Paulo, 2003. 70 p. Trabalho de Conclusão de Curso. Escola de Comunicações e Artes, Universidade de São Paulo. São Paulo.

34. GANANIAN, Julienne. Introdução à história da fotografia de imprensa no Brasil: 1920-1945. São Paulo, 2003. 118 p. Trabalho de Conclusão de Curso. Escola de Comunicações e Artes, Universidade de São Paulo. São Paulo.

35. GOMES FILHO, Jacques. You are welcome! : a influência da brasilidade no trabalho de correspondência jornalística internacional. São Paulo, 2003. 117 p. Trabalho de Conclusão de Curso. Escola de Comunicações e Artes, Universidade de São Paulo. São Paulo.

36. GONZALEZ, Maria Martins. Título: As donas da casa: três mulheres na luta por moradia em São Paulo. São Paulo, 2003. 139 p. Trabalho de Conclusão de Curso. Escola de Comunicações e Artes, Universidade de São Paulo. São Paulo.

37. IWAKURA, Mariana. Título: Horizontes: terceira idade e o lazer como sua principal atividade. São Paulo, 2003. 27 p. Trabalho de Conclusão de Curso. Escola de Comunicações e Artes, Universidade de São Paulo. São Paulo.

38. LANGNER, Christopher David Sanson. Forbes Brasil: o fim da essência do capitalismo. São Paulo, 2003. 93 p. Trabalho de Conclusão de Curso. Escola de Comunicações e Artes, Universidade de São Paulo. São Paulo. 
39. MASSAD, Anselmo Merichelli. Fontes de informação: as fontes ouvidas nas revistas semanais. São Paulo, 2003. Trabalho de Conclusão de Curso. Escola de Comunicações e Artes, Universidade de São Paulo. São Paulo.

40. MEDEIROS, Leonardo. Conexão Ciência: um projeto televisivo para a divulgação da produção científica nacional. São Paulo, 2003. 115 p. Trabalho de Conclusão de Curso. Escola de Comunicações e Artes, Universidade de São Paulo. São Paulo.

41. MELLO, Fernando Ferrari de Almeida. A Era Teixeira. São Paulo, 2003. 225 p. Trabalho de Conclusão de Curso. Escola de Comunicações e Artes, Universidade de São Paulo. São Paulo.

42. MIÓLI, Júlia Bruno. Borges, o repórter imaginário. São Paulo, 2003. Trabalho de Conclusão de Curso. Escola de Comunicações e Artes, Universidade de São Paulo. São Paulo.

43. MONTEIRO, Carolina de Araújo. O enfermeiro do inferno. São Paulo, 2003. 137 p. Trabalho de Conclusão de Curso. Escola de Comunicações e Artes, Universidade de São Paulo. São Paulo.

44. MULLER, Rafaela G. Giratempo: Cultura caipira e novos significados para a tradição. São Paulo, 2003. Trabalho de Conclusão de Curso. Escola de Comunicações e Artes, Universidade de São Paulo. São Paulo.

45. NAIME, Laura de Carvalho. São Paulo sobre trilhos. São Paulo, 2003. 125 p. Trabalho de Conclusão de Curso. Escola de Comunicações e Artes, Universidade de São Paulo. São Paulo. 
46. PASSOS FILHO, Saulo Duarte. Gerenciamento de crises : seus modelos, casos e o papel da assessoria de comunicação. São Paulo, 2003. 62 p. Trabalho de Conclusão de Curso. Escola de Comunicações e Artes, Universidade de São Paulo. São Paulo.

47. PEDROSO, Fábio Luís. Prisão : uma tecnologia defasada. São Paulo, 2003. 72 p. Trabalho de Conclusão de Curso. Escola de Comunicações e Artes, Universidade de São Paulo. São Paulo.

48. PRUDENTE, Gustavo Barreto. Sopa de pizza : histórias de gente diferente. São Paulo, 2003. 167 p. Trabalho de Conclusão de Curso. Escola de Comunicações e Artes, Universidade de São Paulo. São Paulo.

49. SALLA, Thiago Mio. Crônica: jornalismo em Graciliano Ramos. São Paulo, 2003. 102 p. Trabalho de Conclusão de Curso. Escola de Comunicações e Artes, Universidade de São Paulo. São Paulo.

50. SCHOR, Gustavo. A tenacidade de genes e sonhos: os 50 anos do Hospital do Câncer. São Paulo, 2003. 153 p. Trabalho de Conclusão de Curso. Escola de Comunicações e Artes, Universidade de São Paulo. São Paulo.

51. SOUZA JR, Luís Roberto de. Hemingway e Hadley em Paris: os caminhos para se tornar um escritor nos anos 20. São Paulo, 2003. 60 p. Trabalho de Conclusão de Curso. Escola de Comunicações e Artes, Universidade de São Paulo. São Paulo.

52. UEMURA, Tatiana. Terceiro Setor: uma proposta de um suplemento para o jornal Folha de S Paulo. São Paulo, 2003. 46 p. Trabalho de Conclusão de Curso. Escola de Comunicações e Artes, Universidade de São Paulo. São Paulo. 
53. VEZZALI, Fabiana. Do mesmo lado do balcão: as relações entre jornalistas e assessores de imprensa. São Paulo, 2003. 98 p. Trabalho de Conclusão de Curso. Escola de Comunicações e Artes, Universidade de São Paulo. São Paulo.

54. WEBER, Mariana Bittencourt. Alerta vermelho: o cotidiano do resgate na cidade de São Paulo. São Paulo, 2003. 61 p. Trabalho de Conclusão de Curso. Escola de Comunicações e Artes, Universidade de São Paulo. São Paulo.

55. YAMAMOTO, Érika. Retrato fotográfico: de objeto particular a imagem coletiva. São Paulo, 2003. 103 p. Trabalho de Conclusão de Curso. Escola de Comunicações e Artes, Universidade de São Paulo. São Paulo. 


\section{Anexo 01}

Declaração Universal dos Direitos Humanos 


\title{
Declaração Universal dos Direitos Humanos
}

\author{
Adotada e proclamada pela resolução 217 A (III) \\ da Assembléia Geral das Nações Unidas em 10 de \\ dezembro de 1948
}

\section{Preâmbulo}

CONSIDERANDO que o reconhecimento da dignidade inerente a todos os membros da família humana e seus direitos iguais e inalienáveis é o fundamento da liberdade, da justiça e da paz no mundo, CONSIDERANDO que o desprezo e o desrespeito pelos direitos do homem resultaram em atos bárbaros que ultrajaram a consciência da Humanidade, e que o advento de um mundo em que os homens gozem de liberdade de palavra, de crença e da liberdade de viverem a salvo do temor e da necessidade, CONSIDERANDO ser essencial que os direitos do homem sejam protegidos pelo império da lei, para que o homem não seja compelido, como último recurso, à rebelião contra a tirania e a opressão, CONSIDERANDO ser essencial promover o desenvolvimento de relações amistosas entre as nações, CONSIDERANDO que os povos das Nações Unidas reafirmaram, na Carta, sua fé nos direitos do homem e da mulher, e que decidiram promover o progresso social e melhores condições de vida em uma liberdade mais ampla, CONSIDERANDO que os Estados Membros se comprometeram a promover, em cooperação com as Nações Unidas, o respeito universal aos direitos e liberdades fundamentais do homem e a observância desses direitos e liberdades, CONSIDERANDO que uma compreensão comum desses direitos e liberdades é da mais alta importância para o pleno cumprimento desse compromisso,

A Assembléia Geral das Nações Unidas proclama a presente "Declaração Universal dos Direitos do Homem" como o ideal comum a ser atingido por todos os povos e todas as nações, com o objetivo de que cada indivíduo e cada órgão da sociedade, tendo sempre em mente esta Declaração, se esforce, através do ensino e da educação, por promover o respeito a esses direitos e liberdades, e, pela adoção de medidas progressivas de caráter nacional e internacional, por assegurar o seu reconhecimento e a sua observância universais e efetivos, tanto entre os povos dos próprios Estados Membros, quanto entre os povos dos territórios sob sua jurisdição.

\section{Artigo I}

Todos os homens nascem livres e iguais em dignidade e direitos. São dotados de razão e consciência e devem agir em relação uns aos outros com espírito de fraternidade.

\section{Artigo II}

I) Todo o homem tem capacidade para gozar os direitos e as liberdades estabelecidos nesta Declaração sem distinção de qualquer espécie, seja de raça, cor, sexo, língua, religião, opinião política ou de outra natureza, origem nacional ou social, riqueza, nascimento, ou qualquer outra condição. 
II) Não será também feita nenhuma distinção fundada na condição política, jurídica ou internacional do país ou território a que pertença uma pessoa, quer se trate de um território independente, sob tutela, sem governo próprio, quer sujeito a qualquer outra limitação de soberania.

Artigo III

Todo o homem tem direito à vida, à liberdade e à segurança pessoal.

Artigo IV

Ninguém será mantido em escravidão ou servidão; a escravidão e o tráfico de escravos estão proibidos em todas as suas formas.

Artigo $\mathrm{V}$

Ninguém será submetido a tortura, nem a tratamento ou castigo cruel, desumano ou degradante.

Artigo VI

Todo homem tem o direito de ser, em todos os lugares, reconhecido como pessoa perante a lei.

Artigo VII

Todos são iguais perante a lei e tem direito, sem qualquer distinção, a igual proteção da lei. Todos têm direito a igual proteção contra qualquer discriminação que viole a presente Declaração e contra qualquer incitamento a tal discriminação.

Artigo VIII

Todo o homem tem direito a receber dos tribunais nacionais competentes remédio efetivo para os atos que violem os direitos fundamentais que the sejam reconhecidos pela constituição ou pela lei.

Artigo IX

Ninguém será arbitrariamente preso, detido ou exilado.

Artigo $X$

Todo o homem tem direito, em plena igualdade, a uma justa e pública audiência por parte de um tribunal independente e imparcial, para decidir de seus direitos e deveres ou do fundamento de qualquer acusação criminal contra ele.

Artigo XI

I) Todo o homem acusado de um ato delituoso tem o direito de ser presumido inocente até que a sua culpabilidade tenha sido provada de acordo com a lei, em julgamento público no qual lhe tenham sido asseguradas todas as garantias necessárias a sua defesa.

II) Ninguém poderá ser culpado por qualquer ação ou omissão que, no momento, não constitua delito perante o direito nacional ou internacional. Também não será imposta pena mais forte do que aquela que, no momento da prática, era aplicável ao ato delituoso. 


\section{Artigo XII}

Ninguém será sujeito a interferências na sua vida privada, na sua família, no seu lar ou na sua correspondência, nem a ataques a sua honra e reputação. Todo o homem tem direito à proteção da lei contra tais interferências ou ataques.

\section{Artigo XIII}

I) Todo homem tem direito à liberdade de locomoção e residência dentro das fronteiras de cada Estado.

II) Todo o homem tem o direito de deixar qualquer país, inclusive o próprio, e a este regressar.

\section{Artigo XIV}

I) Todo o homem, vítima de perseguição, tem o direito de procurar e de gozar asilo em outros países.

II) Este direito não pode ser invocado em casos de perseguição legitimamente motivada por crimes de direito comum ou por atos contrários aos objetivos e princípios das Nações Unidas.

\section{Artigo XV}

I) Todo homem tem direito a uma nacionalidade.

II) Ninguém será arbitrariamente privado de sua nacionalidade, nem do direito de mudar de nacionalidade.

Artigo XVI

I) Os homens e mulheres de maior idade, sem qualquer restrição de raça, nacionalidade ou religião, tem o direito de contrair matrimônio e fundar uma família. Gozam de iguais direitos em relação ao casamento, sua duração e sua dissolução.

II) O casamento não será válido senão com o livre e pleno consentimento dos nubentes.

III) A família é o núcleo natural e fundamental da sociedade e tem direito à proteção da sociedade e do Estado.

\section{Artigo XVII}

I) Todo o homem tem direito à propriedade, só ou em sociedade com outros.

II) Ninguém será arbitrariamente privado de sua propriedade.

\section{Artigo XVIII}

Todo o homem tem direito à liberdade de pensamento, consciência e religião; este direito inclui a liberdade de mudar de religião ou crença e a liberdade de manifestar essa religião ou crença, pelo ensino, pela prática, pelo culto e pela observância, isolada ou coletivamente, em público ou em particular.

\section{Artigo XIX}

Todo o homem tem direito à liberdade de opinião e expressão; este direito inclui a liberdade de, sem interferências, ter opiniões e de procurar, receber e transmitir informações e idéias por quaisquer meios, independentemente de fronteiras. 
Artigo XX

I) Todo o homem tem direito à liberdade de reunião e associação pacíficas.

II) Ninguém pode ser obrigado a fazer parte de uma associação.

\section{Artigo XXI}

I) Todo o homem tem o direito de tomar parte no governo de seu país diretamente ou por intermédio de representantes livremente escolhidos.

II) Todo o homem tem igual direito de acesso ao serviço público do seu país.

III) A vontade do povo será a base da autoridade do governo; esta vontade será expressa em eleições periódicas e legítimas, por sufrágio universal, por voto secreto ou processo equivalente que assegure a liberdade de voto.

\section{Artigo XXII}

Todo o homem, como membro da sociedade, tem direito à segurança social e à realização, pelo esforço nacional, pela cooperação internacional e de acordo com a organização e recursos de cada Estado, dos direitos econômicos, sociais e culturais indispensáveis à sua dignidade e ao livre desenvolvimento de sua personalidade.

\section{Artigo XXIII}

I) Todo o homem tem direito ao trabalho, à livre escolha de emprego, a condições justas e favoráveis de trabalho e à proteção contra o desemprego.

II) Todo o homem, sem qualquer distinção, tem direito a igual remuneração por igual trabalho.

III) Todo o homem que trabalha tem direito a uma remuneração justa e satisfatória, que lhe assegure, assim como a sua família, uma existência compatível com a dignidade humana, e a que se acrescentarão, se necessário, outros meios de proteção social.

IV) Todo o homem tem direito a organizar sindicatos e a neles ingressar para proteção de seus interesses.

\section{Artigo XXIV}

Todo o homem tem direito a repouso e lazer, inclusive a limitação razoável das horas de trabalho e a férias remuneradas periódicas.

\section{Artigo XXV}

I) Todo o homem tem direito a um padrão de vida capaz de assegurar a si e a sua família saúde e bem estar, inclusive alimentação, vestuário, habitação, cuidados médicos e os serviços sociais indispensáveis, e direito à segurança em caso de desemprego, doença, invalidez, viuvez, velhice ou outros casos de perda de meios de subsistência em circunstâncias fora de seu controle.

II) A maternidade e a infância têm direito a cuidados e assistência especiais. Todas as crianças, nascidas dentro ou fora do matrimônio, gozarão da mesma proteção social. 


\section{Artigo XXVI}

I) Todo o homem tem direito à instrução. A instrução será gratuita, pelo menos nos graus elementares e fundamentais. A instrução elementar será obrigatória. A instrução técnico-profissional será acessível a todos, bem como a instrução superior, esta baseada no mérito.

II) A instrução será orientada no sentido do pleno desenvolvimento da personalidade humana e do fortalecimento do respeito pelos direitos do homem e pelas liberdades fundamentais. A instrução promoverá a compreensão, a tolerância e amizade entre todas as nações e grupos raciais ou religiosos, e coadjuvará as atividades das Nações Unidas em prol da manutenção da paz.

III) Os pais têm prioridade de direito na escolha do gênero de instrução que será ministrada aos seus filhos.

\section{Artigo XXVII}

I) Todo o homem tem o direito de participar livremente da vida cultural da comunidade, de fruir as artes e de participar do progresso científico e de fruir de seus benefícios.

II) Todo o homem tem direito à proteção dos interesses morais e materiais decorrentes de qualquer produção científica, literária ou artística da qual seja autor.

\section{Artigo XXVIII}

Todo o homem tem direito a uma ordem social e internacional em que os direitos e liberdades estabelecidos na presente Declaração possam ser plenamente realizados.

\section{Artigo $\mathrm{XXIX}$}

I) Todo o homem tem deveres para com a comunidade, na qual o livre e pleno desenvolvimento de sua personalidade é possível.

II) No exercício de seus direitos e liberdades, todo o homem estará sujeito apenas às limitações determinadas pela lei, exclusivamente com o fim de assegurar o devido reconhecimento e respeito dos direitos e liberdades de outrem e de satisfazer as justas exigências da moral, da ordem pública e do bem-estar de uma sociedade democrática.

III) Esses direitos e liberdades não podem, em hipótese alguma, ser exercidos contrariamente aos objetivos e princípios das Nações Unidas.

\section{Artigo $X X X$}

Nenhuma disposição da presente Declaração pode ser interpretada como o reconhecimento a qualquer Estado, grupo ou pessoa, do direito de exercer qualquer atividade ou praticar qualquer ato destinado à destruição de quaisquer direitos e liberdades aqui estabelecidos. 


\section{Anexo 02}

Código de Ética dos Jornalistas Brasileiros 


\section{Código de Ética dos J ornalistas Brasileiros}

Votado em Congresso Nacional dos J ornalistas, o código está em vigor desde 1987.

O Código de Ética do Jornalista fixa as normas a que deverá subordinar-se a atuação do profissional, nas suas relações com a comunidade, com as fontes de informação, e entre jornalistas.

\section{I - Do direito à informação}

Art. 10 - O acesso à informação pública é um direito inerente à condição de vida em sociedade, que não pode ser impedido por nenhum tipo de interesse.

Art. 20 - A divulgação de informação, precisa e correta, é dever dos meios de comunicação pública, independente da natureza de sua propriedade.

Art. 30 - A informação divulgada pelos meios de comunicação pública se pautará pela real ocorrência dos fatos e terá por finalidade o interesse social e coletivo.

Art. 40 - A prestação de informações pelas instituições públicas, privadas e particulares, cujas atividades produzam efeito na vida em sociedade, é uma obrigação social.

Art. 50 - A obstrução direta ou indireta à livre divulgação da informação e a aplicação de censura ou autocensura são um delito contra a sociedade.

\section{II - Da conduta profissional do jornalista}

Art. 60 - O exercício da profissão de jornalista é uma atividade de natureza social e de finalidade pública, subordinado ao presente Código de Ética.

Art. 70 - O compromisso fundamental do jornalista é com a verdade dos fatos, e seu trabalho se pauta pela precisa apuração dos acontecimentos e sua correta divulgação.

Art. 80 - Sempre que considerar correto e necessário, o jornalista resguardará a origem e identidade das suas fontes de informação.

Art. 9o - É dever do jornalista:

a) Divulgar todos os fatos que sejam de interesse público.

b) Lutar pela liberdade de pensamento e expressão. 
c) Defender o livre exercício da profissão.

d) Valorizar, honrar e dignificar a profissão.

e) Opor-se ao arbítrio, ao autoritarismo e à opressão, bem como defender os princípios expressos na Declaração Universal dos Direitos do Homem.

f) Combater e denunciar todas as formas de corrupção, em especial quando exercida com o objetivo de controlar a informação.

g) Respeitar o direito à privacidade do cidadão.

h) Prestigiar as entidades representativas e democráticas da categoria.

Art. 10. O jornalista não pode:

a) Aceitar oferta de trabalho remunerado em desacordo com o piso salarial da categoria ou com a tabela fixada por sua entidade de classe.

b) Submeter-se a diretrizes contrárias à divulgação correta da informação.

c) Frustrar a manifestação de opiniões divergentes ou impedir o livre debate.

d) Concordar com a prática de perseguição ou discriminação por motivos sociais, políticos, religiosos, raciais, de sexo e de orientação sexual.

e) Exercer cobertura jornalística pelo órgão em que trabalha, em instituições públicas e privadas, onde seja funcionário, assessor ou empregado.

\section{III - Da responsabilidade profissional do jornalista}

Art. 11 - O jornalista é responsável por toda a informação que divulga, desde que seu trabalho não tenha sido alterado por terceiros.

Art. 12 - Em todos os seus direitos e responsabilidades o jornalista terá apoio e respaldo das entidades representativas da categoria.

Art. 13 - O jornalista deve evitar a divulgação de fatos:

a) Com interesse de favorecimento pessoal ou vantagens econômicas.

b) De caráter mórbido e contrários aos valores humanos.

Art. 14. O jornalista deve:

a) Ouvir sempre, antes da divulgação dos fatos, todas as pessoas objeto de acusações não comprovadas, feitas por terceiros e não suficientemente demonstradas ou verificadas. 
b) Tratar com respeito a todas as pessoas mencionadas nas informações que divulgar.

Art. 15 - O jornalista deve permitir o direito de resposta às pessoas envolvidas ou mencionadas em sua matéria, quando ficar demonstrada a existência de equívocos ou incorreções.

Art. 16. O jornalista deve pugnar pelo exercício da soberania nacional, em seus aspectos político, econômico e social, e pela prevalência da vontade da maioria da sociedade, respeitados os direitos das minorias.

Art. 17 - O jornalista deve preservar a língua e a cultura nacionais.

\section{IV - Aplicação do Código de Ética}

Art. 18 - As transgressões ao presente Código de Ética serão apuradas e apreciadas pela Comissão de Ética.

Parágrafo 10 - A Comissão de Ética será eleita em Assembléia Geral da categoria, por voto secreto, especialmente convocada para este fim.

Parágrafo 20 - A Comissão de Ética terá cinco membros com mandato coincidente com o da diretoria do Sindicato.

Art. 19 - Os jornalistas que descumprirem o presente Código de Ética ficam sujeitos gradativamente às seguintes penalidades, a serem aplicadas pela Comissão de Ética:

a) Aos associados do Sindicato, de observação, advertência, suspensão e exclusão do quadro social do Sindicato;

b) Aos não associados, de observação, advertência pública, impedimento temporário e impedimento definitivo de ingresso no quadro social do Sindicato;

Parágrafo único - As penas máximas (exclusão do quadro social, para os sindicalizados, e impedimento definitivo de ingresso no quadro social, para os não sindicalizados) só poderão ser aplicadas após prévio referendo da Assembléia Geral especialmente convocada para este fim.

Art. 20 - Por iniciativa de cidadão, jornalista ou não, ou instituição atingidos, poderá ser dirigida à Comissão de Ética para que seja apurada a existência de transgressão cometida por jornalista.

Art. 21 - Recebida a representação, a Comissão de Ética decidirá sua aceitação fundamental ou, se notadamente incabível, determinará seu arquivamento, tornando pública a decisão, se necessário.

Art. 22 - A publicação de penalidade deve ser precedida de prévia audiência do jornalista, objeto de representação, sob pena de nulidade. 
Parágrafo 10 - A audiência deve ser convocada por escrito pela Comissão de Ética, mediante sistema que comprove o recebimento da respectiva notificação, e realizar-se-á no prazo de 10 dias a contar da data do vencimento do mesmo.

Parágrafo 20 - O jornalista poderá apresentar resposta escrita no prazo do parágrafo anterior, ou apresentar suas razões oralmente, no ato da audiência.

Parágrafo 30 - A não observância pelo jornalista dos prazos previstos neste artigo, implica a aceitação dos termos da representação.

Art. 23 - Havendo ou não resposta, a Comissão de Ética encaminhará sua decisão às partes envolvidas no prazo máximo de 10 dias, contados da data marcada para a audiência.

Art. 24 - Os jornalistas atingidos pelas penas de advertência e suspensão podem recorrer à Assembléia Geral no prazo máximo de 10 dias corridos a contar do recebimento da notificação.

Parágrafo único - Fica assegurado ao autor da representação o direito de recorrer à Assembléia Geral, no prazo máximo de 10 dias a contar do recebimento a notificação, caso não concorde com a decisão da Comissão de Ética.

Art. 25 - A notória intenção de prejudicar o jornalista, manifesta em caso de representação sem o necessário fundamento, será objeto de censura pública contra o seu autor.

Art. 26 - O presente Código de Ética entrará em vigor após a homologação em Assembléia Geral de J ornalistas, especialmente convocada para este fim.

Art. 27 - Qualquer modificação neste Código somente poderá ser feita em Congresso Nacional de Jornalistas mediante proposição subscrita no mínimo por 10 delegações representantes do Sindicato de J ornalistas. 


\section{Anexos 03 a 09}

Primeiras páginas (reduzidas) dos números estudados do

Jornal do Campus - edições 281, 282, 283, 284, 284 - Especial, 285 e 286 


\section{Anexo 10}

Carta aos docentes ${ }^{59}$ encaminhada junto com questionário

${ }^{59} \mathrm{O}$ documento informava resultados preliminares da pesquisa. Alguns deles foram revistos até o seu final. 
São Paulo, 1ำ semestre de 2005

Caro (a) Professor (a),

Sou aluno concludente do mestrado em Comunicação da ECA / USP, cuja dissertação tem como título provisório A formação cidadã do jornalista no Brasil: um estudo de caso da formação do jornalista da USP. O referido estudo pretende caracterizar a formação dos discentes do curso de Comunicação Social, habilitação em Jornalismo (noturno) da ECA, no sentido de explicitar conteúdos curriculares, produções laboratoriais e etapas em função da sua formação cidadã.

O trabalho que venho desenvolvendo desde o primeiro semestre de 2003 toma como objeto formal do estudo, portanto, a cidadania (ou temas afins, como democracia, direitos humanos, responsabilidade social do jornalismo e ética profissional) e a maneira como ela aparece e é tratada na atual formação do jornalista da USP. O recorte uspiano (e ecano) deve-se ao fato de o curso de jornalismo da USP ocupar um dos espaços pioneiros no ensino da Comunicação do País e à sua notoriedade em produção acadêmica, constituindo, há mais de 30 anos, referência para as pesquisas comunicacionais em nível nacional e mundial. E mais que isto: deve-se também à peculiaridade com que a questão da alteração curricular tem sido tratada tanto por docentes quanto por discentes da instituição em disputadas e inflamadas reuniões com rica diversidade de posições e pensamentos.

Paralelamente ao desenvolvimento de uma sistemática pesquisa documental para subsidiar o trabalho com uma bibliografia específica das áreas de Educação, Cidadania e Jornalismo, em fevereiro de 2004 dei início ao trabalho de campo ${ }^{60}$.

O atual currículo da graduação em jornalismo adotado na instituição foi o primeiro objeto de análise. A partir do currículo, constatamos que as disciplinas obrigatórias que apresentam, em suas ementas, conteúdos pertinentes à cidadania (ou temas afins) concentram-se do primeiro ao quarto período. Nesta triagem constatamos que do total das 31 (trinta e uma) disciplinas obrigatórias, 11 (onze) apresentam claramente conteúdos afins com o que nos propomos a estudar.

Os resultados desta primeira fase da pesquisa nos levam a pensar na seguinte direção em relação à habilitação de jornalismo da ECA / USP: a grade curricular do curso contempla a formação cidadã do jornalista especialmente nos primeiros períodos já que, num total de oito semestres de duração do curso, encontramos, no primeiro semestre: Legislação e Deontologia do Jornalismo, Fundamentos Teóricos da História, Pensamento Filosófico e

\footnotetext{
${ }^{60}$ Vale ressaltar que consideramos o curso noturno em detrimento do diurno.
} 
Jornalismo no Rádio e na TV; no segundo: História das Doutrinas Políticas, Ética, Laboratório de Iniciação ao Jornalismo e Sociologia da Era Virtual; no terceiro: História do Jornalismo I (Geral) e Fundamentos da Economia e, por fim, no quarto: História do Jornalismo II (Brasil).

Numa segunda fase da pesquisa, acompanhamos, durante o primeiro semestre de 2004, o processo de edição de um dos veículos do curso, o J ornal do Campus, produzido por alunos do quinto semestre do curso de jornalismo noturno e partimos para entre vistas com os referidos discentes. Consideraremos como amostragem para as entrevistas, discentes os alunos do quinto semestre noturno de jornalismo por entendermos que estes, por estarem no meio do curso, polarizam bem a aplicação (ou não) de um conteúdo teórico recebido de forma mais intensa nos quatro primeiros semestres do curso nas atividades laboratoriais.

Com a idéia de vincular o aluno entrevistado à sua produção laboratorial, a amostragem - por edição61 - foi formada pelos alunos que se revezavam na secretaria de redação (geralmente um aluno), por aqueles cuja matéria era manchete (um ou dois alunos), por aqueles cuja matéria ocupava maior espaço na edição (geralmente dois alunos, nesta categoria permaneceram sempre as entrevistas) e por aqueles cuja matéria mais possibilitava discussões sobre cidadania ou temas afins (geralmente um aluno).

Os resultados da pesquisa com os discentes, considerando a produção laboratorial do Jornal do Campus nos levam ao seguinte resultado em relação à habilitação de jornalismo da ECA / USP:

1.Para os discentes, os conceitos de cidadania têm aparecido na didática do docente e na sua relação com a turma;

2. Para os discentes, os conceitos de cidadania aparecem na relação do discente com o mundo e a vivência acadêmica;

3.Para os discentes, os conceitos de cidadania aparecem num modelo democrático de produção laboratorial;

4. Para os discentes, os conceitos de cidadania aparecem na intenção de produção de uma informação que pretende ser clara, profunda e bem apurada.

$\mathrm{Na}$ terceira etapa da pesquisa, foram catalogados os temas dos projetos experimentais desenvolvidos pelos alunos da graduação em jornalismo noturno da ECA nos anos de 2002 e $2003^{62}$ para tentarmos entender se e como aparecia a questão da cidadania ou temas afins. Em 2002 houve um total de 64 (sessenta e quatro) projetos de conclusão de curso em jornalismo defendidos e depositados na Biblioteca da ECA, sendo 38 (trinta e oito) do turno diurno e 26 (vinte e seis) do noturno. Em 2003, foram 55 (cinqüenta e cinco); 25 (vinte e cinco) do curso diurno e 30 (trinta) do noturno.

\footnotetext{
${ }^{61}$ Foi combinado previamente, pela turma, que as equipes se revezariam a cada duas edições. Assim, temos a mesma equipe (incluindo secretário de redação) para as edições 281 e 282; 283 e 284 e, finalmente, 285 e 286.

${ }^{62} \mathrm{O}$ ano de 2004 não foi considerado por haver apenas um projeto depositado na Biblioteca da ECA por ocasião do início dos levantamentos referidos.
} 
Os resultados desta etapa da pesquisa, que toma como referência os 56 (cinqüenta e seis) projetos experimentais em jornalismo realizado pelos discentes do curso noturno da ECA nos anos 2002 e 2003, nos levam ao seguinte resultado:

1. Os conceitos de cidadania (ou temas afins) aparecem em 23 (vinte e três), ou seja, $41,07 \%$, de um total de 56 (cinqüenta e seis) projetos defendidos nos anos 2002 e 2003;

2. Os conceitos de cidadania, que aparecem nos 23 projetos, 12 (doze), 52,17\%, trabalham com minorias, como deficientes, pessoas com HIV e mulheres; 10 (dez), 43,47\%, apresentam questões associadas à democracia, como a ocupação de espaços físicos e democratização da comunicação, e 1 (um), 4,34\%, discute a ecologia como valor de cidadania;

3. Os conceitos de cidadania que aparecem nos projetos, TODOS apontam um problema ou uma crítica social de algo que pode ser resolvido na comunidade ao ser mais bem trabalhado por uma mídia, seja ela institucional ou alternativa.

Finalmente, agora damos início à quarta e última etapa da pesquisa. Deixamos esta fase por último por entendermos que o docente constitui um amálgama especial na pesquisa hora desenvolvida. Ao contrário do currículo, das ementas e dos conteúdos programáticos, o docente pode avançar ou não além dele, no sentido da cidadania. Ele é um elemento permanente e histórico. Em segundo lugar, por ser sua intervenção, no caso desta pesquisa, essencial para amarramos e costurarmos dados que por ventura tenham ficado obscuros em algumas das etapas anteriores.

Serão entrevistados nesta etapa final 13 (treze) docentes do Curso de Comunicação Social - habilitação em Jornalismo - da ECA que foram responsáveis pelas disciplinas no ano letivo de 2004. A amostragem levou em consideração, num primeiro momento, as disciplinas que apresentavam mais claramente conteúdos associados à cidadania (apontadas na primeira fase da pesquisa) e, num segundo, as disciplinas profissionalizantes com ênfase em jornalismo impresso, já que este tem sido o mote principal da formação técnica do jornalista ecano. Assim, nesta segunda fase desta etapa da pesquisa serão entrevistados os docentes das disciplinas de Laboratório em J ornalismo Impresso I, II, III e Revista.

O quadro a seguir esclarece melhor a questão ao apontar os docentes da amostragem desta etapa do trabalho: 


\begin{tabular}{ll}
\hline Disciplina & Docente \\
\hline Legislação e Deontologia do J ornalismo & Patrícia Patrício \\
Fundamentos Teóricos da História & Alice Mitika Koshyama \\
Jornalismo no Rádio e na TV & Luiz Fernando Santoro \\
Pensamento Filosófico & Rosana Lima Soares \\
Sociologia da Era Virtual & Ciro Marcondes Filho \\
Laboratório de Iniciação ao J ornalismo & Dennis de Oliveira \\
História das Doutrinas Políticas & Cláudia Lago \\
Ética & Mayra Rodrigues Gomes \\
Fundamentos da Economia & Eun Yung Park \\
História do Jornalismo I (Geral) & Alice Mitika Koshyama \\
História do J ornalismo II (Brasil) & Alice Mitika Koshyama \\
Laboratório em J ornalismo Impresso I & J osé Luís Proença \\
Laboratório em J ornalismo Impresso II & J osé Coelho Sobrinho \\
Laboratório em J ornalismo I mpresso III & Nancy N. Ramadan \\
Laboratório em J ornalismo I mpresso - Revista & Cláudio Tognolli \\
\hline
\end{tabular}

Neste sentido, solicito a sua colaboração nesta fase final da pesquisa, preenchendo o questionário anexo que entrego e recolherei pessoalmente em dia e hora marcados.

Sem mais, agradeço a contribuição.

Enio Moraes Júnior

(11) $3865-2185 /$ (11) $9148-1514$

emoraesj@uol.com.br

\footnotetext{
${ }^{63}$ Aqui não consideramos a disciplina Projetos Experimentais em J ornalismo por não haver uma configuração de aula convencional. A disciplina funciona com professores-orientadores escolhidos pelos alunos de acordo com o tema do trabalho.
} 


\section{Anexo 11}

Questionário aplicado aos docentes do curso de Jornalismo da ECA 


\section{Universidade de São Paulo}

Departamento de J ornalismo e Editoração

Núcleo de J ornalismo Comparado

Programa de Pós-Graduação em Ciências da Comunicação - Jornalismo

\section{Questionário de Pesquisa}

Parte dos estudos para a dissertação A formação cidadã do jornalista no Brasil

01. Atividades docentes

1A. Há quanto tempo leciona no ensino superior?

a. ( ) Há menos de um ano

b. ( ) Entre um e cinco anos

c. ( ) Entre cinco e dez anos

d. ( ) Entre dez e vinte anos

e. ( ) Há mais de vinte anos

1B. Há quanto tempo leciona na ECA?
a. ( ) Há menos de um ano
b. ( ) Entre um e cinco anos
c. ( ) Entre cinco e dez anos
d. ( ) Entre dez e vinte anos
e. ( ) Há mais de vinte anos

1C. Além da ECA, leciona em outra graduação?
a. ( ) sim
b. ( ) não. Neste caso, pule para a questão 1E.

1D. As disciplinas lecionadas nesta outra graduação têm alguma relação com a cidadania ou temas afins?
a. ( ) sim
b. ( ) não

1E. Leciona na pós- graduação da ECA?
a. ( ) sim
b. ( ) não. Neste caso, pule para a questão $1 \mathrm{G}$.

1F. As disciplinas lecionadas na pós-graduação têm alguma relação com a cidadania ou temas afins?
a. ( ) sim
b. ( ) não

1G. Leciona em outra pós-graduação?
a. ( ) sim
b. ( ) não. Neste caso, pule para o item 02 .

1H. As disciplinas lecionadas nesta outra pós-graduação têm alguma relação com a cidadania ou temas afins?
a. ( ) sim
b. ( ) não

02. Atividades no mercado profissional

2A. Tem experiência no mercado de trabalho na área de comunicação?
a. ( ) sim
b. ( ) não. Neste caso, pule para o item 03.

2B. Durante quanto tempo?
a. ( ) Menos de um ano
b. ( ) Entre um e cinco anos
c. ( ) Entre cinco e dez anos
d. ( ) Entre dez e vinte anos
e. ( ) Há mais de vinte anos 
2C. Estas experiências foram / são relevantes para agregar conteúdos relativos à cidadania ou temas afins no ensino do jornalismo?
a. ( ) sim
b. ( ) não

03. Interfaces com a cidadania na formação do docente

3A. Durante a(s) sua(s) graduação(ções) você participou ou desenvolveu projetos em que a cidadania (ou temas afins) tinha um valor relevante?
a. ( ) sim
b. ( ) não

3B. Durante a sua última pós-graduação você participou ou desenvolveu projetos em que a cidadania (ou temas afins) tinha um valor relevante?
a. ( ) sim
b. ( ) não

3C. Você participa de algum projeto de pesquisa ou extensão universitária?
a. ( ) sim
b. ( ) não. Neste caso, pule para o item 04.

3D. Em algum desses projetos a cidadania (ou temas afins) tem / tinha um valor relevante?
a. ( ) sim
b. ( ) não

04. Interfaces com a cidadania na atividade docente na graduação da ECA

4A. Nuca escala de 0 a 10, qual o valor que você atribui à cidadania (ou temas afins) como parte do conteúdo da disciplina da ECA que o (a) coloca como amostragem desta pesquisa?
0.( ) 1.( ) 2.( ) 3.( ) 4.(

11. ( ) Não saberia avaliar

4B. Por quê?

4C. Como este conteúdo é trabalhado em sala de aula? (Pode ser assinalada mais de uma alternativa)
a. ( ) Este conteúdo não é trabalhado em sala de aula.
b. ( ) Do ponto de vista teórico
c. ( ) Do ponto de vista teórico e prático em atividades propostas
d. ( ) Na relação que procura estabelecer com o discente
e. ( ) Na relação que permite / estimula que o discente estabeleça com a disciplina
f. ( ) Na relação que permite / estimula que o discente estabeleça a sua formação
g. ( ) Na relação que permite / estimula que o discente estabeleça a sua produção
h. ( ) Outros. Especifique

4D. Numa escala de 0 a 10, qual o valor que você atribui à cidadania (ou temas afins) como parte do conteúdo do conjunto das disciplinas que leciona na graduação da ECA?

0.( ) 1.( ) $2 .($ ) 3.( ) $4 .($ ) $5 .($ ) $6 .($ ) $7 .($ ) $8 .($ )

11. ( ) Não saberia avaliar

4E. Por quê? 
4F. Você orientou, nos últimos dois anos (2003 e 2004), projetos experimentais realizados por alunos de jornalismo noturno da ECA que abordasse, direta ou indiretamente, cidadania ou temas correlatos, como democracia, direitos humanos, responsabilidade social do jornalismo ou ética profissional?
a. ( ) sim
b. ( ) não. Neste caso, pule para a questão $4 \mathrm{H}$.

4G. Quantos projetos você orientou jornalismo noturno da ECA com esta temática nos últimos dois anos (2003 e 2004)?
a. ( ) Apenas um
b. ( ) Entre um e cinco
c. ( ) Entre cinco e dez
d. ( ) Entre dez e vinte
e. ( ) Há mais de vinte

$4 \mathrm{H}$. Numa escala de 0 a 10, em que escala você percebe a cidadania (ou temas afins) nos trabalhos de conclusão de curso realizados pelos alunos concludentes de jornalismo da ECA?

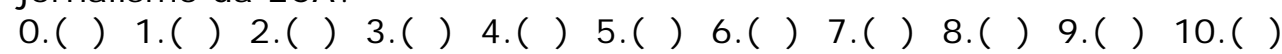

11. ( ) Não saberia avaliar

41. Por quê?

4). Numa escala de 0 a 10, qual o valor que você atribui à cidadania (ou temas afins) no atual currículo de formação do jornalista ecano?

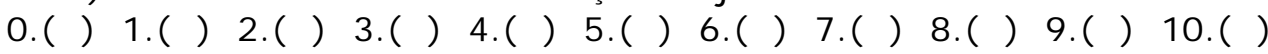

11. ( ) Não saberia avaliar

4K. Por quê?

05. Identificação do docente

Nome:

5A. Qual (is) a(s) área (s) em que se graduou?

5B. Titulação:
a. ( ) Graduado
b. ( ) Especialista
c. ( ) Mestre
d. ( ) Doutor
e. ( ) Pós-doutor

\author{
Muito obrigado. \\ Enio Moraes Júnior
}

São Paulo, 10 semestre de 2005. 


\section{JORNAL DO CAMPUS Escola de Comunicações e Artes - Universidade de São Paulo - $1^{\circ}$ a 21 de abril de 2004 - Número 281, Ano 22}

\section{Cursos na ZL causam polêmica}

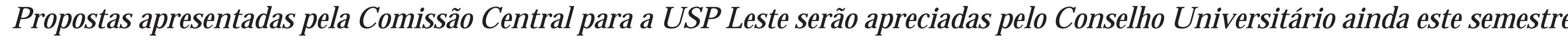

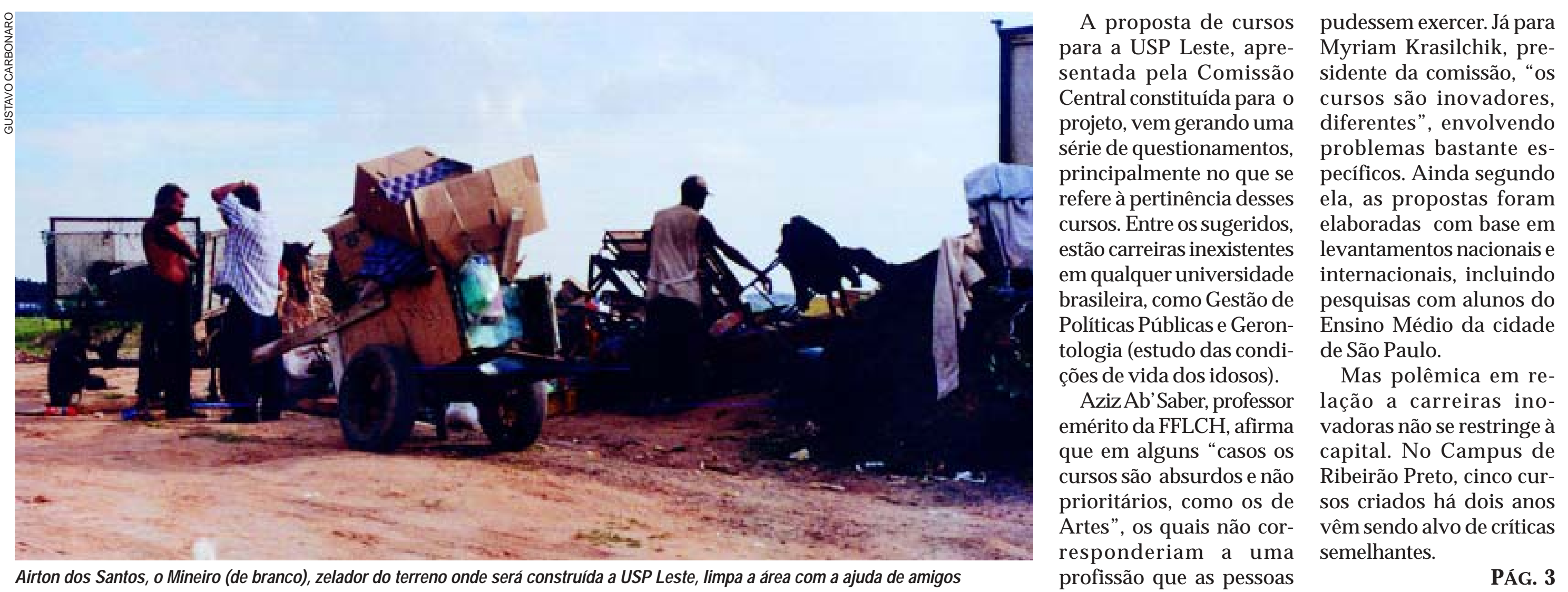

Fonte de financiamento para auxílio estudantil pode acabar

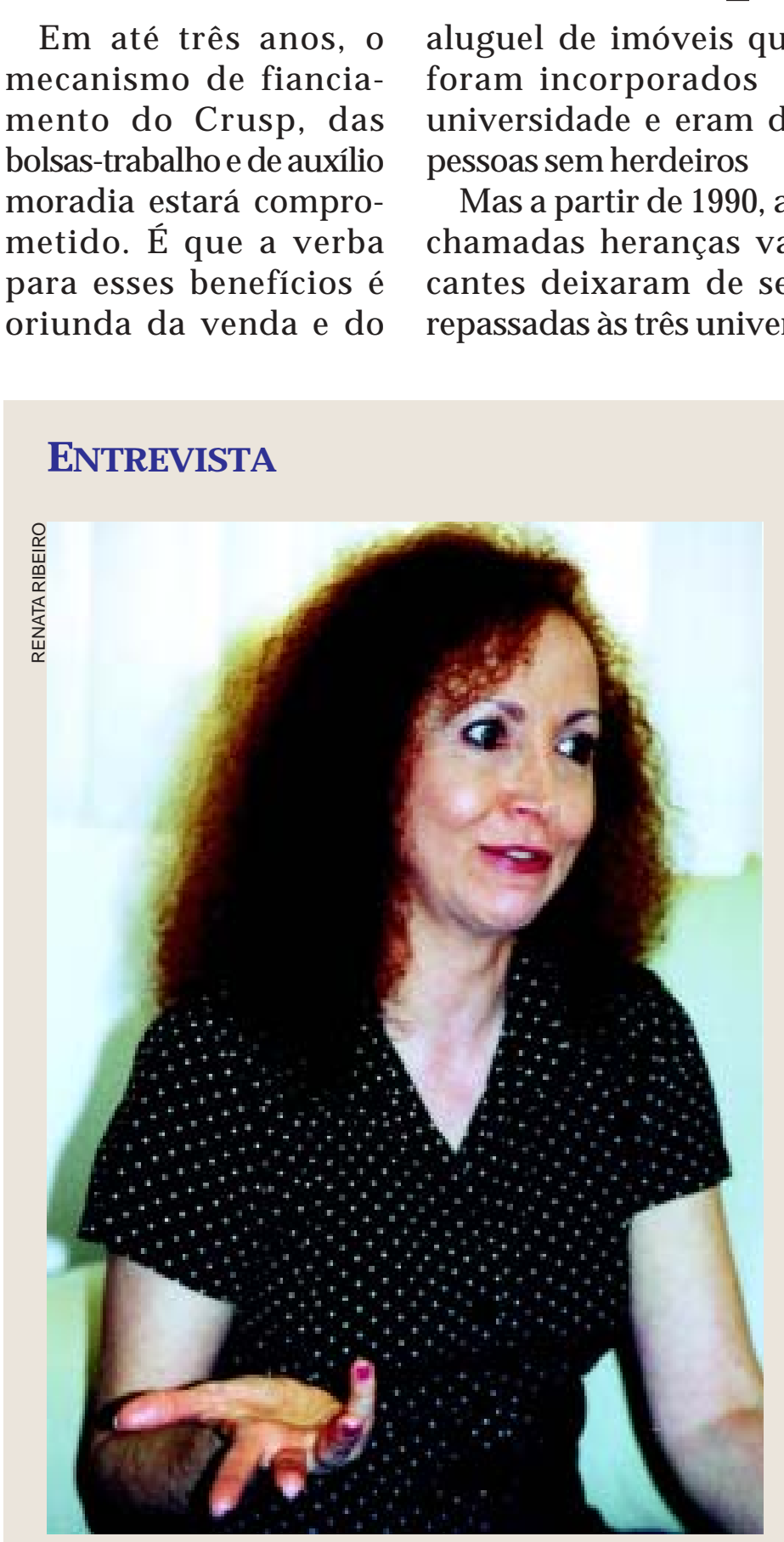

Aquino comenta a ditadura e suas conseqüências para o país

As veias abertas pela Ditadura Militar

Há exatos 40 anos, ocorria o golpe militar que instalou o regime ditatorial que durou de 1964 a 1985. Em entrevista ao Jornal do Campus, Maria Apar ecida de Aquino, professora do Departamento de História da USP, fala sobre esse período de nossa história. "Toda a riqueza do Brasil é drenada para o pagemento de juros. Isso é uma herança do regime militar", afirma.

PÁG. 7

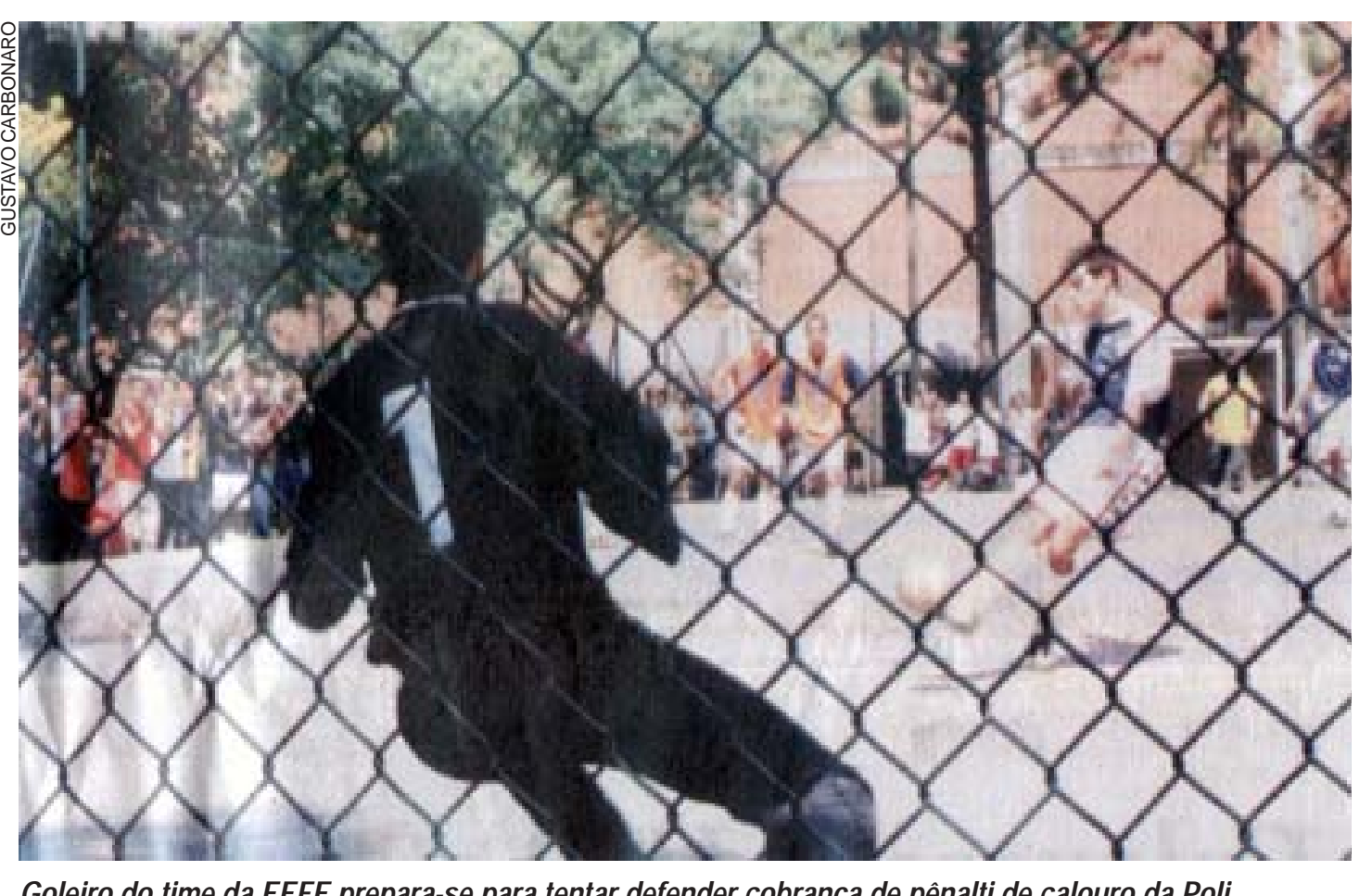

BichUSP expõe diferenças entre atléticas e integra calouros

Jornal do Campus traz

coluna Identidade, desti-

nada a retratar persona-

ajudane, de sua forma,

dia da maior universidade

o país e sua história.

Belchor Fontes, profes-

sor da Faculdade de Medi-

cina, inaugura o espaço. "A

USP é o sustentáculo de

(ninha vida em to

Diretoria do

Campus Bauru

proíbe uso de

minissaias

Desde o início do ano

letivo, a diretoria do Cam-

pus Bauru vem recomen-

dando aos alunos que não

usem trajes como ca-

saias e bermudas.

Porém, segundo relato dos alunos, isso virou uma imposição, já que os estudantes que não estiverem vestidos adequadamente são proíbidos de entrar nas salas de aula.

PÁG. 5

O clássico BichUSP, tor- marcada por diferenças outro o que se via eram eio que integra os alunos abismais entre as atléticas equipes desfalcadas, com rém ingressados na participantes. atletas que disputavam De 8 a 11 de abril ser de março, no campeãs(EEFE, Poli, FEA) realizada a terceira edição Cepeusp. Como em outros e seu poderoso arsenal de do Torneio da USP. anos, a competição foi bixos selecionados. De $\quad$ PÁG. 6 Painel do Campus

Sebastião Salgado retoma suas origens em exposição

Aberta até dia 20 de abril no Museu de Arte Contemporânea (MAC), In Principio traz 25 fotos que contam o caminho otógrafo cresceu, até os portos.

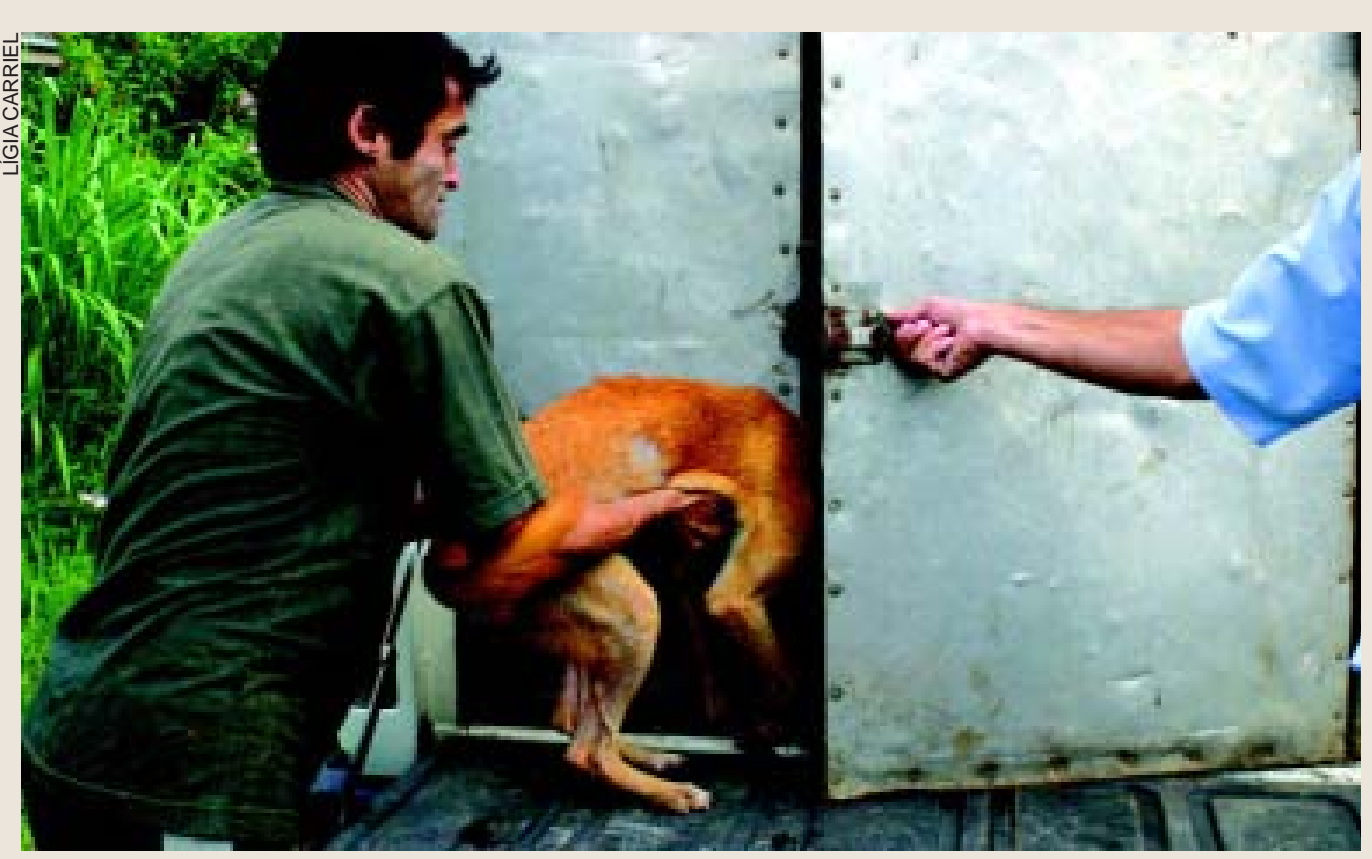
SERÁ O FIM? Após muita indefinição, no dia 31 passado a Prefeitura do Campus (PCO)
começou a desativar o canil situado próximo à ECA. Os animais irão para um local na própria PCO.
DeBATE

Calouros comentam suas expectativas em relação à USP

Ao sonhos. No entanto, muitos acabam se esfalecendo perante os 


\section{JORNAL DO CAMPUS}

\section{Protestos e confusão marcam reunião aberta do Conselho sobre fundações}

Ofendido por um manifestante, reitor encerra a sessão antes do debate; estudantes ocupam auditório e saem em passeata pelo campus
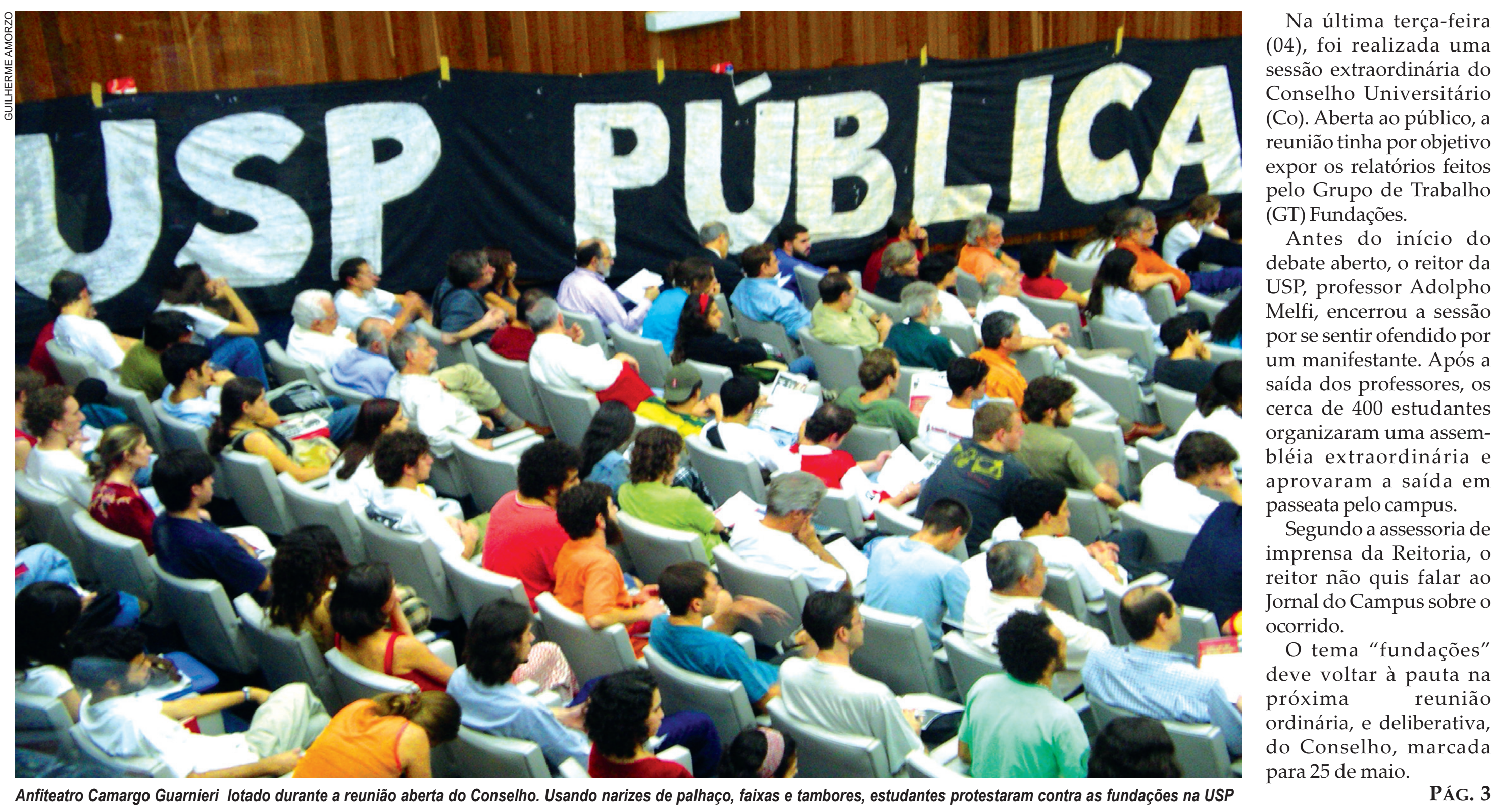

Painel do Campus

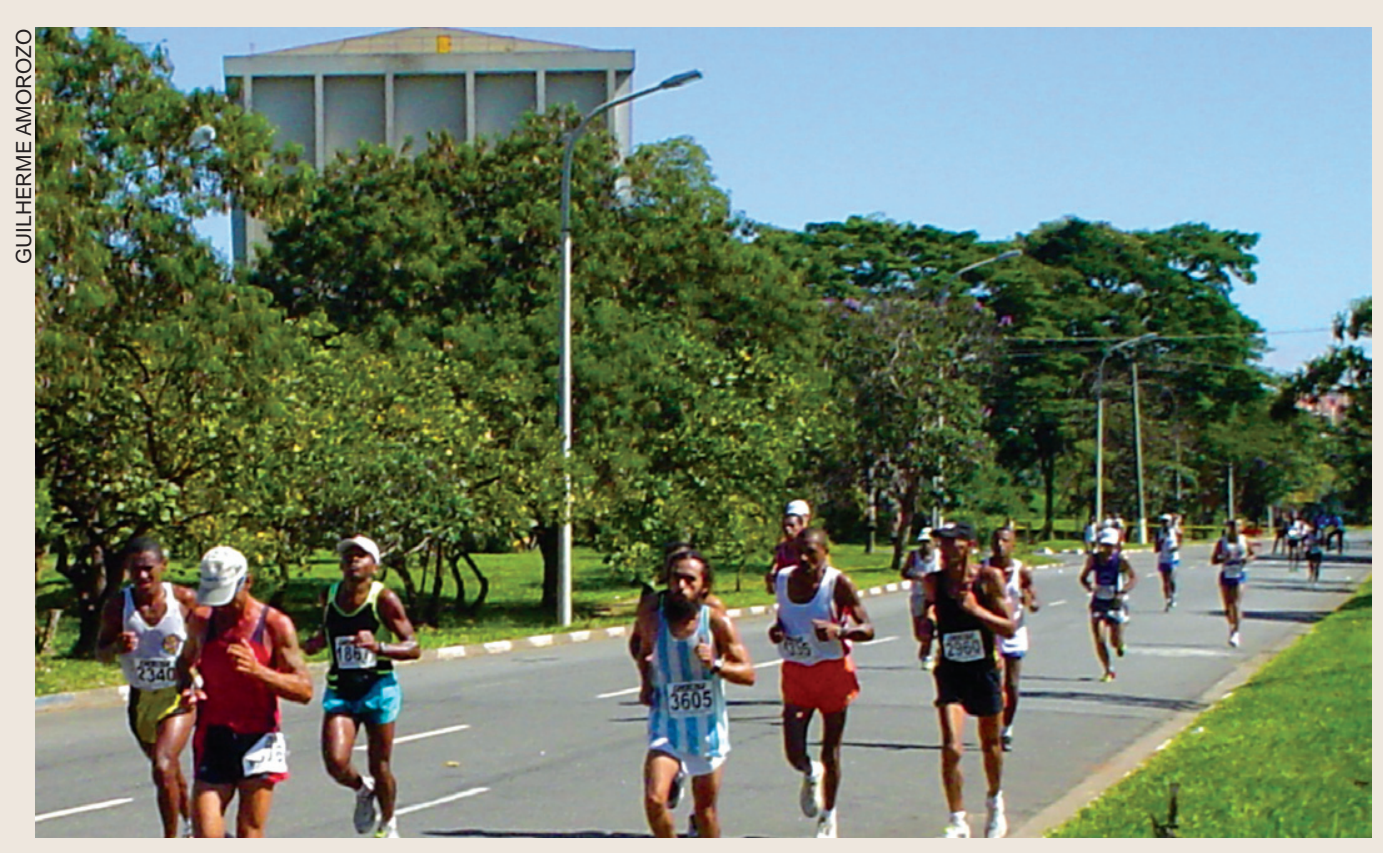

MARATONA Dia 2 de maio, domingo passado, a Maratona Internacional de São Paulo passou por dentro da USP. A maior prova brasileira da categoria, com mais de 6 mil participantes,
completou 10 anos. A queniana Margareth Carie e o brasileiro Frankc Caldeira foram os vencedores.
Atraso da reitoria pode deixar 700 alunos sem cursos populares $\begin{aligned} & \text { A Reitoria excedeu em } \text { Campus, funcionários da } \\ & 120 \text { dias oprazo dado pelo } \text { consultoria indicaram a } 700 \text { alunos } \\ & \text { podem ser prejudicados }\end{aligned}$ Ministério Público Esta- assessoria de imprensa da com a saída dos cursinhos. dual para resolver a USP para falar do assunto. A Reitoria, por meio da populares pagos na USP. aos responsáveis pelos afirma não poder assumir A extrapolação foi cursinhos exigindo o fim os cursos. Wallace Paiva decoren promotor do caso, diz que conivulo Juridica da taxasearegularizaçao dos dentro da USP "não há um parecer sole coso. de 30 dias carocontrário de Procurados pelo Jornal do terão que sair do campus. PÁG. 5

Basquete do HC disputa vaga nas Paraolimpíadas de Atenas
Seguranças da FFLCH são afastados

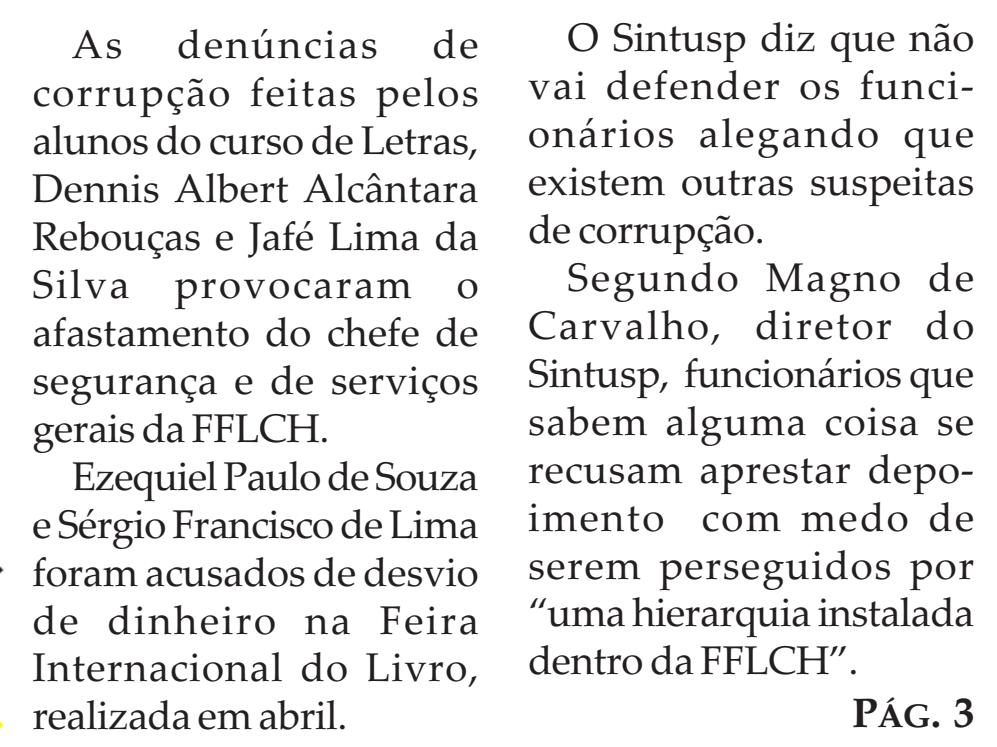

UNIVERSIDADE

Presença de crianças dentro do campus causa desconforto

A comunidade uspiana engloba mais do que alunos,
professores e funcionários. Crianças e adolescentes utilizam e divergências. Como melhorar a situação?
"O problema é que o Brasil está no quarto mundo"

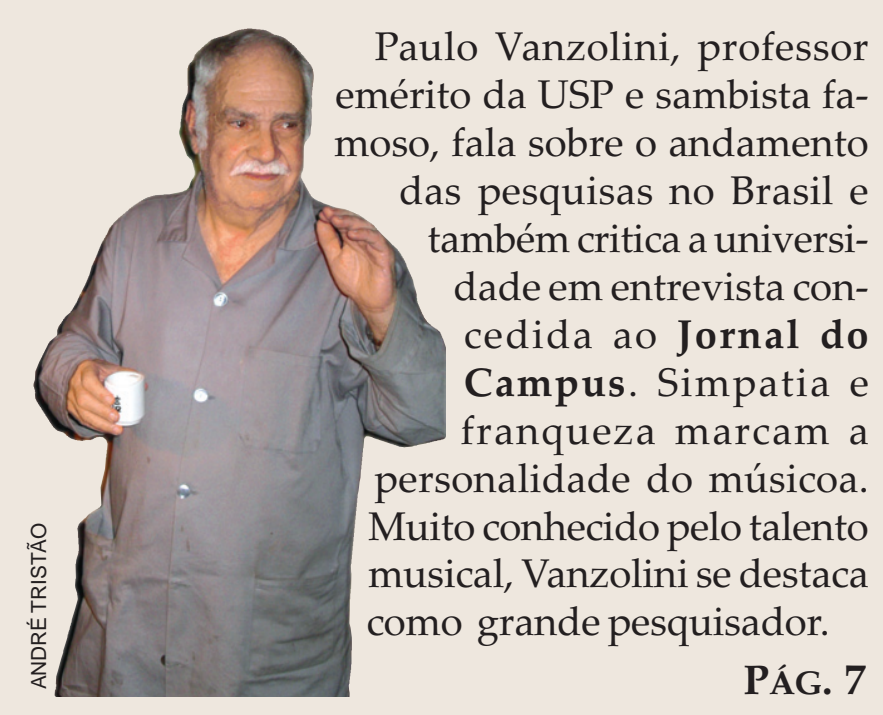

Cultura

Centro cultural oferece cinco novas exposições ao público

Até o dia 13 de junho, cinco artistas diferentes expõem no
Centro Universitário Maria Antônia. As mostras incluem Centro Universitário Maria Antônia. As mostras incluem
gravuras, montagens, performances inusitadas e peças feitas na hora, que podem ser levadas para casa. PÁG. 8

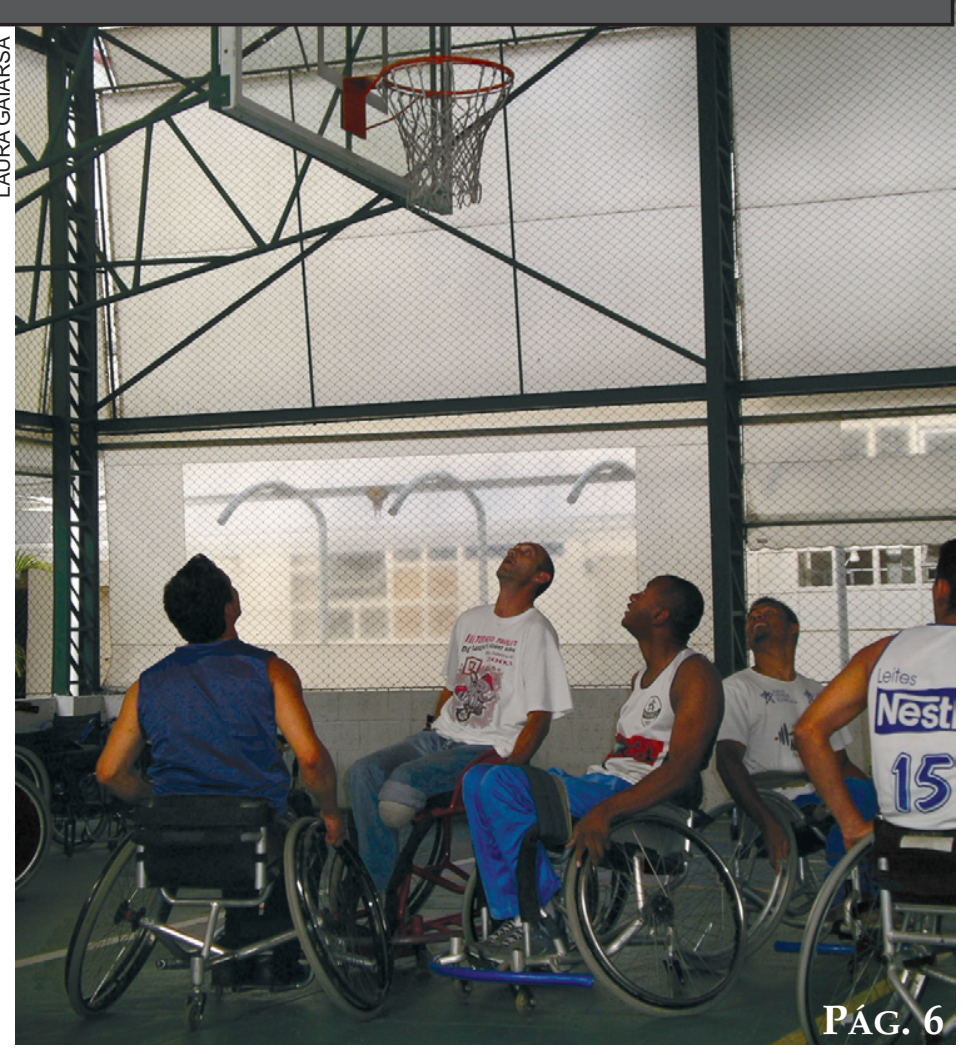

DEBATE

A dificuldade de equilibrar teoria e prática nos cursos

Reformas curriculares causam discussão sobre a influência conciliar a parte prática com a teórica. Será que a única função da faculdade é preparar o aluno para o trabalho? PÁG. 2 


\section{JORNAL DO CAMPUS}

Escola de Comunicações e Artes - Universidade de São Paulo - 4 a 17 de junho de 2004 - Número 285, Ano 22

\section{USP pára a espera de reajuste salarial}
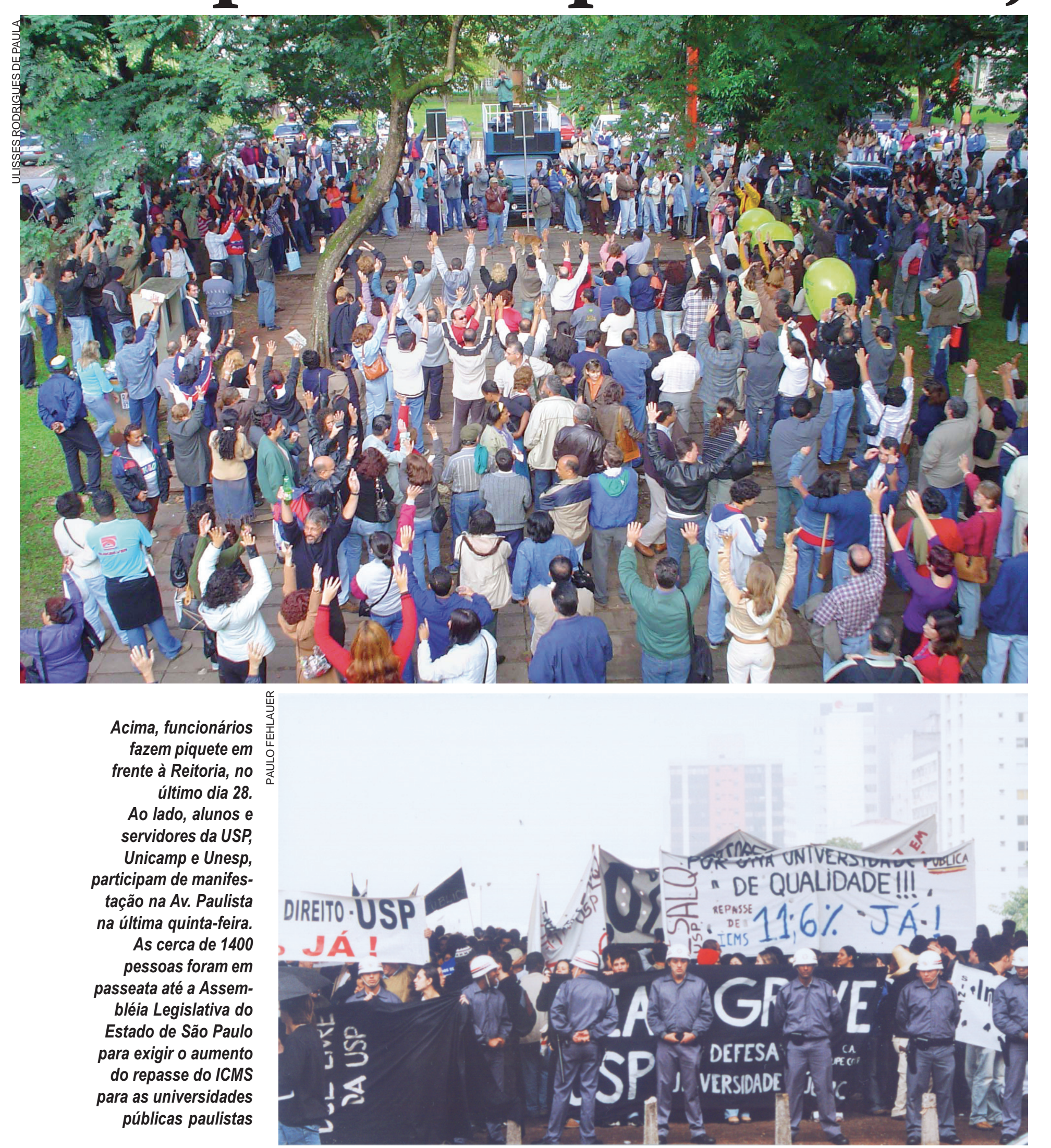

Carrinhos de rolimã descem Rua do Matão em GP da Poli

O36 GP Poli NSK, a tradicional corrida de carrinhos de rolimã, aconteceu dia 29 de maio. Os competidores desceram a Rua do depois de algumas curvas e lombadas, muitos ficaram pelo caminho. Mesmo são foi garantida. PÁG. 6

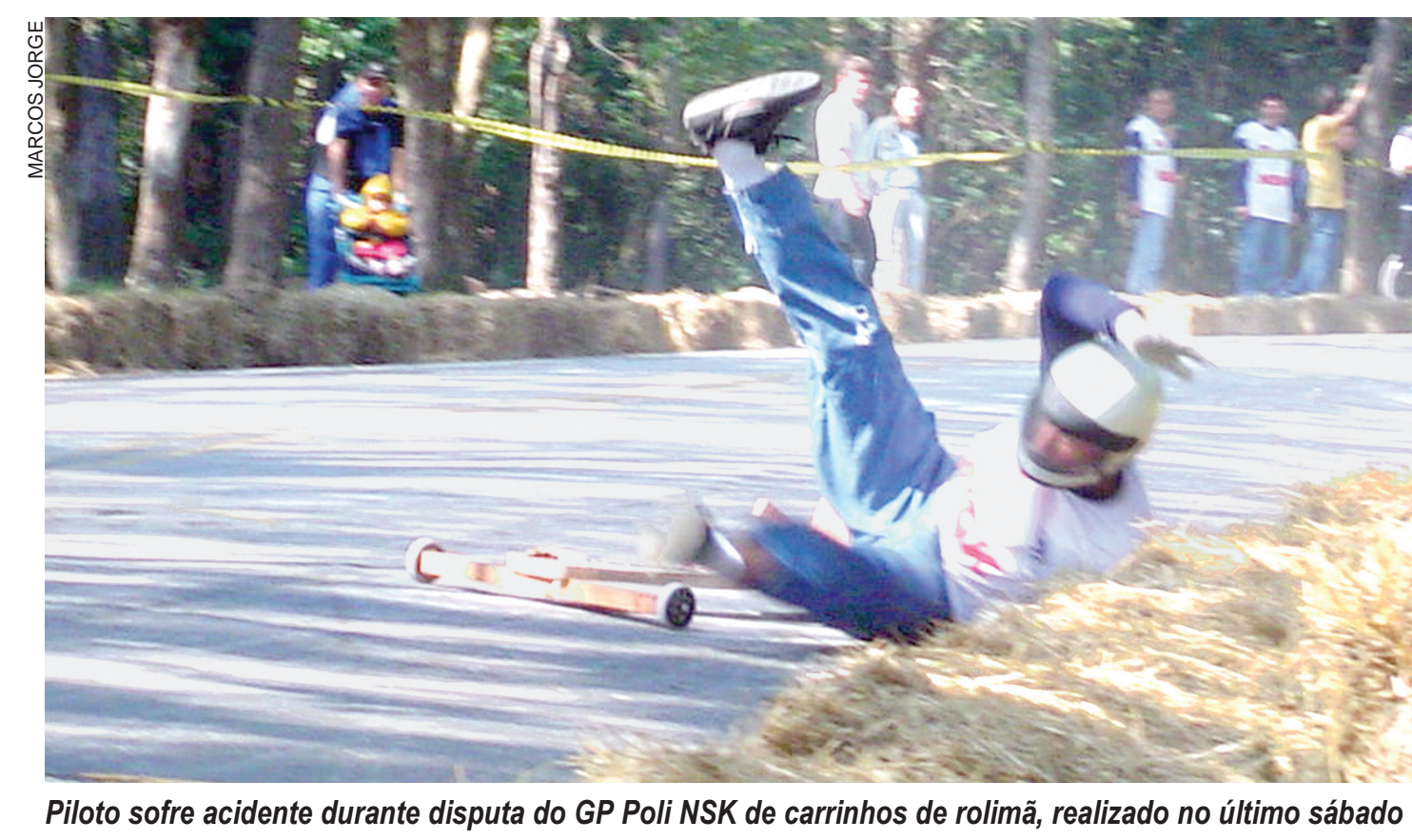

Painel do Campus

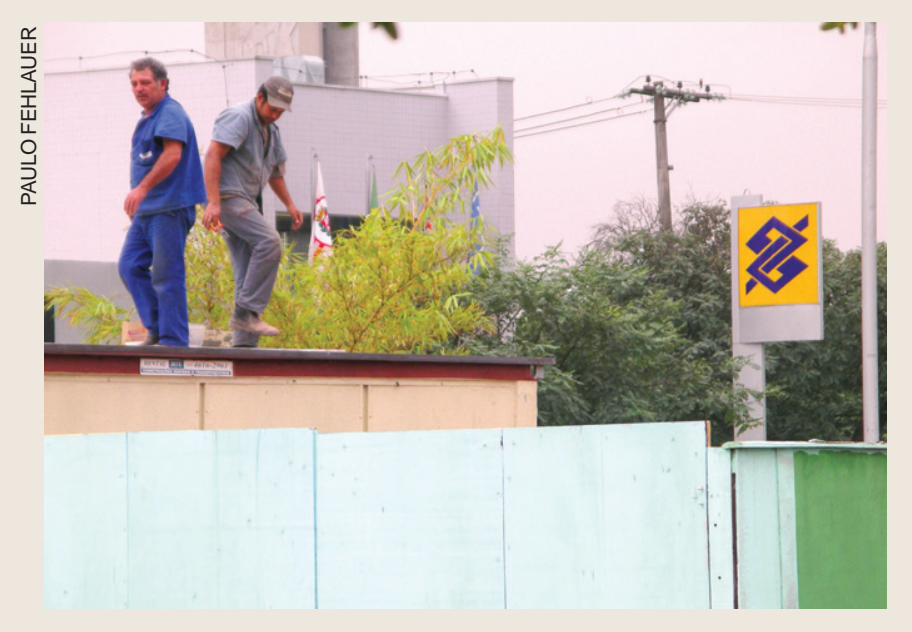

EM OBRAS Os tapumes no estacionamento dos bancos, na Av. Luciano Guallberto, escondem a construção de ou-
tra agência no espaço - futura instalação do Banco Real

Debate

Opinióes sobre greve dividem alunos da universidade

Á medida que a greve cresce, aumentam as discussões sobre
sua legitimidade, organização e desenvolvimento. Estudantes paraliscã e articulam opiniñ se sobre tema.
Alunos propõem melhorias para sistema de circulares

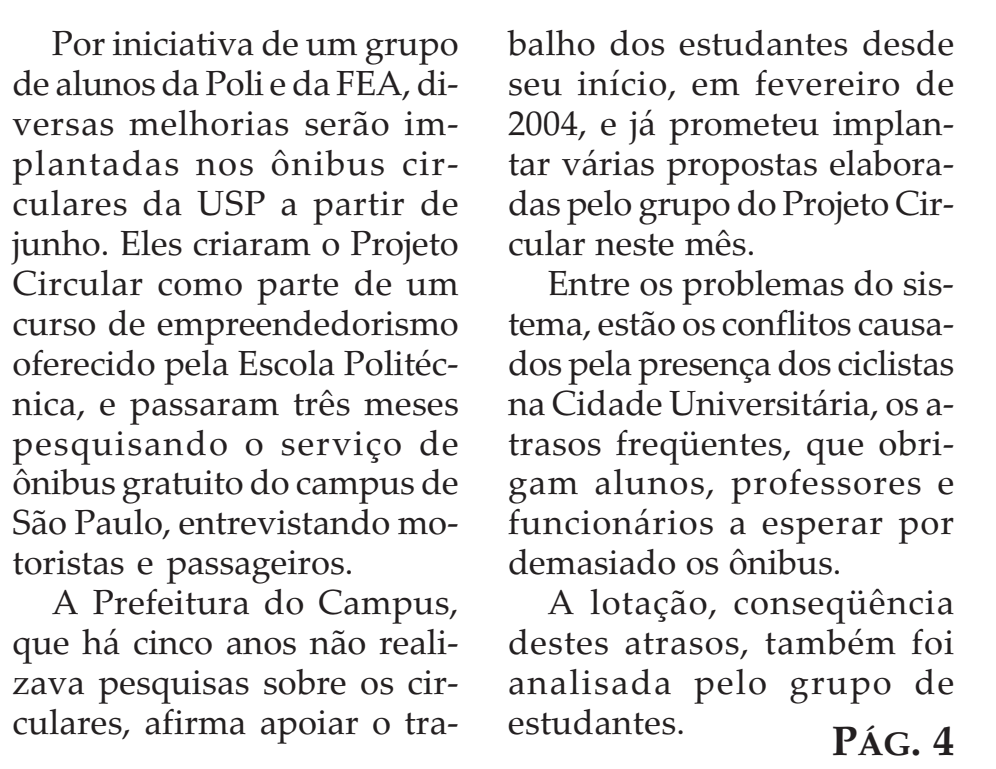

UNIVERSIDADE

Manifestantes invadem aulas de cursos pagos em protesto

Cerca de 50 alunos interromperam aulas e ocuparam classes
utilizadas pelos cursos pagos de MBA da FEA e da Poli, nos utilizadas pelos cursos pagos de MBA da FEA e da Poli, nos
últimos dias 26 e 27 . Comandados pelo DCE, intencionavam ampliar a discussão sobre as fundações na USP PÁG.
- Funcionários e professores exigem aumento de $16 \%$ e maior repasse do ICMS

- Cruesp mantém 0\% e marca nova reunião para a próxima segunda-feira

- Estudantes se reúnem em assembléia e decidem apoiar o movimento grevista

Funcionários e professo- Universidades Estaduais res das três universidades Paulistas (Cruesp) . públicas estaduais de São A última assembléia da Paulo estão em greve des- Associação dos Docentes de o dia 27 de maio. Ape- da USP (Adusp), dia 31, . essa é, segundo o Sindica- professores, número supe USP (Sirabahnadores da rior aos 50 docentes preUSP (Sintusp), a greve de sentes na primeira reunião doscine mais rápido que deliberou pela greve. dos últimos dez anos. A Eles defendem uma auprincipal explicaçao estaria mentodorepasse doICMS no inedito $0 \%$ de reajuste, e das verbas para a educaferecido três vezes pelo ção em todos os níveis.

Cursinho da Poli é acusado de esquecer inclusão social

A gestão do Grêmio da clusão socil", diz tayd P a atual política de expan- mio e membro do Conseão do Cursinho da Poli, lho Curador do cursinho nem com o aumento da Ela reclama de falta de sua taxa de manutenção. transparência nas contas OGrêmio acusa o cursi- envolvendo o cursinho. nho de adotar políticas que Segundo o diretor exenão levam em conta a idéia cutivo, Fábio Sato, todas as original por tras de sua cri- contas podem ser es şo a súve com cin $\begin{array}{ll}\text { so acessivel a comunida- } & \text { a expansão e o aumento da } \\ \text { des carentes. } & \text { mensalidade não fizeram }\end{array}$ Em 2003, a mensalidade com que o cursinho deido curso extensivo matu- xasse de oferecer bolsas tino de bio/exatas era $\mathrm{R} \$$ para a comunidade caren167. Este ano, aumentou te, após análise sociopara R\$265. Com 17 mil econômica. Sato ainda cita vagas, o cursinho tem $6 \mathrm{mil}$ parcerias com as prefeitualunos frequentando as ras de São Paulo, que en“O cursinho está fugin- caminha jovense paga pa"O cursinho está fugin- te da bolsa integral. do da sua proposta de in- PÁG. 5

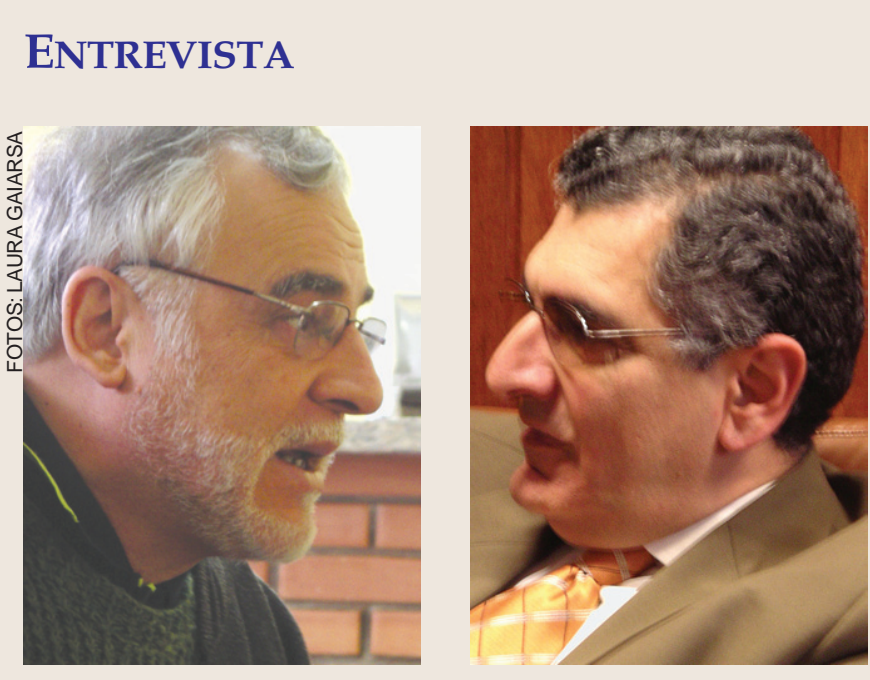

Os professores Osvaldo Coggiola (esq.) V Vahan Agopyan (dir.)

Professores expõem suas posições frente à greve

$$
\begin{aligned}
& \text { Osvaldo Coggiola, da História, e Vahan } \\
& \text { Agopyan, da Poli, falam sobre o movimento de } \\
& \text { greve e a influência deste sobre o cotidiano e o fu- } \\
& \text { turo da universidade. Apesar das diferenças de opi- } \\
& \text { nião, ambos concordam que é preciso lutar con- } \\
& \text { tra o sucateamento do ensino público superior. } \\
& \text { PáG. } 7
\end{aligned}
$$

\section{Cultura}

Palestras mantêm estudantes ocupados durante paralisação O II ciclo de palestras Cultura de Greve, organizado pelo Departamento de Artes Plásticas da ECA, estimula a discussão participação de alunos e professores da FAU. $\quad$ PÁG. 8 


\section{JORNAL DO CAMPUS}

Escola de Comunicações e Artes - Universidade de São Paulo - 21 de maio a 3 de junho de 2004 - Número 284, Ano 22

\section{parAlisaCgão}

CONFIRA ESPECIAL COM A COBERTURA COMPLETA DA MANIFESTAÇÃO DE 20 DE MAIO

USP abre 1270 vagas em novos cursos de graduação

A reunião do Conselho Universitário (Co), dia 18 de maio, aprovou a criação de 16 novos cursos, com início previsto para 2005. Essa deliberação abrirá 1270 vagas por ano. Dos 16 cursos, 10 serão no campus da Zona Leste, que ainda está em consButantã receberão os outros seis.

Também foram aprovados dois novos cursos programados para começar em 2006. Ambos são da USP Leste.

O Co foi a última etapa para que as novas propostas possam entrar em funcionamento. A aprovação possibilita que elas sejam inclusas já no próximo vestibular.

PÁG. 5

Ex-diretor da Poli é acusado de contratações irregulares

$$
\begin{array}{cc}
\begin{array}{c}
\text { Antônio Carlos Massola, } \\
\text { ex-diretor da Escola Poli- }
\end{array} & \text { dos dois possuía registro, } \\
\text { técnica, está sendo acusa- } & \text { lho Region lei, no Conse- } \\
\text { do pelo Ministério Público } & \text { (CRQ). } \\
\text { de irresponsabilidade ad- } & \text { O autor da denúncia, } \\
\text { ministrativa. } & \text { Reinaldo Vaz, foi terceiro } \\
\text { Em 2000, ele autorizou } & \text { colocado no concurso que } \\
\text { a contratação de Antonio } & \text { aprovou Monteiro e Audri. } \\
\text { Carlos Monteiro e Audri } & \text { Se Massola for condena- } \\
\text { Lanza como técnicos de } & \text { do, terá que pagar mais de } \\
\text { laboratorio no Departa- } & \text { R \$52 mil de indenização } \\
\text { mento de Engenharia Quí- } & \text { para a Universidade. } \\
\text { mica. Na época, nenhum } & \text { PÁG. } 5
\end{array}
$$

Painel do Campus

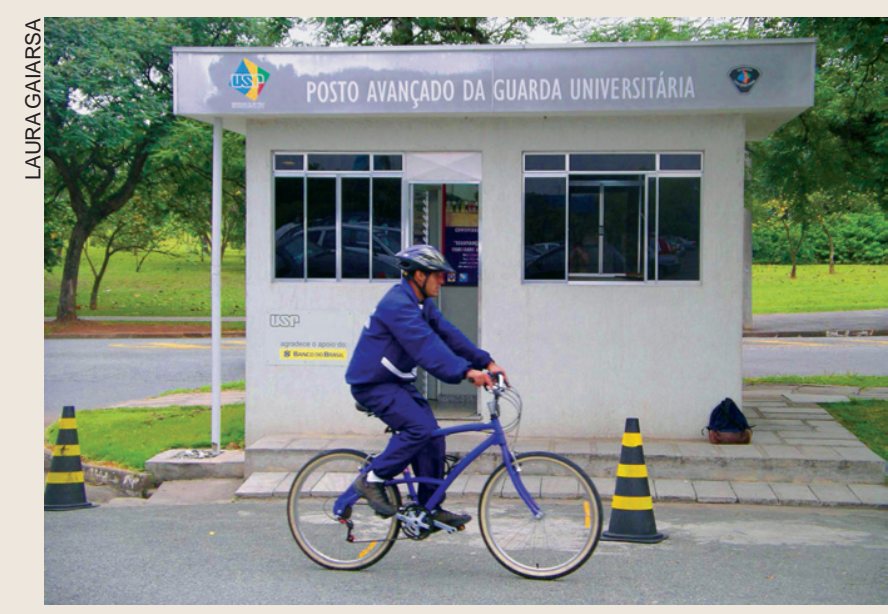

G-BIKE A Guarda Universitária tem uma equipe de dez pessoas que percorrem o campus da USP. O G-Bike, apesar de

Judoca é um dos melhores do Brasil

Luiz Tambuccie é professor de judô no Cepeusp há mais de 20 anos, e está entre os dez brasileiros que conseguiram colecionar sua faixa preta. Cada um indica o nível do atleta eo grau máximo é o décimo. Com 82 anos, o mestre

-judoca Tambucci esbanja saúde e simpatia ensinando as novas gerações, PĂG.

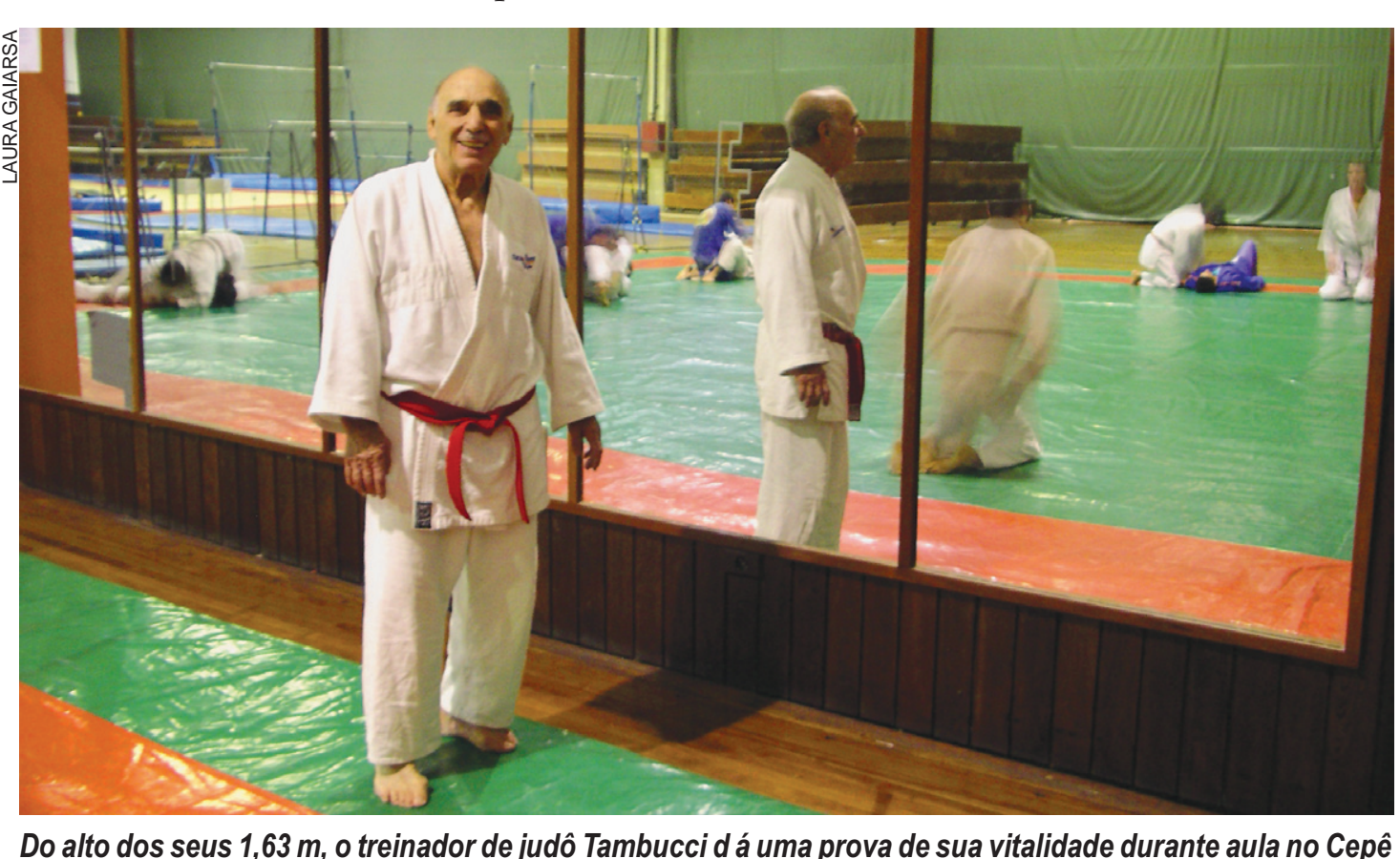

Claro!

Suplemento traz a realidade de ser mãe no Brasil

Neste final do mês das mães, o Claro! foge das maquiagen
publicitárias do segundo domingo de maio e revela o cotidiano publicitárias do segundo domingo de maio e revela o cotidian
sem perfumaria das mães brasileiras, com todas as suas dificuldades e realizações.
Cultura

MAC expõe mais de 30 obras do artista plástico Júlio Plaza

\section{CA da SanFran usa espaço público de forma indevida}

Centro Acadêmico XI de Agosto ganha dinheiro às custas de terreno doado pelo Governo

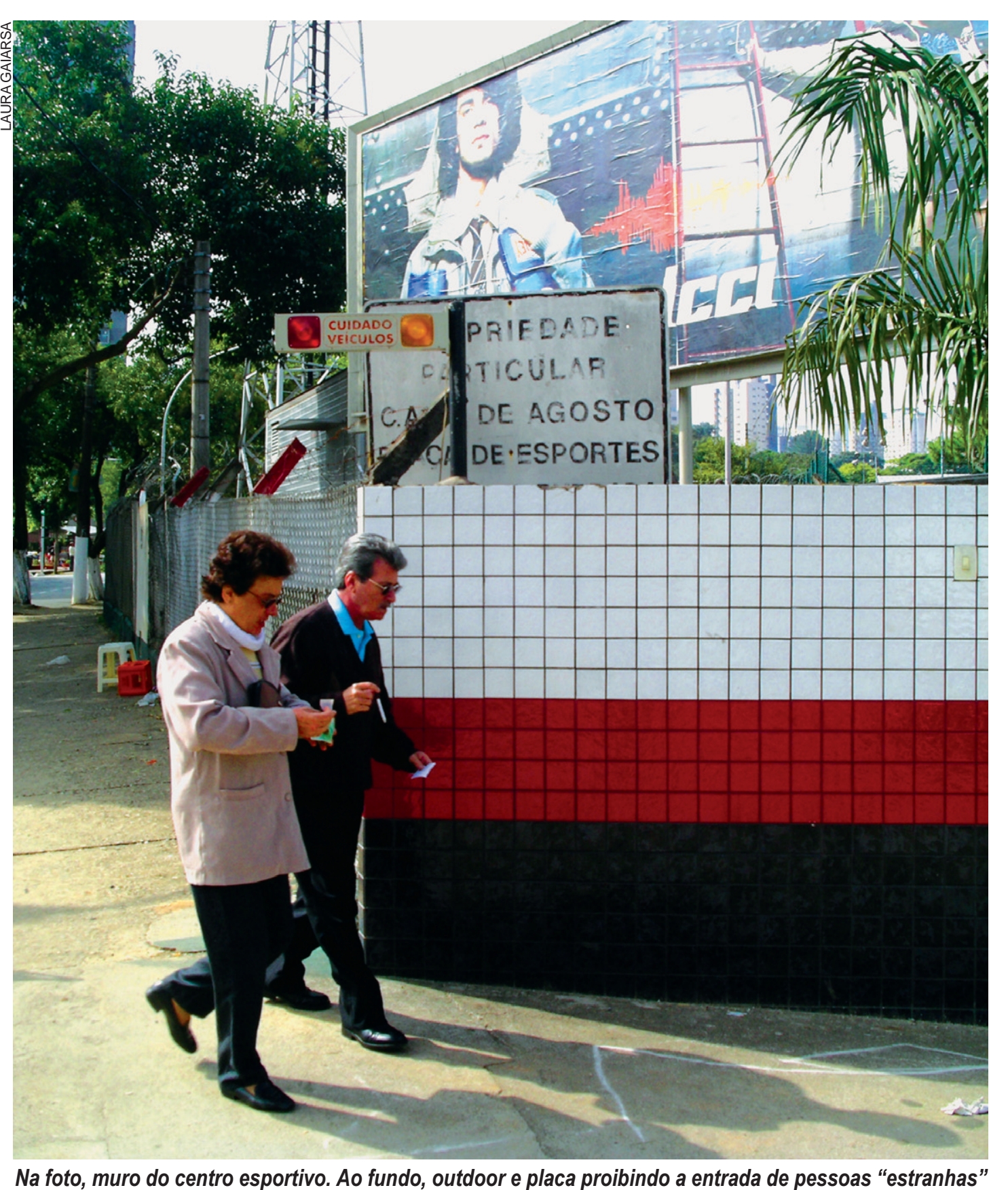

O terreno foi doado por Janio Quadros em 1955, ça de esportes aberta à comunidade. O Centro Acadêmico da Faculdade de Direito recebe em média R\$50 mil mensais pelo aluguel das quadras e do

Em 1992, o prefeito Paulo Maluf desapropriou uma parte da area para rede Maio e pagou uma indenização de R\$500 mil. Além disso, o CA XI de agosto também é processado pela falta de pagamento do IPTU, negligencia da bem na Prefeitura. A diretoria do $\mathrm{CA}$ rebate as acusaçoes afirmando que o dinheiro é revertido para outros projetos como o Departamento Jurídico, que presta atendimento a pessoas carentes. O jornalista Gilberto Dimenstein e o Secretário Municipal do Meio Ambiente Adriano Diogo levantaram a polêmica, em matéria da rádio $\mathrm{CBN}$

PÁG. 3

Fundação de alunos arrecada fundos para obra da Medicina As obras de restauro do Já foram arrecadados 16 prédio da Faculdade de milhões de reais. Medicina (FM) custarão 35 Formada em 1996, a milhões de reais. $\quad$ FFM contribui para a faculA Fundação Faculdade dade contratando funcioe Medicina (FFM) è res- nários, comprando equionsável por angariar do- pamentos e ampliando o ações e reverter o dinheiro atendimento à população.
para a reforma. "Só não podemos deixar de negociar [Alca e UE]"

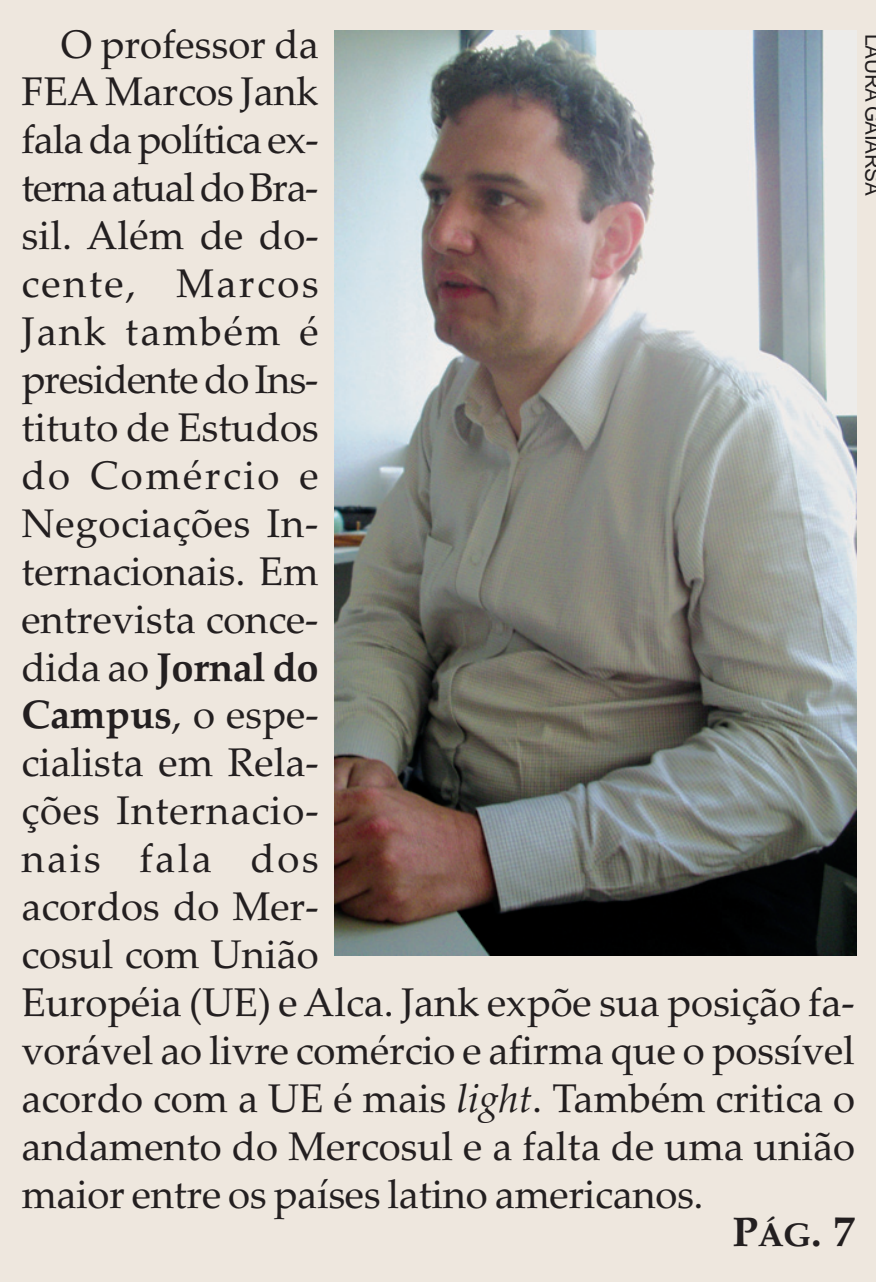

Debate

Como universitários encaram a presença de crianças na USP? A coletanea do professor da ECA falecido em 2003 , que abran-
ge principalmente o trabalho realizado pelo artista plástico
espanhol nos anos 70 , inclui serigrafias, fotografias, livros e 作 sença de crianças e adolescentes das comunidades vizi-
nhas dentro da Cidade Universitária suscitam o debate 


\title{
JORNAL DO CAMPUS
}

\section{Alunos da Letras acusam funcionários de superfaturar serviços de segurança}

\begin{abstract}
O delito teria ocorrido na contratação de vigilantes para a Feira Internacional do Livro, sendo seguido por outros atos ilícitos
Alunos do curso de Le- segurança contratados Paulo de Souza e Sérgio organizadores ao notarem bém teriam oferecido su- entrevistados não quisetras que participaram da para o evento $\quad$ Francisco de Lima. $\quad$ a diferença dos valores borno a eles para nãolevar ram se identificar com organização da Feira Inter- $\quad$ Dois dos estudantes, Os alunos relatam que combinados com os funci- adiante as denuncias. medo de perseguiçoes.

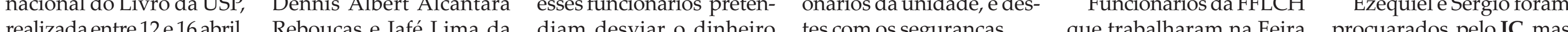
realizada enter acusam dois funcionários Silva, deram queixa no $93^{-}$destinado ao pagamento Osestudantes ainda afir- revelam que casos como não quiseram se pron superfaturar os serviços de dia 18, contra Ezequiel Isso foi evitado pelos pelos acusados, que tam- dos não são incomuns. O Carar. 3
\end{abstract}

\section{Governo Federal institui novo sistema de avaliação do ensino superior \\ OSistema Nacional de Avaliação do Ensino Su- perior (Sinaes) foi aprovado este mês pelo Presi- dente Luiz Inácio Lula da Silva. O novo método traz ainda o Exame Nacional de Desempenho de Estudantes (Enade) que deve substituir o Provão ainda este ano. \\ Entre as mudanças que o Sinaes trará, está a obrigatoriedade do exame apenas para uma amos- tra de alunos sorteados, para avaliar a evolução do aprendizado dos estudantes. \\ A periodicidade das avaliações também mudou será feita a cada três anos. Amedida visa a aumen- tar o número de cursos avaliados em comparação com o Provão. Além disso, outros aspectos, como a responsabilidade social, serão avaliados.}

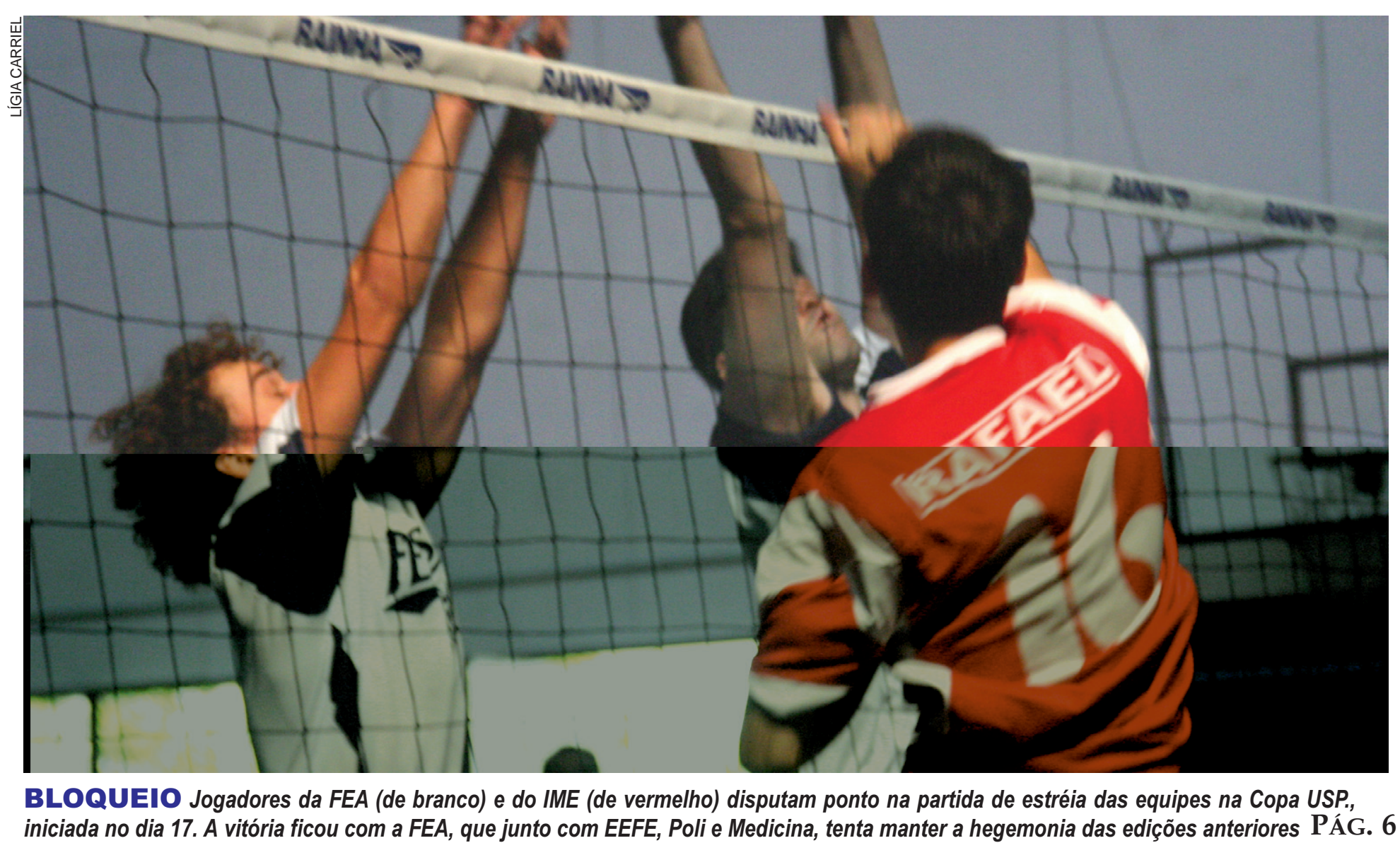

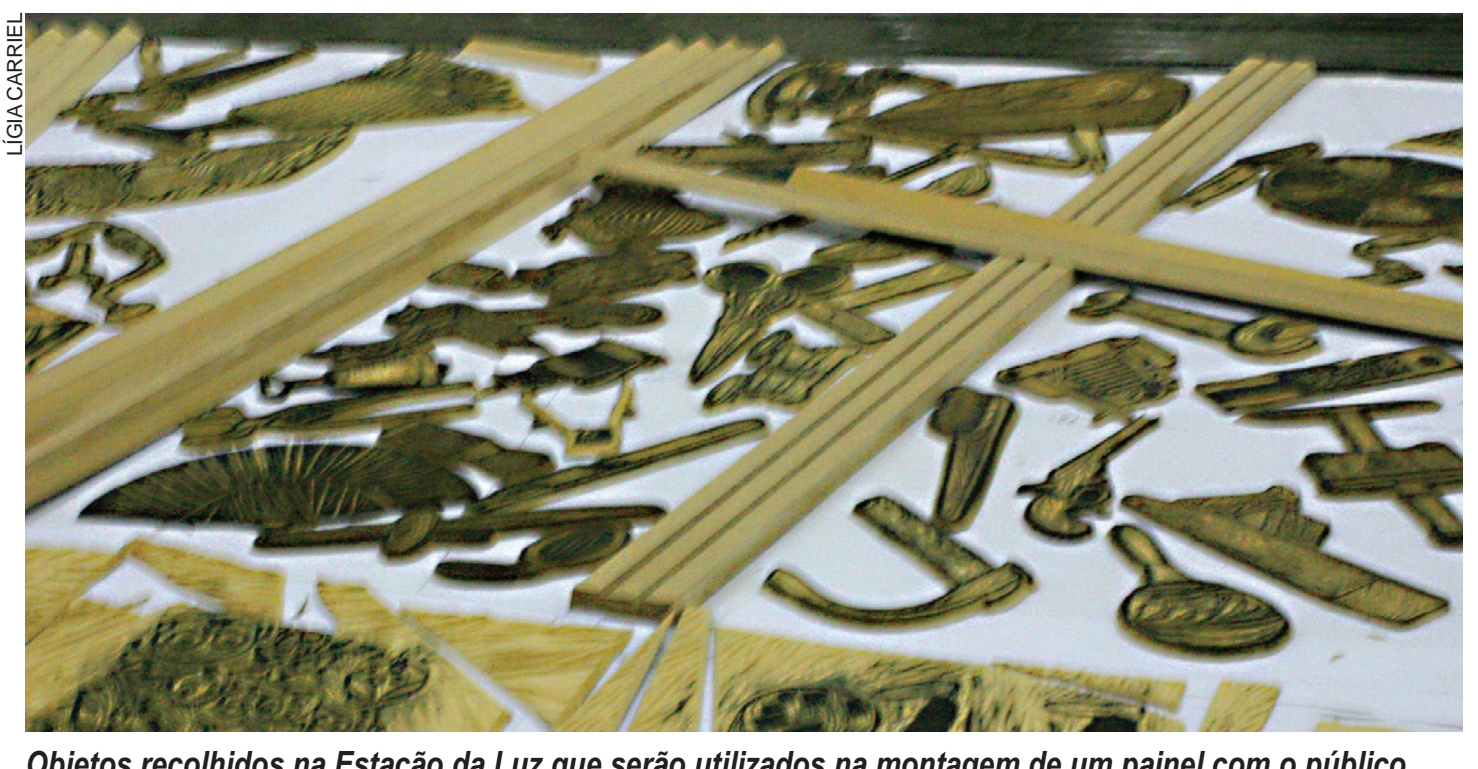

Projeto no MAC permite que público construa painel artístico

Com um conjunto de eles serão utilzados na Epopéins Paulistanas, objetos esquecidos na Es- construção de um painel. sediado no MAC, pretentação da Luz, a artista plás- A idéia é que qualquer de abrir espaço para a arte tica Maria Bonomi ideali- pessoa possa participar da popular e valorizá-la. zou um projeto no qual construção da obra.Assim,

\section{Televisão} exige novos formatos e programas

Esther Hamburger professora da ECA, comenta a situação atual da televisão brasileira. vivemos uma fase pobre em termos de experimentação na TV", diz PÁG. 7

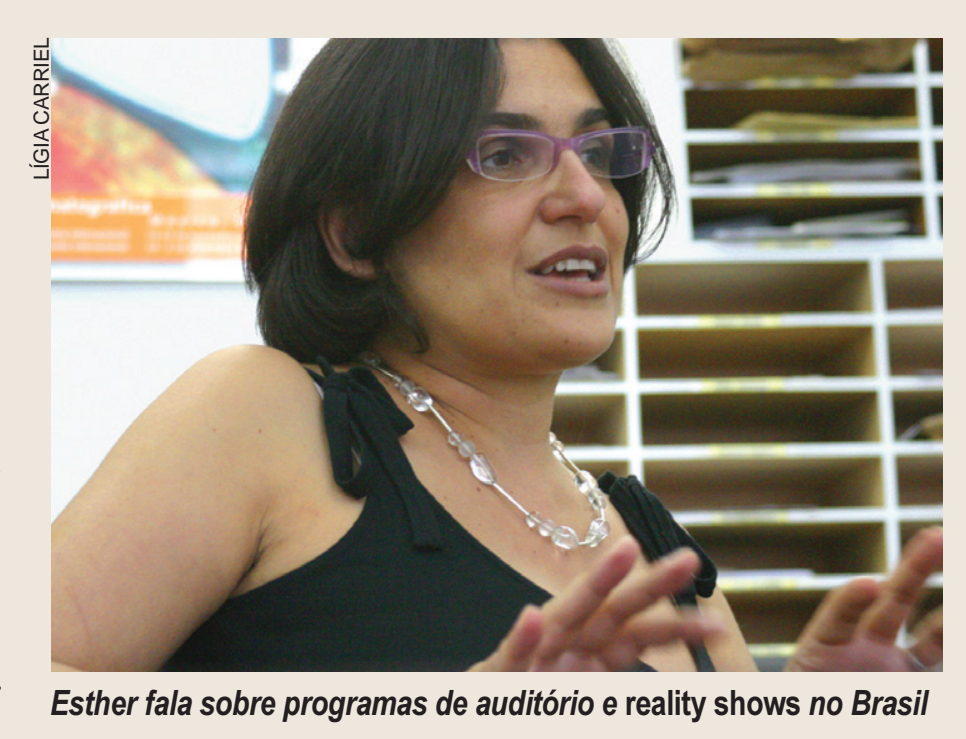

Ranqueamento amplia número de politécnicos indecisos

selecionados, desejam consistema de ranqueamento de acordo com suas notas tinuar seus estudos. daEscola Politecrica incen- do vestibular e dos dois pri- _Após o sistema], mais tivou einstitulu um clima - meiros anos docurso. alunos passaram a frecompetição permanenO sistema consiste seleção dos estudantes escola para uma das habi-
Projeto do CCE visa conectar unidades da Universidade Informação e Mobilidapassado, apresentou proposta de implementação (sem fio), que ajudaria na

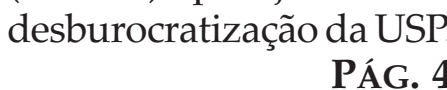

Filosofia e Sociais estão sem xerox e lanchonete

Ofechamento dos serviços no predio faz com que dade tanto para consegui cópias de textos, quanto para se alimentar. e, evento realizado dia 15
UNIVERSIDADE

Proposta cria novo cargo para os docentes da universidade

Grupo de professores coordenados por Zilda Iokoi, do
departamento de História, sugere uma nova função para acelerar a carreira dos docentes da USP. Trata-se do cargo de professor pleno, que teria os mesmos direitos do titular.
Claro!

As várias facetas dos jogos de azar, do vício à proibição

Medida provisória de fevereiro, proibindo jogos de azar no Brasil, levantou discussão acerca da ligação entre essas
atividades e o crime organizado. Claro! analisa o histórico de glamour e ilegalidade da indústria que movimenta bilhões.
SUPLEMENTO
O Instituto de Psicolo- qüentar as sessões de atengia mantém um programa dimento", conta Ingrid podrigues, uma das profise

Painel do CAMpus

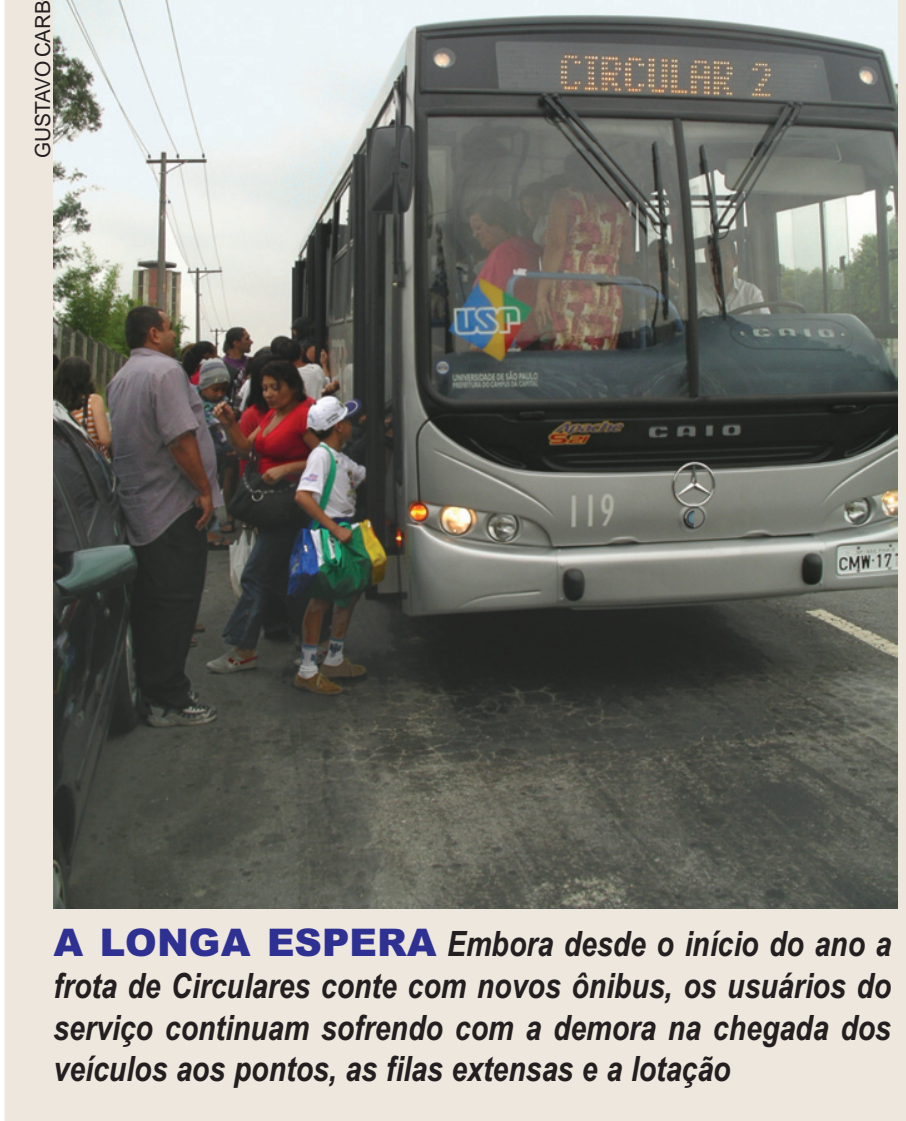

DEBATE

O desequilíbrio entre ensino, pesquisa e extensão na USP

O tripé que incorpora a idéia da universidade pública anda manco. Para muitos professores, o ensino e a pesquisa
caminham juntos, mas poucos conseguem conciliar essa atividades à extensão universitária. 


\section{JORNAL DO CAMPUS}

Escola de Comunicações e Artes - Universidade de São Paulo - 4 a 17 de junho de 2004 - Número 285, Ano 22

\section{USP pára a espera de reajuste salarial}
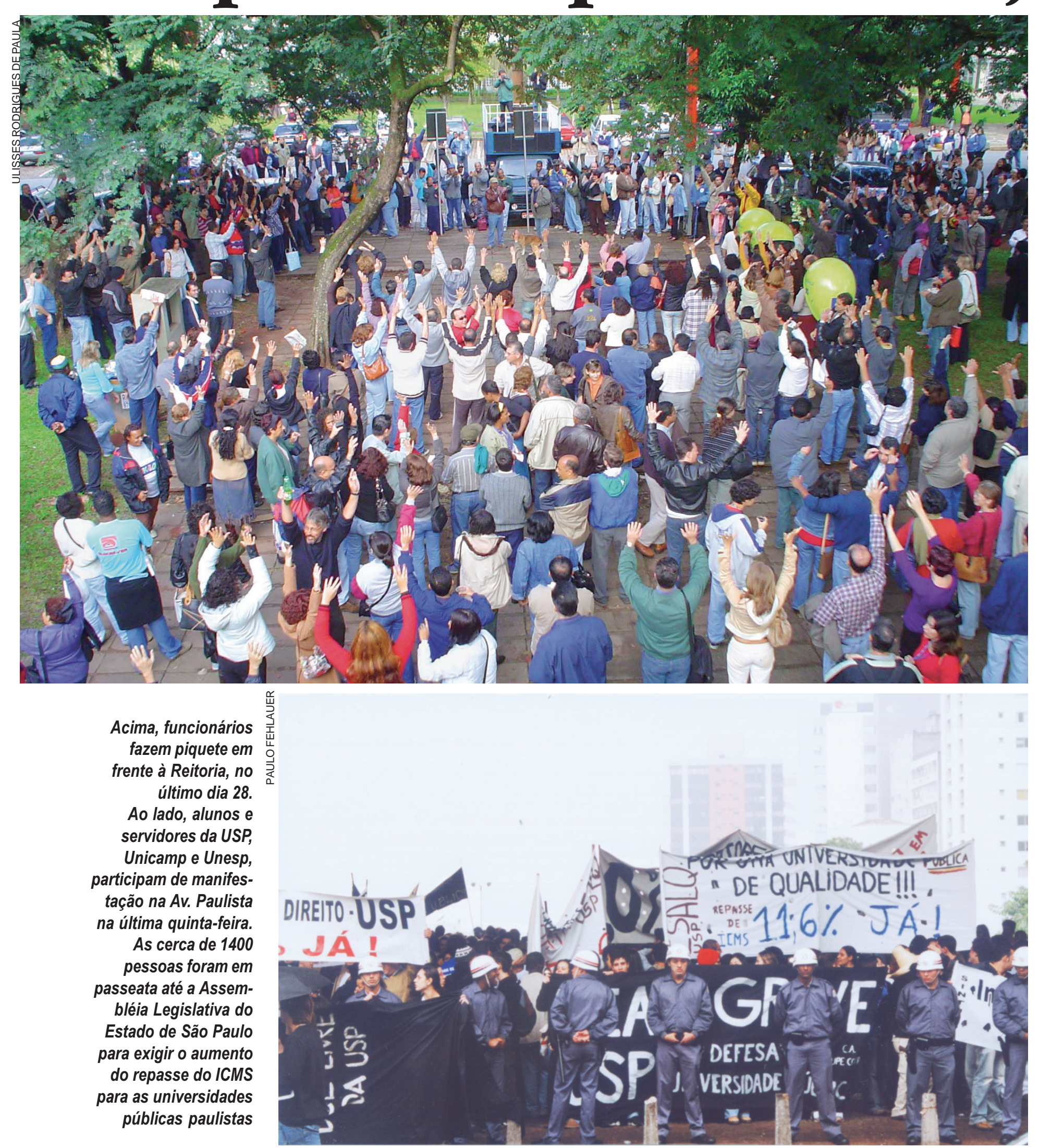

Carrinhos de rolimã descem Rua do Matão em GP da Poli

O36 GP Poli NSK, a tradicional corrida de carrinhos de rolimã, aconteceu dia 29 de maio. Os competidores desceram a Rua do depois de algumas curvas e lombadas, muitos ficaram pelo caminho. Mesmo são foi garantida. PÁG. 6

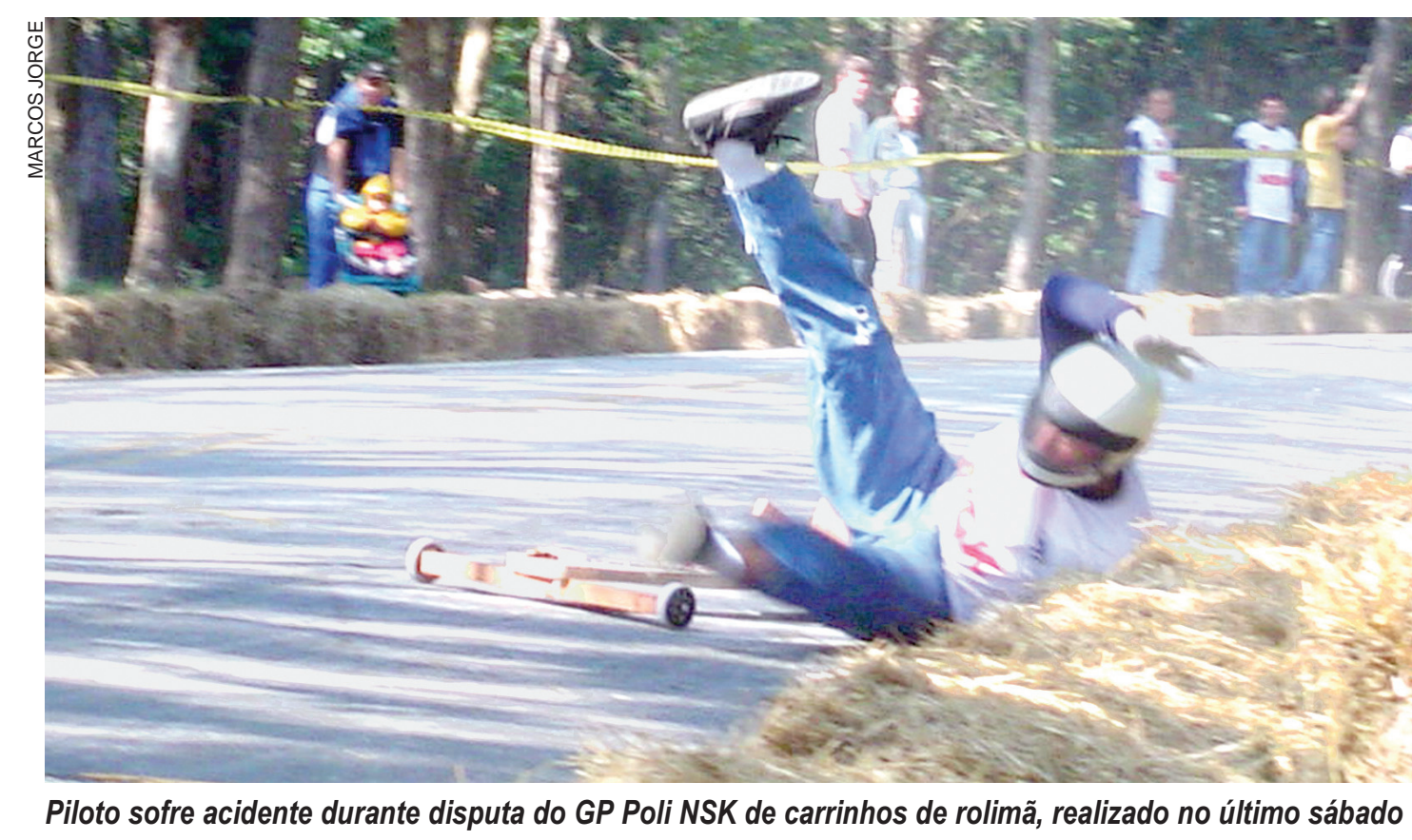

Painel do Campus

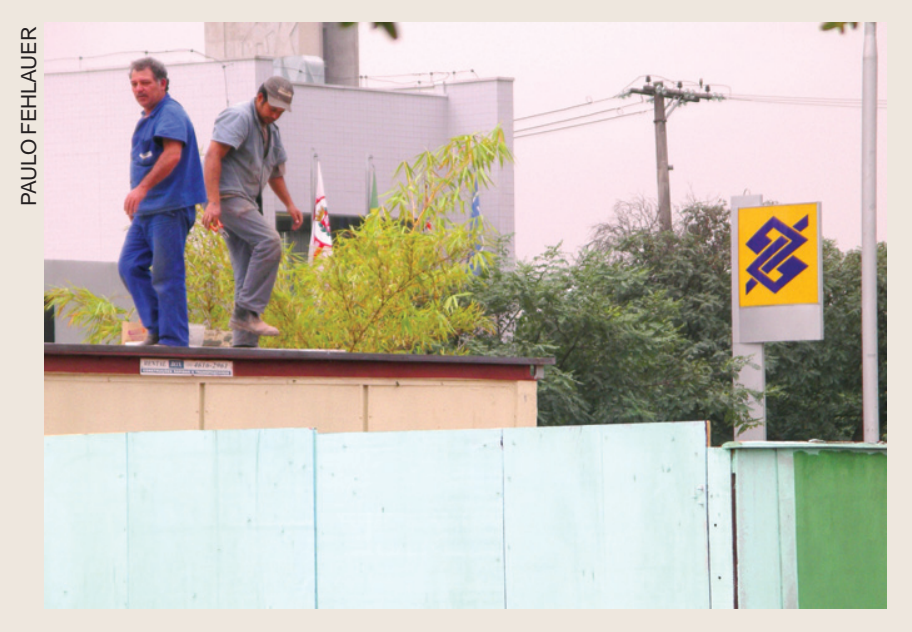

EM OBRAS Os tapumes no estacionamento dos bancos, na Av. Luciano Guallberto, escondem a construção de ou-
tra agência no espaço - futura instalação do Banco Real

Debate

Opinióes sobre greve dividem alunos da universidade

Á medida que a greve cresce, aumentam as discussões sobre
sua legitimidade, organização e desenvolvimento. Estudantes paraliscã e articulam opiniñ se sobre tema.
Alunos propõem melhorias para sistema de circulares

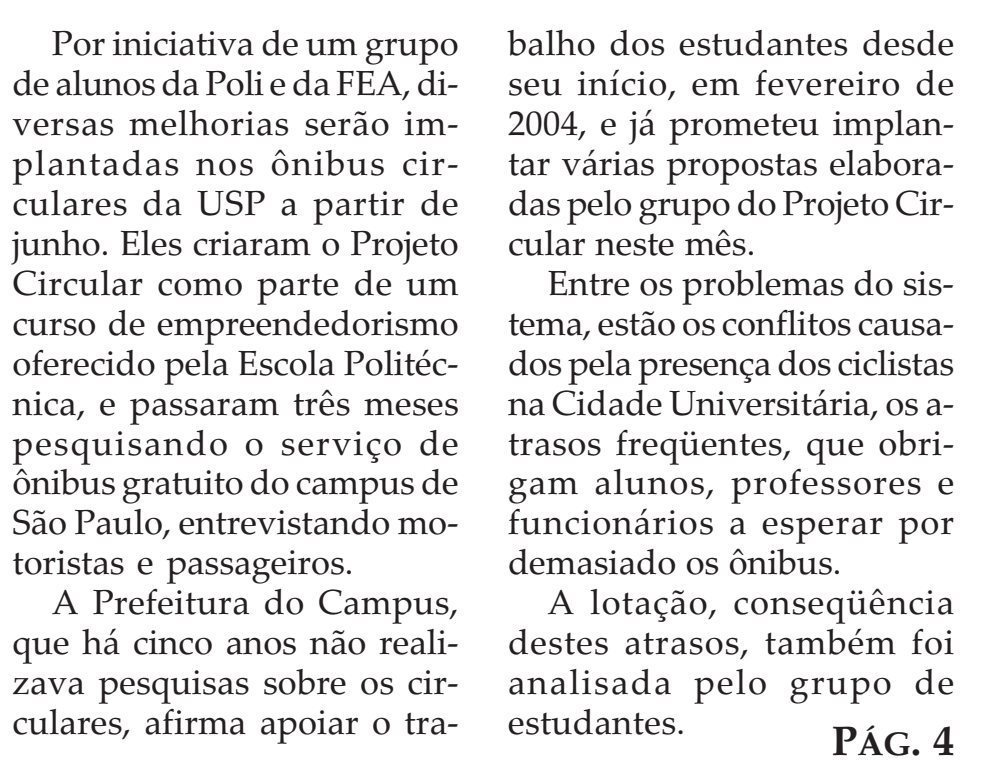

UNIVERSIDADE

Manifestantes invadem aulas de cursos pagos em protesto

Cerca de 50 alunos interromperam aulas e ocuparam classes
utilizadas pelos cursos pagos de MBA da FEA e da Poli, nos utilizadas pelos cursos pagos de MBA da FEA e da Poli, nos
últimos dias 26 e 27 . Comandados pelo DCE, intencionavam ampliar a discussão sobre as fundações na USP PÁG.
- Funcionários e professores exigem aumento de $16 \%$ e maior repasse do ICMS

- Cruesp mantém 0\% e marca nova reunião para a próxima segunda-feira

- Estudantes se reúnem em assembléia e decidem apoiar o movimento grevista

Funcionários e professo- Universidades Estaduais res das três universidades Paulistas (Cruesp) . públicas estaduais de São A última assembléia da Paulo estão em greve des- Associação dos Docentes de o dia 27 de maio. Ape- da USP (Adusp), dia 31, . essa é, segundo o Sindica- professores, número supe USP (Sirabahnadores da rior aos 50 docentes preUSP (Sintusp), a greve de sentes na primeira reunião doscine mais rápido que deliberou pela greve. dos últimos dez anos. A Eles defendem uma auprincipal explicaçao estaria mentodorepasse doICMS no inedito $0 \%$ de reajuste, e das verbas para a educaferecido três vezes pelo ção em todos os níveis.

Cursinho da Poli é acusado de esquecer inclusão social

A gestão do Grêmio da clusão socil", diz tayd P a atual política de expan- mio e membro do Conseão do Cursinho da Poli, lho Curador do cursinho nem com o aumento da Ela reclama de falta de sua taxa de manutenção. transparência nas contas OGrêmio acusa o cursi- envolvendo o cursinho. nho de adotar políticas que Segundo o diretor exenão levam em conta a idéia cutivo, Fábio Sato, todas as original por tras de sua cri- contas podem ser es şo a súve com cin $\begin{array}{ll}\text { so acessivel a comunida- } & \text { a expansão e o aumento da } \\ \text { des carentes. } & \text { mensalidade não fizeram }\end{array}$ Em 2003, a mensalidade com que o cursinho deido curso extensivo matu- xasse de oferecer bolsas tino de bio/exatas era $\mathrm{R} \$$ para a comunidade caren167. Este ano, aumentou te, após análise sociopara R\$265. Com 17 mil econômica. Sato ainda cita vagas, o cursinho tem $6 \mathrm{mil}$ parcerias com as prefeitualunos frequentando as ras de São Paulo, que en“O cursinho está fugin- caminha jovense paga pa"O cursinho está fugin- te da bolsa integral. do da sua proposta de in- PÁG. 5

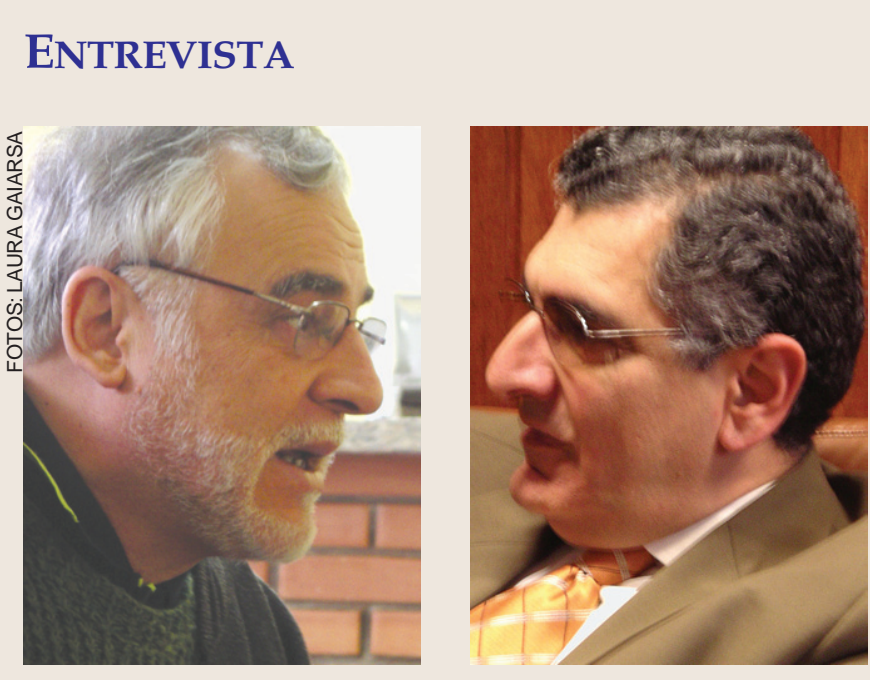

Os professores Osvaldo Coggiola (esq.) V Vahan Agopyan (dir.)

Professores expõem suas posições frente à greve

$$
\begin{aligned}
& \text { Osvaldo Coggiola, da História, e Vahan } \\
& \text { Agopyan, da Poli, falam sobre o movimento de } \\
& \text { greve e a influência deste sobre o cotidiano e o fu- } \\
& \text { turo da universidade. Apesar das diferenças de opi- } \\
& \text { nião, ambos concordam que é preciso lutar con- } \\
& \text { tra o sucateamento do ensino público superior. } \\
& \text { PáG. } 7
\end{aligned}
$$

\section{Cultura}

Palestras mantêm estudantes ocupados durante paralisação O II ciclo de palestras Cultura de Greve, organizado pelo Departamento de Artes Plásticas da ECA, estimula a discussão participação de alunos e professores da FAU. $\quad$ PÁG. 8 


\section{JORNAL DO CAMPUS}

\section{Negociadores mantêm impasse e greve segue com adesão parcial de alunos}

- Cruesp oferece reajuste em duas etapas e espera contraproposta do Fórum das Seis

- Assembléia Geral dos Estudantes decide pela greve e acrescenta reivindicações

- Atos de protesto continuam enquanto movimento dá primeiros sinais de desgaste
DiREITO DE RESPOSTA De acordo com a Lei Federal N. 5250 - Lei de Informação - de 9 de fevereiro de 1967

\section{Uso do Campo é legal e}

\section{financia projetos sociais}

Entidade centenária erroneamente acusada de usar espaço público de forma indevida
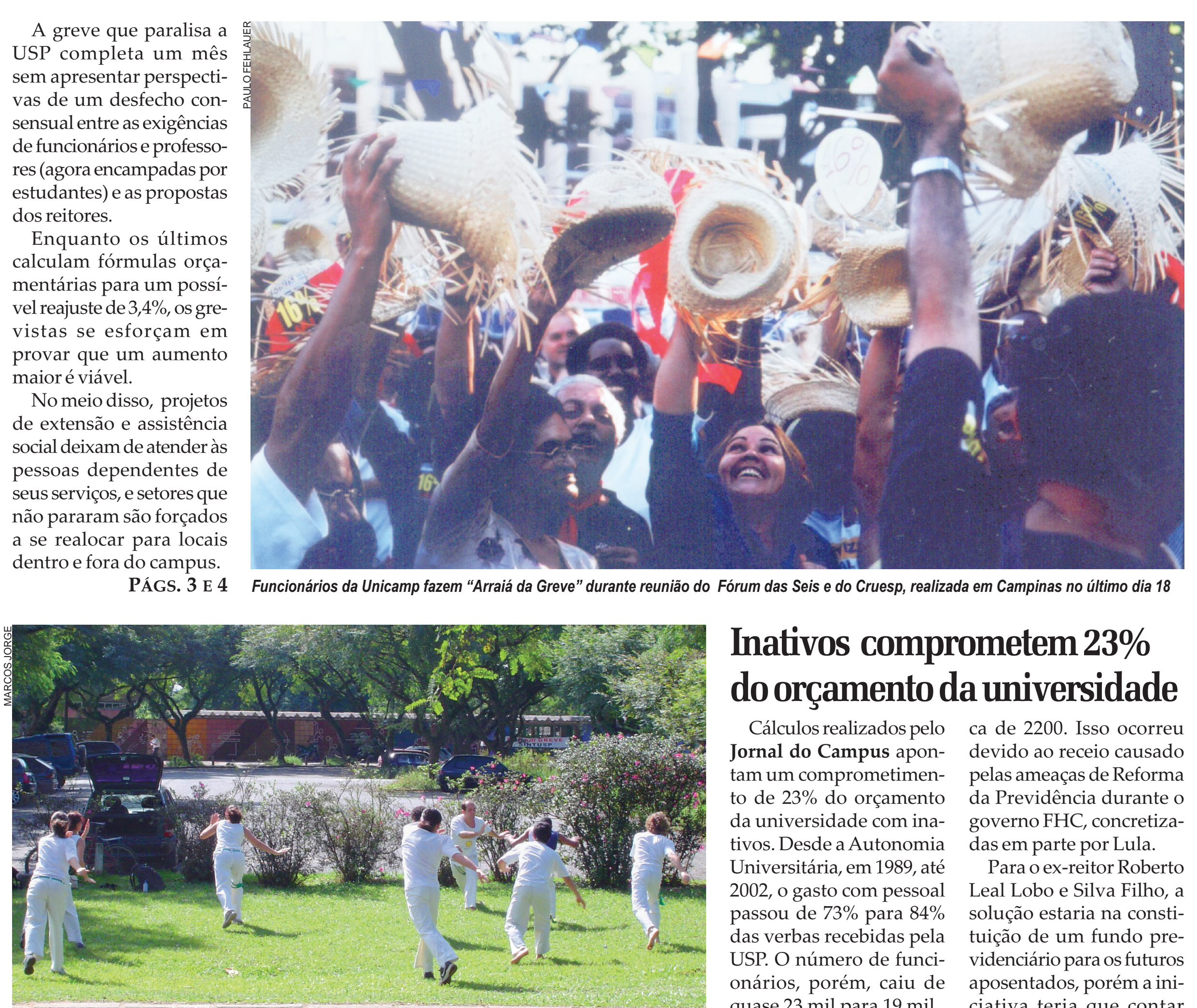

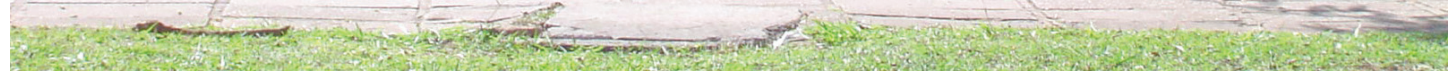
Capoeiristas praticam em gramado em frente ao Cepeusp, que está fechado durante a semana devido à greve

Inativos comprometem $23 \%$ do orçamento da universidade Cálculos realizados pelo ca de 2200. Isso ocorreu
Jornal do Campus apon-
devido ao receio causado $\begin{array}{ll}\text { Jornal do Campus apon- } & \text { devido ao receio causado } \\ \text { tam um comprometimen- } & \text { pelas ameaças de Reforma }\end{array}$ to de $23 \%$ do orçamento da Previdência durante o da universidade com ina- governo FHC, concretiza-
tivos. Desde autonomia
das em parte por Lula. tivos. Desde a Autonomia das em parte por Lula. Universitária, em 1989, até Para o ex-reitor Roberto $\begin{array}{ll}\text { 2002, o gasto com pessoal } & \text { Leal Lobo e Silva Filho, a } \\ \text { passou de } 73 \% \text { para } 84 \% & \text { solucão estaria na consti- }\end{array}$ passou de $73 \%$ para $84 \%$ solução estaria na constidas verbas recebidas pela tuição de um fundo pre-
USP. O número de funci- videnciário para os futuro onários, porém, caiu de aposentados, porém a iniquase 23 mil para 19 mil. ciativa teria que contar No período, o número com o apoio financeiro inide professores aposenta-
dos saltou de 966 para cer-
ENTREVISTA

'Problemas de São Paulo pedem compromisso geral'

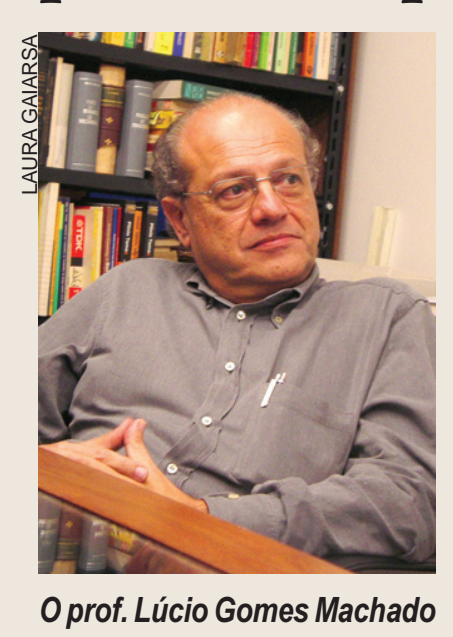

O professor da FAU comenta o planejamento urbano e a reorganização pela qual passa a arquiteto diz que solucões para os problemas da metrópole são possíveis, desde que haja compromisso de toda a população. PÁG. 7

\section{- Debate}

Decisão de greve estudantil não encontra unanimidade

- Alunos dão sua opinião sobre a greve estudantil decidida en
assembléia geral realizada dia 14. Ás exigências de reajuste salarial e aumento do repasse do
acrescentaram novas reivindicaçōes.

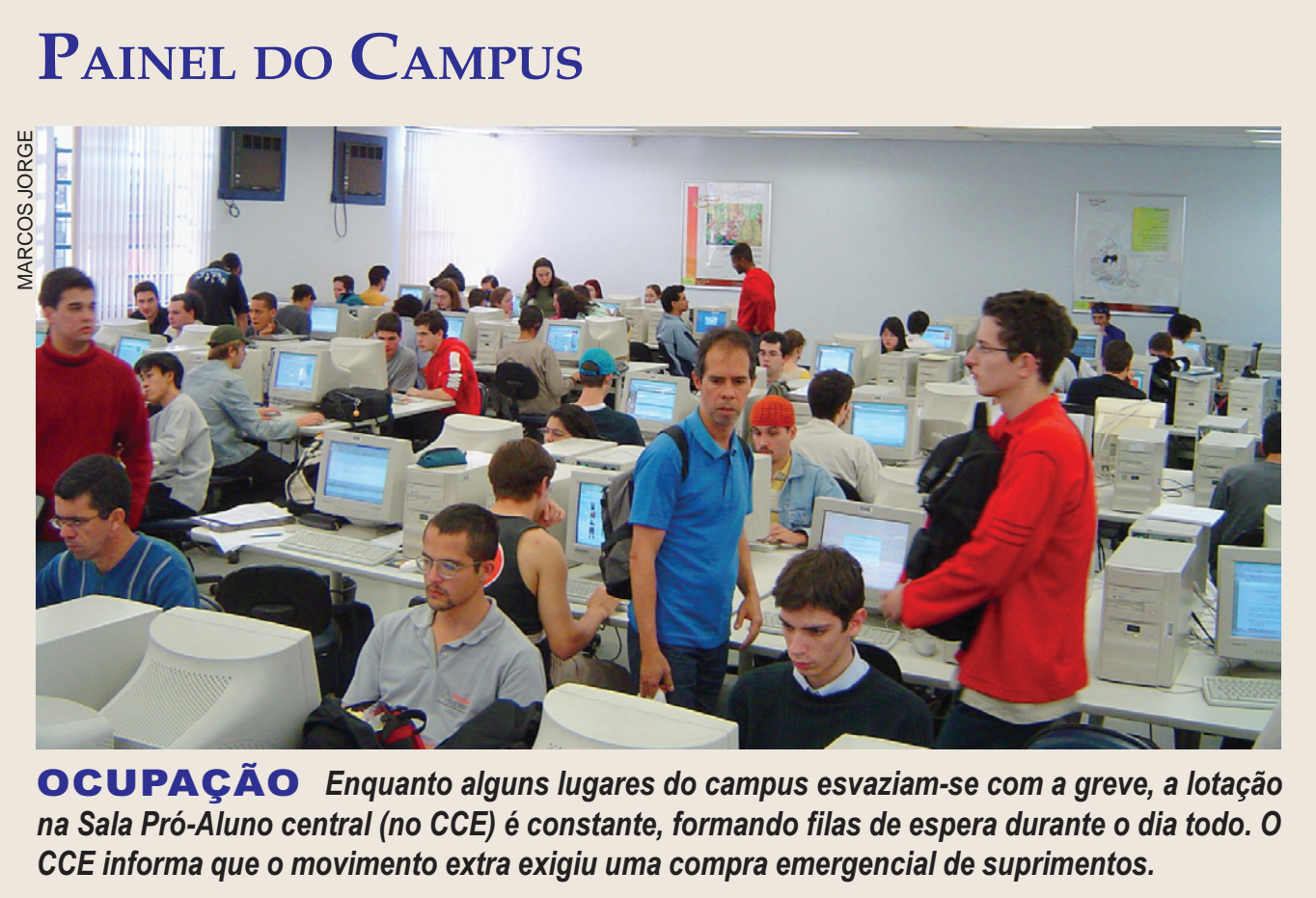

Pesquisa faz radiografia do esporte na universidade

Levantamento inédito do Jornal do Campus aponta uma preferência de
$18 \%$ dos atletas da USP pelo futsal, líder das estatisticas ate mesmo entre as meninas. Os dados mostram também uma maio participação das atléticas tradicionais nos esportes individuais e o pólo aquático como a modalidade menos procurada.
UNIVERSIDADE

Medidas impostas às bolsas afetam pesquisas de alunos

A diminuição dos prazos para a apresentação dos trabalhos que pós-graduacão e a defasagem das bolsas são as principais receberam o pagamento de maio com 20 dias de atraso.
CUlTURA

Eventos culturais seguem ativos durante paralisação

Balanço mostra que, apesar da expressiva adesão à greve, metade dos museus da USP mantém seu funcionamento Artes Cênicas, que continua a ser apresentada. 